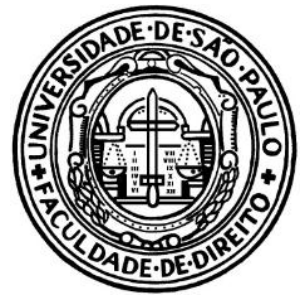

JULIANA CRISTINE DINIZ CAMPOS

TESE DE DOUTORADO

ORIENTADOR: MARCELO DA COSTA PINTO NEVES

NOMOGÊNESE E PODER CONSTITUINTE: FUNDAMENTAÇÃO RACIONAL E A LEGITIMIDADE DEMOCRÁTICA DA NORMA CONSTITUCIONAL

São Paulo, SP

Janeiro de 2013 
JULIANA CRISTINE DINIZ CAMPOS

TESE DE DOUTORADO

NOMOGÊNESE E PODER CONSTITUINTE: FUNDAMENTAÇÃO RACIONAL E A LEGITIMIDADE DEMOCRÁTICA DA NORMA CONSTITUCIONAL

Tese apresentada perante a banca examinadora na Universidade de São Paulo como requisito parcial para obtenção do grau de Doutor em Direito, na área de concentração em Direito do Estado, tendo como orientador o professor Doutor Marcelo da Costa Pinto Neves.

São Paulo, SP

Janeiro de 2013 
NOMOGÊNESE E PODER CONSTITUINTE: FUNDAMENTAÇÃO RACIONAL E A LEGITIMIDADE DEMOCRÁTICA DA NORMA CONSTITUCIONAL

Aprovada em:

Banca Examinadora:

Prof. Dr. Marcelo da Costa Pinto Neves (Orientador)

Examinador :

Instituição:

Examinador:

Instituição:

Examinador:

Instituição:

Examinador:

Instituição: 


\section{A S. Castor}

Aos meus pais, mais uma vez, $e$ sempre 


\section{AGRADECIMENTOS}

Este trabalho não teria sido possível sem o auxílio silencioso e diário de meu marido, sem a confiança atenta de meus pais, sem a companhia dos meus amigos queridos nos momentos de descanso e de riso, sem a ajuda dos colegas de pós-graduação que fiz quando cheguei a São Paulo e que de modo inestimável me ajudaram a seguir em frente durante o cumprimento dos créditos, o exame de qualificação, o depósito do trabalho final. Meu especial agradecimento a Allison Sellaro, Paulo Maluf, Raquel Machado, Ramon Negócio, Márcio Diniz, Danyele Melo, Maria Vital da Rocha, Felipe Albuquerque, Paulo Carvalho e Raul Nepomuceno pelo apoio durante a produção do texto. Meu agradecimento póstumo ao Professor Dr. Agerson Tabosa, inspiração acadêmica que obteve o grau de Doutor na Universidade de São Paulo e cujo valioso acervo bibliográfico foi gentilmente disponibilizado para pesquisa. Também agradeço ao pequeno Bob, pela sua candura e companhia. 
O tempo é minha matéria, o tempo presente, os homens presentes,

a vida presente.

Carlos Drummond de Andrade, Mãos Dadas 


\section{RESUMO}

DINIZ CAMPOS, Juliana Cristine. Nomogênese e poder constituinte: fundamentação racional e a legitimidade democrática da norma constitucional. 2013. 239f. Tese (Doutorado). Faculdade de Direito, Universidade de São Paulo, São Paulo, 2013.

O poder constituinte, tal como entendido pela teoria constitucionalista clássica, é definido como poder bruto, original, ilimitado e incondicionado, a partir do qual nasce o Estado e, por consequência, a ordem jurídica. Esse poder, definido como supraestatal, não encontra limites no direito e, nas concepções democráticas, é titularizado pelo povo soberano. Essa concepção teórica passa por uma releitura no trabalho, a fim de se definir o poder constituinte como poder comunicativo criador da norma constitucional, de aparição episódica, por meio do qual é possível filtrar os argumentos morais, ético-políticos e estratégicos expostos pelos cidadãos na esfera pública democrática, representativos de um modo de vida compartilhado que se impõe politicamente. De acordo com a releitura apresentada, os postulados da ilimitação material e da incondicionalidade do poder constituinte não se sustentam em face do paradigma da racionalidade comunicativa e dialogal. Na qualidade de momento de fundação e fundamentação da ordem constitucional, o poder constituinte precisa respeitar direitos pressupostos, garantidores da autonomia individual, e institucionalizar os procedimentos discursivos que viabilizam a reprodução do direito legítimo. Entendido como processo extraordinário, no qual os interesses e os valores permanecem latentes na sociedade, o exercício do poder constituinte representa um momento único para análise do discurso de fundamentação normativa, objeto central da tese. Associando-se fundamentação normativa com legitimidade política, nos termos da teoria democrática exposta por Jürgen Habermas, conclui-se que o cerne da legitimidade das ordens estatais organizadas democraticamente é a institucionalização de uma ordem jurídica fundamentada discursivamente por intermédio de um procedimento de deliberação pública, no qual todos os potenciais atingidos pela norma possam exprimir o seu assentimento. O poder constituinte, ao estruturar o estado, garante que o processo de formação da vontade e da opinião pública se estabilize e o consenso seja alcançado.

Palavras-chave: poder constituinte; limites; fundamentação normativa; ética do discurso; teoria da democracia; procedimentalismo. 


\begin{abstract}
DINIZ CAMPOS, Juliana Cristine. Nomogenesis and constituent power: rational grounds and democratic legitimacy of the constitutional norm. 2013. 239p. Thesis (Doctoral). School of Law, Universidade de São Paulo, São Paulo, 2013.
\end{abstract}

Constituent power, based on classical constitutional theory, is defined as raw, original, limitless and unconditional power, from which the state and, consequently, legal order are born. Such power, defined as supranational, knows no boundaries in the law and according to democratic notions it is held by the sovereign people. This thesis reexamines that theoretical conception in order to define constituent power as a communicative power which creates constitutional norm; it appears occasionally and it allows for a selection of moral, ethical-political and strategic arguments introduced by citizens in the public democratic sphere which represent a shared way of life that imposes itself politically. According to this reexamination, postulates of constituent power's material illimitation and unconditionality cannot resist to the paradigm of communicative and dialogical rationality. As the founding moment and grounds of constitutional order, constituent power must respect presupposed rights which guarantee individual autonomy and institutionalize discursive procedures which enable the reproduction of legitimate law. Understood as an extraordinary process in which interests and values remain latent in society, exercise of constituent power represents a unique moment to analyze the normative grounds discourse, the core issue of this thesis. Combining normative grounds and political legitimacy, in the terms of the democratic theory introduced by Jürgen Habermas, the conclusion is that the essence of legitimacy of democratically-organized state orders is the institutionalization of a legal order based discursively through a process of public deliberation, where all individuals potentially affected by the norm may express their consent. By structuring the state, constituting power ensures that the public will and opinion formation process will become stable and consensus will be reached.

Keywords: constituent power; limits; normative grounds; discourse ethics; theory of democracy; proceduralism. 


\section{RÉSUMÉ}

DINIZ CAMPOS, Juliana Cristine. La Nomogénèse et le pouvoir constituant: le fondement rationnel et la légitimité démocratique de la norme constitutionnelle. 2013. 239f. Thèse de Doctorat. Faculdade de Direito, Universidade de São Paulo, São Paulo, 2013.

Le pouvoir constituant, compris depuis la théorie constitutionnaliste classique, est défini comme pouvoir brut, originel, illimité et inconditionné, à partir de quel l'État est né et, par conséquence, l'ordre juridique. Ce pouvoir, défini comme supranationale, ne rencontre pas de délimitations dans le droit et, dans les conceptions démocratiques, est titularisé par le peuple souverain. Cette conception théorique passe ici par une nouvelle interprétation pour définir le pouvoir constituant comme un pouvoir communicatif, créateur de la norme constitutionnelle, d'apparition épisodique, vers laquelle il est possible raffiner les arguments morales, éthiques, politiques et stratégiques exposés par les citoyens à la sphère publique démocratique, représentatifs d'un mode de vie partagé qui s'impose politiquement. Selon la nouvelle interprétation, les présomptions de l'illimitation matérielle et de l'inconditionnalité du pouvoir constituant ne se soutiennent pas face au paradigme de la rationalité communicatif et dialogal. En ce qui concerne le moment de la fondation et le fondement de l'ordre constitutionnel, le pouvoir constituant doit respecter les droits présumés, garants de l'autonomie individuelle, et institutionnaliser les procédures discursifs qui viabilisent la reproduction du droit légitime. Conçu comme procès extraordinaire, sur lequel les intérêts et les valeurs restent latents dans la société, l'exercice $\mathrm{du}$ pouvoir constituant représente un moment unique pour l'analyse du discours de fondement normatif, objet central de la thèse. En s'associant le fondement normatif avec la légitimité politique, sur la théorie démocratique exposée par Jürgen Habermas, il est possible accomplir que le cœur de la légitimité des ordres gouvernementales démocratiquement organisées est l'institutionnalisation d'une ordre juridique motivée discursivement au moyen d'un procédure de délibération publique, dans lequel tous les potentiels accomplis par la norme puissent exprimer son assentiment. Le pouvoir constituant, en structurant l'état, certifie que le procès de formation de la volonté et de la opinion publique se stabilise et le consensus soit réussi.

Mots clés: pouvoir constituant; délimitations; fondement normatif; éthique du discours; théorie de la démocratie; procéduralisme. 


\section{SUMÁRIO}

1 Introdução.

\section{PARTE I - O PODER CONSTITUINTE DO LIBERALISMO CLÁSSICO}

2 Das origens do poder constituinte: o constitucionalismo na

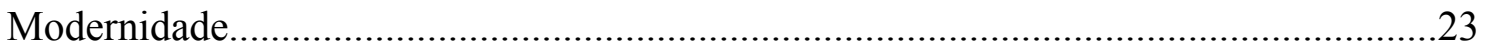

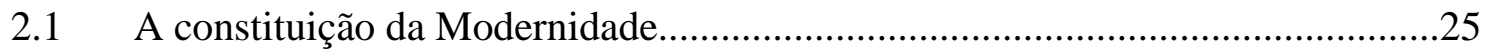

2.2 Do conceito de poder constituinte e sua contextualização histórica....................29

2.2.1 O contratualismo europeu e as primeiras teorizações sobre a legitimação do poder

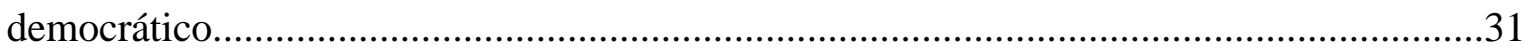

2.3 O terceiro estado e o poder constituinte: a teoria de Sieyès e sua recepção pela doutrina constitucionalista. .39

3 A teoria clássica do poder constituinte

3.1 Definições de poder constituinte.

3.1.1 O poder constituinte em Georges Burdeau e Carré de Malberg.

3.1.2 O poder constituinte em Jorge Miranda e Joaquim Canotilho.

3.1.3 Doutrina brasileira. . .64

3.1.4. O poder constituinte na teoria constitucional de Carl Schmitt. .72 
3.2 Da natureza do poder constituinte.

3.3 Classificação do poder constituinte. 84

3.4 Insuficiências da teoria clássica .89

3.5 A teoria clássica e suas releituras .92

\section{PARTE II - O PODER CONSTITUINTE DO ESTADO DEMOCRÁTICO DE DIREITO E SEUS PRESSUPOSTOS FILOSÓFICOS}

4 A reviravolta linguístico-pragmática e a mudança de paradigma na racionalidade jurídica.

4.1 O paradigma da razão monológica: a contribuição de Kant. 106

4.2 O paradigma da razão comunicativa

4.3 Razão comunicativa e alternativas à teoria clássica do poder constituinte. 116

5 A fundamentação da ética pelo discurso e o modelo procedimental de democracia.

5.1 Da possibilidade de uma fundamentação racional para as normas do agir humano: a Ética do Discurso. 124

5.1.1 A racionalidade instrumental e a negação da fundamentação da ética. 127

5.2 A racionalidade comunicativa e o resgate da ética pelo discurso. 133

5.2.1 O argumento apeliano pela possibilidade de uma fundamentação 139 
5.3 Teoria crítica da sociedade moderna e razão comunicativa

6 Direito e democracia em Habermas: A legitimação do direito positivo pelo consenso

6.2. Princípio moral e princípio democrático: legitimidade e o sistema de direitos

6.2.1 Direito à maior medida possível de iguais liberdades subjetivas de ação 160

6.2.2 Direitos à postulação judicial de direitos. 160

6.2.3 Direitos decorrentes do status de membro de uma sociedade política

6.2.4 Direitos à participação no processo de formação da vontade política

6.2.5 Direitos a condições de vida garantidas social, técnica e ecologicamente.

6.3. O conceito de Esfera Pública.

6.4. O Processo de Formação da Vontade e da Opinião Política

6.5 A Contribuição Teórica Habermasiana e a Teoria da Constituição

7 A Teoria do Poder Constituinte Democrático 186

7.1 A proposta teórica: delineamentos gerais 190

7.2 Os postulados do poder constituinte democrático 194

7.2.1 Fundamentos 194

7.2.2 Limitações 199

7.2.2.1 Autonomia individual. 202 
7.2.2.4 Estabilidade da esfera pública pluralista e inclusiva...........................................207

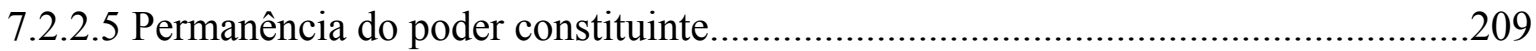

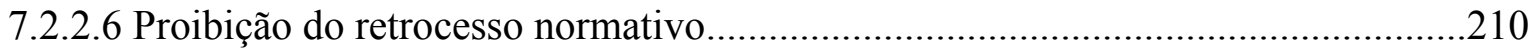

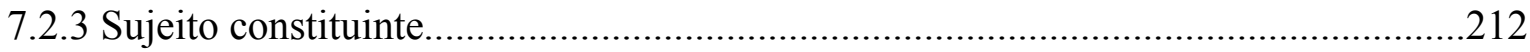

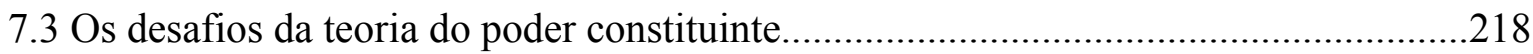

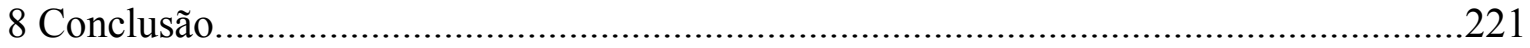

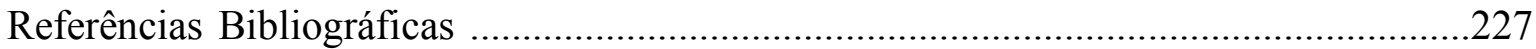




\section{INTRODUÇÃO}

A constituição é o documento político que define a identidade jurídica de um povo, expondo seu modelo de organização institucional, o modo de exercício do poder em face dos interesses e antagonismos existentes, os direitos e deveres básicos dos indivíduos, o modo de ser do Estado e os limites da relação entre este e a sociedade civil.

A importância da constituição para a teoria do direito se constrói desde o advento do Estado Liberal, quando as cartas constitucionais, assumindo a função de edificar a ordem jurídica, são identificadas com a proteção dos direitos individuais e com o resultado de uma revolução social, política e ideológica que provocou a secularização do poder e a consolidação da economia capitalista de mercado.

A constituição se mostra importante não apenas por formular as normas básicas e as instituições concernentes a um sistema político e econômico, mas por definir o equilíbrio de forças entre estado e sociedade, além de ostentar um significado simbólico e ideológico poderoso ao proteger valores partilhados e princípios de uma comunidade política. A constituição reúne, pois, uma amálgama única de cultura, poder e política ${ }^{1}$, que justifica o rápido desenvolvimento do edifício teórico do Direito Constitucional ao longo do século XX.

É inegável, portanto, que a compreensão das cartas constitucionais, o estudo de sua estrutura, de sua interpretação e de sua aplicação conduzem o estudioso do Direito à compreensão do próprio sistema de normas, que se desenvolve a partir dos procedimentos manifestos na constituição. O Direito Constitucional assume, nessa perspectiva, um papel integrador do ordenamento jurídico, compreendido como uma ordem racional e lógica fundamentada nos dispositivos positivados na carta constitucional.

Sendo a norma constitucional, portanto, o ponto de partida da cadeia de fundamentação da ordem jurídica, é indispensável que pretenda validade, não estritamente formal, mas igualmente material: uma norma válida é condição de uma ordem legítima. Isso porque o poder legítimo não se faz sem uma exigência de justificação. É dizer, o

\footnotetext{
${ }^{1}$ NOLTE, Detlef; SCHILLING-VACAFLOR, Almut. New Constitutionalism in Latin America: Promises and Practices. Surrey: Ashgate, 2012.
} 
direito, justificado, transforma-se em autoridade, entendida esta como o "direito de ter poder". O direito, para valer como ordem autônoma e impositiva, depende da autoridade de seu conteúdo normativo ${ }^{2}$. Mas quais são, então, os caminhos da validade da norma constitucional?

Neste trabalho, busca-se investigar de que forma as normas constitucionais podem ser fundamentadas, de modo que sua exigibilidade se apresente como um imperativo racional ao agir dos sujeitos de direitos. A força vinculante da norma constitucional não é, portanto, compreendida exclusivamente como uma consequência do processo de positivação normativa. Sua exigibilidade não advém, a princípio, da força de sua imposição pelo Estado ${ }^{3}$ : a positividade do Direito não pode fundar-se somente na contingência de decisões arbitrárias, sem correr o risco de perder seu poder de integração social $^{4}$. A rigor, tem-se que a positivação deve ser o resultado da exigibilidade racional de um comando normativo e, assim sendo, quais devem ser os critérios para que determinada norma seja considerada justificada, exigível e, portanto, passível de ser positivada?

O tema se insere dentro da teoria da constituição originada do constitucionalismo ocidental moderno, mas sua relevância permeia a teoria do direito como um todo. Isso porque, sendo a constituição a norma responsável pelo fechamento operativo do direito, a partir da qual as demais normas podem encontrar seu fundamento de validade tanto material como formal, renunciar a uma fundamentação da norma-mãe é renunciar à fundamentação do sistema em sua integralidade. A função que a carta constitucional exerce é, para além da organização dos procedimentos e das instituições estatais, uma função racionalizante - ela é capaz de oferecer as motivações que tornam ações/omissões, procedimentos e instituições socialmente desejáveis.

A fundamentação da norma constitucional não pode se restringir ao aspecto puramente formal-sistêmico ${ }^{5}$, segundo o qual uma norma é válida na medida em que obedece ao procedimento ditado por uma norma superior, sem lhe contrariar o conteúdo ou suas vedações. Esse critério, definido como Hans Kelsen ${ }^{6}$ como o parâmetro de validade

\footnotetext{
${ }^{2}$ SALDANHA, Nelson. O Poder Constituinte. São Paulo: Revista dos Tribunais, 1986, pg. 35.

3 Cf. HABERMAS, J. Direito e Democracia: ente facticidade e validade, v.I, tradução de Beno Siebeneichler, $2^{a}$ edição. Rio de Janeiro: Tempo Brasileiro, 2012, pg. 50.

${ }^{4}$ HABERMAS, J. Op. Cit., pg. 60.

${ }^{5}$ No dizer de Habermas, trata-se de um conceito semântico-dedutivo de fundamentação. Cf. HABERMAS, J. Verdade e Justificação: Ensaios Filosóficos, tradução de Milton Mota. São Paulo: Loyola, 2004, pg. 45.

${ }^{6}$ KELSEN, Hans. Teoria Pura do Direito, tradução de João Baptista Machado. São Paulo: Martins Fontes, 2006, pg. 215.
} 
normativa dentro de um ordenamento jurídico hierarquizado, só pode ser utilizado, do ponto de vista lógico, para normas infraconstitucionais, que possuem um parâmetro superior já existente que lhes condicione a construção. Essa impossibilidade se dá porque a elaboração originária da constituição, a partir do exercício do poder constituinte, não conhece, no plano fático, qualquer limitação ou condicionante prévio ${ }^{7}$.

O poder constituinte, ao fundar as bases de um novo ordenamento, o faz a partir da negação da carta constitucional anterior, e os limites, acaso existentes, seriam de ordem sociológica, moral ou ético-política, alheios, portanto, a qualquer tipo de positivação que os torne perfeitamente identificáveis e, assim, exigíveis. É por essa razão que a ciência política situa, muitas vezes, a análise do poder constituinte no estudo dos processos revolucionários, no âmbito da sociologia do direito. A constituição, vista sob a perspectiva de um poder criador ilimitado, é compreendida pela teoria constitucional como uma decisão triunfante, uma vontade que se põe coercitivamente. Interessa saber se é possível conviver com tal concepção de poder constituinte dentro de sociedades complexas que almejam o reconhecimento da correção do Direito pelos seus destinatários.

É evidente, portanto, que o estudo sobre o discurso de fundamentação das normas constitucionais deve passar, necessariamente, pela análise do exercício do poder constituinte: sua natureza, limites, consequências, titularidade, já que é pelo filtro do constituinte que se selecionam as normas que serão objeto de positivação e que passarão a ocupar um lugar normativo diferenciado dentro do sistema hierarquizado.

Conforme esclarece Colón-Ríos ${ }^{8}$, a teoria do poder constituinte pode representar uma importante ferramenta no arsenal teórico dos proponentes de uma forma democrática de constitucionalismo, uma vez que ela fornece um caminho alternativo para se pensar os sentidos e as implicações institucionais de um comprometimento com a democracia a partir das normas jurídicas fundamentais. Isso porque o exercício do poder constituinte assentado em bases inteiramente democráticas pode transformar, em termos de justiça e fundamentação, toda uma ordem jurídica através da participação popular.

Tendo em vista a relevância do poder constituinte para o Direito e, consequentemente, para toda a organização social, uma intuição fundamental pode ser

\footnotetext{
${ }^{7}$ Sobre o princípio de validade do direito positivo em Kelsen, cf. KELSEN, Hans. Teoria geral do direito e do estado, tradução de Luís Borges. São Paulo: SAFE, 2005, pg. 558 e ss.

8 COLÓN-RÍOS, Joel. I. Weak Constitutionalism: Democratic Legitimacy and the question of constituent power. New York: Routledge, 2012,pg. 7.
} 
encontrada nos mais variados textos jurídicos: não parece justificável que o exercício do poder de elaborar a constituição esteja de todo alheio a condicionamentos, em especial nos modelos políticos baseados na democracia e na proteção dos direitos humanos, que já contemplam o direito de participação, a autodeterminação normativa e as liberdades públicas e privadas como valores incorporados à cultura política - e, principalmente, como condicionantes para o exercício da democracia.

Mostra-se necessário, portanto, entender como o poder constituinte surge e se desenvolve enquanto conceito teórico do constitucionalismo e de que forma uma teoria do poder constituinte democrático possibilita que o discurso de fundamentação racional das normas constitucionais encontre o seu lugar. Nesse sentido, a pergunta inicial (como é possível fundamentar racionalmente as normas constitucionais?), transforma-se, a partir dessa linha de raciocínio, no objeto central da tese: como, no contexto de uma teoria propositiva sobre o poder constituinte democrático, pode-se demonstrar a possibilidade racional de uma fundamentação dos comandos constitucionais?

Para tentar responder a indagação, divide-se o caminho da argumento em duas partes. Na primeira, composta por dois capítulos, tem-se uma preocupação conceitual, a fim de apresentar o que a bibliografia nacional e dos países herdeiros da tradição do civil law elaborou, em termos de interpretação e sistematização, para a teoria do poder constituinte, a partir da matriz teórica comum, identificada, como consenso entre os autores, na obra de Sieyès.

Analisa-se, assim, nos dois primeiros capítulos, o conceito de poder constituinte, contextualizando-o historicamente, revisando-se a bibliografia sobre sua natureza e seus limites e definindo-se a titularidade desse poder fundacional: quem deve elaborar a constituição? Seguindo a linha da teoria constitucional desenvolvida a partir de Sieyès, tem-se uma indissociável relação entre estado de direito, na qualidade modelo estatal originário dos movimentos revolucionários liberais, a democracia, como urgência teóricoprática ${ }^{9}$ capaz de legitimar o direito positivo, e a constituição. Há uma identidade subjetiva entre o titular do poder constituinte e aqueles que serão destinatários das normas por ele produzidas, definindo-se o ordenamento jurídico como resultado de uma autodeterminação democrática baseada na carta constitucional.

\footnotetext{
${ }^{9}$ OLIVEIRA, M. A. Ética, Direito e Democracia. São Paulo: Paulus, 2010, pg. 265.
} 
O primeiro capítulo destina-se a uma breve contextualização histórica do constitucionalismo na Modernidade, bem como a uma apresentação do conceito de constituição utilizado ao longo do trabalho. Essa análise contextual parte, igualmente, de uma interpretação do livreto de Sieyès, analisado ponto por ponto, a fim de que se compreenda a ressonância que suas palavras encontraram nos teóricos do direito constitucional desde o século XIX com a definição de uma teoria mais ou menos homogênea sobre o poder constituinte.

No segundo capítulo, tem-se uma apresentação de definições sobre o poder constituinte, tal como elaboradas pelos diferentes autores que integram a tradição da teoria clássica do poder constituinte, oriunda do constitucionalismo francês. O capítulo é concluído com a sistematização dos postulados gerais dessa matriz teórica e com a discussão sobre as insuficiências dessa perspectiva para a teoria constitucional hoje.

Neste ponto, um cuidado se faz necessário. Ao constatar que a literatura jurídica nacional não vem, nos últimos anos, apresentando inovações substanciais quanto à temática do poder constituinte, buscou-se uma revisão das principais formulações sobre o poder constituinte produzidas no âmbito internacional, notadamente no que tange aos processos de mudança constitucional observados nas democracias recentes da América Latina. Esse cuidado buscou demonstrar que, mesmo à luz das contribuições publicadas nos últimos anos, uma releitura sobre o poder constituinte mostra-se relevante.

Os estudos de Colón-Ríos ${ }^{10}$, Neil Walker ${ }^{11}$, Martin Loughlin ${ }^{12}$ e Antonio Negri ${ }^{13}$ são representativos de releituras sobre a temática do poder constituinte que se mostram esclarecedoras e que, em alguma medida, permitem dialogar com os postulados da teoria clássica de matriz francesa, que será o foco da primeira parte do trabalho. Colón-Ríos preocupa-se com a influência da retórica do poder constituinte sobre o constitucionalismo na América Latina, enquanto que Neil Walker e Martin Loughlin permitem refletir sobre os conceitos contemporâneos de poder e do processo de elaboração das constituições escritas a parir de uma análise da história conceitual. Antonio Negri parte de uma análise mais

\footnotetext{
1010 COLÓN-RÍOS, Joel I. Weak Constitutionalism: Democratic Legitimacy and the question of constituent power. New York: Routledge, 2012.

${ }^{11}$ WALKeR, Neil; LOUGHLIN, Martin. The Paradox of Constitutionalism: Constituent Power and Constitutional Form. Oxford: Oxford Press, 2007.

${ }^{12}$ LOUGHLIN, Martin. Foundations of Public Law. Oxford: Oxford Press, 2012.

${ }^{13}$ NEGRI, Antonio. Insurgencies: Constituent Power and the Modern State. Minneapolis: University of Minnesota Press, 1999.
} 
pessimista sobre o poder constituinte, analisando-o à luz da matriz teórica marxista, e representa um interlocutor que permite refletir sobre as limitações fáticas ao pleno exercício do poder constituinte hoje. Todos os autores, na medida em que atualizam o debate sobre o constituinte, são utilizados para enriquecer a análise empreendida.

Na segunda parte da tese, têm-se quatro capítulos, destinados à apresentação dos pressupostos filosóficos que amparam a proposta final de uma releitura do poder constituine democrático, com foco no discurso de fundamentação das normas constitucionais.

No terceiro capítulo, discute-se a reviravolta linguístico-pragmática, que simboliza a mudança no paradigma de racionalidade responsável pelo advento das matrizes teóricas utilizadas como referencial do argumento: o procedimentalismo democrático, a teoria do agir comunicativo e a ética do discurso.

Já que o discurso de fundamentação normativa é, sobretudo, a manifestação do exercício da razão no direito, optou-se por analisar, com cuidado, a mudança da concepção kantiana de razão (uma razão monológica) para uma concepção pós-kantiana, na qual se compreende a importância da linguagem e da comunicação do processo de constituição dos sentidos do mundo. Nasce, aqui, um paradigma de razão que se define como comunicativo, discursivo, ou dialogal, e que é determinante para as teorias da democracia que se desenvolvem no século XX.

No capítulo quarto, apresenta-se a proposta habermasiana para o direito e sua relação com a democracia. A escolha por Jürgen Habermas como referencial teórico se justifica pois a sua teoria da ação comunicativa determinou o surgimento de uma correlação original entre modelo democrático, validade normativa e a legitimidade política, a qual pode ser útil para compreensão dos limites do poder constituinte.

Na linha de raciocínio filosófico habermasiana, o caminho de legitimação da ordem democrática é o procedimento de deliberação pública e generalizada, entendido como exercício, isto é, práxis, na qual o discurso - mediado pela linguagem - é o construtor dos objetos racionalmente validados, como as normas jurídicas, por exemplo. Nos ambientes democráticos cria-se, ainda que artificialmente, pelo direito, uma estrutura de participação capaz de fornecer à razão comunicativa as provas argumentativas necessárias à justificação do discurso, fundada no reconhecimento intersubjetivo. Nesse sentido, para Habermas, $a$ 
legitimidade da regra se mede pela resgatabilidade discursiva de sua pretensão de validade normativa. A associação com a democracia se faz na medida em que o que conta, em última instância, é o fato de elas [as normas] terem surgido num processo legislativo racional $^{14}$.

Se, para Habermas, a realidade com a qual confrontamos nossas proposições não é uma realidade “nua”, mas já, ela própria, impregnada pela linguagem ${ }^{15}$, é justificável que, no capítulo III, se faça uma correlação entre a proposta de releitura da teoria clássica do poder constituinte e a reviravolta linguístico-pragmática, já que toda experiência humana é linguisticamente estruturada. É através da linguagem que se formam os juízos e as proposições sobre o mundo, que permitem a comunicação e a própria construção do conhecimento.

O autor alemão propõe, assim, uma tese sobre a legitimação da legalidade pelo procedimento democrático, capaz de oferecer uma força integradora à sociedade moderna após a desconstrução da eticidade das sociedades tradicionais. Sua teoria, exposta no capítulo V, mostra-se, portanto, adequada a uma proposta de fundamentação da ordem constitucional baseada no exercício do poder constituinte democrático, na medida em que, como esclarece Villas-Boas, na teoria habermasiana, tem-se um nexo conceitual intrínseco entre Estado de direito e democracia ${ }^{16}$.

Busca-se, no quarto capítulo, associar os conceitos de esfera pública, sociedade civil, princípio do discurso e princípio democrático, desenvolvidos por Habermas, à compreensão do exercício do poder constituinte enquanto poder comunicativo, a fim de se propor uma teoria democrática e discursiva sobre o processo de elaboração das cartas constitucionais.

É importante que se compreenda, portanto, que não se trata de uma tese sobre Habermas e sua leitura sobre o direito. O objeto central - o poder constituinte e sua relação com o discurso de fundamentação da norma constitucional - é tematizado a partir da contribuição habermasiana, mas não se restringe a ela e tampouco pretende esgotar as suas possibilidades de interpretação. A teoria habermasiana detém uma complexidade própria

\footnotetext{
${ }^{14}$ HABERMAS, J. Op. Cit., pg. 50.

${ }^{15}$ HABERMAS, J. Verdade e Justificação: Ensaios Filosóficos, tradução de Milton Mota. São Paulo: Loyola, 2004, pg. 45.

${ }^{16}$ VILLAS-BOAS, O. Legalidade e Legitimidade no pensamento de Jürgen Habermas, in: NOBRE, Marcos; TERRA, Ricardo (orgs.). Direito e Democracia: Um guia de leitura de Habermas. São Paulo: Malheiros, 2008, pg. 157.
} 
cuja análise renderia teses próprias, nas quais se poderia discutir, de forma pormenorizada, cada detalhe de sua linha argumentativa. A sua contribuição é utilizada como referencial teórico para se analisar as insuficiências da teoria clássica sobre o poder constituinte e propor uma releitura, mais atual, sobre o processo de nomogênese constitucional a partir do procedimentalismo.

Por essa razão, optou-se por selecionar, entre os textos do filósofo, aqueles que são mais representativos de sua análise sobre a relação entre direito e democracia, e de sua proposta para o procedimentalismo no contexto da ética do discurso. Interpretações sobre a obra de Habermas, e, com maior detalhe, aquela enfrentada por Neves em seu Entre Têmis e Leviatã: uma relação difícil ${ }^{17}$, são utilizadas para esclarecer alguns pontos problemáticos e obscuros do argumento habermasiano.

O capítulo sexto e final da tese, assim, contempla a releitura da teoria do poder constituinte enquanto poder democrático, capaz de favorecer a institucionalização de uma ordem jurídica legítima. No capítulo final, optou-se por reduzir as citações diretas no texto, a fim de que o argumento pudesse fluir livremente, levando-se em conta que as referências teóricas que amparam as propostas finais já são expostas nos capítulos anteriores.

Os estudos sobre o poder constituinte mostram-se escassos na literatura jurídica brasileira, especialmente no que diz respeito ao enfoque sobre as suas limitações e modo de exercício. Considerado potência de fato, as teorizações sobre essa modalidade de poder limitam-se, muitas vezes, a estabelecer a classificação tradicional, que o subdivide entre poder constituinte originário e derivado, e a identificar no povo o titular legítimo para exercer a prerrogativa de elaborar a constituição.

O tema se mostra, apesar da escassez de escritos nacionais, da maior relevância, tendo em vista o histórico de instabilidade constitucional a que estão submetidas as sociedades em desenvolvimento: nos últimos sessenta anos, foram elaboradas três constituições no Brasil (1946, 1967 e 1988), cujas características e níveis de eficácia mostram-se conflitantes e divergentes entre si, revelando um período de intensa conflituosidade institucional e política na história recente do país.

\footnotetext{
${ }^{17}$ NEVES, Marcelo. Entre Têmis e Leviatã: uma relação difícil. São Paulo: Martins Fontes, 2007.
} 
As descontinuidades da experiência constitucional de um povo mencionadas por Saldanha ${ }^{18}$ justificam que um temor com o processo de mudança da constituição subsista mesmo quando a carta em vigência goza, pelo menos no plano da retórica jurídica, de um alto nível de legitimidade, como é o caso brasileiro. A subversão da ordem constitucional pelo exercício do poder constituinte não pode ser encarada como processo que sempre irá enriquecer a conquista da liberdade individual e das garantias sociais. A experiência histórica, mesmo no caso brasileiro, indica retrocessos e descompassos entre os anseios sociais e as decisões tomadas nos espaços políticos formais. É por essa razão que uma teoria da mudança constitucional constitui uma urgência não só acadêmica, mas prática.

Para Nolte e Schilling-Vacaflor, as mudanças constitucionais observadas na América Latina nas últimas décadas têm despertado um interesse justificável nas mais diversas áreas do conhecimento. É preciso entender o processo de elaboração das constituições e de sua permanência ou mutabilidade. Para os autores, a história constitucional do século XX é uma história de mudança, já que, das quase 200 constituições existentes no mundo hoje, mais da metade foi escrita ou reescrita no último quarto do século ${ }^{19}$. Aí está, portanto, o poder constituinte se manifestando como uma ocorrência histórica mais frequente e problemática do que seu conceito pode sugerir.

Ao defini-lo como uma potência irrestrita, incondicionada e originária, a teoria clássica não é capaz de assegurar qualquer nível de legitimidade para o resultado de seu exercício, no caso, a nova constituição. Ao ser positivada, a carta constitucional se impõe como fato normativo, mas necessita de um fundamento de validade decorrente do reconhecimento dos atores sociais, sob pena de ineficácia. A preocupação principal é, portanto, propor uma compreensão de poder constituinte capaz de oferecer uma alternativa racional às compreensões tradicionais, associando-o à organização democrática do poder e à institucionalização dos procedimentos discursivos como fatores de legitimidade.

\footnotetext{
${ }^{18}$ SALDANHA, Nelson. Ibidem, pg. 12.

19 NOLTE, Detlef; SCHILLING-VACAFLOR, Almut. New Constitutionalism in Latin America: Promises and Practices. Surrey: Ashgate, 2012.
} 
 \\ CONSTITUCIONALISMO NA MODERNIDADE}

Definir poder constituinte e classificá-lo no sistema da teoria constitucional tradicional pressupõe a compreensão do contexto histórico de surgimento do conceito e a precisa delimitação do sentido de constituição que se utilizará no percurso argumentativo deste trabalho, pois se tratam de expressões impregnadas de um sentido histórico forjado pelo advento da Modernidade.

$\mathrm{Na}$ medida em que o poder constituinte apresenta-se como construção do Liberalismo Clássico francês e seu exercício é condicionado pela existência de uma constituição escrita e rígida, inicia-se o estudo pela apresentação do quadro conceitual e do referencial teórico sobre o poder constituinte, iniciado no século XVIII e aprimorado ao longo dos séculos seguintes.

O rigor metodológico com a delimitação conceitual mostra-se necessário, uma vez que se busca compreender o sentido estrutural que os conceitos assumem e a maneira pela qual eles funcionam no quadro global em que se exprimem ${ }^{20}$. Busca-se, assim, uma abordagem analítica, que possibilite uma compreensão contextual das ideias políticas. Isso porque:

Os conflitos políticos e sociais do passado devem ser descobertos e interpretados através do horizonte conceitual que lhes é coetâneo e em termos dos usos linguísticos, mutuamente compartilhados e desempenhados pelos atores que participaram desses conflitos. Desse modo, o trabalho de explicação conceitual quer tornar as proposições passadas mais precisas em seus termos próprios ${ }^{21}$.

Para a história dos conceitos, expressões como sociedade civil, Estado, poder atravessam os tempos com profundas transformações em seu sentido, motivadas pelas

\footnotetext{
${ }^{20}$ DUSO, Giuseppe (org.). O Poder: História da Filosofia Política Moderna, tradução de Andrea Ciacchi, Lísia da Cruz e Giuseppe Tosi. Petrópolis: Vozes, 2005, pg. 11.

21 JASMIN, M. G.; FERES JÚNIOR, J. História dos conceitos: dois momentos de um encontro intelectual. Rio de Janeiro: Edições Loyola e Editora PUC-Rio, 2006, pg. 23.
} 
mudanças na estrutura social e na filosofia política dominante. Buscando uma associação entre história e linguagem, a historiografia conceitual propõe uma hermenêutica própria dos textos políticos, na tentativa de estabelecer as transformações de sentido dos conceitos no tempo, distinguindo o que permanece daquilo que é mutável pelos usos da linguagem. No léxico político é preciso diferenciar o que permanece atrelado à palavra, ao termo, e aquilo que é objeto da transformação semântica motivada pela transformação cultural. Nessa perspectiva, o conceito de constituição depende diretamente de sua temporalidade e de quem são os sujeitos que se apropriam do termo e do contexto de sua utilização discursiva.

Há uma indiscutível plasticidade nos sentidos utilizados pelos diferentes intérpretes, nas distintas épocas, o que torna necessário estabelecer, de princípio, o sentido de constituição e de poder constituinte de que o trabalho se apropria para que o texto se desenvolva com a clareza necessária. Nesse sentido, compreende-se o conceito como uma construção cultural - portanto, histórica e geograficamente situada. O sentido que se atribui ao termo constituição e à expressão poder constituinte é definido em função dos acontecimentos decorrentes da consolidação do Estado Burguês e do ideário que fundamentou as transformações sociais, políticas e econômicas vividas pelas sociedades ocidentais na Idade Moderna.

Somente com esse cuidado terminológico pode-se compreender o artigo XVI da Declaração dos Direitos do Homem e do Cidadão, segundo a qual a sociedade que não garanta a separação de poderes e as liberdades individuais não possui uma constituição. Só faz sentido um dispositivo com esse teor se se compreender a constituição como um conjunto material de normas que positivam determinados valores políticos historicamente situados. Do mesmo modo, só se pode falar em poder constituinte no sentido moderno a partir das teorias contratualistas liberais, que propõem a associação da soberania popular à representação como modelo de organização social mais avançado, sendo o povo o titular da força que institui a nova ordem política, simbolizada pela carta constitucional, através do exercício do poder constituinte.

Assim, sustenta-se a ideia de que a unidade da palavra não deve ser tomada como uma unidade de conceito ${ }^{22}$, um rótulo comum $^{23} \mathrm{e}$, portanto, a utilização do termo ao longo

\footnotetext{
${ }^{22}$ DUSO, Giuseppe. Ibidem, pg. 15.

${ }^{23}$ NEVES, Marcelo. Transconstitucionalismo. São Paulo: Martins Fontes, 2009, pg. 20
} 
do trabalho científico deve ser fundamentada na correta precisão do conceito a ele atribuído, evitando-se o esgotamento semântico dos conceitos políticos tal como alertado por Neves. Para o autor, o uso inflacionário do termo constituição tornou-o muito vago, perdendo o seu significado histórico, normativo e funcional ${ }^{24}$. Salienta que não apenas pela questão semântica da vagueza e ambiguidade, mas sobretudo pela dimensão pragmática do seu emprego, "constituição” tem sido uma expressão prestes a usos arbitrariamente metafóricos ${ }^{25}$, o que deve ser afastado pela teoria constitucional.

A fim de evitar tal imprecisão e buscando estabelecer, desde o princípio, o referencial teórico de que se utiliza este trabalho, apresenta-se, no primeiro tópico, o sentido de constituição e de poder constituinte que se empregará, a partir da contextualização histórica dos conceitos.

\subsection{A Constituição da Modernidade}

A teoria constitucional da Modernidade é desenvolvida a partir da conceituação de constituição como carta política fundamental. A organização do poder decorrente estruturação do Estado pelo Direito é feita por meio do aparato normativo instituído pela constituição, produto do exercício do poder pelo soberano. A constituição materializa simbolicamente o conjunto de valores que integram a própria noção de estado de direito forjada pela ideologia revolucionária da burguesia.

Para que se compreenda o sentido de constituição construído pelo movimento constitucionalista europeu é preciso, assim, afastar-se de uma definição meramente descritiva. De acordo como uma perspectiva sociológica, toda e qualquer organização social estruturada politicamente tem suas normas definidas no que se chama constituição, ainda que não exista expressão escrita de tal arcabouço normativo. Bonavides denomina este o conceito material de constituição, assim definindo-o:

Tudo quando for, enfim, conteúdo básico referente à composição e ao funcionamento da ordem política exprime o aspecto material da Constituição.

\footnotetext{
${ }^{24}$ NEVES, Marcelo. Ibidem, pg. 5.

${ }^{25}$ NEVES, Marcelo. Op. cit.
} 
Debaixo desse aspecto, não há Estado sem Constituição, Estado que não seja constitucional, visto que toda sociedade politicamente organizada contém uma estrutura mínima, por rudimentar que seja ${ }^{26}$.

Para Neves, é este o conceito histórico-universal de constituição, que se apresenta no plano empírico, para apontar que em toda sociedade ou Estado há relações estruturais básicas de poder, determinantes também das formas jurídicas ${ }^{27}$. Esse não é, entretanto, o sentido de constituição da Modernidade. Para Neves, o direito nascido do Liberalismo e de suas Cartas de Direitos é a consequência da dessacralização do poder, e as constituições são, nesse sentido, pactos com pretensão universalizante, os quais, estruturando a organização jurídico-política, limitam o poder do Estado ao positivar os direitos fundamentais ${ }^{28}$. Goyard-Fabre corrobora da ideia, ao afirmar que $o$ reconhecimento de uma ordem sociopolítica independente da ordem eclesiástica abria, assim, o caminho para a concepção do Estado moderno, cuja soberania será apresentada como "a forma” ou a "essência" 29.

Surge, portanto, uma constituição própria do constitucionalismo europeu moderno, que decorre da separação entre Direito e Política e da intensificação da complexidade social experimentada pela Modernidade, o que motivou a despersonalização e a institucionalização do poder ${ }^{30}$. Goyard-Fabre assinala que:

No Estado, a ideia de Constituição foi assim pensada como o analogon moderno do que haviam sido outrora a Magna Carta de João sem Terra no reino da Inglaterra e as "leis fundamentais" da monarquia francesa. Portanto, ela mostrou-se palavra originária das competências normativas do Estado, que fixa para o princípio do direito público o âmbito no qual deve exercer-se e assume ipso facto um valor programático. Nessa maneira nova de compreender a Constituição, conjugaram-se duas ideias mestras e complementares, que a doutrina, desde então, firmou e aprimorou constantemente. Por um lado, a Constituição define o estatuto orgânico do Estado e é nela que reside a base da potência estatal. Por outro lado, o aparelho jurídico do Poder se delineia segundo o esquema da "hierarquia das normas".

A constituição em sentido moderno é, portanto, a constituição rígida, escrita, que positiva as liberdades públicas, limita as competências do Estado, estabelece o procedimento representativo como estrutura básica de organização do poder político, subdividindo-o em funções legislativa, executiva e judicante. Nesse sentido, tem-se que a

\footnotetext{
${ }^{26}$ BONAVIDES, Paulo. Curso de Direito Constitucional, 14a edição. São Paulo: Malheiros, 2004, pg. 81.

${ }^{27}$ NEVES, Marcelo. Ibidem, pg. 54.

${ }^{28}$ NEVES, Marcelo. Ibidem, pg. 20.

${ }^{29}$ GOYARD-FABRE, Simone. Princípios Filosóficos do Direito Político Moderno, tradução de Irene Paternot. São Paulo: Martins Fontes, 2002, pg. 9.

${ }^{30}$ BONAVIDES, Paulo. Ibidem, pg. 144.

${ }^{31}$ GOYARD-FABRE, Simone. Ibidem, pg. 103.
} 
premissa capital do Estado Moderno é a conversão do Estado absoluto em Estado constitucional; o poder já não é de pessoas, mas de leis ${ }^{32}$, conforme salienta Bonavides.

Saldanha esclarece que o sentido histórico do constitucionalismo desemboca na ideia da "necessidade" de serem constituídos/constitucionalizados os estados, sob a crença de que com isto se conjurarão males ${ }^{33}$ relacionados à difícil tensão entre legalidade e legitimidade. A constituição do constitucionalismo simboliza um produto dessa "necessidade", uma consequência do movimento histórico visto, sob a perspectiva da época, como uma oportunidade única de promover uma completa reorganização de poder.

A contribuição do autor sobre o sentido de constituição pode ser esclarecedora. Entendida como uma relação histórica, ela é vista por Saldanha como o meio de estabelecer a conexão mútua entre o fato e a ideia na vida política de uma sociedade, combinando essência e existência política do Estado, na medida em que exprime verbalmente um sistema de intenções. O significado simbólico da constituição moderna não escapa ao constitucionalista, que reconhece na constituição a base moderna do direito e do Estado, um tipo inédito de promessa, de compromisso político, de um povo para consigo mesmo ${ }^{34}$.

Ao revelar a orientação geral das estruturas jurídicas, o conceito de constituição inicia e abrange a problemática do direito positivo. Desse modo, tem-se, na carta constituição, uma manifestação da complementaridade existente entre direito e estado, de modo que:

Esse conceito representa o vínculo moderno entre os conceitos de Estado e de Direito; A Constituição exprime o propósito estatal do direito e o propósito jurídico do Estado. Ou ainda: A Constituição fornece ao Estado a sua justificação jurídica e ao direito o seu poder básico ${ }^{35}$.

Por abrager o direito positivo e organizar o próprio exercício do poder, assume a constituição uma posição hierárquica diferenciada dentro do sistema jurídico, o que foi evidenciado por Kelsen já no século XX.

Neste ponto, é necessário um esclarecimento justificado pelo intervalo histórico entre as primeiras elaborações do constitucionalismo clássico e o normativismo constitucionalista do século XX. Enquanto que para um burguês oitocentista a constituição

\footnotetext{
${ }^{32}$ BONAVIDES, Paulo. Teoria do Estado, $4^{\text {a }}$ edição. São Paulo: Malheiros, 2003, pg. 29.

${ }^{33}$ SALDANHA, Nelson. O Poder Constituinte. São Paulo: Revista dos Tribunais, 1986, pg. 11.

${ }^{34}$ SALDANHA, Nelson. Ibidem, pg. 68.

${ }^{35}$ SALDANHA, Nelson. Ibidem, pg. 56.
} 
deve deter um rol de matérias essenciais: separação de poderes, liberdades públicas, representatividade popular, em Kelsen, a constituição, enquanto tal, não goza de matérias especificamente constitucionais, bastando-lhe o status normativo diferenciado. O conceito de constituição é, para Kelsen, estritamente formal.

O caráter diferenciado da constituição dentro do Direito é, apesar disso, uma constante: tanto para o constitucionalismo revolucionário como para o normativismo do século XX a constituição exerce a função de servir de fundamento formal para todo o Estado, organizando os poderes constituídos e determinando, por consequência lógica, a elaboração de todas as demais normas jurídicas e a tomada de decisões políticas.

Goyard-Fabre salienta que é tamanha a importância da constituição para o modelo de estado forjado da modernidade que todo o pensamento político do século XIX é profundamente influenciado pelo conceito de constituição, tornando-se, em verdade, um pensamento constitucional ${ }^{36}$. Isto significa compreender ser o nascimento do Estado identificado com o próprio nascimento da constituição, que lhe assume o status de norma fundamental.

Bobbio, em seu Dicionário de Política, apresenta tal relação necessária entre o conceito de constituição e o Estado moderno nos seguintes termos:

\begin{abstract}
As primeiras constituições se inseriram no quadro de um processo de limitação e fragmentação do poder absoluto, tal como o que se consolidou nas monarquias europeias. Por isso ainda hoje o próprio conceito de constituição é frequentemente considerado como coincidente com o de poder político repartido entre diversos órgãos constitucionais, sendo reconhecidas aos cidadãos, além de uma série de direitos fundamentais, adequadas garantias contra os abusos cometidos pelos titulares dos órgãos do poder político. ${ }^{37}$
\end{abstract}

O conceito de constituição que se trabalhará neste estudo é, portanto, o conceito de constituição material exposto, que identifica a carta constitucional com um conjunto de normas voltadas à estruturação do estado de direito, a partir da limitação do poder e da organização dos procedimentos de produção e execução das normas estatais. O conceito é simultaneamente político - no sentido de que a constituição coincide com a fundação do próprio Estado - e jurídico, tendo em vista a natureza normativa da carta constitucional.

\footnotetext{
${ }^{36}$ GOYARD-FABRE, Simone. Ibidem, pg. 105.

${ }^{37}$ BOBBIO, Norberto; MATTEUCCI, Nicola; PASQUINO, Gianfranco. Dicionário de Política, $12^{\mathrm{a}}$ Edição. Brasília: Editora UnB, 2004, pg. 258.
} 
O estado moderno pode ser qualificado, assim, como um estado de direito, na medida em que a diferenciação entre poder e direito favoreceu a criação de mecanismo de contenção do uso da força, ou, no dizer de Neves, a vinculação jurídica do poder, o que possibilita o seu limite e controle pelo direito ${ }^{38}$.

A constituição é, portanto, o ponto comum ao Estado de Direito, seja ele de orientação liberal, social, democrática, etc. Enquanto ordem política limitada pelas normas jurídicas, o Estado de Direito necessita de constituição como norma básica, originária, criada a partir de um procedimento derivado do exercício do poder de fato e capaz de subordinar toda a elaboração normativa posterior.

\subsection{Do Conceito de Poder Constituinte e sua Contextualização Histórica}

Sendo a constituição o conjunto de disposições escritas que fundam o estado de direito liberal, é certo afirmar que seu surgimento decorre do exercício de uma potência fundacional chamada pela teoria constitucionalista de poder constituinte, uma ideia cuja gênese é repleta de ambiguidades.

O poder constituinte surge na teoria constitucional moderna associado às discussões sobre a legitimidade no exercício do poder político e à afirmação da soberania nacional - e, posteriormente, popular. Não apenas as limitações jurídicas ao exercício do poder, mas as discussões sobre a sua titularidade passaram a ocupar a pauta da Ilustração, no sentido de fundamentar filosoficamente as transformações políticas em ebulição no continente europeu.

A gênese da ideia constituinte só se faz possível após uma transformação determinante no conceito de soberania concebido no advento da Modernidade: a subdivisão da função normativa em duas tarefas distintas, uma referente à atividade de elaborar a constituição, outra destinada à produção da legislação ordinária ${ }^{39}$. Para Pimentel,

\footnotetext{
${ }^{38}$ NEVES, Marcelo. Ibidem, pg. 21.

39 Cf. LENOWITZ, Jeffrey. Why ratification: Constituent power and the unexamined procedure. In: CAYLA, Olivier; PASQUINO, Pasquale. Le pouvoir constituant et l'Europe (direc.). Paris: Dalloz, 2001, pg. 15. Note that two critical presuppositions underlie this concept: the distinction between ordinary law and extraordinary law, and the absence of any other source of political authority other than the people themselves.
} 
essa subdivisão não faria sentido para um burguês setecentista, na medida em que a soberania, entendida como poder absoluto, se manifestava como força indivisível, única. Assim, até 1787, a teoria da soberania se opõe ao nascimento de um poder constituinte, na medida em que ela supõe um poder legislativo único e indivisível ${ }^{40}$.

A subdivisão que viabilizou o surgimento de uma teoria do poder constituinte foi empreendida por intermédio das teorias contratualistas, quando se começa a gestar a ideia de constituição enquanto fruto de um acordo: um ato de vontade livre. É pela transformação da noção de contrato social que a função constituinte começa a se impor. A constituição é o ato que simboliza esse ato de vontade primário, a partir do qual toda a legislação ordinária pode ser produzida. Há, no bojo das doutrinas contratualistas, inegavelmente, uma distinção de grau de importância entre as chamadas leis fundamentais e o restante da legislação ordinária. Pimentel, em análise da gênese histórica da ideia constituinte na França, pontua:

Para adquirir uma verdadeira consistência jurídica, tudo se passou como se a noção de constituição tivesse que passar pela figura contratual e seguir o mesmo itinerário do contrato social, transformando-se um pacto de governo em um pacto de associação. [...] É nesse sentido que, na doutrina francesa, se operou uma releitura do tema da lei fundamental. Não se tratava mas de uma norma consuetudinária, repleta de privilégios, intangível e anônima, que pretendia proteger os parlamentos: as leis fundamentais, uma vez transformadas em contrato, tornaram-se revisáveis, antes de estarem pura e simplesmente sujeitas à vontade soberana do povo ${ }^{41}$.

Como pontua Colón-Ríos pontua, ao encontro dessa ideia, só é possível identificar uma teorização sobre o poder constituinte na segunda metade do século XVIII, no contexto das revoluções americana e francesa. Apesar disso, já se percebe, nas teorias contratualistas forjadas no século XVII, o desenvolvimento de suas ideias principais. Autores como John Locke e Jean-Jacques Rousseau, embora não tematizem expressamente o questionamento sobre o poder constituinte, estabelecem, com suas contribuições, a justificação teórica para o direito de resistir a um regime opressivo, que é o cerne da teoria do poder constituinte apresentada por Sieyès ${ }^{42}$.

\footnotetext{
${ }^{40}$ PIMENTEL, Carlos-Miguel. Du contrat social à la norme suprême: l'invention du pouvoir constituant. In: Jus Politicum: Autour de la notion de Constitution, n. 3, 2009, pg. 2. Disponível em: http://www.juspoliticum.com/Du-contrat-social-a-la-norme.html. Último acesso em 9/1/13. [tradução livre] ${ }_{41}$ PIMENTEL, Carlos-Miguel. Ibidem, pg. 12.

${ }^{42}$ COLÓN-RIOS, Joel I. Weak Constitucionalism: Democratic Legitimacy and the question of constituent power. New York: Routledge, 2012, pg. 7.
} 
Esse "direito de resistência" tem reflexos importantes no postulado da revisibilidade das normas fundamentais. $\mathrm{Na}$ medida em que não são mais representativas de um estado imutável de coisas, elas estão sujeitas à reavaliação pelo soberano, que não fica condicionado à sua observância, pois pode resistir à opressão de um regime ilegítimo. Esse caráter de revisibilidade é o que explica a caracterização do poder constituinte como um poder ilimitado e incondicionado, autônomo, porque é um poder que nasce como um ato de subversão da ordem estabelecida.

Busca-se demonstrar, no próximo subtópico, como as teorias contratualistas influenciaram o desenvolvimento da teoria do poder constituinte na Modernidade.

\subsubsection{O Contratualismo Europeu e as Primeiras Teorizações sobre a} Legitimação do Poder Democrático

As teorias contratualistas concebidas a partir da Ilustração, ainda que fundamentalmente distintas entre si em suas proposições, foram especialmente importantes para o discurso de legitimação do poder pós-revolucionário, pois ofereciam alternativas capazes de justificar a ascensão da classe burguesa ao poder a partir da noção de contrato. Bobbio et ali identificam a origem do contratualismo no começo do século XVII, passando ao século XVIII. Tem-se como principais expoentes da escola os nomes de Althusius, Hobbes, Spinoza, Pufendorf, Locke, Rousseau e Kant, nas obras dos quais é possível vislumbrar o comum uso de uma mesma sintaxe ou de uma mesma estrutura conceitual para racionalizar a força e alicerçar o poder no consenso ${ }^{43}$.

Nas teorias contratualistas, busca-se uma forma de justificação do poder fundada na ideia de consenso - no sentido que o estado surge e adquire sua força de ação a partir da vontade dos próprios indivíduos reunidos em sociedade. O estado, assim, é colocado a serviço da liberdade individual, uma condição que preserva e garante o espaço de ação dos sujeitos.

Para Duso, o contratualismo é caracterizado como uma nova forma de saber, fundada numa compreensão de racionalidade capaz de superar as diversas opiniões sobre a

\footnotetext{
${ }^{43}$ BOBBIO et ali. Ibidem., pg. 272.
} 
justiça. A tarefa é, portanto, deduzir uma forma política que garanta a paz e a ordem na vida social e que possa contar com a adesão racional dos sujeitos. Nesse sentido:

O contrato social se torna assim algo mais radicalmente novo. [...] Já neste cenário novo, o contrato constitui uma novidade absoluta: antes só tínhamos indivíduos, depois um ser coletivo, um corpo política, uma única pessoa, que todos quiseram, através do contrato, e à qual, portanto, todos devem estar submetidos. Agora não se assiste à transferência de um poder preexistente, que está nas coisas, mas à criação do poder civil; e não há diversos poderes num quadro de diversidades hierarquicamente ordenadas, mas uma summa potestas que é, ao mesmo tempo, a única potestas $^{44}$.

Percebe-se claramente, como já exposto anteriormente, como na Modernidade se caminha para uma dessacralização do poder, no sentido de desvincular o poder do Estado de fundamentos estritamente religiosos. É nesse sentido que Duso afirma tratar-se da criação do poder civil e não de uma simples transferência. A potência criadora do estado é, portanto, a vontade dos indivíduos reunidos, o consentimento, uma construção social.

Para a concepção contratualista de poder, o estado é a instituição social que marca a transformação do Estado de natureza - no qual os homens são regidos por normas suprapositivas, o direito natural - para o estado de sociedade, onde a normatividade é produzida artificialmente pelo homem organizado no corpo político. A ideia da artificialidade da produção normativa é importante, na medida em que só se reconhece como legítima as normas que são produzidas no sentido de preservar o estado de liberdade.

Esclarece Duso estar o conceito de soberania fundado sobre os direitos dos indivíduos e vinculados à sua realização, uma vez que o poder não é entendido como força preexistente, mas como uma força legítima. Nesse sentido, a partir do raciocínio do autor, o primeiro aspecto da legitimação consiste no reconhecimento da vontade de todos os indivíduos como base do poder ${ }^{45}$.

A construção do ideário republicano, que envolve o reconhecimento de um sujeito de direitos situado no centro da ordem política, dotado de poder de decisão e cuja proteção é o objetivo maior do Estado, está diretamente relacionada à elaboração das primeiras cartas constitucionais nos moldes republicanos. Tem-se, com o contratualismo, uma estreita dependência entre estado, princípio representativo, democracia e liberdades individuais.

${ }^{44}$ DUSO, Giuseppe (org.). O Poder: História da Filosofia Política Moderna. Petrópolis: Vozes, 2005, pg. 115.

${ }^{45}$ DUSO, Giuseppe (org.). Ibidem., pg. 116. 
John Locke, expoente da vertente inglesa da escola contratualista, justifica o nascimento do estado como mecanismo de proteção do principal direito natural - a propriedade $^{46}$. Para o autor, o estado de natureza é caracterizado como um estado de liberdade, no qual os sujeitos podem regular suas ações e dispor de suas posses e pessoas do modo como julgarem acertado, sem pedir licença ou depender da vontade de qualquer outro homem $^{47}$. Segundo Locke, todo homem é considerado executor da lei da natureza e o excesso no cumprimento do poder de punição é que leva os indivíduos ao estado de guerra: a ausência de um juiz comum dotado de autoridade coloca todos os homens em estado de natureza; a força sem direito sobre a pessoa de um homem causa o estado de guerra, havendo ou não um juiz comum $^{48}$.

Segundo a proposta de Locke, os homens deixam o estado de natureza originariamente bom - e passam ao estado de sociedade como meio de evitar o estado de guerra, sendo característico do estado de sociedade a existência de uma autoridade, um poder sobre a Terra, do qual se possa obter amparo por meio de apelo ${ }^{49}$, o Estado, portanto. É preciso chamar atenção, todavia, que a simples instituição do poder não garante, para Locke, por si só, o estado de liberdade.

Isso se dá porque somente o consentimento - daí a noção de contrato - pode ser o fundamento legítimo do exercício do poder de elaboração das leis. Nesse sentido, conforme afirma Locke, a liberdade do homem em sociedade consiste em não estar submetido a nenhum outro poder legislativo senão àquele estabelecido no corpo político mediante consentimento ${ }^{50}$. Tem-se, portanto, uma teoria sobre o fundamento do poder político em bases profundamente democráticas, utilizando-se como critério de decisão o princípio majoritário: é necessário, no dizer de Locke, que esse corpo se mova na direção determinada pela força predominante, que é o consentimento da maioria ${ }^{51}$.

A lei positiva criada pelo Estado e por ela aplicada é o resultado de um consentimento dos próprios sujeitos, que se autolegislam como forma de evitar o estado de guerra, prejudicial à paz e manutenção da propriedade, indispensável ao desenvolvimento da vida individual. Pode-se afirmar que o filósofo inglês busca assegurar a individualidade

\footnotetext{
${ }^{46}$ LOCKE, John. Dois Tratados sobre o Governo, tradução de Julio Fischer. São Paulo: Martins Fontes, 2005 , pg. 456.

${ }^{47}$ LOCKE, John. Ibidem, pg. 382.

${ }^{48}$ LOCKE, John. Ibidem, pg. 398.

${ }^{49}$ LOCKE, John. Ibidem, pg. 400.

${ }^{50}$ LOCKE, John. Ibidem, pg. 402.

${ }^{51}$ LOCKE, John. Ibidem, pg. 469.
} 
reclamada pelo liberalismo a partir da instituição do Estado, que passa a incorporar a função de garantir a liberdade de cada qual segundo a lei da liberdade natural.

O estado é compreendido como uma criação artificial dos homens e voltado ao atendimento de determinados fins, estritamente relacionamentos à preservação da propriedade privada e do espaço de autonomia individual. A participação dos sujeitos através da vontade é o que legitima e garante o exercício controlado e contido do poder político.

Em Rousseau, tem-se o desenvolvimento da teoria do contrato social em termos mais republicanos, com a criação do conceito de vontade geral. Nascido em 1712, o filósofo publica a obra $O$ Contrato Social no ano de $1762 \mathrm{em}$ plena Ilustração francesa. $\mathrm{O}$ estudo filosófico-político de Rousseau é desenvolvido a partir de uma indagação: pode existir, na ordem civil, alguma regra de administração legítima e segura, considerando os homens tais como são e as leis tais como podem ser $^{52}$ ?

Silvestrini, em estudo minucioso sobre a gênese das ideias de Rousseau, entende que a sua filosofia tem duas partes principais, uma relativa à definição dos princípios universais do direito natural e do direito positivo, outra concernente à moralidade individual, tematizada em obras como Émile ${ }^{53}$. Essa distinção é importante, na medida em que, em Rousseau, o conceito de racionalidade está amparado na noção de vontade, o que lhe permitiu criar uma noção de autonomia moral indispensável ao seu modelo político. Se o contrato social depende do consenso racional, somente indivíduos moralmente autônomos são capazes de participar politicamente, orientando sua vontade para o bem comum. Desse modo, tem-se, em Rousseau, uma proposta de direito natural como um desenvolvimento de uma ciência moral amparada na noção de virtude ${ }^{54}$.

Para a intérprete, Rousseau é um filósofo que ocupa um lugar na história da filosofia bastante peculiar, marcado por paradoxos, contrariedades e antagonismos. Isso porque as interpretações de sua obra conduzem tanto ao liberalismo como ao totalitarismo, o francês é identificado ora como maior inspirador da revolução e ora como idealizador da restauração monárquica. Para Silvestrini, a importância de Rousseau está na sua proposta

\footnotetext{
${ }^{52}$ ROUSSEAU, Jean-Jacques. O Contrato Social, tradução de Antonio Danesi. São Paulo: Martins Fontes, 2001, pg. 7.

${ }^{53}$ SILVESTRINI, Gabriella. Religion naturelle, droit naturel et tolerance dans la "profession de foi du vicaire Savoyard”. In: Archives de philosophie, Centre de Sèvres, 2009, tome 72, pg. 47

${ }^{54}$ SILVESTRINI, Gabriella. Le republicanism de Rousseau mis em contexte: le cas de Genève. In: Les études philosophiques, 2007, n. 83, pg. 521.
} 
de uma forma de democracia constitucional identificada na figura da república, a qual pode conviver com uma pluralidade de formas políticas ${ }^{55}$.

Rousseau é identificado como um dos idealizadores do procedimentalismo democrático. Segundo Habermas, tem-se tanto na filosofia de Rousseau como nas propostas de Kant, o modelo de um contrato social que permite aos parceiros do direito regular democraticamente a sua convivência, tornando imperativa uma exigência metódica de um fundamentação procedimental do direito. O questionamento fundamental sobre a legitimidade do exercício do poder conduziu Rousseau a deduzir condições procedimentais para uma formação racional da vontade, nos termos expostos pelo procedimentalismo contemporâneo ${ }^{56}$.

A preocupação primordial de Rousseau é, portanto, a conquista da liberdade, que é assegurada através da instituição de um governo legítimo. Rousseau reconhece que a organização social da época não assegura a liberdade e propõe uma mudança do direito em face de um novo fundamento de legitimação ${ }^{57}$ : a vontade, simbolizada pela figura do contrato, o pacto social. De acordo com o autor, só se é obrigado a obedecer aos poderes legítimos, sendo as convenções a base de toda a autoridade legítima entre os homens ${ }^{58}$. Buscando superar a situação de escravidão e garantir a conquista da liberdade, é necessário promover a união e a integração social, uma vez que:

Ora, como os homens não podem engendrar novas forças, mas apenas unir e dirigir as existentes, não têm meio de conservar-se senão formando, por agregação, um conjunto de forças que possa sobrepujar a resistência, aplicando-as a um só móvel e fazendo-as agir em comum acordo. ${ }^{59}$

É inovadora a proposta de Rousseau pois supera a perspectiva puramente individualista do liberalismo clássico, propondo a união das vontades como meio de assegurar a formação de um estado cuja autoridade pode ser considerada legitimada. Para Rousseau, a soberania não pode ser "repartida", pertencendo unicamente à sociedade civil. O autor distingue soberania e governo, denunciando um sentido "anti-republicano" nas

\footnotetext{
${ }^{55}$ SILVESTRINI, Gabriella. Diritto naturale e volontà generale: il contratualismo republicano di JeanJacques Rousseau. Torino: Claudiana, 2010, pg. 10 e ss.

${ }_{56}$ HABERMAS, Jürgen. Direito e Democracia: entre facticidade e validade, v. II, tradução de Flávio Siebeneichler. Rio de Janeiro: Tempo Brasileiro, 2011, pg. 201.

${ }^{57}$ ROUSSEAU, Jean-Jacques. Ibidem, pg. 9.

${ }^{58}$ ROUSSEAU, Jean-Jacques. Ibidem, pg. 13.

${ }^{59}$ ROUSSEAU, Jean-Jacques. Ibidem, pg. 20.
} 
compreensões jusnaturalistas que partiam do pressuposto de uma soberania “compartilhada" entre governo e povo ${ }^{60}$.

Assim, tendo em vista o seu conceito de soberania, o pressuposto para a reorganização social proposta por Rousseau é a integração social das vontades individuais, a partir de um pacto político, de modo que cada um, unindo-se a todos, só obedeça, contudo, a si mesmo e permaneça tão livre quanto antes ${ }^{61}$. A participação do indivíduo na vida política é, ao mesmo tempo, uma nova faceta da manifestação de sua personalidade e condição de sua liberdade privada, pois é pela sua vontade que se legitimarão o direito e o poder do estado. A vontade é, ao mesmo tempo, constitutiva da vida pública e instância de controle do resultado da elaboração legislativa.

Esta separação clara entre o âmbito estritamente individual e as responsabilidades políticas do indivíduo é o que fornece um caráter republicano à teoria contratualista de Rousseau, uma vez que a vontade de todos é conceitualmente distinta da vontade geral ${ }^{62}$. Esta surge como o resultado de um corpo político organizado, legitimado pelo consentimento dos indivíduos e cuja função é garantir o estado de liberdade.

Distinguindo a república da monarquia, define o autor como republicano qualquer governo guiado pela vontade geral ${ }^{63}$, que, por si só, é capaz de garantir sua legitimidade. Por isso afirma o filósofo:

Imediatamente, em vez da pessoa particular de cada contratante, esse ato de associação produz um corpo moral e coletivo composto de tantos membros quantos são os votos da assembleia, o qual recebe, por esse mesmo ato, sua unidade, seu eu comum, sua vida e sua vontade. ${ }^{64}$

É especialmente esclarecedora esta passagem, pois a unidade do corpo político proposta por Rousseau, esse "eu comum" distinto do eu individual dos atores políticos o distancia das teorias liberais clássicas, ao introduzir o conceito de coisa pública, de bem comum, a separação fundamental entre interesse público e interesse privado que é o cerne do Direito Público moderno.

60 SILVESTRINI, Gabriella. Rousseau, Pufendorf and the eighteenth-century natural law tradition. In: History of European ideas, n. 36, 2010, pg. 296.

${ }^{61}$ ROUSSEAU, Jean-Jacques. Op. cit.

${ }^{62}$ Segundo o autor francês, a vontade de todos diz respeito aos interesses privados, sendo uma soma das vontades particulares, enquanto a vontade geral se refere unicamente ao interesse comum, à coisa pública, portanto. Cf. ROUSSEAU, J.J. Ibidem., pg. 37.

${ }^{63}$ ROUSSEAU, Jean-Jacques. Ibidem, pg. 48.

${ }^{64}$ ROUSSEAU, Jean-Jacques. Ibidem, pg. 22. 
O autor francês propõe que a soberania política está estritamente vinculada ao pacto social fundado pela vontade dos indivíduos, pois só a vontade geral pode dirigir as forças do Estado em conformidade com o objeto de sua instituição, que é o bem comum ${ }^{65}$. Insuscetível de alienação ou divisão, a soberania garante que as leis produzidas pela assembleia sejam apenas emanações da vontade geral, sustentando sua legitimidade. Desse modo:

\begin{abstract}
Assim como a natureza dá a cada homem um poder absoluto sobre todos os seus membros, o pacto social dá ao corpo político um poder absoluto sobre todos os seus, e é esse mesmo poder que, dirigido pela vontade geral, recebe, como ficou dito, o nome de soberania. ${ }^{66}$
\end{abstract}

É preciso reconhecer que a teorização proposta por Rousseau foi fundamental para o desenvolvimento da teoria do poder constituinte. Ao reconhecer que o estado monárquico é um estado caduco por desrespeitar a soberania do corpo político unido pelo contrato social, faz-se necessário refundar a ordem estatal a partir da criação de uma nova constituição, a qual será, por sua vez, responsável pela positivação do ideário revolucionário. A constituição assume a função simbólica de tornar realidade a proposta filosófica da Ilustração, que busca assegurar um espaço de autonomia e liberdade ao indivíduo pelo reconhecimento de uma dignidade intrínseca à personalidade.

Isso porque, para Rousseau, as leis não são, em verdade, senão as condições da associação civil $^{67}$. A garantia de liberdade mantida pelo pacto social assegura que somente pela decisão do corpo político a liberdade individual será restringida, em face de uma decisão legitimada pela busca do bem comum. Desse modo, propõe o filósofo que: quando cada cidadão nada é e nada pode senão com todos os outros, e quando a força adquirida pelo todo é igual ou superior à soma das forças naturais de todos os indivíduos, pode dizer-se que a legislação está no mais alto grau de perfeição ${ }^{68}$.

O autor propõe uma teoria filosófica capaz de justificar o modelo democrático, estabelecendo um critério de legitimação do poder baseado na convenção. Pelo contratualismo, tem-se uma mudança na compreensão de quem é o titular do poder soberano e sobre quais são os limites de seu exercício. Em outras palavras, o autor busca oferecer uma alternativa de legitimação para as normas jurídicas a partir da mudança de paradigma na titularidade da soberania.

\footnotetext{
${ }^{65}$ ROUSSEAU, Jean-Jacques. Ibidem, pg. 33.

${ }^{66}$ ROUSSEAU, Jean-Jacques. Ibidem, pg. 39.

${ }^{67}$ ROUSSEAU, Jean-Jacques. Ibidem, pg. 48.

${ }^{68}$ ROUSSEAU, Jean-Jacques. Ibidem, pg. 50.
} 
Entendida como poder absoluto, invencível e irrestrito, a soberania do estado é, no modelo republicano proposto por Rousseau, uma decorrência da integração dos indivíduos promovida pelo contrato social, de modo que somente os homens reunidos livremente são obrigados a se submeter a lei: uma lei por eles criada nos limites de seus interesses comuns. Esse é o sentido extraído por Goyard-Fabre do texto de Rousseau, já que $a$ natureza da soberania só pode derivar do procedimento contratual segundo o qual a multidão, unanimemente, substitui as vontades particulares pela vontade geral: a essência da soberania se identifica, então, com a vontade geral ${ }^{69}$.

A breve análise da obra de Locke e Rousseau é capaz de mostrar a importância significativa que a escola contratualista da filosofia política teve para o desenvolvimento do constitucionalismo, seja na tradição de common law, seja na matriz europeia-continental do civil law. O surgimento do Estado de Direito Constitucional, seja histórico ou ideológico, coincide com o desenvolvimento de uma consciência cultural da autonomia da vontade individual, que se impõe soberanamente em face do poder político. Essa parece ser a nota distintiva do modelo político-jurídico forjado pelos estados nacionais na Modernidade. De acordo com a análise de Diniz,

O pensamento político da Ilustração significou a emergência de um novo paradigma a partir do qual a sociedade fez novas reflexões sobre as relações de poder e sobre o exercício legítimo da autoridade. Esta reviravolta representou a passagem de um horizonte objetal para um horizonte subjetal, onde a racionalidade contemplativa cedeu lugar a uma racionalidade instrumental. $^{70}$

No horizonte subjetal, os indivíduos reconhecem a força criadora da vontade e sua condição de sujeitos. A refundação da ordem política a partir do consenso de indivíduos livremente associados só pode ser concebida em um ambiente onde o sujeito é livre para criar e transformar as estruturas sociais a partir de seus interesses. A mudança no modelo de organização política apresenta-se como uma consequência de uma transformação filosófica e ideológica, a partir de um discurso construído através das obras dos autores do iluminismo.

Sieyès, segundo Goyard-Fabre ${ }^{71}$, foi capaz de medir o alcance inovador da mensagem da Ilustração francesa. $\mathrm{O}$ autor francês da obra fundamental dos estudos sobre teoria do poder constituinte, "O que é o Terceiro Estado?”, incorporou em seu discurso

${ }^{69}$ GOYARD-FABRE, Simone. Ibidem, pg. 180.

${ }^{70}$ DINIZ, Márcio Augusto de Vasconcelos. O Princípio de Legitimidade do Poder no Direito Público Romano e sua Efetivação no Direito Público Moderno. Rio de Janeiro: Renovar, 2006, pg. 274.

${ }^{71}$ GOYARD-FABRE, Simone. Ibidem, pg. 181. 
político e filosófico a retórica contratualista desenvolvida por Rousseau, substituindo o conceito de povo pela ideia de nação. No tópico subsequente, analisam-se os aspectos principais sobre a contribuição de Sieyès para o conceito de poder constituinte moderno, indicando o surgimento histórico e os pontos principais de sua obra.

2.3 O Terceiro Estado e o Poder Constituinte: A Teoria de Sieyès e sua Recepção pela Doutrina Constitucionalista

$\mathrm{O}$ abade Emmanuel Sieyès nasce na França em 1748 é considerado o nome responsável pelo desenvolvimento do conceito moderno de poder constituinte. $\mathrm{O}$ contratualismo - e, especialmente, a construção teórica de Rousseau - são fundamentais para a compreensão do sentido moderno de poder constituinte. Na teorização de Sieyès em sua obra clássica “O que é o terceiro estado?”, considerada a elaboração primordial sobre a teoria do poder constituinte na Modernidade, é possível vislumbrar que a teoria do contrato social justifica a necessidade de que a Nação - verdadeira titular do poder - o exercite através da elaboração de uma nova constituição, condizente com os seus anseios e interesses.

Apesar de sua importância para o desenvolvimento da teoria do poder constituinte revolucionário, seus intérpretes chamam atenção para o fato de que Sieyès é quase sempre excluído do panteão de mestres a que pertencem nomes como Montesquieu, Rousseau, Constant e Tocqueville. Mannoni tenta explicar, atribuindo a falta de estudos sobre o autor ao fato de que Sieyès não deixou tratados sistemáticos ou obras de grande erudição. Não alcançou a glória destinada aos intelectuais de grande consagração literária ou teve a proteção de um mecenato poderoso, pois se mostrava recolhido e obcecado por alcançar a mudança institucional almejada para o estado francês ${ }^{72}$.

Mannoni acredita que é tempo de atribuir a Sieyès o mérito de sua contribuição à história conceitual do direito público europeu. Isso porque, partindo de um núcleo coerente de premissas, a doutrina de Sieyès internaliza todas as tensões de seu tempo, sendo capaz de esclarecer boa parte das dúvidas acerca dos objetivos, valores e contradições da

\footnotetext{
${ }^{72}$ MANNONI, Stefano. La Dottrina Costituzionale di Sieyès. In: Quaderni Fiorentini: Per la Storia del Pensiero Giuridico Moderno, n.29, Milano, 2000, pg. 25.
} 
revolução ${ }^{73}$. Segundo o intérprete italiano, nenhuma teoria esteve tão ligada à experiência viva da revolução, nos seus momentos mais criativos e trágicos.

A construção teórica de Sieyès parte da afirmação jusnaturalista dos direitos do homem, materializada na declaração. A libertação dos indivíduos dos laços feudais os restituiu sua liberdade natural, o que teve como resultado a possibilidade de criação artificial de uma nova ordem jurídica a partir da vontade do povo francês ${ }^{74}$.

Ao contrário da perspectiva rousseauniana, que só conhece a soberania popular como participação direta na democracia, Sieyès oferece uma alternativa política baseada na representação. Sua doutrina tem como ponto de convergência, no dizer de Manonni, três tradições: a reflexão da filosofia política clássica sobre a seleção dos melhores; o discurso fisiocrático-iluminista sobre a representação dos interesses e sobre a deliberação racional e a nova instituição da divisão do trabalho como princípio-guia da organização econômico-constitucional ${ }^{75}$.

Reconhece Sieyès as dificuldades de instituição de uma democracia direta no contexto social da Europa do século XVIII, sendo elas de várias ordens: a falta de formação política dos indivíduos, a necessidade de dedicação às atividades econômicas de produção, a ausência de interesse direto na participação dos negócios públicos. Fundamental, portanto, para a ordem constitucional pós-revolucionária, que se estruture um corpo assemblear formado por uma classe profissional de representantes políticos. Sieyès não compartilha da ideia difundida entre os republicanos radicais de que a governo representativo é um mal necessário. Ele crê que o governo é um instrumento útil e precioso, desde que bem constituido ${ }^{76}$.

Compreendendo que a revolução deve ter como consequência fundamental a criação de uma nova ordem estatal, com instituições e regras de participação condizentes com o anseio da burguesia, desenvolve Sieyès o conceito de poder constituinte como manifestação da soberania da nação.

Para Sieyès, seria o poder constituinte a potência capaz de criar uma nova ordem jurídica, de rompimento com a anterior, cujo resultado é a criação do texto constitucional.

\footnotetext{
${ }^{73}$ MANNONI, Stefano. Ibidem., pg. 27.

${ }^{74}$ MANNONI, Stefano. Ibidem., pg. 28.

${ }^{75}$ MANNONI, Stefano. Ibidem, pg. 35.

${ }^{76}$ MANNONI, Stefano. Ibidem, pg. 50.
} 
É o poder constituinte, nesse sentido, um poder revolucionário, pois seu exercício é condicionado à mudança do fundamento de validade do ordenamento jurídico. Carré de Malberg identifica Sieyès com o grande teórico da soberania constituinte do povo, ao estabelecer que tal soberania se manifesta na forma de um poder constituinte:

\begin{abstract}
Ao mesmo tempo em que colocava, de forma incontestável, o poder constituinte nas mãos do povo, Sieyés - que, comungando do espírito de sistematização lógica próprio dos homens da Revolução, unia uma visão muito clara dos problemas e necessidades políticas daquela época a um sentido muito prático das soluções úteis - admitia, inclusive em matéria constituinte, a aplicação do regime representativo, ao qual concedia amplo lugar em seu plano de reorganização política. ${ }^{77}$
\end{abstract}

Para Sieyès, a "soberania do povo" se confunde com a "soberania nacional". O francês introduz a noção de representação como constitutiva do exercício da soberania, através da figura do mandato. $\mathrm{O}$ autor estabelece uma forma de representação nacional tal que os eleitos sejam independentes dos eleitores e só recebam seus poderes da Constituição $^{78}$. O direito ao voto tem o seu exercício restrito, portanto, à escolha do representante, que assume, no momento da investidura, uma importância e vontade próprias, autônomas dos anseios do representado. É nessa transição que a soberania popular se converte em soberania nacional.

Pasquino, em análise dos manuscritos do abade, identifica a influência dos estudos em economia política desenvolvidos por Sieyès entre os anos de 1770 e 1785 sobre sua visão de estado e sociedade. Os escritos de Sieyès manifestam, no dizer de Pasquino, não apenas conceitos, mas tomadas de decisão sobre uma forma de governo adequada ${ }^{79}$ para as sociedades comerciais da Modernidade, identificada com o modelo representativo.

Considerando imprópria a inspiração política das sociedades antigas, por falta de semelhança, Sieyès se propõe a analisar a especificidade da sociedade moderna, influenciada pela intensificação do comércio e pela divisão do trabalho - considerando este o próprio princípio da societé commerçante. A generalização do trabalho, o crescimento das manufaturas e da complexidade e diversidade das funções são identificados por Sieyès

\footnotetext{
${ }^{77}$ MALBERG, Carré de. Teoría General del Estado. México: Faculdad de Derecho/UNAM, 2000, pg. 1.165 .

${ }^{78}$ GOYARD-FABRE, Simone. Ibidem, pg. 184.

${ }^{79}$ PASQUINO, Pasquale. Emmanuel Sieyès, Benjamin Constant et le "gouvernement des modernes". Contribution à l'histoire du concept de répresentation politique. In: Revue Française de Science Politique, Ano 37, nº 2, 1987, pg. 214-229.
} 
como o motor de desenvolvimento da sociedade burguesa, sendo o modelo representativo aquele que melhor se adapta a essa dinâmica de organização social ${ }^{80}$.

Para Sieyés, o modelo de um governo mediato, na qual esteja conservada uma distância entre os que governam e os que são governados representa um considerável avanço em relação às sociedades antigas, nas quais os indivíduos eram chamados a participar diretamente dos assuntos públicos - que, na visão de Sieyès, só era possível graça à existência de uma classe de escravos destinados à produção da riqueza ${ }^{81}$. Em uma sociedade comercial, na qual o crescimento demográfico e a divisão das profissões e ofícios estão presentes, o governo representativo torna possível ao indivíduo dedicar-se às suas tarefas particulares, sem a urgência na participação das decisões fundamentais do estado.

O representante, portanto, libera o indivíduo para que possa trabalhar, reconhecendo que a existência de uma classe profissional de representantes legislativos é um sintoma do crescimento da sociedade e do incremento da complexidade social. A compreensão de Sieyès sobre como os aspectos econômicos influenciam a dinâmica social são, portanto, determinantes para o surgimento de sua teoria sobre o poder constituinte, na qual é possível vislumbrar a participação decisiva dos representantes na positivação da vontade da nação. Nas palavras do abade os trabalhos particulares e as funções públicas são os motores responsáveis por uma nação próspera ${ }^{82}$.

Segundo Pasquino, que compartilha a opinião de Manonni, a influência de Sieyès na França não foi significativa, especialmente na comparação com o impacto ideológico que as obras de Montesquieu e Rousseau provocaram no ideário revolucionário ${ }^{83}$. Apesar disso, a teoria constitucionalista de matriz europeia identifica a obra de Sieyès como um marco nos estudos sobre o poder constituinte, conforme salienta Paulo Bonavides: dá-nos testemunho Sieyès ao jactar-se no debate constitucional do Ano III de haver feito a Ciência progredir com a "descoberta" desse conceito, extraído das páginas de sua monografia sobre o terceiro estado ${ }^{84}$.

\footnotetext{
${ }^{80}$ PASQUINO, Pasquale. Ibidem, pg. 221.

${ }^{81}$ PASQUINO, Pasquale. Ibidem, pg. 225.

${ }^{82}$ SIEYĖS, E. J. Qu'est-ce que le tiers état? Paris, 1789, pg. 5.

${ }^{83}$ PASQUINO, Pasquale. Sieyès et l'invention de la Constitution en France. Paris: Éditions Odile Jacob, 1998, pg. 9.

${ }^{84}$ BONAVIDES, Paulo. Curso de Direito Constitucional. São Paulo: Malheiros, 2004, pg. 142.
} 
Segundo Horta, no final do século XVIII, quando se concebeu a clássica doutrina desse poder, Sieyès já oferecia as características do criador da nova Constituição ${ }^{85}$. Embora sua visão sobre a sociedade e o poder possa ser extraída do conjunto de manuscritos de sua obra, é com a monografia "O que é o terceiro estado" que Sieyès não só apresenta como exorta os companheiros revolucionários ao exercício do poder constituinte.

A obra Qu'est-ce que le tiers état?, publicada na França em janeiro do ano de 1789, busca responder a três indagações apresentadas pelo autor já no primeiro capítulo: o que é o terceiro estado?; o que ele tem sido até o momento na ordem política?; o que ele almeja?. Na primeira parte da obra, Sieyès apresenta as principais funções e atividades econômicas distribuídas na sociedade, mostrando que a força produtiva está na concentrada na atividade da classe burguesa, identificada com o terceiro estado. Natural, portanto, que seja a classe burguesa - identificada como nação - a titularizar o poder legítimo, pois $o$ terceiro estado alcança tudo o que pertence à nação; e tudo que não faz parte do terceiro estado não pode ser considerado como pertencente à nação. O que é o terceiro estado? Tudo. $^{86}$

Segundo o raciocínio de Sieyès, a condição de liberdade dos indivíduos é a previsão de direitos e não de privilégios, tradicionalmente associados à nobreza aristocrática ${ }^{87}$. Para o francês:

\begin{abstract}
Sigamos o nosso argumento. Entenda-se por terceiro estado o conjunto de cidadãos que pertencem à ordem comum. Todo aquele que é privilegiado pela lei, de qualquer modo que o seja, sai da ordem comum, fazendo-lhe exceção, e, consequentemente, não faz parte do terceiro estado. ${ }^{88}$
\end{abstract}

Constata-se na retórica de Sieyès uma tentativa clara que fundamentar a mudança na ordem política, representada pela destituição da monarquia e pela consolidação do governo republicano. Naquele período da história, reconhece o abade que o terceiro estado não teve verdadeiramente representantes nos poderes estatais, razão pela qual seus direitos políticos são nulos $^{89}$, ineficazes.

O povo, assim, quer ser alguma coisa, entendida como representação nos poderes instituídos ${ }^{90}$. Neste ponto, Sieyès cuida de apresentar uma visão embrionária do critério de

\footnotetext{
${ }^{85}$ HORTA, Raul Machado. Direito Constitucional, $5^{\text {a }}$ edição. Belo Horizonte: Del Rey, 2010, pg. 3.

${ }^{86}$ SIEYĖS, E.J. Ibidem, pg. 14.

${ }^{87}$ SIEYĖS, E.J. Ibidem, pg. 18.

${ }^{88}$ SIEYÈS, E.J. Ibidem, pg. 18.

${ }^{89}$ SIEYÈS, E.J. Ibidem, pg. 27.

${ }^{90}$ SIEYÈS, E.J. Ibidem, pg. 28.
} 
representação majoritária, ao reconhecer a injustiça de que o valor dos votos seja igualmente distribuído entre as classes da nobreza, da igreja, e do povo. O entendimento do abade é que se mostra fundamental reconhecer que o voto tenha seu peso não pela ordem a que pertence, mas pela quantidade de votantes (par têtes et non par ordres) ${ }^{91}$.

O terceiro estado, então, apresenta como reivindicações que seus representantes sejam provenientes da própria classe; que o número de seus representantes seja equivalente ao das outras ordens; que o voto seja apreciado não pela ordem, mas por cabeça. Para alcançar tais objetivos, propõe Sieyès que é preciso fazer uma constituição, já que toda nação deve ser livre e tal liberdade é assegurada pela preservação do direito de eleger o representante. O modo de governo proposto pelo abade é, portanto, um governo por procuração, construído em face do conceito de vontade comum representativa ${ }^{92}$.

Para que o governo representativo seja instituído, mostra-se fundamental elaborar uma nova constituição, condizente com os anseios e princípios apresentados pelo abade em sua obra de exortação. Para Sieyès, é impossível criar um corpo para um fim sem dar-lhe uma organização, formas e leis próprias ao atendimento das funções que quisemos lhe atribuir. Eis o que chamamos a constituição desse corpo ${ }^{93}$. Tem-se um conceito instrumental de constituição, na medida em que sua elaboração está vinculada ao atendimento de determinados fins, em especial o dever de obediência dos governos à vontade da Nação.

No percurso argumentativo desenvolvimento pelo abade francês, a constituição tem a função de positivar normas associadas à segurança jurídica, na medida em que é possível encontrar uma multiplicidade de precauções políticas que se inseriu na constituição, as quais são regras essenciais ao governo, sem as quais o exercício do poder torna-se ilegal $^{94}$. A preocupação manifesta na obra é condizente com o temor burguês em relação ao estado, responsável histórico pela privação da liberdade econômica necessária à societé commerçante.

Sieyès faz questão de esclarecer que a nação é anterior ao governo, é o que lhe legitima a ação: trata-se a nação da origem de tudo ${ }^{95}$. Nesse sentido, o governo deve

\footnotetext{
${ }^{91}$ SIEYÈS, E.J. Ibidem, pg. 29.

${ }^{92}$ SIEYÈS, E.J. Ibidem, pg. 108.

${ }^{93}$ SIEYÈS, E.J. Ibidem, pg. 109.

${ }^{94}$ SIEYÈS, E.J. Ibidem, pg. 109.

${ }^{95}$ SIEYÈS, E.J. Ibidem, pg. 111.
} 
mostrar-se fiel à vontade da nação, manifesta por procuração através da vontade dos representantes eleitos, que não tem qualquer vinculação em relação às pretensões individuais dos eleitores. O mandato, portanto, pressupõe uma espécie de irresponsabilidade originária do mandatário, que não se obriga a consultar o interesse daquele que o investiu de poderes.

A vontade dos eleitores em uma bailliage ${ }^{96}$ é necessariamente uma vontade particular em relação à vontade da nação em sua totalidade, sublinhava Sieyès, razão pela qual um deputado, em sua qualidade de representante da nação, não pode jamais estar submetido a esta vontade particular ${ }^{97}$.

Considerando que o francês entende ser uma prova de desenvolvimento civilizatório a divisão do trabalho e a crescente especialização das funções, mostra-se natural que o representante - aquele que exerce profissionalmente a função de governar tem melhores condições de avaliar e gerir os assuntos do Estado. É por esse motivo que, no raciocínio do abade, uma vez eleito, o mandatário não pode ter sua autonomia restringida pela vontade dos eleitores.

O representante é responsável por manifestar a vontade da nação, uma vontade que se qualifica como sempre legal, como sendo a própria lei ${ }^{98}$. E a constituição, neste processo, é o conjunto de formas, procedimentos e limites que permite a manifestação da vontade no exercício dos poderes constituídos.

Nesse ponto, diferencia Sieyès o conceito de poder constituído - limitado, restringido pelas precauções políticas previstas na constituição - daquele de poder constituinte - originário, cujo exercício representa a positivação da vontade da Nação. A constituição - enquanto obra fundamental - é, no dizer do francês, a obra de um poder constituinte, um poder voltado à organização do governo. Um poder prévio, portanto.

Identifica Sieyès a reconstrução do estado nos modelos propostos pelo terceiro estado com o necessário exercício do poder constituinte, que originará a criação da constituição do governo da liberdade. A vontade do terceiro estado é ser qualquer coisa, sair da influência da opressão e das restrições que lhe impedem o pleno exercício de suas atividades econômicas e a sua participação nos assuntos legislativos.

\footnotetext{
${ }^{96} \mathrm{O}$ termo, sem um correlato próprio para o português, refere-se à divisão territorial administrativa da França ao tempo do processo revolucionário a que se faz referência neste texto, razão pela qual se optou por manter sua escrita no original.

${ }^{97}$ FURET, F.; OZOUF, M. et ali. Ibidem, pg. 196.

${ }^{98}$ SIEYÈS, E.J. Ibidem, pg. 111.
} 
Furet, Ozouf et ali esclarecem que foi Sieyès o responsável pela construção de um conceito positivo de constituição, diferente do conceito puramente histórico utilizado até então:

Sieyès, em verdade, atacou o sentido tradicional de constituição entendida como uma ordem social e política inerente à natureza das coisas e o substituiu pela noção de instituição de um governo. Em sua refutação aos argumentos dos privilegiados em favor do uso tradicional do termo, Sieyès foi levado a afirmar que a existência da nação como o cerne da realidade política, imediatamente presente e anterior a toda forma constitucional $^{99}$.

Sendo a nação a titular da vontade última, sempre legal, não se revela lógica a impossibilidade de mudança da constituição sob argumento de violação da ordem natural das coisas. É contra o argumento transcendente de um poder estabelecido para além da convenção que se insurgem Sieyès e toda a tradição filosófica da ilustração, em especial Rousseau. O contratualismo, assim como a teoria do poder constituinte manifesta por Sieyès, são tentativas de desconstrução de um argumento que associa a existência de privilégios a uma ordem insuperável, estabelecida pela natureza, insuscetível de mudanças provocadas pelo homem. Segundo Furet, Ozouf et ali, isto posto, não era possível sustentar que a nação estava presa a arranjos sociais ou políticos já existentes, em nome de uma constituição anterior ${ }^{100}$.

A função da constituição, dentro do processo revolucionário francês profundamente ligado a toda construção filosófica da Ilustração, era de criação. Segundo os intérpretes franceses:

Quando, no dia quatro de agosto, a Assembleia decidiu, quase por unanimidade, que a constituição seria precedida de uma Declaração de direitos, ela se afastou da ideia de uma constituição para preservar e optou claramente pela ideia de uma constituição para criar $^{101}$.

O simbolismo que assume a constituição, sua estreita relação com a afirmação de uma nova ordem política e com a preservação de direitos do homem e do cidadão, foi fundamental para o desenvolvimento da teoria constitucionalista moderna $\mathrm{e}$ contemporânea. O reflexo dessa nova forma de compreender a função do direito na organização da sociedade foi perceptível também em outras áreas de regulação, como o direito civil:

${ }^{99}$ FURET, François; OZOUF, Mona et ali. Dictionnaire critique de la révolution française: Institutions et Créations. Paris: Flammarion, 2007, pg. 185.

${ }^{100}$ FURET, F.; OZOUF, M. et ali. Ibidem, pg. 185.

${ }^{101}$ FURET, F.; OZOUF, M. et ali. Ibidem, pg. 187. 
Inspirando-se precisamente nas concepções de Rousseau e iluministas em geral, os juristas da Revolução Francesa se propuseram a eliminar o acúmulo de normas jurídicas produzidas pelo desenvolvimento histórico e instaurar no seu lugar um direito fundado na natureza e adaptado às exigências universais humanas. ${ }^{102}$

A transformação não se restringiu à França. O artigo 16 da Carta Constitucional francesa de 1791 foi incorporado não apenas à ordem jurídica pós-revolucionária, mas ao próprio ideário político dos estados nacionais nascidos à luz do liberalismo francês.

Segundo esse dispositivo, toda sociedade em que não estejam garantidos os direitos nem a separação dos poderes não possui uma constituição. Tem-se, portanto, um conceito material de constituição capaz de superar o sentido histórico utilizado retoricamente pelos monarquistas. O exercício do poder constituinte e a construção de uma nova constituição vieram, portanto, para fazer valer o artigo $6^{\circ}$ da Declaração dos Direitos do Homem, que estabelecia ser a lei a expressão da vontade geral, em clara recepção ideológica da contribuição de Rousseau ${ }^{103}$. Desse modo, tem-se que dito artigo parecia implicar claramente a necessidade de criar uma constituição que assegurasse a expressão direta da vontade geral $^{104}$. Tem-se gestado o sentido moderno de constituição e sua estreita relação com o necessário exercício do poder constituinte.

O sentido instrumental de constituição é explicado por Bercovici, nos seguintes termos:

O Estado é pressuposto pela constituição, cuja função é regular os órgãos
estatais, seu funcionamento e esfera de atuação, o que irá,
consequentemente, delimitar a esfera de liberdade individual dos
cidadãos. A constituição é também um instrumento de governo, pois
legitima procedimentalmente o poder, limitando-o. ${ }^{105}$

Bercovici chama atenção para o fato de que o sentido moderno de constituição como norma fundamental de estruturação do Estado passou por uma transformação significativa ao longo do século XX. Isso porque as cartas constitucionais, segundo o autor, assumem conteúdo político, ou seja, englobam os princípios de legitimação do poder, não apenas sua organização ${ }^{106}$. Nesse sentido, tem-se, após a segunda guerra mundial, um

\footnotetext{
${ }^{102}$ BOBBIO, Norberto. O positivismo jurídico: lições de filosofia do direito, tradução de Márcio Pugliesi et ali. São Paulo: Ícone, 2006, pg. 65.

${ }^{103}$ FURET, F.; OZOUF, M. et ali. Ibidem, pg. 188.

${ }^{104}$ FURET, F.; OZOUF, M. et ali. Ibidem, pg. 188.

${ }^{105}$ BERCOVICI, Gilberto. Constituição e Política: Uma relação difícil. In: Luanova, nº 61, 2004, pg. 6.

${ }^{106}$ BERCOVICI, G. Ibidem, pg. 9.
} 
conceito de constituição como totalidade e o desenvolvimento de um conceito de estado democrático de direito $^{107}$.

Em sua análise, Bercovici esclarece não ser a relação entre democracia e constituição própria do ideário revolucionário dos séculos XVIII e XIX. A tentativa, nem sempre bem sucedida, de conciliar o constitucionalismo com a democracia vai, na Europa, ter início com a Constituição alemã de 1919, a célebre Constituição de Weimar ${ }^{108}$.

Apesar disso, é possível vislumbrar que, com a contribuição teórica de Sieyès, desenvolve-se uma necessária implicação entre constituição e sistema representativo, dentro do intento revolucionário de superação da monarquia e refundação do Estado no formato de um estado de direito liberal.

Não apenas no que tange à democratização do poder, verifica-se o nascimento da positividade da constituição como construção cultural. No dizer de Laquièze, tem-se com, a obra $O$ que é o terceiro estado?, uma perfeita ilustração do princípio segundo o qual uma nação tem o direito de modificar a constituição ${ }^{109}$, quando comenta a importância que teve Sieyès para o desenvolvimento da doutrina publicista francesa dos séculos seguintes.

Laquièze não deixa de chamar atenção para as dificuldades metodológicas de se reconhecer que o pensamento de determinado filósofo foi "recepcionado" ou "transmitido" para os tempos seguintes ${ }^{110}$. Apesar disso, entende o francês não ser relevante analisar se o autor foi bem compreendido pelos seus intérpretes, mas as razões pelas quais ele foi utilizado discursivamente:

\footnotetext{
O estudo da recepção do pensamento de um autor não se refere à questão de saber se o ou os receptores compreenderam bem a mensagem do emissor, mas serve, sobretudo, para determinar porque eles o utilizaram, porque eles decidiram enfocar determinados pontos de sua obra em vez de outros, porque cada um deles fez prevalecer uma interpretação diferente das precedentes. ${ }^{111}$
}

A consideração de Laquièze mostra-se importante, na medida em que Sieyès vem sendo utilizado pela doutrina constitucionalista como o pensador original da teoria do poder constituinte liberal. Em que pese as diferenças consideráveis entre o contexto

\footnotetext{
${ }^{107}$ BERCOVICI, G. Ibidem, pg. 9.

${ }^{108}$ BERCOVICI, G. Ibidem, pg. 6.

${ }^{109}$ LAQUIEZE, Alain. La réception de Sieyès par la doctrine publiciste française du XIXème et du XXème siècles. In: Revista Electrónica de Historia Constitucional, nº 6, 2005, pg. 230.

${ }^{110}$ LAQUIEZE, A. Ibidem, pg. 233.

${ }^{111}$ LAQUIEZE, A. Op. cit.
} 
histórico da França na revolução do século XVIII e o momento vivido pelos estados constitucionais desde o pós-guerra, as doutrinas constitucionalistas cuidam de reproduzir com rigor os postulados da incondicionalidade e limitação inicial do poder constituinte originário, como verdadeiro dogma.

Para Tavares, a importância de Sieyès na teoria constitucional moderna, no que tange ao conceito de poder constituinte, deve-se, sobretudo, à definição de suas funções: a instrumentalização da separação de poderes e a positivação dos direitos e garantias individuais $^{112}$.

A importância do autor parece advir do fato de que Sieyès foi capaz de propor um modelo de organização do poder que conciliasse a garantia das liberdades individuais, a separação dos poderes e o direito ao voto em uma sociedade já marcada pela complexidade e pela desintegração. Através do conceito de governo "por procuração" e das suas explicações sociológicas sobre a divisão do trabalho, Sieyès incorpora o cidadão nos assuntos políticos de forma limitada, restringindo sua participação à eleição do representante. Trata-se, como esclarece Laquièze, de uma soberania nacional, mas uma soberania marcada pela limitação ${ }^{113}$.

112 TAVARES, André Ramos. Reflexões sobre a Legitimidade e as Limitações do Poder Constituinte, da Assembleia Constituinte e da Competência Constitucional Reformadora. In: Cadernos de Direito Constitucional e Ciência Política, São Paulo, Revista dos Tribunais, n. 21, out./dez., 1997, pg. 222.

${ }^{113}$ LAQUIEZE, A. Ibidem, pg. 234. 


\section{A TEORIA CLÁSSICA DO PODER CONSTITUINTE}

No capítulo anterior, foi apresentada, a título de pressuposto teórico, uma breve análise das contribuições da filosofia política nascida do constitucionalismo liberal para o desenvolvimento da teoria do poder constituinte, notadamente após a publicação da obra de Emmanuel Joseph Sieyès. Ao longo dos séculos XIX e XX, a teorização de Sieyès sofreu adaptações e mudanças, que acompanham as transformações vividas pelo Estado de Direito liberal. É possível perceber, todavia, que um núcleo conceitual é mantido e que uma teoria clássica do poder constituinte tem se mantido viva nas obras dogmáticas sobre o direito constitucional nos países herdeiros do civil law.

É caracterizado como clássico (ou liberal) o arcabouço teórico construído pelos autores que utilizam o paradigma de Sieyès e dos contratualistas franceses como marco da teoria do poder constituinte da Modernidade ${ }^{114}$. Em que pese a importância do movimento revolucionário norte-americano para consolidação do estado constitucional no mundo ocidental, é inegável que a matriz teórica desenvolvida na França encontrou na doutrina constitucionalista brasileira uma herdeira importante. Nos subtópicos destinados à definição sobre o poder constituinte, em que se analisará a bibliografia francesa, brasileira e portuguesa, ficará evidente a influência dos autores franceses nas publicações dos países lusófonos.

Segundo Krol, Sieyès e Carl Schmitt foram os autores que mais diretamente inspiraram a doutrina clássica sobre poder constituinte, compreendendo-se por clássica a teoria nascida do movimento constitucionalista moderno ${ }^{115}$ e da influência dos contratualistas. Carré de Malberg, ao apresentar a teoria do poder constituinte, chama

\footnotetext{
${ }^{114}$ Cf. SALGADO, Gisele M. O Poder Constituinte: Um Paralelo entre a Visão da Teoria Política Clássica e o Direito Positivo da Atualidade. In: Revista de Direito Constitucional e Internacional, São Paulo, RT, 2007, v 15, n.60, pg. 126.

${ }^{115}$ KROL, Heloísa da S. Limites Materiais ao Poder Constituinte Originário: Uma Releitura da Teoria Constitucional a partir da noção de Direitos Humanos Universais. In: Revista dos Tribunais, v. 96, n. 861, 2007, São Paulo, pg. 36.
} 
atenção para o fato de que nesta teoria se reconhecem os princípios característicos da doutrina do Contrato Social ${ }^{116}$. Isso porque, segundo o publicita francês,

A ideia geral que aparece no fundo de toda esta argumentação é a de que a
Constituição é o ato mediante o qual os cidadãos concordam em fundar o
Estado por meio da criação da organização nacional, sendo, portanto, um
ato contratual. Também se pode concluir que toda nova constituição
constitui uma espécie de novo contrato social, contrato em cuja renovação
é necessário que cada membro da nação intervenha de maneira efetiva,
com o fim de provocar, mediante o consentimento de todos, a
reorganização da associação nacional. ${ }^{117}$

Canotilho, ao definir o poder constituinte como conceito limite do direito constitucional nacional ${ }^{118}$, chama atenção para o "reducionismo" da abordagem clássica. Isso porque a problemática da gênese do poder constituinte era abordada tendo sobretudo em vista o chamado paradigma do "pouvoir constituant" da Revolução Francesa. Segundo o português, o ponto de partida era redutor porque esquecia dois outros momentos de gestação das normas básicas: o constitucionalismo inglês e o constitucionalismo americano $^{119}$.

Apesar da importância histórica das matrizes inglesa e americana sobre os estudos acerca do poder constituinte, é inegável que a influência da revolução francesa sobre o constitucionalismo europeu sobressaiu, inclusive quanto às referências doutrinárias utilizadas pelos juristas dos países-herdeiros, colonizados pelas metrópoles europeias, como é o caso do Brasil. O pensamento constitucional da Europa no século XIX é, como diz Saldanha, fortemente impregnado pelo timbre racionalista-leigo-burguês, e se define como uma resultante da formação do Estado de Direito moderno ${ }^{120}$, sendo o modelo de experiência revolucionário-constitucional da França o mais influente de $\operatorname{todos}^{121}$. Para Saldanha:

Um tanto porque a França, quando da Revolução, vinha de seu apogeu
(Spengler mesmo chegou a escrever a cultura ocidental durante o século
dezessete foi cultura francesa). Um tanto porque ela estava no próprio
cerne do continente europeu - não numa ilha à parte nem do outro lado do
oceano -, e, portanto, no palco mais visível para as evidências históricas
e a persuasão ou influência. E um tanto porque os componentes da

\footnotetext{
${ }^{116}$ MALBERG, Carré de. Teoría General del Estado. México: Faculdad de Derecho/UNAM, 2000, pg. 1.163.

${ }^{117}$ MALBERG, Carré de. Ibidem., pg. 1.163.

${ }^{118}$ CANOTILHO, J. J. G. Direito Constitucional e Teoria da Constituição, $7^{\text {a }}$ ed. Coimbra: Almedina, 2003, pg. 67.

${ }_{119}^{119}$ CANOTILHO, J. J. G. Ibidem, pg. 68.

${ }^{120}$ SALDANHA, Nelson. Formação da Teoria Constitucional, $2^{\mathrm{a}}$ edição. Rio de Janeiro: Renovar, 2000, pg. 20.

${ }_{121}^{11}$ SALDANHA, Nelson. Ibidem, pg. 68.
} 
Revolução francesa, que foi também revolução constitucionalizante, se universalizaram de modo especial, se apresentaram exemplares e modelares aos olhos do mundo. ${ }^{122}$

A "universalização" que menciona Saldanha deve ser compreendida dentro de uma perspectiva eurocêntrica, isto é, significa a capacidade de influência ideológica, despertando movimentos políticos semelhantes em países herdeiros da tradição jurídica e cultural da Europa, como o Brasil. Não se pode entender a revolução cultural vivida na Modernidade no continente europeu como uma revolução mundial, no sentido que a universalização mencionada por Saldanha pode sugerir.

É evidente a importância do trabalho de sistematização operado pelos publicistas franceses, desde a Revolução, para a disseminação das suas ideias e do ideário do movimento constitucionalista, razão pela qual se mantém, como referencial teórico para a análise do poder constituinte, neste trabalho, a teoria considerada clássica. Percebe-se que os conceitos, as definições e as classificações sobre o poder constituinte, além das teorizações sobre o seu exercício, seguem o modelo formulado pela escola liberal ilustrada por Sieyès, identificado como o primeiro criador de uma teoria sobre o poder constituinte.

O próprio Canotilho, que denuncia a abordagem reducionista, reconhece ter a revolução francesa transportado dimensões complemente novas quanto ao tema, o que revela sua importância histórica ${ }^{123}$.

Neste capítulo, busca-se apresentar os principais postulados da teoria clássica do poder constituinte, a partir do levantamento bibliográfico da doutrina publicista francesa, portuguesa e brasileira, bem como das contribuições ao conceito de poder constituinte trazidas pelo alemão Carl Schmitt, por ocasião da publicação da obra Teoria da Constituição (Verfassungslehre).

O filósofo alemão teve uma importância significativa para incorporação do elemento voluntarista ao conceito geral sobre o poder constituinte, ao definir a constituição como uma vontade política triunfante, apresentando um contraponto interessante à teoria clássica, já no século XX, que representou o surgimento de problemas políticos e jurídicos de proporções até então desconhecidas no mundo europeu.

\footnotetext{
${ }^{122}$ SALDANHA, Nelson. Ibidem, pg. 68.
}

${ }^{123}$ CANOTILHO, J. J. G. Ibidem, pg. 71. 


\subsection{Definições de Poder Constituinte}

Começa-se o trabalho de apresentação das definições de poder constituinte pelas elaborações francesas, por força de sua influência teórica e ideológica já apresentada no tópico anterior. Pela definição do termo, os autores delimitam o conceito utilizado em seu argumento, indicando, ainda que implicitamente, suas preferências ideológicas e o referencial teórico que compartilham.

O objetivo específico deste tópico não é relacionar em detalhes todas as definições sobre poder constituinte existentes na produção jurídica de matriz europeia-continental, trabalho que se mostraria árduo e infrutífero para o objetivo principal desta tese, que se propõe a construir uma teoria propositiva sobre o poder constituinte democrático. $\mathrm{O}$ objetivo específico aqui é apresentar as proposições clássicas e analisá-las criticamente em suas debilidades e seus acertos, a fim de avançar na proposta que se estrutura nestas páginas.

Por essa razão, optou-se por selecionar autores que se destacam na literatura e cujas obras tiveram por efeito principal influenciar a adoção por outros autores dos conceitos e ideias nelas manifestos. Em outras palavras, analisou-se a permeabilidade da obra, sua aceitação pela comunidade científica e a difusão como critérios para seleção dos autores cuja definição se analisa.

É preciso salientar, todavia, que a aceitação e a difusão de uma obra nem sempre aparecem como resultado de propostas teóricas criativas ou racionalmente justificadas. No que tange aos estudos sobre poder constituinte, observa-se uma clara dificuldade dos doutrinadores jurídicos em defini-lo em termos rigorosos, em apresentar características uniformes ou organizar sua forma de expressão, dada a observação empírica de que, do ponto de vista fático, cada processo constituinte é único, próprio da sociedade e do contexto histórico em que surge. É justamente a dificuldade em classificar o poder constituinte dentro dos parâmetros dogmáticos tradicionais que faz com que os autores o apresentem como tema próprio da sociologia jurídica.

Após investigar os aspectos principais das definições apresentadas, será possível concluir em que ponto se assemelham, se há alguma originalidade nas propostas 
doutrinárias e até onde tais definições se mostram sustentáveis do ponto de vista da ciência racional.

\subsubsection{O Poder Constituinte em Georges Burdeau e Carré de Malberg}

O nome do publicista Georges Burdeau desponta entre os estudiosos do poder constituinte na França, por força do seu trabalho sistematizador apresentado na obra Traité de Science Politique ${ }^{124}$.

Partindo da distinção conceitual entre poder bruto (ou de fato) e poder jurídico, entendido este como competência, Burdeau reconhece a natureza híbrida do poder constituinte, na medida em que, como salienta o autor, a potência que o poder constituinte detém é "rebelde" a qualquer integração total em um sistema hierarquizado de normas e competências $^{125}$, ao mesmo tempo em que se define o poder constituinte como o poder inicial criador do próprio ordenamento jurídico ${ }^{126}$.

No seu trabalho de classificação, Burdeau apresenta a distinção já tradicional entre o poder constituinte e os poderes constituídos: enquanto estes se qualificam como poderes jurídicos, limitados e condicionados, o constituinte é um poder extra-estatal ${ }^{127}$. Os poderes constituídos são identificados como competências, potência de ação e decisão autorizada e delimitada pelo Estado através do direito.

O próprio conceito poder constituinte admite uma subclassificação, consistente na distinção entre o poder constituinte originário e poder constituinte derivado (ou instituído, para ser fiel à terminologia do autor). Para Burdeau, o poder constituinte instituído não pode jamais eliminar o poder constituinte originário. O estabelecimento daquele não implica que o soberano renunciou às suas prerrogativas constituintes ${ }^{128}$. O poder

\footnotetext{
${ }^{124}$ BURDEAU, Georges. Traité de Science Politique. Paris: Librairie Génerale de Droit et Jurisprudence, 1966.

${ }^{125}$ BURDEAU, Georges. Ibidem, pg. 171.

${ }^{126}$ As discussões de Burdeau sobre a natureza do poder constituinte - no sentido de responder à indagação sobre se o poder constituinte pode ser definido como poder jurídico - serão detalhadas no tópico seguinte, onde serão analisadas comparativamente as concepções doutrinárias sobre o tema.

${ }^{127}$ BURDEAU, Georges. Ibidem, pg. 172.

${ }^{128}$ BURDEAU, Georges. Ibidem, pg. 211.
} 
constituinte instituído nada mais é que o poder de revisão e reforma da constituinte, normalmente organizado pelo texto constitucional produzido pelo constituinte originário.

Nesse sentido, denomina-se igualmente poder constituinte a produção de emendas tendentes à atualização e modificação da carta constitucional promulgada ou outorgada, ainda que se reconheçam diferenças consideráveis no grau de liberdade atribuído ao exercício das duas categorias de poder: enquanto que o originário é a pura potência criadora e incondicionada, o instituído é um poder jurídico, isto é, "preso" às normas de procedimento.

O poder constituinte originário é, portanto, na compreensão de Burdeau, incondicionado, inicial e autônomo, uma vez que o soberano não está subordinado a qualquer norma sobre a forma ou o conteúdo do direito que pretende criar $^{129}$.

Em artigo publicado no ano de 1959, produzido por ocasião da constituição francesa de 1958, Burdeau apresenta uma releitura original sobre a concepção clássica de poder, ao estabelecer uma diferenciação entre o poder estatal e o poder democrático, os quais estariam latentes na sociedade, gerando um suposto paradoxo frente à tese da unidade da soberania ${ }^{130}$.

A fim de desfazer o aparente paradoxo, Burdeau reconhece a ambiguidade do conceito de povo. Burdeau tanto compreende o povo como a reunião de homens temporal e espacialmente situados, aqui marcados por diferenças culturais, anseios, valores inteiramente diversos e conflitantes (peuple d'hommes situés), como igualmente se pode compreender o povo no sentido atribuído pela tradição do direito público francês, que o conceitua como o conjunto dos cidadãos (l'ensemble des citoyens), conjunto marcado pela noção de unidade ${ }^{131}$.

Entendido o povo como “conjunto de cidadãos", já não se manifestam as diferenças de classe entre os indivíduos, ressaltando-se o seu caráter de membros da nação. A vontade do povo, entendido nesta acepção, corresponde à noção de volonté generale tal como desenvolvida por Jean-Jacques Rousseau ${ }^{132}$.

\footnotetext{
${ }^{129}$ BURDEAU, Georges. Ibidem, pg. 174.

${ }^{130}$ BURDEAU, Georges. La conception du pouvoir selon la Constitution du 4 octobre 1958. In: Revue de Science Politique, 1959, v.9, n. I, pg. 94.

${ }^{131}$ BURDEAU, Georges. Ibidem, pg. 95.

132 BURDEAU, Georges. Ibidem, pg. 95.
} 
Para Burdeau, o sentido clássico de povo como unidade homogênea é problemático, considerando-se a estrutura do estado partidário, onde os indivíduos são chamados a participar - votar - conforme suas preferências e desejos pessoais, materializados na proposta de governo do partido. A noção de uma entidade nacional abstrata, um compartilhamento homogêneo de interesses, é insustentável nas democracias do estado do bem-estar e já não se pode esperar a abnegação e o sentido de volonté generale comumente invocados no estado liberal.

O reconhecimento dessa nova categoria de povo, mais sociológica que ideal, marcada pela diversidade e pela complexidade, implicou o surgimento de um sentido novo de democracia, chamada por Burdeau de démocratie gouvernante. Aqui, a unidade nacional é possível graças ao desejo comum pelo bem-estar e não pelo compartilhamento de valores e ideais simbolizados na ideia de nação. Assim, enquanto que na democracia clássica o poder fundamenta sua energia na abnegação dos cidadãos, na democracia social é preciso buscá-la na vontade de bem-estar de uma coletividade infinitamente diversificada ${ }^{133}$.

As análises de Burdeau sobre a natureza do poder no estado partidário parecem ir ao encontro de uma nova compreensão sobre o poder constituinte, para além do conceito clássico desenvolvido pelo direito público francês.

O publicista Carré de Malberg insere seu estudo sobre o poder constituinte no arcabouço de sua teoria organicista ${ }^{134}$. O autor define o órgão como um indivíduo ou conjunto de indivíduos cuja vontade se transforma em vontade do estado, sendo proveniente da constituição. A carta constitucional é entendida como o instrumento por meio do qual o poder da nação pode ser exercido, na medida em que o direito positivo tem o condão de "comunicar" o poder aos diversos órgãos estatais ${ }^{135}$.

Fazendo referência ao contrato social de Rousseau e a uma compreensão democrática de poder constituinte, afirma Malberg:

O estatuto orgânico pelo qual uma pluralidade de homens, que pertencem a uma mesma nação, constitui-se em corpo estatal unificado deve logicamente ser obra destes mesmos homens. Em outras palavras, a

\footnotetext{
${ }^{133}$ BURDEAU, Georges. Ibidem, pg. 96, tradução livre.

${ }^{134}$ MALBERG, Carré de. Ibidem, pg. 1161.

${ }^{135}$ MALBERG, Carré de. Ibidem, pg. 1161.
} 
soberania primária, o poder constituinte, reside essencialmente no povo, na totalidade e em cada um de seus membros ${ }^{136}$.

Para Malberg, a formação inicial do estado, obra do poder constituinte originário, é um puro fato, insuscetivel de classificar em qualquer categoria jurídica, na medida em que tal fato não está submetido a princípios de direito ${ }^{137}$.

\subsubsection{O Poder Constituinte em Jorge Miranda e Joaquim Canotilho}

Como já explicado, não é o objetivo deste tópico realizar um levantamento bibliográfico exaustivo do que já se produziu em Portugal sobre o conceito e os limites do poder constituinte, mas de apresentar as definições principais da literatura jurídica portuguesa que encontraram maior repercussão e aceitabilidade no meio acadêmico nacional e europeu. Os nomes de Gomes Canotilho e Miranda despontam como os autores que tiveram maior permeabilidade no universo de referências no Brasil e, de certa forma, também entre os países de tradição romanística, razão pela qual se dará uma especial atenção à sua produção.

Canotilho apresenta o poder constituinte como soberania constituinte do povo, ou seja, o poder de o povo através de um ato constituinte criar uma lei superior juridicamente ordenadora da ordem política ${ }^{138}$. Implícito em seu conceito está a atribuição da titularidade do poder constituinte ao povo, estabelecendo-o como um poder essencialmente democrático.

Miranda traz em seu Manual de Direito Constitucional uma compreensão de poder constituinte como potencialidade constante, um poder que não se esgota na elaboração da constituição escrita, permanecendo latente em toda a existência do estado, pronto a emergir e a actualizar-se em qualquer instante ${ }^{139}$. Para o autor português:

Poder constituinte equivale à capacidade de escolher entre um ou outro rumo, nessas circunstâncias. E nele consiste o conteúdo essencial da soberania (na ordem interna), porquanto soberania significa faculdade

\footnotetext{
${ }^{136}$ MALBERG, Carré de. Ibidem, pg. 1163.

${ }^{137}$ MALBERG, Carré de. Ibidem, pg. 1167.

${ }^{138}$ CANOTILHO, J. J. G. Ibidem, pg. 72.

${ }^{139}$ MIRANDA, Jorge. Manual de Direito Constitucional, T. II, $4^{\text {a }}$ ed. Coimbra: Coimbra Editora, 2000, pg. 77.
} 
originária de livre regência da comunidade política mediante a instituição de um poder e a definição do seu estatuto jurídico. ${ }^{140}$

Assim, tem-se que o exercício material do poder constituinte corresponde à abertura de uma nova era constitucional, com o nascimento de uma constituição formal. Apesar disso, Miranda introduz um conceito de constituição material, ao reconhecer que só quando a ideia de Direito é democrática e a Constituição é aprovada pelo povo, diretamente ou por assembleia representativa, tem o órgão da Constituição formal uma autoridade que entronca, só por si, na própria legitimidade da Constituição material ${ }^{141}$.

Sua concepção não diverge substancialmente da tese exposta por Canotilho, que busca uma jurisdicização do poder constituinte, entendida como uma limitação material ao seu exercício. Nesses termos, explica Miranda:

\footnotetext{
Aliás, mesmo se a ideia de Direito é de democracia pluralista, o órgão encarregado de fazer a Constituição formal não goza de uma margem de liberdade plena; não adstrito, decerto, a um determinado e único sistema de direitos fundamentais, de organização econômica, de organização política ou de garantia de constitucionalidade, está sujeito a um limite - o da coerência com o princípio democrático e da sua preservação (não pode estabelecer uma Constituição não democrática) $)^{142}$.
}

O poder constituinte é, para o professor português, a manifestação necessária da ordem democrática, não sendo admitido como resultado válido de seu exercício o advento de uma ordem constitucional contrária ao reconhecimento da irrestrita participação popular.

Segundo Miranda, o exercício do poder constituinte se apresenta como o resultado lógico de uma ruptura ideológica com o direito vigente. Desse modo, tem-se que o fator determinante da abertura de cada era constitucional é, não a aprovação de uma Constituição formal (ou a redação de uma Constituição instrumental), mas sim o corte ou a contraposição frente à situação ou ao regime até então vigente ${ }^{143}$.

A constituição formal é, portanto, o resultado de um processo de mudança revolucionário, onde se constata o triunfo de certa ideia de Direito ou do nascimento de certo regime e o da formalização dessa ideia ou desse regime. Explica Miranda:

\footnotetext{
${ }^{140}$ MIRANDA, J. Ibidem, pg. 78.

${ }^{141}$ MIRANDA, J. Ibidem, pg. 73.

${ }^{142}$ MIRANDA, J. Ibidem, pg. 74.

${ }^{143}$ MIRANDA, Jorge. Poder Constituinte. In: Revista de Direito Público, n. 80, São Paulo, RT, out./dez., 1986, pg. 15.
} 
A revolução não é o triunfo da violência, é o triunfo de um Direito diferente ou de um diferente fundamento de validade do ordenamento jurídico positivo. Não é antijurídica; é apenas anticonstitucional por oposição à anterior Constituição, não em face da Constituição in fieri que, com ela, vai irromper. A quebra da ordem vigente só se torna possível pela presença de valores, princípios e critérios que, afastando os até então dominantes, vêm, do mesmo passo, carregar de legitimidade o ato revolucionário e desencadear efeitos normativos múltiplos, extensos e suscetíveis de, por seu turno, adquirirem uma dinâmica própria ${ }^{144}$.

Percebe-se que o texto de Miranda recebe uma forte influência do otimismo provocado pela redemocratização do seu país de origem, momento vivido nos sistemas políticos da América Latina tardiamente. Nesse sentido, assim como em autores como Bonavides, o exercício do poder constituinte é geralmente associado a experiências de libertação, de triunfo da democracia.

O autor chama a atenção para o fenômeno da transmutação, quando a Constituição formal passa por adaptações interpretativas decorrentes da transformação social. Aqui se constatam verdadeiras mudanças no princípio de legitimidade da constituição ${ }^{145}$, como esclarece Miranda, processo natural no desenvolvimento da democracia pós-totalitarismo. O autor português esclarece, ainda, não ser o conteúdo da constituição necessariamente democrático quando a fonte do poder constituinte assim se manifesta, inexistindo garantias de que a constituinte respeitará os anseios sociais que motivaram sua criação.

Um aspecto original da análise de Miranda reside na compreensão de que o poder constituinte não é, de todo, incondicionado, no sentido de que necessitará de regras de participação e organização prévias à criação da carta constitucional. Não se trata o poder constituinte de um fenômeno inteiramente alheio ao Direito, portanto:

E não pode, por exemplo, elaborar-se e aprovar-se uma Constituição através de assembleia constituinte ou de referendo sem uma legislação reguladora da capacidade eleitoral e do sufrágio e sem normas que estatuam como há-de surgir a vontade constituinte. Algo de semelhante se diga a respeito do ato constituinte bilateral. Mas até o ato constituinte unilateral monárquico carece ainda de regras; a outorga tem, pelo menos, de se fundar na autoridade real e de se transmitir pela forma específica dos atos do rei. ${ }^{146}$

A compreensão de Miranda mostra-se condizente com uma ideia de poder constituinte mais contemporânea, na medida em que não se espera, hoje, o surgimento de estados inteiramente novos, mas apenas a remodelação de sistemas políticos nacionais cuja

\footnotetext{
${ }^{144}$ MIRANDA, Jorge. Poder Constituinte. In: Revista de Direito Público, n. 80, São Paulo, RT, out./dez., 1986, pg. 18.

${ }^{145}$ MIRANDA, Jorge. Ibidem, pg. 20.

${ }^{146}$ MIRANDA, Jorge. Ibidem, pg. 25.
} 
legitimidade é objeto de questionamento. Nesse sentido, o poder constituinte não é um ato de fundação que parte do zero, mas uma adaptação, uma transformação de uma cultura jurídica já experimentada e exercida.

Esclarece Miranda:

Seja unilateral ou bilateral o ato constituinte, seja de base democrática ou autodemocrática, a formação de uma Constituição - e de uma Constituição definitiva, por maioria de razão - não pode fazer-se sem uma organização prévia e sem um enquadramento imposto pelo próprio princípio de legitimidade ${ }^{147}$.

A decisão sobre a criação de uma nova constituição, por mais sugestiva de uma ruptura que seja, não implica ignorar os procedimentos e as instituições constitutivas da ordem constitucional anterior. Muitas vezes a convocação da assembleia constituinte é obra de um poder legislativo eleito e em funcionamento, organizando-se os representantes constituintes a partir dos modelos normativos já experimentados pelo Estado. A convocação da assembleia constituinte representa, nesses casos, o anseio popular por uma transformação dos valores informadores da ordem jurídica - é mais uma ruptura ideológica do que propriamente institucional.

É por esse motivo que parece assistir razão a Miranda, ao chamar atenção para a experiência constituinte do século $\mathrm{XX}$, contrapondo-a à experiência revolucionária francesa no século XVIII. Enquanto que na França a necessidade de remodelação institucional era indispensável para o triunfo revolucionário da classe burguesa - tratava-se de substituir uma monarquia por uma república - no século $\mathrm{XX}$, e, em especial na segunda metade do século XX, têm-se estados cujo arcabouço de instituições já está consolidado, ainda que marcados pela instabilidade política da guerra e da crise econômica.

A análise de Miranda, Gonzalez, Lamounier e Nohlen pode ser especialmente esclarecedora. Segundo os autores, nos processos constituintes vividos por Espanha, Portugal e Brasil nas últimas décadas do século XX, tem-se a elaboração da constituição como um fenômeno singular no processo de transição de um regime autoritário para um regime democrático ${ }^{148}$.

\footnotetext{
${ }^{147}$ MIRANDA, Jorge. Ibidem, pg. 24.

${ }^{148}$ GONZALEZ E., Juan Jose; LAMOUNIER, Bolivar; MIRANDA, Jorge; NOHLEN, Dieter. El Proceso Constituyente: Experiencias a partir de cuatro casos recientes - España, Portugal, Brasil y Chile. In: Cadernos de Direito Constitucional e Ciência Política, São Paulo, Revista dos Tribunais, v. I, out./dez., 1992, pg. 39.
} 
$\mathrm{Na}$ Espanha, por exemplo, observou-se que a ruptura com a ordem constitucional foi provocada por fatores como: a exigência social por um marco político distinto, garantidor das liberdades públicas; a crise econômica pós-1973 e o fracasso do governo na reestruturação da economia espanhola; o estímulo do bloco europeu à integração, além das exigências de descentralização provenientes das regiões mais desenvolvidas como a Catalunha e o País Basco. Nesse caso, a constituinte não assumiu a função de uma completa remodelação institucional, mas buscou levar uma maior estabilidade social e econômica à sociedade espanhola ${ }^{149}$.

Os autores analisam igualmente o caso brasileiro, esclarecendo:

La Constituyente brasileña fue convocada en un quadro de relativa estabilidad político-institucional, en comparacíon con Portugal, pero fuertes tensiones económicas y sociales. En Brasil, el proceso de "descompresión" del régimen autoritario se prolongó por más de una década, de 1974 a 1985, combinando elementos de confrontación electoral-plebiscitaria y de acuerdo o negociación implícita entre la oposición y los militares ${ }^{150}$.

A função política do processo constituinte foi, nos casos históricos mencionados pelos autores, a busca por um novo fundamento de legitimidade, possível através do rompimento com a ordem jurídica anterior, e por um consenso entre as diversas forças políticas antagônicas ${ }^{151}$.

No Brasil, além do reforço de legitimidade, mostrava-se necessária, igualmente, a modernização institucional do país, a fim de que a sociedade pudesse enfrentar a grave situação econômica, marcada pela inflação descontrolada. No quadro de crise fiscal vivido pelo Estado brasileiro, a discussão esteve centrada mais em aspectos específicos da presença estatal na sociedade que em modelos ideológicos globais ${ }^{152}$. Os vinte e um anos de ditadura militar tiveram como resultado o enfraquecimento do sistema partidário, que necessitava se remodelar para as instituições democráticas ${ }^{153}$.

Parece insustentável, portanto, diante da análise histórica dos autores, que o poder constituinte tenha sido exercido, à luz das características da teoria clássica, como uma força inteiramente incondicionada, em especial no caso do Brasil. Isso porque, como esclarecem os autores, não se pode dizer que exigências de adaptação institucional tenham

\footnotetext{
${ }^{149}$ GONZALEZ E. et ali. Ibidem, pgs. 38-39.

${ }^{150}$ GONZALEZ E. et ali. Ibidem, pg. 39.

${ }^{151}$ GONZALEZ E. et ali. Ibidem, pg. 39.

${ }^{152}$ GONZALEZ E. et ali. Ibidem, pg. 42.

${ }^{153}$ GONZALEZ E. et ali. Ibidem, pg. 40.
} 
sido decisivas. O que ressalta, no caso brasileiro, é uma "sensação" de insuficiência de legitimidade, a qual seria suprida pela convocação da assembleia constituinte ${ }^{154}$.

É possível constatar que o poder constituinte pode ser exercido hoje, portanto, como um poder constituído, no sentido de que se autolimita através de normas de organização, necessárias em sociedades mais complexas. Miranda reconhece, ainda, a existência de limites materiais, condicionantes do resultado manifesto no texto constitucional. Segundo o autor, não decorre, porém, que o poder constituinte equivalha a poder soberano absoluto e que signifique capacidade de emprestar à Constituição todo e qualquer conteúdo, sem atender a quaisquer princípios, valores e condições ${ }^{155}$.

As limitações são de várias ordens: transcendentes, imanentes e heterônomas. As transcendentes provêm de imperativos de direito natural, de valores éticos superiores, enquanto as imanentes decorrem da identidade jurídica do Estado, aos costumes políticos do povo, a legitimidade jurídica em concreto. Por limites heterônomos têm-se as normas de direito internacional, provenientes de outras ordens jurídicas e que condicionam a elaboração da carta doméstica.

Canotilho, por sua vez, define o poder constituinte como a autoridade política que está em condições de, numa determinada situação concreta, criar, garantir ou eliminar uma Constituição entendida como lei fundamental da comunidade política ${ }^{156}$. O autor ressalta a identidade entre poder constituinte e força, aqui definida como autoridade.

O autor português reconhece que, com a União Europeia, a temática do poder constituinte ressurge no cenário político, a partir da indagação sobre a existência de um poder constituinte europeu capaz de criar uma ordem comunitária supranacional ${ }^{157}$. Questiona Canotilho:

Qualquer que seja a resposta, o problema está posto: é ou não política e juridicamente concebível um poder constituinte interdependente ou póssoberano assente no exercício em comum do poder constituinte originário dos povos? ${ }^{158}$

\footnotetext{
${ }^{154}$ GONZALEZ E. et ali. Ibidem, pg. 40.

155 MIRANDA, Jorge. Poder Constituinte. In: Revista de Direito Público, n. 80, São Paulo, RT, out./dez., 1986, pg. 27.

${ }^{156}$ CANOTILHO, J. J. Gomes. Direito Constitucional e Teoria da Constituição. Coimbra: Almedina, 2003 , pg. 65.

${ }^{157}$ CANOTILHO, J. J. G. Ibidem, pg. 67.

${ }^{158}$ CANOTILHO, J. J. G. Ibidem, pg. 68.
} 
Dentro da perspectiva do autor, a questão que se põe é, sobretudo, de legitimidade, de saber quem detém a autoridade constituinte.

Apesar de ressaltar a importância da revolução americana para definição do poder constituinte em seu sentido funcional, Canotilho reconhece ter sido a revolução francesa a experiência histórica que transportou dimensões completamente novas quanto ao tema, a partir da ideia de nação. Desse modo, no pensamento e prática da França revolucionária a imagem e representação do poder vigorosamente expressa pelo abade E. Sieyès é esta: o poder constituinte tem um titular - la Nation - e caracteriza-se por ser um poder originário, autónomo e omnipotente ${ }^{159}$.

O autor português ressalta que o poder constituinte é uma construção cultural: tratase de uma concepção decorrente de uma laboriosa construção teórica ${ }^{160}$. Analisando a distinção entre o poder constituinte originário e o derivado, Canotilho se refere ao paradoxo da democracia consistente na "domesticação" do poder constituinte de revisão, indispensável à estabilidade constitucional.

Nesse sentido, questiona o autor como pode uma constituição colocar-nos perante um dilema contramaioritário ao dificultar deliberadamente a "vontade das gerações futuras" na mudança das suas leis ${ }^{161}$ ? Tem-se, aqui, uma permanente "abertura do futuro" como possibilidade de transformação valorativa capaz de tornar a carta constitucional insuficiente para resolver os problemas sociais, gerando um gap entre a ordem jurídica e os anseios democráticos.

Desse modo, ao mesmo tempo em que a criação de uma constituição corresponde a um desejo de permanência e relativa imutabilidade normativa, é preciso reconhecer que nenhuma constituição pode conter a vida ou parar o vento com as mãos ${ }^{162}$. Tem-se como uma possibilidade potencial a revolução jurídica como alternativa à falta de plasticidade da constituição, decorrente da perda de sua força normativa. Desse modo, reconhece Canotilho: 
toda e qualquer manifestação do próprio poder constituinte. Em sentido absoluto, nunca a "geração" fundadora pode vincular eternamente as gerações futuras ${ }^{163}$.

Do ponto de vista teórico é preciso distinguir, portanto, o poder constituinte do poder de revisão, sendo aquele chamado em toda sua força quando este não mais for capaz de atualizar a ordem normativa constitucional. O poder de revisão, na medida em que está comprometido como a permanência da constituição positivada, deve conhecer limites, que o impedem de desfigurar o núcleo axiológico da carta produzida pelo poder constituinte originário.

\subsubsection{Doutrina Brasileira}

Ao analisar a sistematização construída pela doutrina constitucionalista brasileira observa-se uma notória influência dos publicistas franceses sobre os estudos nacionais. Tratando o tema de forma homogênea, sem grandes disparidades conceituais, os autores brasileiros associam a teoria do poder constituinte à contribuição de Sieyès, o que implica sua vinculação ao constitucionalismo liberal e ao advento do estado de direito organizado pelo sistema representantivo.

Em monografia publicada na década de 70 do século XX, Ferreira Filho analisa os principais aspectos do poder constituinte, desde sua definição até os problemas atinentes ao exercício do poder de reformar a constituição ${ }^{164}$. Segundo a sua definição, tem-se que:

\footnotetext{
$\mathrm{Na}$ verdade, a ideia da existência de um Poder Constituinte é o suporte lógico da ideia de Constituição; é a justificativa da superioridade da Constituição, que derivando do Poder Constituinte, não pode ser modificada pelos poderes constituídos, porque estes são obra daquele, por intermédio da própria Constituição. O titular desse Poder Constituinte, segundo Sieyès, é a nação. ${ }^{165}$
}

O fundamento de validade da constituição é, no raciocínio exposto pelo autor, a supremacia da vontade soberana que se põe coercitivamente através da positivação do texto constitucional.

\footnotetext{
${ }^{163}$ CANOTILHO, J. J. G. Op. cit.

164 FERREIRA FILHO, Manoel Gonçalves. Direito Constitucional Comparado: I - O Poder Constituinte. São Paulo: Editora da Universidade de São Paulo, 1974.

${ }^{165}$ FERREIRA FILHO, M.G. Ibidem, pg. 14.
} 
Ferreira Filho aponta uma relação entre poder constituinte e revolução, ao reconhecer que, enquanto fenômeno social, a revolução é o veículo do poder constituinte, o transportador, por assim dizer, o instrumento pelo qual se concretiza a manifestação do poder constituinte ${ }^{166}$. Isso porque o resultado necessário do processo revolucionário é a elaboração de uma nova constituição, com a formalização da vontade triunfante.

A relação não é, apesar disso, necessária e, de acordo com Ferreira Filho, não pode ser colocada em termos absolutos ${ }^{167}$, na medida em que são encontrados exemplos históricos de manifestação do poder constituinte sem a necessidade de deflagração de um processo revolucionário.

A existência de limites ao poder constituinte originário não é evidente dentro da perspectiva argumentativa do professor paulista. Isso porque, segundo leciona, $a$ Constituição, da qual parte a ordem jurídica, não é gerada pelo direito, ou melhor, não é gerada por um poder de direito. Seria o texto constitucional a manifestação de um fato, uma força social, e, enquanto fato, o exercício do poder constituinte se apresenta como pura potência. Desse modo, tem-se que para o positivismo jurídico, o poder constituinte é simplesmente uma força social, a ser estudada pela Sociologia, e não algo que deva ser estudado estritamente pelo Direito ${ }^{168}$.

Ao explicar as formas de manifestação do poder constituinte, Ferreira Filho esclarece que não há forma prefixada para a expressão do poder constituinte, o que permite defini-lo como poder incondicionado. É possível apresentar, todavia, modos usuais de seu exercício: a outorga e a convenção (ou assembleia constituinte) ${ }^{169}$.

Enquanto que a outorga se caracteriza pela unilateralidade da declaração que institui a carta constitucional, razão por que se associa a sua existência aos regimes autoritários, na medida em que a outorga só pode vir de cima, só pode vir de quem detém o poder. A convenção, em contrapartida, provém da deliberação da representação popular. Segundo Ferreira Filho, na Convenção é a representação convocada para tanto que estabelece, através do debate e das votações, uma Constituição ${ }^{170}$.

\footnotetext{
${ }^{166}$ FERREIRA FILHO, M.G. Ibidem, pg. 41.

${ }^{167}$ FERREIRA FILHO, M.G. Ibidem, pg. 40.

${ }^{168}$ FERREIRA FILHO, M. G. Ibidem, pg. 64.

${ }^{169}$ FERREIRA FILHO, M. G. Ibidem, pg. 74

${ }^{170}$ FERREIRA FILHO, M. G. Ibidem, pg. 80.
} 
A associação entre poder constituinte e revolução também é manifesta por Barrufini em sua obra Revolução e Poder Constituinte. Identificado como uma expressão da liberdade, o poder constituinte não se reparte, é insuscetível de alienação ou prescrição, estando fora do estado. Barrufini entende ser o exercício do poder constituinte a mais alta expressão da soberania, ainda que não apresente maiores considerações sobre o problema da legitimidade política ${ }^{171}$.

Em texto publicado antes da constituinte de 1987, no Brasil, e produzido décadas antes para o concurso de livre docência, Saldanha faz uma análise sobre o poder constituinte cujo ponto de vista se apresenta como "culturológico". Tentando unir o universalismo de uma proposta teórica abstrata com a observação da experiência histórica, o autor afirma ser o tema relativo ao poder constituinte tão árduo e complexo quanto fundamental e sugestivo, ainda que pouco tratado na bibliografia nacional ${ }^{172}$.

Para Saldanha, a constituição é considerada, sempre, a obra de um poder constituinte, que aparece justamente como fundamento do elemento de força que a Constituição implica ${ }^{173}$. O autor entende o poder constituinte como uma passagen, isto é, a transformação do poder ao direito, ocorrendo sempre que o poder, fato social primário, assume sentido jurídico ${ }^{174}$. Sendo a aptidão ou a oportunidade de estabelecer uma Constituição, o poder constituinte detém um sentido duplo, tanto é fato histórico, como uma "intenção axiológica", quando significa ser-para-constituir ${ }^{175}$.

O autor distingue o poder constituinte do poder do estado, já que este é uma modalidade de poder constituído, enquanto aquele é um poder preconstitucional, é a fonte do poder do estado, sendo este um poder constitucional. Para Saldanha, mesmo o poder constituinte originário tem marcas de um poder constituído, embora em menor dimensão. Isso porque nenhum poder constituinte originário pode atuar hoje com independência absoluta de uma experiência constitucional qualquer, como o terão sido as primeiras tentativas constitucionais na história do Ocidente ${ }^{176}$.

\footnotetext{
${ }^{171}$ BARRUFINI, José Carlos Toseti. Revolução e Poder Constituinte. São Paulo: RT, 1976, pg. 3.

${ }^{172}$ SALDANHA, Nelson. O Poder Constituinte. São Paulo: Revista dos Tribunais, 1986.

${ }^{173}$ SALDANHA, Nelson. Ibidem, pg. 57.

${ }^{174}$ SALDANHA, Nelson. Ibidem, pg. 65.

${ }^{175}$ SALDANHA, Nelson. Op. cit.

${ }^{176}$ SALDANHA, Nelson. Ibidem, pg. 84.
} 
Em análise sobre a mutabilidade da constituição, Baracho identifica o exercício do poder constituinte originário com a premente necessidade de atualização da ordem constitucional em face da evolução social:

A identidade originária da Constituição e as mudanças de significado que ocorrem durante a sua aplicabilidade, levam às formulações sobre se ela própria é uma Constituição Provisória, no que se refere à Teoria da Constituição Originária, tendo em vista a necessidade e a possibilidade de edição de nova Constituição a qualquer momento ou não. ${ }^{177}$

Trabalhando com os conceitos de permanência, mutabilidade e revisão, Baracho reconhece que somente diante da completa impossibilidade de modificação do texto constitucional pela interpretação é que se justifica a instituição de uma nova assembleia constituinte. Nessa perspectiva, tem-se o poder constituinte como um processo permanente e não temporariamente delimitado. A constituição não é feita em um momento determinado, realiza-se e efetiva-se constantemente. Isso porque a própria interpretação da constituição, que a atualiza e transforma, é, para o autor, uma manifestação do "poder constituinte em sentido amplo" ${ }^{, 178}$.

Nesse caso, justifica-se a permanência do texto constitucional - atualizado pelo intérprete e pela jurisprudência - pela legitimidade incorporada no momento de sua elaboração. Mantém-se, assim, a excepcionalidade histórica do exercício do poder constituinte, que deve ser compreendido como um ato de ruptura, de completa superação de uma ordem instituída anteriormente.

A partir do raciocínio do autor, tem-se que, mantendo-se a carta constitucional legítima, no sentido de sua aceitação pelo corpo social, injustificável, portanto, a convocação da assembleia constituinte, sendo mais razoável a atualização das normas constitucionais de forma indireta, através da atuação da doutrina, da interpretação judicial.

Bonavides, por sua vez, identifica Sieyès como o teorista por excelência do sistema representativo, sendo o francês o responsável por inserir o poder constituinte na moldura do referido sistema ${ }^{179}$. O constitucionalista esclarece, ao apresentar a teoria do poder constituinte ao leitor:

Deriva essa teoria, conforme já ponderamos, do movimento racionalista dos pensadores franceses, nomeadamente de Sieyès. Parte o publicista do

\footnotetext{
${ }^{177}$ BARACHO, José Alfredo de Oliveira. Teoria Geral da Revisão Constitucional e Teoria da Constituição Originária. In Revista da Faculdade de Direito da UFMG, Belo Horizonte, v. 34, 1994, pg. 49.

${ }^{178}$ BARACHO, J. A. O. Ibidem, pg. 62.

${ }^{179}$ BONAVIDES, Paulo. Curso de Direito Constitucional. São Paulo: Malheiros, 2004, pg. 145.
} 
"terceiro estado" de um conceito de Rousseau: o de soberania popular, que é na essência o poder constituinte do povo, fonte única de que procedem todos os poderes públicos. ${ }^{180}$

Segundo Bonavides, o conceito de poder constituinte é político. É o poder de fazer a constituição, não se prendendo a limites formais, sendo extrajurídico, portanto ${ }^{181}$. O exercício do poder constituinte é anterior ao próprio estado; uma potência revolucionária. Trata-se, assim, de um poder supra legem ou legibus solutus, um poder a que todos os poderes constituídos hão necessariamente de dobrar-se ao exercer ele a tarefa extrajurídica de criar a Constituição ${ }^{182}$.

O autor chama atenção para o aspecto funcional de poder constituinte - outro ponto que o aproxima da concepção teórica clássica: o poder constituinte tem a atribuição de fundar o estado, organizando o exercício do poder pela distribuição das competências, fazendo com que o Povo seja o efetivo sujeito da soberania ${ }^{183}$.

Silva, em suas considerações sobre o tema, estabelece o conceito de poder constituinte como o poder que cabe ao povo de dar-se uma constituição. Sua importância para o Estado é capital, na medida em que se apresenta como a mais alta expressão do poder político, a energia capaz de organizar política e juridicamente a Nação ${ }^{184}$. Nos textos de Silva sobre a matéria, produzidos por ocasião da redemocratização brasileira, observa-se a identificação do poder constituinte como poder redentor, necessário para a completa superação do regime militar no Brasil.

Viveu-se, na segunda metade da década de oitenta do século XX, no Brasil, o que Silva chamou de situação constituinte, situação que se caracteriza pela necessidade de criação de normas fundamentais, consagradoras de nova ideia de direito, informada pela justiça social $^{185}$. O momento de mudança representado pelo exercício do poder constituinte é visto com otimismo, como uma oportunidade de concretização da democracia plena no Brasil. Silva, assim como Bonavides, compreendem o poder constituinte como uma manifestação de um anseio democrático.

\footnotetext{
${ }^{180}$ BONAVIDES, Paulo. Ibidem, pg. 145.

${ }^{181}$ BONAVIDES, Paulo. Ibidem, pg. 146.

182 BONAVIDES, Paulo. Ibidem, pg. 149.

${ }^{183}$ BONAVIDES, Paulo. Ibidem, pg. 149.

${ }^{184}$ SILVA, José Afonso da. Poder Constituinte e Poder Popular: Estudos sobre a Constituição. São Paulo: Malheiros, 2007, pg. 67.

${ }^{185}$ SILVA, J. A. Ibidem, pg. 19.
} 
Mendes et ali apresentam um conceito voluntarista de poder constituinte, ao identificá-lo como a força política consciente de si que resolve disciplinar os fundamentos do modo de convivência na comunidade política. O poder constituinte é, para os autores, definido com a autoridade máxima da Constituição, uma magnitude que fundamenta a própria validade do texto constitucional ${ }^{186}$.

Reconhecendo a necessária relação entre o conceito de poder constituinte e os estudos de Sieyès - o que nos permite situar a visão dos autores dentro de uma teoria clássica - Mendes et ali definem o poder constituinte como a vontade política da nação, ainda não seja essa vontade independente de valores éticos, religiosos e culturais $^{187}$.

Os constitucionalistas mencionados caracterizam o poder constituinte como um poder inicial, ilimitado e incondicionado, que subsiste mesmo após a conclusão do texto constitucional e sua aprovação pela assembleia constituinte. Trata-se, assim, de um poder permanente, e, como também é incondicionado, não se sujeita a formas prefixadas para operar $^{188}$. Não se vislumbram, aqui, inovações ou diferenças conceituais significativas em relação aos demais autores referidos, indicando a uniformidade com que o tema é tratado na doutrina constitucionalista brasileira.

Horta, assim como Barrufini e Ferreira Filho, ressalta o caráter revolucionário do poder constituinte, trabalhando o seu conceito em termos extremamente semelhantes àqueles expostos por Sieyès:

A crise revolucionária deflagra a contradição entre o vigente direito estatal, que tem na Constituição o seu mais alto documento, cuja legitimidade é contestada, e a nova legitimidade que o poder constituinte originário vai conferir ao Direito estatal, a partir da nova Constituição. Portador de aspirações emergentes, o poder constituinte originário busca apoiar-se diretamente na Nação e na vontade popular. ${ }^{189}$

O autor estabelece uma nítida implicação entre a soberania popular e o exercício do poder constituinte, vinculando sua concepção teórica aos valores oriundos do movimento revolucionário francês, do qual Sieyès é um dos expoentes. Inspirado na referência do francês Carré de Malberg, Horta estabelece a supraestatalidade do poder constituinte,

\footnotetext{
${ }^{186}$ MENDES, Gilmar; COELHO, I. M.; BRANCO, P. G. G. Curso de Direito Constitucional. São Paulo: Saraiva, 2007, pg. 187.

${ }^{187}$ MENDES, G. et ali. Ibidem, pg. 189.

${ }^{188}$ MENDES, G. et ali. Ibidem, pg. 190.

${ }^{189}$ HORTA, Raul Machado. Direito Constitucional, $5^{\mathrm{a}}$ ed. Belo Horizonte: Del Rey, 2010, pg. 3.
} 
afirmar que a questão do poder constituinte se coloca nos termos da formação originária do Estado: é uma questão de fato e não de Direito ${ }^{190}$.

Barroso estabelece o desenvolvimento da teoria do poder constituinte a partir do advento do constitucionalismo moderno, em um ambiente dominado pelas aspirações de racionalidade do iluminismo, do jusnaturalismo e do contratualismo ${ }^{191}$. A nota voluntarista também esta presente no conceito apresentado pelo autor, já que, segundo esclarece, $o$ poder constituinte, como qualquer poder efetivo, envolve a manifestação da vontade de quem o exerce e o consentimento ou a sujeição de quem a ele se submete.

Para Barroso, trata-se do poder de elaborar e impor a vigência de uma Constituição. Situa-se ele na confluência entre o Direito e a Política, e sua legitimidade repousa na soberania popular ${ }^{192}$. Também o autor não inova ao reconhecer a incondicionalidade originária do poder constituinte e a titularidade popular do seu exercício.

Segundo a análise de Tavares, investigar a problemática do poder constituinte é debruçar-se sobre o intricado problema do fundamento de uma constituição, uma vez que se trata do supremo fornecedor das diretrizes normativas que constarão desse documento. $\mathrm{O}$ autor estabelece que, de acordo com a concepção clássica, poder constituinte originário corresponde ao poder de elaborar e colocar em vigência uma constituição ${ }^{193}$.

Segundo o constitucionalista, o poder constituinte não constitui propriamente um poder, razão pela qual prefere Tavares designá-lo como força ou energia constituinte, o que salienta o seu caráter de extrajurídico. Ao analisar a distinção entre poder constituinte originário e derivado, o autor deixa claro seu pensamento:

\footnotetext{
Mas faremos uma distinção que sem os afigura essencial, entre o que seria um poder pleno, verdadeira força, daquele que se realiza dentro de uma estrutura estatal (social, política e econômica) já existente, estrutura que em suas linhas gerais permanece, não obstante a mudança da Lei Magna. A distinção entre esses dois poderes de mudança da constituição é imperiosa: poder constituinte de um lado e competência de reforma constitucional de outro ${ }^{194}$.
}

\footnotetext{
${ }^{190}$ HORTA, Raul Machado. Ibidem, pg. 5.

${ }^{191}$ BARROSO, Luís Roberto. Curso de Direito Constitucional, 2a edição. São Paulo: Saraiva, 2010, pg. 96. 192 BARROSO, L. R. Ibidem, pg. 98.

${ }^{193}$ TAVARES, André Ramos. Reflexões sobre a Legitimidade e as Limitações do Poder Constituinte, da Assembleia Constituinte e da Competência Constitucional Reformadora. In: Cadernos de Direito Constitucional e Ciência Política, São Paulo, Revista dos Tribunais, n. 21, out./dez., 1997, pg. 221.

194 TAVARES, A, R. Ibidem, pg. 224.
} 
Citando o conceito de poder constituinte como função, estabelecido por Celso Ribeiro Bastos, Tavares esclarece que a força simbolizada pela assembleia constituinte nada mais é que uma forma excepcional e especial de produção jurídica. Tal "força" se caracteriza pela sua perenidade, pela latência própria da soberania, de modo que a conclusão e a promulgação ou outorga da constituição não constituem um esgotamento do poder constituinte. Trata-se, no dizer do autor, de uma força em forma de potência, mas pronta para agir em todo seu dinamismo quando assim impuserem as circunstâncias ${ }^{195}$.

Em trabalho sistematizador sobre a matéria, Wachowicz identifica o poder constituinte como uma força de auto-ordenação, consistindo no conteúdo essencial da soberania. Chamando atenção para a contextualização histórica do conceito, o autor reconhece que o surgimento da noção de poder constituinte é contemporânea à ideia de uma constituição escrita, sendo obra da Modernidade, portanto $^{196}$.

Em trabalho comparativo sobre a teoria clássica e a teoria sobre o poder constituinte hoje, Pedron apresenta uma releitura, definindo o poder constituinte a partir de marcos democráticos. Segundo o autor, as limitações ao poder constituinte originário, então, marcam uma nova compreensão acerca do tema: seu "exercício" não mais representa uma "ruptura integral com o edifício jurídico sustentado pela Constituição anterior "197. Aqui, é possível observar uma influência da visão de Miranda, exposta no tópico anterior, que compreende uma permanência, ou continuidade, entre as ordens jurídicas.

Desse modo, verifica-se que o constitucionalismo moderno marca-se como opositor da tese da originalidade do poder constituinte originário, afirmando sim uma continuidade "formal e material" entre o novo texto e o seu antecessor"198. Apesar de sua referência ao "constitucionalismo moderno", Pedron não menciona as referências que sustentam sua afirmação. Baseando seu argumento na tese sobre a recepção das normas infraconstitucionais pela nova carta constitucional, entende o autor que a continuidade da vigência da norma hierarquicamente inferior é uma evidência da continuidade do sistema normativo e do condicionamento do poder constituinte originário.

\footnotetext{
195 TAVARES, A. R. Ibidem, pg. 225.

${ }^{196}$ WACHOWICZ, Marcos. Poder Constituinte e Transição Constitucional. Curitiba: Juruá, 2000, pg. 28.

${ }^{197}$ PEDRON, Flávio Quinaud. A Teoria do Poder Constituinte Hoje: A Tese do Patriotismo Constitucional como das Antigas Tradições. In: Revista dos Tribunais, São Paulo, v. 98, n. 884, junho, 2009, pg. 32.

${ }^{198}$ PEDRON, F. Q., Ibidem, pg. 32.
} 


\subsubsection{O Poder Constituinte na Teoria Constitucional de Carl Schmitt}

A utilização dos aportes teóricos construídos por Carl Schmitt na doutrina constitucional brasileira e europeia tem sido farta, ainda que não se possa reconhecer que haja uma identidade de conteúdo e de conceitos entre a teoria clássica do direito público e a concepção schmittiana sobre o poder constituinte. Traz-se, aqui, uma breve leitura da análise do alemão sobre o tema, a fim de esclarecer eventuais imprecisões terminológicas.

Em sua obra $A$ Teoria da Constituição, Schmitt se propõe a estabelecer um sistema teórico para o direito constitucional, como ramo especial da Teoria do Direito Público ${ }^{199}$, voltado especificamente com o estado burguês de direito, manifesto na Constituição de Weimar.

Segundo Schmitt, um dos problemas principais da teoria do direito público de sua época era a confusão entre a constituição do estado burguês de direito e a constituição como um todo, tida como conceito abstrato. Conforme explica, a constituição burguesa é uma experiência histórica específica e suas características não podem ser transformadas no paradigma universal de Constituição, sob pena de se perderem fenômenos essenciais da vida constitucional ${ }^{200}$. A fim de esclarecer essa e outras questões, propõe Schmitt a sistematização composta em sua Teoria da Constituição, entendida como uma teoria particular do estado burguês.

A partir da perspectiva positiva de constituição, Schmitt a define como o ato de um poder constituinte. Nesse sentido, tem-se que a constituição define a forma e o modo da unidade política, cuja existência lhe é anterior. A constituição positiva não tem, assim, a função de "fundar" o estado, mas unicamente de materializar a determinação consciente sobre a melhor forma de organizar a unidade política. Por esse motivo tem-se sua mutabilidade, pois a "forma" pode ser substituída por outra tantas vezes se mostre necessário. Para Schmitt:

Podem-se introduzir fundamentalmente novas formas sem que o Estado, isto é, a unidade política do povo, desapareça. Apesar disso, sempre deve haver no ato constituinte um sujeito capaz de agir, agindo com a vontade de produzir uma constituição. Tal constituição é uma decisão consciente

${ }^{199}$ SCHMITT, Carl. Teoría de la Constitución. Madrid: Editorial Revista de Derecho Privado, 19??, pg. XIX.

${ }^{200}$ SCHMITT, Carl. Ibidem, pg. XXII. 
que a unidade política, através do titular do poder constituinte, adota por si mesma e se dá a si mesma. ${ }^{201}$

É possível perceber, portanto, que Schmitt utiliza o termo unidade politica, preferindo-o à nação, como correspondente à sociedade. É a unidade que decide se dar uma nova forma de organização, materializando-a na constituição, que é o resultado de uma vontade triunfante, portanto. Igualmente interessante perceber que, da leitura do texto de Schmitt, o titular do poder constituinte não é a unidade política, mas o sujeito que a representa, em seu nome.

O autor chama atenção para o fato de que a constituição, enquanto carta positivada, não tem valor em si mesma, não sendo válida por sua justiça normativa, mas por ser o resultado da vontade da unidade política. Isso porque o fundamento de toda normatividade reside na decisão política do titular do poder constituinte, isto é, do Povo na Democracia e do Monarca na Monarquia autêntica ${ }^{202}$. Tem-se, com Schmitt, um conceito decisionista de constituição, mudando-se a perspectiva universalista oriunda do movimento revolucionário francês.

Para Schmitt, não há diferença entre estado e constituição, uma vez que esta nasce naturalmente com o estado mesmo, sendo igual ao Estado concreto em sua unidade politica e ordenação social ${ }^{203}$. É por isso que se afirma não ter o estado constituição, mas ser a constituição, no sentido de decisão sobre a forma da unidade política.

Em análise sobre o poder constituinte, o autor alemão afirma ter surgido a constituição moderna com a revolução francesa em 1789, sendo a carta revolucionária caracterizada pela existência de elementos liberais e democráticos. A constituição moderna tem como pressuposto, na visão de Schmitt, a teoria do poder constituinte ${ }^{204}$. Esclarece Schmitt:

A Teoria do Estado da Revolução francesa passa a ser, assim, uma fonte capital, não só para a dogmática política do todo o tempo seguinte, mas também para a construção jurídica do caráter positivo da moderna teoria da Constituição. O poder constituinte pressupõe o povo como uma entidade política existencial; a palavra "nação" designa um povo capaz de atuar, desperto para consciência política ${ }^{205}$.

\footnotetext{
${ }^{201}$ SCHMITT, Carl. Ibidem, pg. 25.

${ }^{202}$ SCHMITT, Carl. Ibidem, pg. 27.

${ }^{203}$ SCHMITT, Carl. Ibidem, pg. 50.

${ }^{204}$ SCHMITT, Carl. Ibidem, pg. 57.

${ }^{205}$ SCHMITT, Carl. Op. cit.
} 
O poder constituinte tem seu surgimento historicamente situado, no sentido que se emprega na teoria da constituição burguesa, sendo obra da revolução. Nesse caso, o fenômeno da revolução foi tão eficaz e ativo porque a decisão política fundamental consistiu em se fazer consciente da sua condição de sujeito capaz de atuar e fixar com autonomia o seu destino político ${ }^{206}$.

Em citação direta, Schmitt define o poder constituinte como:

A vontade política cuja força ou autoridade é capaz de adotar a concreta decisão de conjunto sobre modo e forma da própria existência política, determinando assim a existência da unidade política como um todo. Das decisões desta vontade se deriva a validade de toda posterior regulação legal-constitucional. As decisões, como tais, são qualitativamente distintas das normas legal-constitucionais estabelecidas sob seu fundamento $^{207}$.

Percebe-se a distinção entre constituição e lei constitucional, sendo entendida como uma diferença entre o conteúdo da decisão fundamental e sua expressão textual positivada. Enquanto a constituição é identificada como a decisão fundamental sobre as estruturas do Estado, a lei constitucional é condicionada, hierarquicamente inferior, tendo uma função instrumental. Assim, tem-se que as leis constitucionais têm seu fundamento de validade na Constituição, sendo-lhe "qualitativamente" distintas.

Toda lei, como regulação normativa, e também a lei constitucional, necessita para sua validade de uma decisão política prévia, adotada por um poder ou autoridade politicamente existente $^{208}$. A função da lei constitucional é operacionalizar a vontade constituinte, torná-la aplicável e, uma vez que não se confunde com a decisão política primordial, pode ser objeto de mudanças sem que se tenha verificado a mudança de constituição.

A ideia de continuidade do poder constituinte também está presente na teoria de Schmitt, no sentido de que a vontade subsiste mesmo após a criação da lei constitucional, isso porque todo conflito constitucional que afete as bases da decisão política do conjunto só pode ser decidido mediante a vontade do poder constituinte mesmo ${ }^{209}$. Sua função é,

\footnotetext{
${ }^{206}$ SCHMITT, Carl. Op. cit.

${ }^{207}$ SCHMITT, Carl. Ibidem, pg. 86.

${ }^{208}$ SCHMITT, Carl. Ibidem, pg. 25.

${ }^{209}$ SCHMITT, Carl. Ibidem, pg. 88.
} 
também, de controle e de preservação. Para Schmitt, o poder constituinte é unitário e indivisível, sendo o poder que abarca todos os outros poderes e "divisões de poderes" 210 .

O poder constituinte é, então, a força que provoca a própria existência do Estado, ao estabelecer sua forma. Uma decisão que triunfa, uma decisão que, alheia a qualquer tipo de condicionamento material, não é boa em si mesma, não tendo conteúdo "certo" ou "errado". É, no sentido político, uma força que se impõe sobre as demais forças sociais, subjugando-as. A Constituição é, para Schmitt, portanto, a manifestação dessa força, um ato de vontade. Como esclarece Goyard-Fabre, Schmitt insiste no caráter realista que uma Constituição exige para ser viável: de fato, é unicamente na existência concreta da nação, estima ele, que ela funda sua legitimidade ${ }^{211}$.

A função de "guardar" a Constituição é atribuída por Schmitt a um poder neutro e intermediário, um "terceiro" entre o legislativo e o judiciário, identificado na figura do presidente do reich. Para Schmitt, não há uma relação hierárquica entre o poder neutro e os demais poderes, sendo a relação entre eles de coordenação e não de subordinação ${ }^{212}$. Sua existência é justificada na necessidade de criação de um "sobrepeso" aos demais poderes, evitando que um deles se converta em verdadeiro senhor da Constituição.

Para Schmitt,

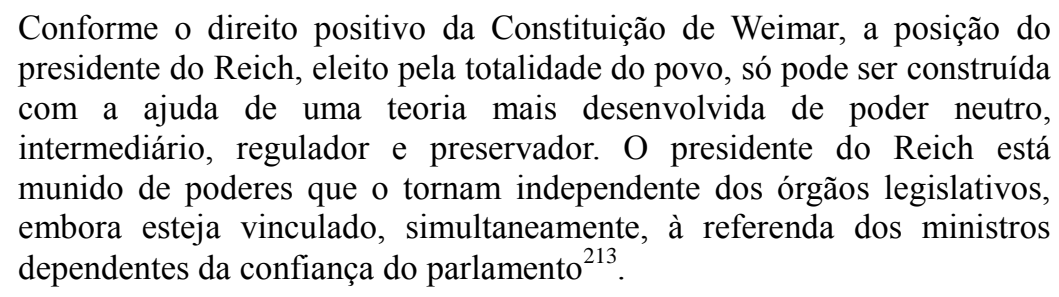

De acordo com sua proposta teórica, o chefe do Executivo assume uma função de equilíbrio entre os poderes, não lhes estando subordinado, na medida em que é independente até mesmo dos órgãos legislativos e suas elaborações.

Mostra-se discutível a noção de "poder neutro" manifesta por Schmitt, uma vez que não se pode separar a "guarda" da Constituição de sua interpretação e de sua efetivação, conferindo ao presidente do reich um papel ativo de tomada de decisão em relação ao

\footnotetext{
${ }^{210}$ SCHMITT, Carl. Op. cit.

${ }^{211}$ GOYARD-FABRE, Simone. Princípios Filosóficos do Direito Político Moderno. São Paulo: Martins Fontes, 1999, pg. 266.

${ }^{212}$ SCHMITT, Carl. O Guardião da Constituição, tradução de Geraldo de Carvalho. Belo Horizonte: Del Rey, 2007, pg. 193.

${ }^{213}$ SCHMITT, Carl. Ibidem, pg. 201.
} 
destino do próprio Estado. A ausência de subordinação, a independência do guardião acabou por provocar a hipertrofia de um poder pretensamente neutro, culminando, na Alemanha, em uma forma de nacionalismo totalitário, em que o presidente do reich se sobrepôs face aos outros poderes instituídos, anulando-os do ponto de vista prático.

A concepção decisionista de Schmitt é distinta da proposta clássica apresentada pela teoria do direito público francês, uma vez que o autor alemão não estabelece uma relação necessária entre o exercício do poder constituinte e o triunfo de uma determinada visão de sociedade. No sentido atribuído por Schmitt, o poder constituinte não está limitado por valores, sua função não é constitucionalizar o modelo liberal de sociedade, mas unicamente fundar o Estado conforme a vontade triunfante.

Enquanto que a teoria de Sieyès está fundamentada em uma proposta ideológica e revolucionária bastante clara - isto é, o poder constituinte é um poder de libertação da burguesia, simbolizada pelo advento da constituição liberal - em Schmitt não se encontrarão conteúdos pré-fixados por uma razão universalista. Schmitt chega a criticar o positivismo kelseniano, que declara o império do Direito sobre a política, domesticando-a:

\begin{abstract}
Tendo, quanto a ele, declarado encontrar seu próprio modelo no pensamento de Sieyès quando confere o poder constituinte à soberania nacional, e considerando que "é soberano aquele que decide mesmo em situações excepcionais", ele salienta que em caso algum poderia haver imperialismo do direito e que o "pan-normativismo jurídico kelseniano" é uma passagem de limite que, em razão da autoprodução de suas normas, está politicamente em falso ${ }^{214}$.
\end{abstract}

Sendo soberana, a decisão triunfante manifesta pelo poder constituinte não está adstrita a qualquer norma jurídica ou mesmo moral ${ }^{215}$. É por essa razão que reconhece Schmitt a possibilidade de que o sujeito do poder constituinte seja a organização de uma minoria, quando, então, o Estado assume a forma de uma aristocracia ou oligarquia. Desse modo, pode ser que uma organização adote uma decisão fundamental sem invocar a vontade da maioria dos cidadãos, as decisões políticas fundamentais sobre modo e forma da existência política, isto é, de uma Constituição ${ }^{216}$.

\footnotetext{
${ }^{214}$ GOYARD-FABRE, Simone. Ibidem, pg. 267.

${ }^{215}$ Goyard-Fabre chega a afirmar, em análise do pensamento de Schmitt, que $o$ Estado não pode portanto reduzir-se, nem em seu aspecto organizacional nem em sua vocação funcional, a um corpo de regras e de leis construído apenas pela razão segundo uma lógica pura. (Cf. GOYARD-FABRE, Simone. Ibidem, pg. 267.)

${ }^{216}$ SCHMITT, Carl. Ibidem, pg. 93.
} 
Trata-se, aqui, da aceitação do fenômeno social da dominação como válido do ponto de vista constitucional, o que seria impensável dentro da proposta revolucionária francesa. Em verdade, não reconhecia Schmitt a existência de direitos fundamentais como conteúdo necessário da constituição; sua aposição no texto de Weimar representava apenas uma vitória tática obtida por uma coalizão de partidos em um momento favorável, cujo objetivo é preservar seus interesses particulares contra as variáveis maiorias parlamentares $^{217}$. Esclarece Bercovici:

Em sua Teoria da Constituição, de 1928, ele afirmaria que a Constituição
de Weimar era uma Constituição por conter decisões políticas
fundamentais sobre a forma de existência política concreta do povo
alemão. No entanto, ela também possuía em seu texto inúmeros
compromissos e obscuridades que não representavam decisão alguma,
mas, pelo contrário, cuja decisão havia sido adiada. Schmitt também se
preocupou em estabelecer a relação dos direitos fundamentais com a parte
organizacional da Constituição, embora considerasse a segunda parte da
Constituição de Weimar uma proclamação política programática e
incoerente, realçada com a contradição intrínseca que existiria entre a
previsão dos direitos individuais e dos direitos sociais no mesmo texto
constitucional ${ }^{218}$.

Na medida em que não consistiam decisões, não seriam os direitos fundamentais parte da constituição, mas simples compromissos políticos. Trata-se de uma distinção considerável entre a proposta teórica apresentada por Schmitt e o modelo clássico da doutrina francesa, que estabelece uma relação indissociável entre constituição, separação de poderes e direitos individuais, razão pela qual se mostra incoerente a utilização simultânea dos dois aportes teóricos para fundamentação e classificação do poder constituinte hoje, como pretendem alguns doutrinadores.

A crítica ao decisionismo da teoria schmittiana será desenvolvida em capítulo posterior, no qual se buscará estabelecer uma teoria propositiva e democrática de poder constituinte. Será analisada a sustentabilidade racional de uma tal concepção teórica, inclusive quanto à função desempenhada pelo poder executivo no equilíbrio de forças estatais.

${ }^{217}$ BERCOVICI, Gilberto. Constituição e Estado de Exceção Permanente: Atualidade de Weimar. Rio de Janeiro: Azougue Editorial, 2004, pg. 31.

${ }^{218}$ BERCOVICI, Gilberto. Ibidem, pg. 30. 


\subsection{Da Natureza do Poder Constituinte}

A natureza do poder constituinte é objeto de divergências teóricas consideráveis, seja para considerá-lo um poder de fato e, enquanto tal, alheio a qualquer tipo de limitação jurídica, seja para definir o poder constituinte como poder de direito, prévio, original, fundador. Apresenta-se a revisão bibliográfica das teses sobre a natureza do poder constituinte, com base na sistematização teórica apresentada pelo francês Georges Burdeau, fundada num dualismo jurídico em que o direito positivado é subordinado a um direito superior.

A constituição é, para Burdeau, um produto cultural do exercício do poder titularizado pelo soberano, que não conhece qualquer espécie de limitação ${ }^{219}$. Segundo o francês, o poder constituinte possui uma natureza híbrida, na medida em que se encontra no ponto de intersecção entre direito e politica ${ }^{220}$. O seu exercício é, assim, insuscetível de condicionamento por um sistema de normas hierarquizado, na medida em que representa um rompimento forçado com a ordem normativa anterior. Diferenciando-o dos poderes constituídos, o autor francês o define como uma potência extra-estatal, caracterizando-a como um poder inicial, autônomo e incondicionado.

Burdeau salienta que se mostra paradoxal refutar a qualidade jurídica de um poder por meio do qual a ideia de direito se faz reconhecer e, por consequência, se impõe ao ordenamento como um todo ${ }^{221}$. Embora nele não se possa reconhecer as limitações formais e materiais próprias do exercício dos poderes constituídos, o poder constituinte, de acordo com a argumentação desenvolvida pelo constitucionalista francês, na medida em que funda o direito positivo, apresenta inegável natureza jurídica, híbrida, própria, decorrente da necessária subordinação do direito positivo a um direito suprapositivo. Para Burdeau:

A tese de que compartilhamos é baseada numa concepção dualista de direito. Há, de uma parte, a regulamentação positiva, resultado da atividade jurídica do Poder, e, de outra parte, seja uma manifestação da razão, seja o resultado da natureza das coisas ou um fato social, uma regra superior a todo o Poder instituído, não limitado por ele e cujo cumprimento se faz obrigatório. Entre as duas categorias de normas, não há nem uma origem comum, nem natureza comum, tão somente uma

\footnotetext{
${ }^{219}$ BURDEAU, Georges. Ibidem, pg. 174.

${ }^{220}$ BURDEAU, Georges. Ibidem, pg. 171.

221 Tradução livre de "Il semble paradoxal de refuser la qualité juridique à un pouvoir par lequel l'idée de droit se fait reconnaître et, par suite, s'impose dans l'ordonnancement juridique tout entier".
} 
relação hierárquica segundo a qual o direito positivo não poderá ser que uma expressão, mais ou menos defeituosa, da norma superior ${ }^{222}$.

Embora manifeste sua concepção dualista de forma clara, Burdeau não esclarece quais seriam tais limites, reportando-se tanto ao jusnaturalismo racionalista como ao puro fato social. Nesse ponto, apresenta-se uma contradição na concepção teórica do autor, pois, ao mesmo tempo em que sustenta a juridicidade do poder constituinte, recusando a tese da completa ilimitação original, apresenta como limite o fato, isto é, a normatização provocada pela própria organização social, independentemente do direito.

Bonavides segue a linha de Burdeau, apresentando uma tese semelhante, ao subordinar o poder constituinte a elementos suprapositivos, estabelecendo a existência de duas constituições, a formal e a real. Bonavides enfatiza o aspecto político e filosófico do poder constituinte, estritamente associado à questão da legitimidade do exercício ${ }^{223}$. Segundo o autor:

A constituição real, condicionante da constituição formal, não se faz unicamente de elementos materiais senão que abrange também as correntes espirituais portadoras de valores básicos, cuja presença marca a identidade nacional e a vocação do poder ${ }^{224}$.

Uma vez que deve ser exercido pelo seu titular legítimo, o poder constituinte, ainda que supra legem, deve ser o reflexo do anseio de normatização do soberano, materializando nas normas a vontade popular. O autor ressalta o caráter híbrido da natureza desse poder, que ora surge como categoria fática que independe de valores, ora como categoria valorizada que exprime uma determinada forma de legitimidade ${ }^{225}$.

Na mesma linha de raciocínio, reconhece Canotilho que, nos termos da teoria clássica, o poder constituinte se define como um poder ilimitado, autônomo e livre, estando, assim, juridicamente desvinculado. Para o autor português, a doutrina atual

\footnotetext{
${ }^{222}$ BURDEAU, Georges. Ibidem, pg. 551. Tradução livre: "La thèse que nous envisageons repose sur une conception dualiste de la notion de droit. Il y aurait, d'une part, la réglementation positive, résultat de l'activité juridique du Pouvoir, et, d'autre part, soit perçue par la raison, soit résultant de la nature des choses ou du fait social, une règle supérieure à tout Pouvoir établi, n'aatendant rien de lui et s'imposant, au contraire, à son observation. Entre ces deux catégories de règles il n'existerait ni communauté d'origine, ni identité de nature, mais seulement um rappot hiérarchique selon lequel le doit positif ne pourrait être qu'une expression, toujours plus ou moins défectueuse, de la norme supérieure".

${ }^{223}$ É nesse sentido que Bonavides afirma que a teoria do poder constituinte é basicamente uma teoria da legitimidade do poder. BONAVIDES, Paulo. Curso de Direito Constitucional, $14^{a}$ edição. São Paulo: Malheiros, 2004, pg. 141.

${ }^{224}$ BONAVIDES, Paulo. Teoria do Estado, $4^{a}$ edição. São Paulo: Malheiros, 2003, pg. 271.

${ }^{225}$ BONAVIDES, Paulo. Curso de Direito Constitucional, 14a edição. São Paulo: Malheiros, 2004, pg. 149.
} 
rejeita esta compreensão, verificando-se uma jurisdicização do poder constituinte, onde fica manifesto o seu carácter evolutivo ${ }^{226}$. Segundo Canotilho:

Por outro lado, este criador, este sujeito constituinte, este povo ou nação, é estruturado e obedece a padrões e modelo de conduta espirituais, culturais, éticos e sociais radicados na consciência jurídica geral da comunidade e, nesta medida, considerados como "vontade do povo". Além disto, as experiências humanas vão revelando a indispensabilidade de observância de certos princípios de justiça que, independentemente da sua configuração (como princípios suprapositivos ou como princípios supralegais para intra-jurídicos) são compreendidos como limites da liberdade e da omnipotência do poder constituinte. ${ }^{227}$

Tem-se, mais uma vez, a refutação da tese liberal da incondicionalidade original, o que se apresenta como uma consequência da observação dos fatos políticos do século XX. A ascensão dos regimes totalitários, o genocídio judeu e as restrições às liberdades individuais provocadas pelos regimes socialistas e pelas ditaturas militares nos países subdesenvolvidos apresentam-se como provas históricas de que um poder reconhecido como ilimitado, incondicional, autônomo pode resultar no retrocesso cultural e jurídico, ocasionando a desconstrução, pela força bruta, de espaços de liberdade e decisão antes conquistados pelo grupo social.

Febres-Cordero destaca a natureza jurídica do poder constituinte, assim como da revolução, como instrumento de transformação e criação do Direito. Diz o autor:

Dizer que o poder constituinte originário é jurídico significa afirmar que
participa da elaboração do Direito. O poder que uma revolução triunfante
inscreve na história é um poder de fato no sentido de que nenhuma
investidura legal precedeu sua ação. Mas não é, por isso, uma força
material, simples e sem alcances. Seu caráter essencial está naquilo que
constitui a vontade constituinte. Constituir o Estado, isto é, estabelecer os
fundamentos da ordem jurídica nova, explica sua razão de ser. E é por
força dessa tarefa que se traduz sua subordinação à ideia do Direito ${ }^{228}$.

A dogmática do poder constituinte não pode estar isenta, portanto, da análise da legitimidade do seu exercício, que é, rigorosamente, uma análise sobre a legitimidade do exercício do poder como um todo.

Carré de Malberg, em sentido contrário, identifica o exercício do poder constituinte como matéria de puro fato. Segundo o autor francês, constitui um erro crer que seja possível dar uma construção jurídica aos acontecimentos ou atos que determinaram a

${ }^{226}$ CANOTILHO, J. J. G. Direito Constitucional e Teoria da Constituição, $7^{\text {a }}$ ed. Coimbra: Almedina, 2003, pg. 81.

${ }^{227}$ CANOTILHO, J.J.G. Ibidem, pg. 81.

228 FEBRES-CORDERO, Jaime Buenahora. Filosofia e Historia del Poder Constituyente, in: UNIVERSITAS, N. 80, 1986, pg. 29. 
fundação do Estado e sua primeira organização ${ }^{229}$. A partir do raciocínio lógico de Malberg, o direito se impõe como uma decorrência do poder estatal, sendo compreendido como um conjunto das regras impostas aos homens em um território determinado, por uma autoridade superior, capaz de mandar com poder efetivo de dominação e de coação irresistivel $^{230}$.

Sendo a constituição a gênese jurídica do estado, segundo Malberg, o exercício do poder criador da própria constituição escapa do âmbito da juridicidade, sendo fato social. $A$ formação do Estado, diz Malberg, não está adstrita a nenhuma ordem jurídica préexistente; é a condição do direito e não está condicionada pelo direito ${ }^{231}$. O autor francês filia-se, portanto, à vertente positivista sobre a compreensão do poder constituinte, ao encará-lo como força social ilimitada capaz de impor o direito.

Ferreira Filho, em análise sobre a natureza do poder constituinte, apresenta duas teses, a positivista e a jusnaturalista. De acordo com a tese positivista, tem-se que a Constituição é um fato, e o poder constituinte é simplesmente uma força social, inexistindo, portanto, qualquer critério material que oriente ou limite o ato constituinte. Isso porque o estabelecimento de uma Constituição é, para o positivismo jurídico, um mero fato, um fato que está fora da órbita da ciência jurídica, ainda que lhe seja o ponto de partida $^{232}$. Segundo Ferreira Filho, dentro da perspectiva positivista, não cabe qualquer discussão sobre a limitação do poder constituinte, ainda que se possa conceber uma limitação moral, a título de problema meta-jurídico:

Dentro de uma perspectiva positivista, o poder constituinte é
juridicamente ilimitado, por uma razão óbvia, porque, para a doutrina
positivista, não há direito antes da manifestação do poder constituinte,
portanto, não há direito que possa ser invocado contra o poder
constituinte. Logicamente, ele é, juridicamente, ilimitado, o que não
significa que o poder constituinte não seja moralmente ilimitado. ${ }^{233}$

Citando Kelsen e sua norma hipotética fundamental, Ferreira Filho apresenta a tese segundo a qual a constituição é um pressuposto lógico transcendental sem o qual não se pode conceber a hierarquização do sistema normativo, razão pela qual ela é introduzida na

\footnotetext{
${ }^{229}$ MALBERG, Carré de. Teoría General del Estado. México: Faculdad de Derecho/UNAM, 2000, pg. 1.167.

${ }^{230}$ MALBERG, Carré de. Ibidem, pg. 1.167.

${ }^{231}$ MALBERG, Carré de. Ibidem, pg. 1.168.

232 FERREIRA FILHO, Manoel Gonçalves. Direito Constitucional Comparado: I - O Poder Constituinte. São Paulo: Editora da Universidade de São Paulo, 1974, pg. 64.

${ }^{233}$ FERREIRA FILHO, M.G. Ibidem, pg. 92.
} 
teoria kelseniana como a norma imediatamente inferior à norma hipotética que é o fundamento último do ordenamento ${ }^{234}$.

Para o positivismo, portanto, o fundamento material e os condicionantes fáticos para o exercício do poder constituinte - que é compreendido como o momento de criação do ordenamento jurídico - são alheios ao direito, no sentido de que lhes são anteriores. Nesse sentido, trata-se de um poder político e não jurídico.

A tese jusnaturalista, em contrapartida, reconhece que o direito não se resume ao direito positivo, razão pela qual o poder constituinte é um poder de direito. Nesse sentido, a temática do poder constituinte é diretamente ligada à problemática da liberdade, entendida como poder de autodeterminação individual ${ }^{235}$.

Assim, conforme a análise de Ferreira Filho:

Para o jusnaturalismo, o poder constituinte não é uma mera força social; é
um poder jurídico; é um poder de direito; é um poder que decorre, para a
comunidade - o conjunto de homens - da ordem jurídica natural. O poder
de auto-organização de uma sociedade, assim, não é um poder de fato, um
mero fato social.

Sendo o poder constituinte uma potência permanente, que não desaparece uma vez estabelecida uma Constituição, tem-se a possibilidade de transformação da ordem jurídica sempre que houver um descompasso entre o direito positivado e o fundamento suprapositivo, o direito natural.

Expondo a tese de Paul Bastid, Ferreira Filho elenca os limites de fato e de direito existentes na concepção jusnaturalista. Os limites de fato estão associados à eficácia do texto constitucional: uma constituição elaborada em desacordo com a ideia geral de justiça está fatalmente fadada ao insucesso. Uma Constituição não pode chocar-se frontalmente com as concepções mais arraigadas - a cosmovisão - da comunidade, porque, do contrário, não obterá a adesão dessa comunidade para as novas instituições ${ }^{237}$.

Os limites de iure, na visão de Bastid, que prefere não se vincular à ideia abstrata de um direito natural, são encontrados no direito internacional, em especial nas normas que tutelam os direitos fundamentais. Ferreira Filho expõe as dificuldades desta tese, ao reconhecer que, segundo a concepção que ainda prevalece, o direito internacional não é

\footnotetext{
${ }^{234}$ FERREIRA FILHO, M.G. Ibidem, pg. 66.

${ }^{235}$ FERREIRA FILHO, M.G. Ibidem, pg. 67.

${ }^{236}$ FERREIRA FILHO, M.G. Ibidem, pg. 68.

${ }^{237}$ FERREIRA FILHO, M.G. Ibidem, pg. 93.
} 
superior ao direito interna, isto é, o direito internacional não subordina o poder constituinte às suas normas ${ }^{238}$.

As dificuldades da tese positivista e da tese jusnaturalistas são bastante claras e não escapam a um maior exame crítico. Se não se pode conceber que o poder criador do Direito seja alheio ao Direito, um poder de fato que tudo pode, como força bruta (tese positivista), também não é razoável a tese que remete as limitações ao exercício do poder constituinte a uma ideia de Direito abstrata, impassível de objetivação e controle intersubjetivo (tese jusnaturalista). Isso porque, mesmo entre os teóricos do Direito Natural nos moldes clássicos, existem divergências teóricas consideráveis sobre quais direitos podem ser considerados apriorísticos, suprapositivos.

As contribuições teóricas de Hobbes e Locke, por exemplo, só para citar o caso do jusnaturalismo inglês, serviram de substrato ideológico tanto para a permanência da monarquia absoluta, com Hobbes, como para o reconhecimento da necessidade de limitação do poder político em face da autonomia individual, entendida como liberdade de propriedade, em Locke.

Saldanha, por sua vez, entende que só o direito pode definir o poder constituinte. Assim, no regime constitucional, o direito coloca antes de si um poder que o vai basear, ou por outra: que o direito se estabelece a si mesmo através de um poder. É o poder constituinte, na visão do constitucionalista brasileiro, uma manifestação do próprio direito, de modo que sua natureza não pode ser a de puro fato ${ }^{239}$.

O autor considera que o poder de criar a constituição, ainda que se apresente como poder pré-jurídico, representa um poder atraído por um fim, orientado por um objetivo, $e$ como tal controlado, domesticado, limitado. Não fora limitado e não seria jurídico; se o fosse de todo, não seria bem um poder sociologicamente distinto, nem constituinte ${ }^{240}$. Extrai-se da leitura de seu texto que a natureza do poder constituinte é híbrida, ostentando tanto uma feição jurídica como sociológica.

Inexistem, portanto, entre os teóricos que defendem a natureza jurídica - ainda que suprapositiva - do poder constituinte, postulados claros e objetivos que indiquem os

\footnotetext{
${ }^{238}$ FERREIRA FILHO, M.G. Ibidem, pg. 94.

${ }^{239}$ SALDANHA, Nelson. O Poder Constituinte. São Paulo: Revista dos Tribunais, 1986, pg. 66.

${ }^{240}$ SALDANHA, Nelson. Ibidem, pg. 90.
} 
limites ao exercício do poder, que são muitas vezes remetidos a noções abstratas de justiça, dignidade, direitos humanos, etc.

Para Tavares:

Quando tratamos dos atributos ou elementos caracterizadores do poder constituinte, inevitavelmente surge a seguinte polêmica: na linha juspositivista kelseniana, simplesmente elide-se todo o problema ao considerar metajurídica a noção do constituinte em sua fase de atuação. E é nesse diapasão que para Luis Recaséns Siches o poder constituinte como tal não poder ser compreendido através de razões jurídico-positivas, só históricas, políticas etc ${ }^{241}$.

É preciso reconhecer, portanto, que a simples negação da natureza jurídica do poder constituinte originário não tem como resultado racionalmente aceitável a tese da ilimitação material, uma vez que, como Tavares salienta, inexiste uma separação clara entre jurídico e político e também a origem da constituição, que é a origem última do sistema jurídico, deve ser estudada pela ciência jurídica ${ }^{242}$.

\subsection{Classificação do Poder Constituinte}

O poder constituinte é tradicionalmente subdividido pela doutrina constitucionalista em duas subcategorias: poder constituinte originário e poder constituinte derivado. Conforme preceitua Gözler, essa distinção só é desenvolvida com mais rigor no século XX, após a colaboração de Carré de Malberg e os estudos de Roger Bonnard. Somente após a sistematização empreendida pelos autores francesas é que se observa uma difusão da terminologia empreenda usualmente na literatura do direito constitucional, que "subdivide" o poder constituinte em poder originário e poder derivado ${ }^{243}$.

Originário é o poder de elaborar a constituição, no momento de ruptura com a ordem jurídica anterior. É, de acordo com a concepção teórica dominante, o ato político marcado pela incondicionalidade, no sentido de seu procedimento, e pela ilimitação

\footnotetext{
${ }^{241}$ TAVARES, André Ramos. Reflexões sobre a Legitimidade e as Limitações do Poder Constituinte, da Assembleia Constituinte e da Competência Constitucional Reformadora. In: Cadernos de Direito Constitucional e Ciência Política, São Paulo, Revista dos Tribunais, n. 21, out./dez., 1997, pg. 226. ${ }^{242}$ TAVARES, A. R. Ibidem, pg. 227.

${ }^{243}$ GÖZLER, Kemal. Pouvoir constituant. Bursa: Editions Ekin Kibatevi, 1999, pg. 10.
} 
material, no que tange aos conteúdos normativos que pode contemplar. Trata-se do poder constituinte propriamente dito.

O poder constituinte derivado é identificado como o poder de revisão, responsável pela atualização da ordem constitucional através de mudanças formais provocadas pelo processo legislativo, por meio de emendas. Sendo um poder instituído, é hierarquicamente inferior ao poder constituinte originário, estando subordinado tanto formalmente, pelo procedimento de revisão, como materialmente, quando a constituição é marcada pela existência de um núcleo duro, cláusulas pétreas, isto é, normas insuscetíveis de alteração pelo poder derivado, entre elas as próprias regras que disciplinam o procedimento legislativo de revisão.

Parte da doutrina entende não ser própria a denominação constituinte atribuída ao poder de revisão, considerando que, na qualidade de poder instituído, é um poder jurídico, definido como competência. Sua natureza é, assim, inteiramente diversa daquela do poder originário, incondicionado, ilimitado e extraestatal.

Desse modo, tem-se que, quanto à natureza do poder derivado, não há polêmica ${ }^{244}$. Trata-se de um poder jurídico, o único jurídico dos poderes constituintes ${ }^{245}$. Seriam os taços típicos do poder constituinte derivado, segundo Ferreira Filho, a derivação, a subordinação e o condicionamento ${ }^{246}$.

Ferreira Filho estabelece que o poder constituinte é normalmente qualificado de originário, exatamente para contraposição com o Poder Constituinte instituído ${ }^{247}$. O autor estabelece que, além do poder de elaborar a constituição, há também um poder destinado a estabelecer normas com a mesma força das normas constitucionais $^{248}$, um poder de reforma.

Segundo Ferreira Filho, só faz sentido falar em poder de reforma relativamente às constituições rígidas, onde a simples interpretação pode não ser suficiente para atualizar o texto constitucional. A explicação do autor é precisa:

\footnotetext{
${ }^{244}$ FERREIRA FILHO, M. G. Ibidem, pg. 137.

${ }^{245}$ FERREIRA FILHO, M. G. Ibidem, pg. 137.

${ }^{246}$ FERREIRA FILHO, M. G. Ibidem, pg. 139.

${ }^{247}$ FERREIRA FILHO, M. G. Ibidem, pg. 134.

${ }^{248}$ FERREIRA FILHO, M. G. Ibidem, pg. 134.
} 
O poder de revisão assim só existe em relação às Constituições rígidas, aquelas Constituições cuja modificação tem um procedimento préordenado, um procedimento especial.

Desse modo, o Poder Constituinte ao estabelecer a Constituição, em regra geral, estabelece um poder Constituinte, instituído, que é um poder de revisão, o Poder incumbido de adaptar a Constituição a eventuais situações novas ${ }^{249}$.

Assim, teria o poder instituído, poder de revisão ou poder constituinte derivado o caráter de um poder estatal, fundamental para a permanência da nova constitucional mesmo em face de mudanças sociais que justifiquem a alteração do texto originário.

Em análise sobre a teoria geral da revisão constitucional, Baracho esclarece que a tradição americana do amending power tem sido tradicionalmente associada à reforma da constituição, "novidade" introduzida no constitucionalismo norte-americano no fim do século XVIII. Trata-se de uma associação imprecisa, pois, como esclarece o doutrinador, $a$ reforma da Constituição, na tradição europeia, é bem diferente da americana ${ }^{250}$.

$\mathrm{Na}$ tradição europeia, a reforma deve ser compreendida à luz da distinção entre constituição e lei constitucional. Sendo a carta constitucional uma norma jurídica, compreende-se que muitas questões encontram-se reguladas de maneira relativamente incompleta e aberta ${ }^{251}$, o que enseja o trabalho de atualização operado tanto pelo intérprete, como pelo legislador, mediante transformações na lei constitucional propriamente dita.

Desse modo, tem-se uma constituição escrita, rígida, protegida pela existência de cláusulas pétreas que constituem verdadeiras limitações materiais ao poder de revisão, exercido pelo poder legislativo, conforme um processo formal marcado por maiores dificuldades em comparação com o processo legislativo destinado à elaboração das leis infraconstitucionais.

Silva filia-se ao conjunto de doutrinadores que compreendem o poder constituinte apenas em sua dimensão originária. Isso porque o poder derivado, no dizer do autor, não é propriamente poder constituinte, mas competência para modificar a constituição existente - ou seja, poder constituinte derivado é simples competência constituinte ${ }^{252}$. O autor vai na

\footnotetext{
${ }^{249}$ FERREIRA FILHO, M. G. Ibidem, pg. 135.

${ }^{250}$ BARACHO, José Alfredo de Oliveira. Teoria Geral da Revisão Constitucional e Teoria da Constituição Originária, in Revista da Faculdade de Direito da UFMG, Belo Horizonte, v. 34, 1994, pg. 59.

${ }^{251}$ BARACHO, J. A. O. Ibidem, pg. 61.

${ }^{252}$ SILVA, José Afonso da. Poder Constituinte e Poder Popular. São Paulo: Malheiros, 2007, pg. 64.
} 
mesma linha argumentativa de Ferreira Filho, ao estabelecer a tradicional dicotomia entre poder originário e poder derivado no sentido atribuído pelos clássicos:

O poder de reforma constitucional - ou que nome tenha: poder de emenda, poder constituinte derivado -, por ser uma forma de poder constituído ou instituído, é poder regrado, condicionado e limitado. Nada mais é que uma competência instituída, na Constituição, para a produção de normas constitucionais derivadas, de acordo e dentro dos limites estabelecidos pela própria Constituição ${ }^{253}$.

Assim sendo, tem-se que, com a constituição moderna, que assume a forma escrita, dotada de rigidez e de superioridade hierárquica relativamente às demais normas legais, surge paralelamente o poder de revisão da carta constitucional, como estratégia de permanência e estabilidade do texto positivado. Servindo como mecanismo de atualização da norma constitucional, o poder de reforma é entendido como um poder instituído, regulado pela constituição, a ela subordinado e limitado tanto formal como materialmente.

Não se deve confundir, igualmente, a noção de permanência do poder constituinte originário com o poder de reforma da constituição. De acordo com a teoria clássica, a promulgação ou a outorga do texto constitucional não representam a extinção do poder constituinte, que subsiste como potência. Desse modo, tendo em vista sua relação com a soberania, o poder constituinte "é chamado" a agir sempre que houver um hiato entre a ordem constitucional e o anseio do soberano. Cada constituição positivada permanece vigente, assim, até que o poder constituinte originário seja chamado à ação uma outra vez. O poder de reforma, em contrapartida, parte da ideia de permanência da constituição, é o poder de atualizar, de renovar o texto à luz da mudança.

Febres-Cordero, em análise sobre a distinção entre o poder constituinte originário e o poder de revisão, ou poder constituinte instituído, apresenta uma distinção interessante entre os poderes gerais do Estado e a competência reformadora da constituição. Segundo o autor, inspirado na teoria organicista de Carré de Malberg, embora o poder derivado seja, em sua natureza, distinto do poder originário, ele ocupa uma posição diferenciada dentro do sistema normativo.

Haveria, assim, uma "gradação" de importância dos poderes (ou competências) dentro da ordem constitucional. Em primeiro lugar, tem-se o poder supremo, originário e ilimitado, o poder constituinte, que não seria, ainda, competência, por ser poder extraestatal. Já inserido na ordem jurídica, tem-se o poder de revisão da constituição, que é

${ }^{253}$ SILVA, J. A. Ibidem, pg. 231. 
hierarquicamente superior aos demais poderes instituídos. Como esclarece Febres-Cordero, em sentido prático, atribuir o poder de revisão a um indivíduo ou corporação implica outorgar-lhes uma situação política privilegiada no Estado, tendo tal poder uma preponderância inquestionável $^{254}$.

Conforme a concepção tradicional, a distinção entre poder constituinte originário e poder constituinte derivado é, portanto, de natureza, são poderes com características e dimensões distintas. Enquanto que o poder originário se situa no âmbito da política, onde a soberania é exercida a fim de provocar a criação da ordem jurídica e do Estado, o poder derivado é um poder de ação, competência estritamente delimitada e regulada por normas jurídicas já positivadas.

Carl Schmitt, por sua vez, partindo da distinção entre lei constitucional e Constituição, distingue o poder constituinte dos dispositivos legal-constitucionais destinados à reforma ou revisão do texto da carta constitucional ${ }^{255}$. Sendo a constituição obra do poder constituinte - a própria decisão fundamental, distinta portanto de sua expressão positivada, o texto, que pode ser alterado sem prejuízo da decisão triunfante, mostra-se coerente a compreensão do autor sobre a impropriedade de se atribuir o caráter constituinte ao poder de reforma da constituição.

Rigorosamente, só se pode atribuir o status de poder constituinte, de acordo com o preceituado na perspectiva clássica, ao poder de elaboração originária da constituição, razão pela qual se mostra mais adequada a denominação poder de reforma ou poder de revisão, ao invés da tradicional expressão poder constituinte derivado. Entendido este como competência, sua função é conferir plasticidade à constituição escrita, permitindo sua vigência para além do momento de criação. Uma vigência que simboliza a estabilidade institucional e a continuidade da ordem jurídica.

Neste trabalho, embora se chame a atenção para a distinção terminológica entre poder constituinte originário e poder constituinte derivado, utilizada pela doutrina tradicional, prefere-se qualificar como constituinte apenas o poder de elaboração originária da Constituição, no momento de ruptura com a ordem anterior. Havendo distinções consideráveis entre o fundamento e o exercício das duas "modalidades" de poder, não se

254 FEBRES-CORDERO, Jaime Buenahora. Filosofia e Historia del Poder Constituyente, in: UNIVERSITAS, N. 80, 1986, pg. 32.

${ }^{255}$ SCHMITT, Carl. Teoría de la Constitución. Madrid: Editorial Revista de Derecho Privado, 19??, pg. 106. 
mostra lógico o tratamento das duas categorias dentro da mesma unidade teórica, posto que as limitações e os fundamentos axiológicos para o constituinte originário ensejam a busca de alternativas para além do jurídico, no espaço de intersecção entre Direito e Política, enquanto que os condicionamentos do constituinte derivado, ou poder de reforma, estão inseridos na própria ordem positivada.

\subsection{Insuficiências da teoria clássica}

A teoria clássica sobre o poder constituinte, desenvolvida a partir da contribuição teórica de Sieyès no contexto do processo revolucionário francês, difundiu-se na doutrina do direito público continental, na qual se inserem culturas jurídicas herdeiras da matriz do civil law, como França, Portugal, Itália e Brasil. Nessa doutrina, o poder constituinte é entendido como a iniciativa (muitas vezes revolucionária) de fundação do estado de direito, mediante a instituição do modelo representativo e democrático, cuja obra principal é a elaboração de uma constituição escrita, rígida, que contemple a proteção às liberdades individuais e a estrutura da separação de poderes.

De acordo com a contribuição de Sieyès, sendo necessário superar as monarquias absolutistas e a rígida estrutura de classes no Estado francês, que impedia o pleno desenvolvimento da economia e o exercício da liberdade individual, mostrava-se sustentável a tese segundo a qual a nação é a verdadeira titular do poder político, podendo exercê-lo a qualquer tempo, inclusive para provocar a subversão da ordem jurídica, com a recriação do Direito a partir da mudança constitucional.

A constituição surge na Modernidade, portanto, como uma construção - o resultado do desejo da nação de transformar o direito excludente em direito da liberdade -, diminuindo consideravelmente o espaço de atuação do Estado, seja pela redução de suas competências, seja pela repartição de suas funções em "poderes" distintos: o Judiciário, o Legislativo, o Executivo. Nesse momento, o direito deixa de ser considerado um dado metafísico e assume um aspecto instrumental: o papel do Direito positivo é tornar realidade o Estado Liberal, o Estado das liberdades individuais. 
Ainda que não se possa afirmar que Sieyès construiu uma teoria rigorosa sobre o poder constituinte, dada a dimensão e o caráter eminentemente panfletário da obra, seu argumento mostrou-se útil para a difusão do discurso em defesa da revolução e da instituição do Estado de Direito, com a consequente elaboração das constituições liberais. Suas considerações sobre o poder constituinte da nação constam na quase totalidade das obras de sistematização doutrinária elaboradas pelos publicistas franceses desde o século XIX, o que é revelador da influência ideológica e teórica de Sieyès sobre a matéria. Quando se considera o poder constituinte no mundo ocidental moderno faz-se necessária referência ao título "O que é o Terceiro Estado" e a Sieyès.

O constitucionalismo moderno surge, portanto, estreitamente relacionado com o exercício do poder constituinte e com a ruptura com as ordens jurídicas tradicionais mediante a força do poder revolucionário da classe burguesa. A revolução operou-se não só no plano político, com a instituição do Estado Liberal, mas igualmente no plano filosófico, com o paradigma da filosofia do sujeito ilustrada pelo pensamento kantiano e no plano econômico, com a consolidação da economia de mercado e, já no século XIX, com a revolução industrial.

Uma nova forma de convivência social e organização política é inaugurada com a Modernidade, fundada do postulado da liberdade individual, consequência da verdadeira "descoberta" da categoria do sujeito. O poder constituinte é, assim, um dos vários temas do constitucionalismo que nasce com a Modernidade, o constitucionalismo liberal, estando portanto impregnado dos valores próprios dessa forma de convivência e organização.

Como esclarece Saldanha, com a Modernidade, o direito e o Estado foram objeto de uma nova concepção, relacionada com o advento do direito escrito como forma dominante nas nações europeias ${ }^{256}$. Essa relação é fundamental para a compreensão do nascimento do constitucionalismo, na medida em que as constituições liberais são compreendidas como normas escritas, construídas a partir da vontade de sujeitos que pretendem afirmar sua liberdade. Nesse sentido afirma Saldanha:

Enquanto no localismo medieval, tradicionalista e religioso, o direito se entendia em função da divindade e da comunidade, e o Estado era uma ordem teoricamente limitada embora podendo ser eventualmente esmagadora, os Estados nacionais modernos puseram como direito ordenações escritas, entendendo-se o direito como lei escrita e como

${ }^{256}$ SALDANHA, Nelson. Formação da Teoria Constitucional, $2^{a}$ edição. Rio de Janeiro: Renovar, 2000, pg. 121. 
comando provindo de vontades humanas determinadas: a do soberano, a da coletividade ${ }^{257}$.

O poder constituinte, nessa linha de raciocínio, assume a função de instrumentalizar a ação do soberano no trabalho de criação das normas escritas e, em especial, da constituição, carta política de afirmação das liberdades individuais e de limitação das competências do estado. Esse poder, portanto, foi concebido como um poder revolucionário, de completa superação de um modelo de organização social e política, simbolizado pelo estado absolutista.

Rigorosamente, com o direito positivo nascido da Revolução, tem-se a institucionalização de liberdades e prerrogativas entendidas como direitos naturais, responsáveis pela restrição do próprio Estado, sendo-lhe prévios, portanto. A ideia de que o homem possui direitos intrínsecos, vinda de outras épocas, torna-se mais consistente, e se desdobra na concepção de que tais direitos precisam ser consagrados em termos legislativos $^{258}$.

$\mathrm{Na}$ medida em que se constrói como um poder de ruptura, revolucionário, não reconhece a doutrina caráter jurídico ao poder constituinte, pois reconhecê-lo implicaria na aceitação de que normas prévias lhe condicionam o exercício, limitando-o. Qualquer direito prévio era, naquele contexto, considerado direito injusto, dado seu fundamento monárquico. Sendo o objetivo do poder constituinte da nação a refundação do Estado dentro de modelos democráticos, a completa ruptura normativa com a ordem anterior se mostrava indispensável. Como esclarece Febres-Cordero, deve-se aceitar que o poder constituinte tem como elemento derivado de sua natureza a insubordinação ${ }^{259}$.

Qualifica-se o poder constituinte, assim, como um poder originário, ilimitado, incondicionado. Originário posto que é anterior ao Estado, responsável mesmo pela sua criação, pela estruturação de sua forma e modo de funcionamento, conforme esclareceu Schmitt. Incondicionado, uma vez que seu exercício não está delimitado por normas de procedimento previamente estabelecidas e ilimitado porque pode disciplinar qualquer conteúdo da maneira que convier ao soberano.

\footnotetext{
${ }^{257}$ SALDANHA, Nelson. Ibidem, pg. 121.

${ }^{258}$ SALDANHA, Nelson. Ibidem, pg. 121.

259 FEBRES-CORDERO, Jaime Buenahora. Filosofia e Historia del Poder Constituyente, in: UNIVERSITAS, N. 80, 1986, pg. 24.
} 
Um aspecto fundamental da teoria clássica, responsável pelo advento do constitucionalismo contemporâneo, é a compreensão da constituição como uma construção, e não como um dado: a constituição deve ser feita, não está dada, é necessário um esforço de criação ${ }^{260}$, daí a coerência do postulado da ilimitação material e da incondicionalidade do poder constituinte no contexto revolucionário.

Apesar de coerente com o seu contexto de surgimento e propícia para o atendimento dos objetivos revolucionários, a teoria clássica é, hoje, insuficiente em vários aspectos. Superada está a necessidade de afirmação de um modelo novo de organização estatal. Após o auge do modelo liberal-burguês, de sua transformação para o estado social da primeira metade do século XX, é preciso reconhecer que os problemas constituintes de hoje são problemas teóricos de outra ordem.

Não é possível estabelecer um paralelo político entre o contexto das revoluções liberais - como movimento de afirmação de um conjunto uniforme de ideologias e valores - e o momento histórico vivido pelos estados após a Segunda Guerra Mundial, já no século $\mathrm{XX}$, quando as soberanias nacionais precisaram se reafirmar à luz das diversidades culturais, do nascimento dos blocos de países e da criação de uma ordem internacional supraestatal. Os problemas constitucionais, a permanência e a mutabilidade das ordens jurídicas e mesmo a revolução adquirem novos contornos, fazendo-se necessário analisar o problema do poder constituinte à luz da herança liberal, mas para além dela.

Indispensável, portanto, um esforço de atualização, renovando a preocupação com o discurso de fundamentação no Direito, a fim de a ação responsável pela criação das normas constitucionais não esteja inteiramente destituída de parâmetros. O direito, enquanto ciência que pretende ser, necessita justificar-se para além da força.

\subsection{Teoria clássica e suas releituras contemporâneas}

A teoria do poder constituinte tem passado, desde seu nascimento, por releituras e reanálises, especialmente em tempos de crise constitucional, a ponto de Klein a considerar um "verdadeiro continente", uma terra particular que é preciso abordar com cuidado para

${ }^{260}$ FEBRES-CORDERO, J. B. Ibidem, pg. 24. 
evitar seus perigos ${ }^{261}$. Constata-se que as releituras recentes surgem tanto de autores filiados à matriz teórica inglesa e americana, como daqueles que se orientam pelo desenvolvimento da teoria clássica de origem francesa. Neste item, busca-se apresentar, de forma não exaustiva, as questões que a literatura jurídica e filosófica têm levantado sobre o poder constituinte nos últimos anos.

Os autores europeus têm retomado os estudos sobre poder constituinte como uma necessidade decorrente da formação do bloco comum europeu, analisando a existência ou não de uma soberania transnacional e o seu modo de exercício. Já os estudos de ColónRíos e, em menor dimensão, os de Detlef Nolte e Almut Schilling-Vacaflor são representativos de reanálises construídas à luz de problemas mais locais, próprios da América.

Neil Walker e Martin Loughlin se empenham em formular uma revisão conceitual ampla no bojo de uma teoria geral do poder constituinte, mas partem seu trabalho conjunto com outros autores de uma apresentação da história conceitual enfrentada a partir da experiência europeia, razão pela qual sua obra pode perfeitamente dialogar com os postulados clássicos, constituindo, verdadeiramente, uma releitura de seus paradigmas fundamentais. Um aspecto fundamental pode ser indicado de sua obra: a identificação das origens conceituais sobre o poder constituinte não na França revolucionária, mas na Inglaterra do século XVII.

Loughlin, em especial, aponta a articulação originária do conceito de poder constituinte na Inglaterra. Reconhecendo que, apesar de sua origem inglesa, o conceito foi quase que "inteiramente erradicado" do discurso constitucional moderno britânico, Loughlin atribui esse desaparecimento ao colapso da tentativa republicana e à restauração da monarquia, quando se observou uma gradual institucionalização das modernas práticas do governo parlamentarista ${ }^{262}$.

O autor apresenta uma interpretação original para a inovação que está na base do surgimento de uma teoria sobre o poder constituinte inglesa: trata-se de uma mudança na lógica de justificação da autoridade constitucional. Essa autoridade encontra seu

\footnotetext{
${ }^{261}$ KLEIN, Claude. Inexistence ou disparition du pouvoir constituant? In: CAYLA, Olivier; PASQUINO, Pasquale (direc.). Le pouvoir constituant et l'Europe. Paris: Dalloz, 2011, pg. 39.

${ }^{262}$ LOUGHLIN, Martin. Constituent power subverted: from english constitutional argument to british constitutional practice. In: WALKER, Neil; LOUGHLIN, Martin (orgs). The paradox of constitutionalism: constituent power and constitutional form. Oxford: Oxford University Press, 2008, pg. 27.
} 
fundamento em uma força que vem não de cima, mas "de baixo", isto é, o poder último para instituir ou transformar os princípios de governo está com o povo ${ }^{263}$.

É preciso compreender, todavia, o real alcance da justificação popular da autoridade do estado empreendida pelo discurso político inglês do século XVII, já que a sobernia popular foi tomada como meio através do qual uma elite se imiscuiu no poder, exercendo sua autoridade "in the name of people" 264.

Apesar de promissoras, as teorizações sobre o poder constituinte não encontraram lugar na Inglaterra, em especial após a restauração da monarquia parlamentarista. Essa ausência ou silêncio pode ser atribuído às peculiaridades do sistema constitucional inglês, cuja figura da constituição não assume as feições clássicas de uma carta de direitos escrita e formal, no formato das constituições do liberalismo político.

Jaume, em contrapartida, analisa as origens sobre o debate acerca do poder constituinte na França, indicando que, para os revolucionários do século XVIII, a distinção entre poder constituinte e poderes constituídos estaria na fonte da legitimidade das instituições governamentais. Jaume aponta uma percepção fundamental no que tange à ideia de poder constituinte: a noção de que a soberania popular goza de certa "exterioridade" em relação às instituições, sendo-lhes superior. Esse caráter externo da soberania é que justifica a autonomia e a incondicionalidade do poder constituinte tal como concebido pelos teóricos franceses da revolução.

Na medida em que atuou como fato de legitimação do estado burguês construído com a revolução, o poder constituinte assume duas faces nas transformações observadas em 1789: revolucionário e criador; inovador e protetor. Revoluciona ao subverter a ordem política do estado absoluto e criador porque funda as bases de um novo modelo de estado, o estado liberal burguês. Inovador porque cria o direito conforme a razão, independentemente de uma autoridade divina, ao mesmo tempo em que protege os direitos individuais clássicos ${ }^{265}$.

Tradicionalmente associado à crise e à revolução, segundo o pesquisador francês, somente na década de 50 do século XX é que a teoria constitucional francesa se

\footnotetext{
${ }^{263}$ LOUGHLIN, Martin. Op. cit.

${ }^{264}$ LOUGHLIN, Martin. Ibidem, pg. 39.

${ }^{265}$ JAUME, Lucien. Constituent power in France: the revolution and its consequences. In: WALKER, Neil; LOUGHLIN, Martin (orgs). The paradox of constitutionalism: constituent power and constitutional form. Oxford: Oxford University Press, 2008, pg. 69.
} 
"reconcilia" com o poder constituinte, entendendo-o não como uma ameaça à estabilidade do estado, mas como um importante componente da legitimidade de sua autoridade. Jaume é peremptório ao afirmar que a doutrina legal francesa privilegiou a teoria de Sieyès e sua quase mística identificação entre o povo e a assembleia constituinte ${ }^{266}$.

O italiano Antonio Negri é a referência principal quando se pensa na relação entre poder constituinte e revolução, uma vez que, para o autor, todos os processos revolucionários empreendidos desde a modernidade constituem um progressivo desenvolvimento e expressão de um mesmo conceito: o poder constituinte. De acordo com Negri, o poder constituinte é considerado não apenas como um poderoso e expansivo princípio capaz de produzir as normas constitucionais de qualquer sistema jurídico, como também o próprio sujeito dessa produção ${ }^{267}$.

Para Negri, o poder constituinte precisa ser estudado e compreendido a partir de uma perspectiva jurídica, ainda que se reconheçam as dificuldades de se "constitucionalizar" o conceito de um poder originário e fundamental, o poder de criar competência ou autoridade. O conceito convive com uma crise que constitui um verdadeiro paradoxo: a democracia, como uma teoria do governo absoluto, precisa conviver com o constitucionalismo, como teoria da limitação do poder.

O caráter extraordinário do poder constituinte, sua ocorrência episódica, indica que o tempo de seu exercício se caracteriza por uma formidável capacidade de aceleração: é preciso definir, categorizar, limitar as normas jurídicas e as instituições básicas da vida cotidiana do Estado. Através desse ato fundacional que representa a constituição, o poder constituinte se incorpora no poder constituído ${ }^{268}$. As contribuições de Negri, em especial sua análise sobre a permanência e a temporalidade do poder constituinte, serão retomadas no último capítulo, quando se propõe uma releitura da teoria do poder constituinte hoje.

O estudioso Pasquale Pasquino, especialista na obra de Sieyès, aponta o surgimento doutrinário do conceito de poder constituinte não na França, mas nos estudos de George Lawson, na Inglaterra. Para o intérprete, o conceito de poder constituinte só faz sentido no

\footnotetext{
${ }^{266}$ JAUME, Lucien. Ibidem, pg. 84.

${ }^{267}$ NEGRI, Antonio. Insurgencies: constituent power and modern state, traduzido por Maurizia Boscagli. Minneapollis: University of Minnesota Press, 1999, pg. 1.

${ }^{268}$ NEGRI, Antonio. Ibidem, pg. 3.
} 
bojo da dicotomia entre poder constituinte e poderes constituídos, na medida em que aquele é a fonte e o limite do segundo ${ }^{269}$.

Pasquino, ao analisar a gênese do conceito conjuntamente com o desenvolvimento da teoria constitucional anglo-americana, chega a conclusões interessantes, que vão, em certa medida, ao encontro do argumento deste trabalho. Segundo ele,

O poder constituinte do povo não remete nem a um poder sem limites, nem a um procedimento específico ligado ao processo de elaboração da constituição, mas a um princípio, qual seja o princípio da forma moderna de um poder limitado ou separado, o qual se sustenta na existência aceita e compartilhada de uma constituição rígida ${ }^{270}$.

O entendimento do autor é inovador, mas merece crítica. Se não se pode conceber o poder constituinte como poder ilimitado, é questionável a sua autonomia em relação ao procedimento de elaboração da constituição. Do mesmo modo, o poder constituinte não pode se sustentar na existência de uma constituição rígida quando ele é o próprio motor de sua criação, justamente a partir de um processo de deliberação que culmina na aprovação do texto final da carta.

A relação entre poder constituinte e os seus limites está, para Le Pillouer, na gênese do seu conceito, isso porque o poder constituinte detém duas funções, que, embora diferentes, estão profundamentamente ligados: ele permite, de uma parte, justificar os limites que se pretende impor ao legislativo; e permite, de outra parte, justificar a ausência de limites de que os autores da constituição desejam se beneficiar ${ }^{271}$.

Nolte e Schilling-Vacaflor analisam o poder constituinte a partir da experiência constitucional enfrentada pelas democracias recentes da América Latina e, indiretamente, dos países do continente africano, asiático, além dos países herdeiros do socialismo soviético. Para os autores, constata-se que as teorizações sobre a constituição e sobre a dinâmica constitucional desenvolvidas a partir dos problemas latino-americanos, e mesmo a experiência política concreta das nações do mundo subdesenvolvido do Sul, têm tido mais influência sobre os novos processos constituintes do globo do que propriamente a experiência europeia. Isso porque o constitucionalismo latino-americano é um

\footnotetext{
${ }^{269}$ PASQUINO, Pasquale. Le pouvoir constituent, le gouvernement limité et ses origines dans le Nouveau Monde. In: CAYLA, Olivier; PASQUINO, Pasquale (direcs). Le pouvoir constituant et l'Europe. Paris: Dalloz, 2011, pg. 49

${ }^{270}$ PASQUINO, Pasquale. Ibidem, pg. 60.

${ }^{271}$ LE PILLOUER, Arnaud. Reconstitution(s) du pouvoir constituant. In: CAYLA, Olivier; PASQUINO, Pasquale (direcs). Le pouvoir constituant et l'Europe. Paris: Dalloz, 2011, pg. 71.
} 
constitucionalismo que precisa conviver com debilidades não só políticas, mas econômicoculturais, o que de certo modo favorece o diálogo com os problemas constituintes desses novos Estados $^{272}$.

De acordo com Colón-Ríos, o poder constituinte pode ser entendido como o ponto de contato perdido no debate sobre o constitucionalismo e a democracia ${ }^{273}$. Analisando o caso recente da Venezuela, quando o povo foi diretamente consultado pelo governo eleito sobre a instituição de uma assembleia constituinte, Colón-Ríos reconhece a existência de uma tensão entre a ordem jurídica positivada e o ideal democrático de uma autodeterminação radical. Naquela ocasião, a suprema corte Venezuela precisou decidir se a invocação do referendum era legítima e, portanto, válida, na medida em que contrária à ordem jurídica estabelecida. Reconhecendo a existência de um ponto de tensão entre o constitucionalismo e a democraciaa, a corte entendeu que o procedimento de reforma só condiciona a atividade do parlamento e não o exercício do poder constituinte pelo povo soberano, o que culminou com a declaração da validade do referendum realizado ${ }^{274}$.

Para o autor, a decisão da corte venezuelana é paradigmática, na medida em que reconhece não ser o exercício da democracia uma afronta ao estado de direito, mas o meio através do qual o próprio estado se constitui. Em concordância com essa ideia, é preciso reconhecer que foi fundamental para o desenvolvimento da concepção moderna de poder constituinte, apresentada por Sieyès, o aporte teórico de John Locke e George Lawson para o direito de resistência ${ }^{275}$. Colón-Ríos vai ao encontro da interpretação tradicional ao reconhecer o contratualismo como a fonte filósofica que fundamental a teoria do poder constituinte.

Em Locke, indica Colón-Ríos, já pode ser percebida a nota de excepcionalidade atribuída à ideia constituinte, uma vez que o supremo poder de elaborar a constituição só pode ser exercido em situações de extrema injustiça ${ }^{276}$. O autor reconhece o caráter panfletário da obra de Sieyès e suas limitações, não se pondendo considerar "O que é o terceiro estado" verdadeiramente uma sistematização exaustiva sobre o poder constituinte. Apesar disso, o valor da obra é inegável, em especial no que tange à ideia de que o

${ }^{272}$ NOLTE, Detlef; SCHILLING-VACAFLOR, Almut. New Constitutionalism in Latin America: Promises and Practices. Surrey: Ashgate, 2012.

${ }^{273}$ COLÓN-RÍOS, Joel I. Weak Constitutionalism: Democratic legitimacy and the question of constituent power. New York: Routledge, 2012, pg. 152.

${ }^{274}$ COLÓN-RÍOS, Joel I. Ibidem, pg. 80.

${ }^{275}$ COLÓN-RÍOS, Joel I. Op. cit.

${ }^{276}$ COLÓN-RÍOS, Joel I. Ibidem, pg. 82. 
exercício do poder constituinte não esgota a soberania, que permanece latente, podendo, a qualquer momento, voltar a ser invocada ${ }^{277}$.

Colón-Ríos observa que, na prática constitucional do século XX, nem sempre a teoria do poder constituinte, tomada em seu sentido original, é respeitada. Isso porque, não só as constituições são adotadas em contextos nos quais a assembleia constituinte não está livre para adotar a constituição que deseja, como algumas constituições são outorgadas sob ocupação militar. Constata-se um baixo nível de participação popular em várias experiências específicas, mesmo nas democracias mais maduras do mundo europeu. Apesar disso, o autor acredita que, em particular na América Latina, as mudanças constitucionais recentes têm levado a sério as implicações da teoria clássica do poder constituinte. Como menciona:

Em verdade, o fato de que a prática constituinte e as reformas constitucionais são frequentemente inconsistentes com a teoria do poder constituinte não significa que ela precisa ser descartada. Para levar em conta um aspecto mínimo, o conceito de poder constituinte oferece indicações sobre como as constituições devem ser criadas e recriadas na democracia; sobre como o regime constitucional deve se aproximar da soberania do povo $^{278}$.

A passagem é esclarecedora e justifica a relevância de um estudo sobre o poder constituinte hoje, além de reconhecer que os postulados básicos sobre a temática apresentados pela contribuição teórica clássica ainda persistem tanto na prática como na literatura acerca do poder constituinte. Pela releitura de Colón-Ríos, a preocupação teórica com o poder constituinte é, fundamentalmente, uma preocupação de tradições jurídicas herdeiras do civil law.

$\mathrm{O}$ autor compreende que a teoria do poder constituinte foi desenvolvida à luz da tradição das constituições escritas do liberalismo clássico de matriz francesa, o que explica as poucas referências ao tema na teoria constitucional inglesa e americana. Para a tradição inglesa, o poder constituinte é entendido como conceito estrangeiro, que pertence a países com constituições escritas e sistematizadas, em que se observa uma distinção entre a ação do legislador e o povo soberano ${ }^{279}$.

Colón-Ríos pontua que, nos Estados Unidos, não há sequer a referência ao termo "poder constituinte" na literatura dos primeiros anos do constitucionalismo. Mesmo nos

\footnotetext{
${ }^{277}$ COLÓN-RÍOS, Joel I. Ibidem, pg. 86.

${ }^{278}$ COLÓN-RÍOS, Joel I. Ibidem, pg. 89.

${ }^{279}$ COLÓN-RÍOS, Joel I. Op. cit.
} 
estudos americanos contemporâneos, não se encontra com facilidade referências à teoria do poder constituinte (ou mesmo indicação de sua existência) nos trabalhos da grande maioria dos pesquisadores. A mudança de tratamento no tema entre os Estados Unidos e Inglaterra, de um lado, e a América Latina e países da Europa continental, de outro, pode ser explicada pela conexão que o conceito tem com o modelo de sistema político empregado nos países componentes deste último bloco ${ }^{280}$.

As preocupações teóricas com o poder constituinte também são resultado de um panorama de instabilidade política provocada pela fraqueza do ideário liberal nas nações subdesenvolvidas da América Latina. Ao contrário dos Estados Unidos, onde o modelo liberal de estado de direito encontrou seu lugar sem maiores rupturas institucionais, a história dos estados do sul é uma história permeada de avanços e retrocessos em matéria de liberdade e democracia.

Loughlin, por sua vez, analisando o poder constituinte sob a ótica parlamentarista, também reconhece que o conceito de poder constituinte pressupõe uma distinção entre o pacto criador da unidade política e o "contrato constitucional" que estabelece a constituição do gabinete, em outras palavras, entre as normas fundamentais e a legislação ordinária. A relação entre o poder constituinte e o povo - identificado como seu titular universal - se deve, de acordo com o autor, à modernidade do conceito ${ }^{281}$.

As inúmeras releituras apresentadas dialogam, em maior ou menor grau, com os principais postulados do poder constituinte edificados no advento da Modernidade. Observa-se uma linha de raciocício que permanece bastante homogênea, notadamente no que tange à compreensão das relações entre sociedade e estado. Os capítulos subsequentes buscam abordar de forma reflexa as insuficiências da visão tradicional, propondo uma atualização da teoria clássica.

Em primeiro lugar, é preciso discutir a relação entre a titularidade do poder constituinte, a legitimidade da constituição e a legalidade: o poder constituinte é um poder do povo, democrático, portanto, ou é um poder de ocasião, no sentido que o deterá a força política triunfante, seja ela democrática ou não? Mostra-se sustentável jurídica e politicamente uma constituição elaborada com base no projeto criado e defendido por uma

\footnotetext{
${ }^{280}$ For them, constitutional law is parto $f$ the more general field of derecho politico (literally translated, 'political law'. COLÓN-RÍOS, Joel I. Ibidem, pg. 91.

${ }^{281}$ LOUGHLIN, Martin. Foundations of Public Law. Oxford: Oxford Press, 2012,pg. 38 [formato e-book].
} 
minoria? Qual é a relação, portanto, entre a teoria do poder constituinte e a teoria democrática?

Embora desde a Modernidade poder constituinte e democracia tenham caminhado, pelo menos em teoria, juntos, a relação não é de todo evidente, o que faz com que vários autores reconheçam a existência de constituições provenientes de movimentos oligárquicos ou de legitimidade duvidosa, tal como aquele vivido por ocasião da ditadura militar no Brasil. Tem-se que, em termos constitucionais, a legalidade - entendida, aqui, como processo de positivação - não está dissociada da legitimidade, entendida como consentimento, adesão, reconhecimento do povo em relação à legalidade instituída.

No bojo de tais indagações sobre poder constituinte está o questionamento sobre a legitimidade das ordens jurídicas, desde o seu começo, simbolizado pela criação da carta constitucional. Na medida em que a preocupação fundamental deste trabalho é com a justificação racional dos comandos constitucionais, descobrir o que torna uma norma jurídica legítima é o primeiro passo rumo a sua fundamentação, posto que a aceitabilidade racional de uma norma pressupõe o reconhecimento de sua importância para a paz e a ordem social. Considerando que a legitimidade é condição de efetividade, com a definição do titular do poder constituinte é possível indicar o caminho da legitimidade e, por consequência, o caminho da fundamentação e da efetividade das ordens constitucionais.

Igualmente problemática é a sustentabilidade da ilimitação material do poder constituinte originário. Considerando a afirmação histórica das liberdades públicas e das garantias fundamentais, os esforços pela institucionalização do Estado de Direito e da democracia, é possível sustentar que o poder constituinte pode disciplinar qualquer matéria de qualquer modo, tendo em vista seu caráter soberano, ilimitado e incondicionado? O princípio jurídico da proibição do retrocesso, já considerado norma implícita no ordenamento, pode ser utilizado como um princípio geral de justiça a fim de limitar o poder de ação do constituinte originário?

Como, então, resolver tais insuficiências?

A saída parece estar na consolidação da democracia no pós-guerra mundial, na qualidade de forma de organização propícia para a preservação das liberdades, a busca do bem-estar social e para a mediação dos conflitos sociais provenientes da diversidade cultural. A democracia é, então, defendida ela mesma como um direito dos povos, por 
proporcionar o direito de participação por meio do reconhecimento da diferença e da necessidade do diálogo como pressuposto para o consenso.

Apesar da importância institucional da democracia para ampliação do âmbito de proteção dos direitos e liberdades ser intuitiva, é fundamental demonstrar porque a democracia é, sobretudo, uma exigência racional, um imperativo de organização que torna viável o estado de direito almejado pelo mundo ocidental no pós-segunda guerra. A democracia é, assim, internalizada nos sistemas políticos não apenas por conta de um anseio popular, mas por sua coerência com o paradigma de racionalidade consolidado pela filosofia do século XX.

Essa noção se sustenta a partir da análise da reviravolta linguístico-pragmática e da compreensão do papel do diálogo para o conhecimento sobre o mundo. A filosofia acaba por transformar o paradigma moderno da racionalidade subjetal pelo paradigma da racionalidade dialogal, no qual se tem a interação comunicativa entre sujeitos como médium para o desenvolvimento científico e para a construção de consensos sobre a moralidade e o direito, o que será analisado com maiores detalhes no capítulo seguinte.

O modelo democrático, ao institucionalizar o reconhecimento da igualdade dos sujeitos, garantindo-lhes o direito de participação nas deliberações políticas, passa a permear todo o universo público, ainda que não estritamente estatal. É o que se percebe com espaços como a escola e, em especial, a universidade, cuja estrutura administrativa tem se transformado nas últimas décadas para incluir nos processos decisórios membros da comunidade estudantil e de apoio administrativo.

Essa internalização da democracia nos espaços públicos é decorrência, como se pretende demonstrar, da reviravolta linguística e da transformação do paradigma filosófico que consolidou a razão dialogal.

No capítulo subsequente, apresenta-se a reviravolta linguistico-pragmática da linguagem, como aporte teórico necessário para uma teoria propositiva e democrática do poder constituinte. 


\section{A REVIRAVOLTA LINGUÍSTICO-PRAGMÁTICA E A MUdANÇA DE PARADIGMA NA RACIONALIDADE JURÍDICA}

No capítulo anterior, restou demonstrado que a perspectiva clássica sobre o poder constituinte não se apresenta satisfatória frente às novas exigências normativas e constitucionais oriundas do pós-guerra. $\mathrm{O}$ estado de direito liberal, em sua pretensão de restringir a ação estatal em benefício da autonomia individual, precisou ser reformulado para dar conta de uma pluralidade de demandas por serviços e prestações sociais, como educação e saúde. O estado, assim, pensado para ser "mínimo", transforma-se para agir na compensação das desigualdades.

Em verdade, percebe-se que a história do estado de direito tem sido uma história de adaptações e releituras. O desenvolvimento da ideia de estado como uma estrutura composta e fortemente limitada pela ordem jurídica nasce com as revoluções liberais e se insere em uma ordem social marcada pelos conflitos e tensões sociais. O objetivo burguês de conter o poder estatal através do direito precisa dar conta de uma pretensão de legitimidade inerente às formas políticas oriundas da Modernidade, nas quais os estados existem para conduzir a sociedade no caminho da autonomia e das liberdades públicas.

Para Vaz, a sociedade política, em seu processo de desenvolvimento, vê-se face a face com o problema da legitimação consensual do poder. O iluminismo e a filosofia política forjada a partir da era moderna compreendem a relação entre estado e sociedade com a mediação do direito, que funciona como elemento de contenção do poder e de legitimação de seu exercício, por consequência ${ }^{282}$.

A função principal do estado criado pelo burguês oitocentista é justamente a preservação de um âmbito de liberdade individual, assegurada pelos direitos clássicos de primeira geração. Na medida em que a simples preservação das liberdades públicas mostrou-se insuficiente para garantir a liberdade, fez-se necessário reconhecer a existência

\footnotetext{
${ }^{282}$ VAZ, Henrique C. de Lima. Escritos de filosofia II: Ética e Cultura, 4a edição. São Paulo: Loyola,
} 2004, pg. 137. 
de outras "dimensões" dos direitos fundamentais, relacionados à existência social do indivíduo.

Habermas chama atenção para o paradigma da indivisibilidade dos direitos fundamentais, que mantêm entre si um vínculo lógico. Para o autor, os direitos fundamentais apenas podem resgatar politicamente a promessa moral de respeitar a dignidade humana de cada um se eles interagirem igualmente em todas as suas categorias $^{283}$. O estado de direito assume a responsabilidade não apenas pela garantia e regulamentação dos direitos próprios do liberalismo, mas igualmente dos direitos de segunda, terceira e quarta dimensão, gerando uma confluência de interesses geradora de tensão em potencial.

Para o filósofo alemão, quando o estado se restringe a garantir as liberdades econômicas, há uma destruição do equilíbrio existente entre os direitos fundamentais. Isso porque experiências de exclusão, sofrimento e discriminação ensinam que os direitos fundamentais clássicos só adquirem "um valor igual” (Rawls) para todos os cidadãos quando acrescidos de direitos sociais e culturais $^{284}$. Fundamental, portanto, que o estado seja capaz de dar conta de todas as dimensões dos direitos, sob pena de intensificar o processo de exclusão social e de destruição dos vínculos que mantém a unidade estatal.

O estado de direito está, segundo Neves, submetido a uma crescente tensão, revelando-se, muitas vezes, impotente. Para o autor, tem-se dois flancos de pressão que limitam suas possibilidades de realização, a prevalência da ordem mundial que se orienta pela economia e pela técnica, além da fortificação das etnias locais e dos fundamentalismos. Tem-se, em suma, uma progressiva destruição dos vínculos de fraternidade, seja pelo predomínio do poder econômico, seja pela ausência de referenciais éticos comuns ${ }^{285}$.

A superação da tensão a que se refere Neves é condição de permanência desse modelo de sociedade que se funda na democracia e na proteção dos direitos humanos, ou fundamentais. O grande esforço da teoria constitucional hoje é, assim, propor um modelo de legitimação do estado de direito.

283 HABERMAS, Jürgen. O conceito de dignidade humana e a utopia realista dos direitos humanos, in Sobre a Constituição da Europa. São Paulo: Editora UNESP, 2012, pg. 15.

${ }^{284}$ HABERMAS, Jürgen. Ibidem, pg. 16.

${ }^{285}$ NEVES, Marcelo. Entre Têmis e Leviatã: Uma relação difícil. São Paulo: Martins Fontes, 2008. 
Ao reunir as competências para execução de políticas públicas de índole social, o estado assume uma função proeminente no reforço dos vínculos de solidariedade e acaba por absorver todas as tensões e conflitos originados da sociedade, notadamente no que tange à matéria constitucional. A organização do estado, assim, precisa ser capaz de realizar não só a tarefa de regulamentação normativa, mas de estruturação das políticas sociais, ao mesmo tempo em que promove a mediação entre as expectativas sociais.

Para canalizar e absorver os conflitos, conduzindo-os de forma a evitar a desintegração e a destruição dos vínculos de solidariedade, o Estado precisa assumir uma nova identidade: democrática, inclusiva, aberta à tensão, ao considerá-la como inerente à sociedade hipercomplexa. A estrutura do estado democrático é dependente, portanto, de procedimentos constitucionais - sejam eles relacionados à atividade legislativa, judicial ou administrativa - voltados à promoção do diálogo entre as diversas pretensões normativas em conflito na esfera pública. Como esclarece Neves,

Isso significa que o processo democrático de tomada de decisão política, no sentido de formação da maioria, passa a constituir variável estrutural da reprodução dos procedimentos jurídicos de solução e absorção de conflitos, inclusive na medida em que a produção de normas jurídicas legislativas fica dependente das decisões políticas deliberadas democraticamente e tomadas majoritariamente ${ }^{286}$.

A constituição, em sua função fundadora, é o ato que institucionaliza os procedimentos da democracia, organizando-os. Mas qual a relação entre o poder constituinte, a nova identidade estatal e a exigência de procedimentos inclusivos e democráticos? É pelo poder constituinte que a teorização sobre a estrutura do estado ganha corpo, torna-se realidade política e jurídica, através do nascimento da carta constitucional.

O poder constituinte é o momento da criação do corpo normativo que dará vida aos procedimentos democráticos. É na elaboração da constituição que a identidade do estado é moldada, a partir de uma visão de sociedade e de poder. Para pensar os limites e as (novas) funções da constituição, é preciso partir da reflexão sobre o poder constituinte em si mesmo.

Neste trabalho, parte-se da constatação que a teorização tradicional sobre poder constituinte - que o identifica como a potência ilimitada, originária e incondicionada - não é capaz de oferecer uma saída segura para as necessidades que as novas constituições precisam atender: a de permitir a coexistência de grupos, interesses e valores tão díspares

${ }^{286}$ NEVES, Marcelo. Transconstitucionalismo. São Paulo: Martins Fontes, 2009, pg. 57. 
quanto conflitantes sem que dita coexistência implique a destruição da unidade do estado. É esse pressuposto que nos permite concluir que a organização democrática é a saída possível para o impasse da Modernidade: o impasse da falta de um parâmetro moral comum, o impasse da pluralidade de eticidades.

O advento da democracia está inserido em um caminho de transformações não só políticas e sociais, mas principalmente filosóficas. Neste capítulo, pretende-se demonstrar como a transformação do paradigma da racionalidade na filosofia ocidental foi responsável pelo advento da proposta teórica habermasiana e, também, de um modo geral, do discurso pela defesa da democracia e dos direitos fundamentais.

A transformação do sentido de razão representa a morte de uma subjetividade isolada, "monológica", e o nascimento do conceito de eu que se reconhece enquanto tal a partir de sua relação com o outro. Tem-se, aí, a "descoberta" da linguagem como categoria filosófica, de sua importância para o conhecimento do mundo, uma vez que o sujeito que conhece é moldado linguisticamente, em uma interação dialógica. Essa transformação é conhecida na literatura filosófica como uma verdadeira reviravolta no pensamento ocidental, uma reviravolta linguística.

Desse modo, a reviravolta linguístico-pragmática se insere num contexto de transformação do paradigma filosófico da subjetividade. A partir do desenvolvimento da filosofia da linguagem, propõe-se uma superação da razão monológica apresentada por Kant em sua Crítica da Razão Pura por uma razão dialogal, fundada nas bases da comunicação e do entendimento. O conhecimento é o resultado do diálogo entre dois sujeitos racionais que, através da interação discursiva, constroem, a partir da linguagem, o significado dos objetos cognoscíveis.

A racionalidade comunicativa advinda dessa transformação de pensamento é o cerne da democracia contemporânea. A democracia não só é uma opção: é o modo de institucionalização da razão pelo diálogo. Propõe-se, assim, pensar uma releitura do direito por meio da contribuição da filosofia, no sentido de pensar a validade das normas constitucionais como o resultado de um discurso racional e fundamentado, na qual se pressupõe a democracia como modelo de organização social e político que melhor realiza o paradigma de racionalidade dialogal. 
Seguindo o percurso argumentativo da tese, o objetivo específico deste capítulo é, portanto, demonstrar a "virada" no pensamento que representou o reconhecimento do diálogo como elemento fundador do próprio conhecimento, por ser constitutivo da racionalidade: do modo como o ser humano constrói e dá significado ao mundo e à sua relação com o outro. A teoria da sociedade e do direito em Habermas é, assim, um "resgate" do projeto iluminista, na medida em que acredita no potencial transformador da razão no movimento de dar sentido e ordem ao mundo vivido.

A compreensão dessa virada é importantíssima, posto que, a partir da construção da filosofia da linguagem, a democracia se mostra não só desejável, no sentido de uma escolha política, mas exigível, na qualidade de um imperativo racional: é a democracia que permite o diálogo, através de procedimentos inclusivos, que absorvem as expectativas e as tensões sociais, assegurando que os homens tenham a vida política organizada sem arbítrio.

Propõe-se, então, como forma de compreender essa transição e situá-la no bojo do referencial teórico habermasiano, a apresentação do paradigma da racionalidade monológica, tal como pensada por Kant, e o horizonte da virada linguística, que representou a transformação a que se referiram os parágrafos anteriores.

\subsection{O Paradigma da Razão Monológica: A Teoria do Conhecimento em Kant}

É possível estabelecer um marco para a teoria da ciência e para a metafísica depois de Kant. Com o advento de sua teoria do conhecimento, Kant revolucionou a compreensão da relação existente entre sujeito e objeto, própria do ato de conhecer, o que teve consequências fundamentais para a "descoberta" do sujeito como parte ativa e determinante na atividade científica. Com Kant, tem-se o advento de um novo paradigma de racionalidade, o paradigma moderno, focado na subjetividade e nas condições necessárias do ato de conhecer, transcendentes a qualquer experiência.

Em sua Crítica da Razão Pura, Kant busca estabelecer as condições de possibilidade do conhecimento. Interessou-se o filósofo alemão por compreender os mecanismos através dos quais os objetos do mundo podem ser conhecidos, isto é, como opera a razão em sua função de dar sentido. 
Para Kant, a investigação da faculdade do entendimento é fundamental: ela se propõe à determinação das regras e limites de seu uso. As indagações sobre o ato de conhecer têm como objetivo primordial levar a ciência de volta a um "caminho seguro", isto é, ao caminho da razão (CRP, B VII). Isso porque, como afirma Kant:

A tarefa principal desta crítica da razão pura especulativa reside nessa tentativa de modificar o procedimento até hoje adotado na metafísica, e isso de tal modo que operemos uma verdade revolução mesma a partir do exemplo dos geômetras e dos pesquisadores da natureza. Ela é um tratado do método, não um sistema da própria ciência; mas ela circunscreve ao mesmo tempo o seu inteiro contorno, tanto com relação aos seus limites quanto com relação a toda a sua estrutura interna (CRP, B XXIII) ${ }^{287}$.

A pergunta fundamental que inquieta $o$ filósofo é justamente esta: independentemente de toda experiência, o que e como podem o entendimento e a razão conhecer? (CRP, A XVII) ${ }^{288}$. Por isso sua reflexão é transcendental, ou pura, pois se preocupa com as condições a partir das quais se pode conhecer, independentemente do objeto; o conhecimento considerado, portanto, a priori (a razão pura é aquela que contém os princípios para conhecer algo absolutamente a priori ${ }^{289}$ ).

A resposta está relacionada à compreensão do conhecimento como experiência fenomênica. Em outras palavras, aquilo que chega à subjetividade que conhece é o fenômeno, apenas uma manifestação da coisa-em-si; o objeto permanece inacessível em sua existência puramente objetiva. Nas palavras de Kant, resta demonstrado em sua crítica que nós não possamos ter qualquer conhecimento das coisas em si mesmas, mas apenas enquanto objetos da intuição sensível (CRP, B XXVI) ${ }^{290}$. Mas como o fenômeno é percebido pela razão?

Segundo Kant, o conhecimento começa com a experiência, que estimula os sentidos no sentido da compreensão de um determinado objeto, mas não surge apenas dela, na medida em que depende de condicionantes apriorísticos próprios do exercício da subjetividade. O objeto, em suma, regula-se pela constituição da nossa faculdade intuitiva (CRP, B XVII) ${ }^{291}$, que interfere ativamente em todo o processo apenas provocado pela observação do fenômeno.

\footnotetext{
287 KANT, Immanuel. Crítica da Razão Pura, tradução e notas de Fernando Costa Mattos. Petrópolis: Vozes, 2012, pg. 33.

${ }^{288}$ KANT, Immanuel. Ibidem, pg. 21.

${ }^{289}$ KANT, Immanuel. Ibidem, pg. 59.

${ }^{290}$ KANT, Immanuel. Ibidem, pg. 34.

${ }^{291}$ KANT, Immanuel. Ibidem, pg. 30.
} 
A constituição de tal faculdade intuitiva, conforme a expressão kantiana, é formada por categorias como o tempo, o espaço e o princípio da causalidade, indissociáveis do processo cognitivo. Para Kant, as categorias do espaço e tempo, ou mesmo a relação de causalidade, são "hábitos mentais" presentes em todo e qualquer ato de conhecer. Transcendentes, por assim dizer, para usar a terminologia empregada pelo autor. Não é possível conceber a experiência - e, por conseguinte o conhecimento - fora do tempo, fora do espaço, ou independentemente das relações causais estabelecidas pela inteligência.

Tais elementos apriorísticos são próprios do fenômeno, e não da coisa em si. Existem apenas na experiência sensível vivida pelo sujeito, e não no mundo como realidade objetiva e independente do homem. O mundo da causalidade, organizado espacial e temporalmente, é o mundo para o homem, e não o mundo em si mesmo considerado, o qual é de todo inacessível à subjetividade. Não se sabe como o mundo é fora do "eu", fora do sujeito. Kant se indaga:

O tempo não pode ser intuído externamente, assim como o espaço não o pode como algo em nós. O que são então o espaço e o tempo? São entes reais? São apenas, de fato, determinações, ou mesmo relações das coisas, mas tais que pertenceriam às próprias coisas mesmo que não fosse intuídas? Ou são tais que só se ligam à forma da intuição e, portanto, à constituição subjetiva da nossa mente, sem a qual esses predicados não poderiam ser atribuídos a coisa alguma? (CRP - B 38) ${ }^{292}$

O "espaço", portanto, é uma representação necessária a priori que serve de fundamento a todas as intuições externas. Isso porque ele é considerado como a condição de possibilidade dos fenômenos, e não como uma determinação deles dependente (CRP B 39) $)^{293}$. O espaço não é uma propriedade do mundo, mas um condicionante a partir do qual o fenômeno é observado. Do mesmo modo, a categoria do tempo, que se relaciona com as noções de simultaneidade e sucessão, também é insuperável. A noção da passagem do tempo é uma representação necessária que serve de fundamento a todas as intuições $(\mathrm{CRP}-\mathrm{B} 46)^{294}$. A explicação é bastante intuitiva:

O tempo não é um conceito empírico que tenha sido derivado de alguma experiência. Pois a simultaneidade e a sucessão não se apresentariam à percepção caso a representação do tempo não lhes servisse a priori de fundamento. Somente sob a sua pressuposição se pode representar que algo seja em um mesmo e único tempo (ao mesmo tempo) ou em diferentes tempos (um após o outro). (CRP - B 46) ${ }^{295}$

\footnotetext{
${ }^{292}$ KANT, Immanuel. Ibidem, pg. 73.

${ }^{293}$ KANT, Immanuel. Ibidem, pg. 74.

${ }^{294}$ KANT, Immanuel. Ibidem, pg. 79.

${ }^{295}$ KANT, Immanuel. Ibidem, pg. 79.
} 
O conhecimento é, portanto, a organização da experiência do mundo. Conforme esclarece Oliveira, a tarefa de Kant consiste em analisar nossos conceitos apriorísticos. Isso porque, para Kant, a filosofia é um saber das condições de possibilidade do conhecimento humano de objetos e, por consequência, um saber sobre os "limites" deste conhecimento $^{296}$.

A filosofia kantiana parte da constatação de que a ontologia tradicional, moldada pelos mestres da filosofia grega, não é suficiente para explicar o processo cognitivo, na medida em que não considera qual é o papel do sujeito em sua atividade cognoscente, uma tarefa ativa, que condiciona os resultados do ato de conhecer. Oliveira esclarece a intuição fundamental de Kant, com as seguintes palavras:

O mundo só existe para o homem em virtude da atividade do homem: é a
subjetividade transcendental que constitui o mundo como mundo-objeto.
Com isto Kant pretende superar o que chamou de dogmatismo da
metafísica: o sujeito é o elemento decisivo no conhecimento e na ação
humanos, pois é o elemento de determinação do processo. Sem a ação da
subjetividade, o conhecimento e a ação são impensáveis e por isso querer
tematizá-los sem levantar a pergunta transcendental é cair no mais
profundo dogmatismo ${ }^{297}$.

A filosofia de Kant se define, então, como uma filosofia da subjetividade, entendida como uma filosofia do conhecimento. Sua intuição representou o que os intérpretes denominam "revolução copernicana" na filosofia moderna, inaugurando o advento de um novo paradigma de racionalidade, o paradigma subjetal. $\mathrm{O}$ aspecto fundamental para a atividade de conhecer não é a coisa-em-si, mas a relação que se desenvolve entre o objeto e a subjetividade que o apreende. O sujeito assume na teoria de Kant um papel ativo, determinante.

Tem-se, com Kant, uma revolução antropologizante do pensamento ocidental. Como esclarece Oliveira em sua tarefa de sistematização, o homem moderno não se entende mais como contemplador passivo no mundo, como como construtor ativo, tanto na ordem do conhecimento, como na ordem da ação ${ }^{298}$, o que pode explicar o advento da ciência moderna e das revoluções políticas liberais. O homem é, para Kant, a medida do mundo. Desse modo, tem-se que, de acordo com o paradigma de racionalidade desenvolvido pela filosofia do pensador alemão:

\footnotetext{
${ }^{296}$ OLIVEIRA, Manfredo. A Filosofia na Crise da Modernidade. São Paulo: Loyola, 2001, pg. 10.

297 OLIVEIRA, Manfredo. Ibidem, pg. 17.

${ }^{298}$ OLIVEIRA, Manfredo. Op. cit.
} 
Para Kant, experiência não é mera recepção de dados, mas sua transformação em objeto para o homem. Com isto, afirma-se que a experiência do mundo é mediada por uma atividade prévia da subjetividade humana. É neste sentido que se pode afirmar que o mundo só existe através do homem: não evidentemente em sua realidade física, mas como objeto do qual falamos e fazemos afirmações ${ }^{299}$.

A filosofia da subjetividade define o processo de conhecimento a partir da perspectiva do sujeito, reconhecendo-se, desde Kant, a impossibilidade de apreensão da coisa em si. A subjetividade, ao "captar" o objeto, o faz através das "lentes" que moldam sua visão sobre o mundo, os sentidos. Tem-se, com isso, a passagem do mundo em si para o mundo para o homem ${ }^{300}$. Volta-se a reflexão filosófica para as condições de possibilidade do ato de conhecer, a partir da demonstração abstrata dos elementos transcendentais da racionalidade. Segundo Oliveira:

\begin{abstract}
Kant chama de transcendental a análise que procura detectar os elementos apriorísticos do conhecimento humano, que não são objetos ao lado dos objetos tratados pelas diversas ciências, mas elementos constitutivos de toda e qualquer objeto, pois toda pergunta pelo objeto pressupõe a pergunta pela possibilidade, no sujeito, do conhecimento do objeto ${ }^{301}$.
\end{abstract}

Uma das grandes contribuições da filosofia kantiana é, portanto, o seu caráter antropocêntrico, responsável pela constituição da noção de sujeito no bojo da sociedade moderna. O eu que conhece é, também, o eu titular de direitos, autor da carta constitucional e contratante do pacto que funda a sociedade política a partir do acordo de vontades livres.

O advento da revolução industrial e a crescente complexidade da sociedade ocidental foram alguns dos fatores responsáveis pelo reconhecimento da insuficiência do paradigma filosófico da subjetividade. A virada para o século XIX trouxe, com a análise marxista e o historicismo alemão, a compreensão do caráter mutável do homem, de sua dependência aos fatores externos no processo de constituição da racionalidade.

O paradigma kantiano, apesar de revolucionário em diversos aspectos, também se mostrou insuficiente em sua tarefa de explicar o processo de conhecimento, na medida em que não deu conta de considerar a força da história e o papel das relações humanas no ato de conhecer e dar sentido ao mundo. Desse modo, embora a contribuição kantiana seja fundamental, por reconhecer o papel ativo da subjetividade no ato de conhecer, é preciso ir além de Kant, para perceber que o “eu” que conhece é, também, impregnado de história, de

\footnotetext{
${ }^{299}$ OLIVEIRA, Manfredo. Op. cit.

${ }^{300}$ OLIVEIRA, Manfredo.Op. cit.

${ }^{301}$ OLIVEIRA, Manfredo. Op. cit., pg. 9.
} 
um passado, de um horizonte de significados a partir do qual essa subjetividade vai construir o objeto.

\subsection{O Paradigma da Razão Comunicativa}

A reviravolta linguístico-pragmática implica, portanto, o reconhecimento da insuficiência do modelo de racionalidade construído por Kant, tendo em vista a compreensão do efeito da história sobre a constituição da própria subjetividade. O sujeito, portanto, se define como existência culturalmente condicionada desde a origem. $\mathrm{O}$ condicionamento da subjetividade é evidenciado pela relação do sujeito com os demais indivíduos do grupo que, a partir da transmissão das heranças de significados, definem os conceitos a partir dos quais o homem se expressa e compreende o mundo à sua volta.

O cerne da reflexão filosófica deixa de ser o sujeito e torna-se a linguagem, considerada instância intrascendivel da expressividade do mundo ${ }^{302}$. Para Oliveira, Gadamer parte de Kant para ir além de Kant, na medida em que pretende precisamente mostrar que a constituição do sentido não é obra de uma subjetividade isolada e separada da história, mas só é explicável a partir de nossa pertença à tradição ${ }^{303}$. É preciso reconhecer não só a relação $e u$-mundo, mas a relação entre as subjetividades, a relação $e u$ outro como condicionantes do processo de conhecimento.

O sujeito é, portanto, um ser essencialmente histórico, cuja razão é exercida em função de seus pré-conceitos e pré-compreensões sobre o próprio mundo, os quais se manifestam através do discurso. Desse modo, o sujeito já desde sempre se "experimenta" no seio de um mundo de sentido, ao qual ele pertence e que nunca simplesmente pode tornar-se seu objeto $^{304}$, na medida em que a consciência do sujeito é determinada pela história ${ }^{305}$.

A reviravolta lingüístico-pragmática resultou no reconhecimento da intersubjetividade como elemento indispensável à razão, que passa a ser definida como

\footnotetext{
302 OLIVEIRA, Manfredo. A Reviravolta Linguístico-Pragmática na Filosofia Contemporânea. São Paulo: Loyola, 2006, pg. 13.

${ }^{303}$ OLIVEIRA, Manfredo. Ibidem, pg. 227.

${ }^{304}$ OLIVEIRA, Manfredo. Ibidem, pg. 230.

305 OLIVEIRA, Manfredo. Ibidem, pg. 227
} 
razão discursiva, ou comunicativa. Esse pressuposto teórico-filosófico é essencial às teorias procedimentalistas, que utilizam o diálogo como mecanismo definidor do procedimento de formação das normas éticas, aí incluídas as normas morais e as normas jurídicas. A forma de garantir a validade das normas jurídicas é justamente a definição de condições ideais de diálogo entre os sujeitos, a fim de que as melhores razões prevaleçam no embate discursivo.

A análise de Costa pode ser bastante esclarecedora sobre a descoberta de uma nova forma de pensar a subjetividade e o pensar humano, surgida no século XX a partir do reconhecimento da comunidade da linguagem. São as palavras do autor:

Em nosso século, tem-se compreendido cada vez mais a articulação do
sentido intersubjetivo do pensar e agir humanos e sua validação como
constituída linguisticamente e de tal modo que a problemática da
constituição da racionalidade do sentido e sua validade tem sido
tematizada através de um novo horizonte, o horizonte da linguagem. Este
horizonte tem como implicação que já não se pode mais tematizar o
sentido racional da existência e atividades humanas sem a mediação do
uso comunicativo da linguagem, ou seja, a partir de tal horizonte de
compreensão, a razão articuladora e portadora de sentido não poder ser
entendida a não ser como razão comunicativa e intersubjetiva ${ }^{306}$.

A razão é entendida, portanto, como linguagem, que, por sua vez, significa interação. Assim como não há a coisa-em-si como um objeto acessível ao sujeito, tal qual Kant esclareceu, também não há a coisa-para-o-eu, como uma racionalidade isolada, que pode conhecer o mundo independentemente do outro. O mundo, como uma totalidade de sentido, existe para a comunidade de sujeitos que, compartilhando os seus significados, lhe dão ordem, numa tarefa “articuladora”, para usar a expressão de Costa.

Essa transformação do paradigma da racionalidade empreendida pela filosofia ocidental não é alheia à teoria do direito. Também a ordem jurídica é entendida como uma construção mediada pela linguagem. Não só a norma é originada de um embate discursivo internalizado pelo poder legislativo, como a decisão sobre o "justo", o "correto", o "conforme" é tomada no âmbito de uma interação comunicativa simbolizada pelo processo. Por esse motivo, o ato de criar o direito não pode ser um ato de exclusão, mas um processo que reconheça a existência de tantos argumentos quanto são os potenciais argumentantes.

\footnotetext{
${ }^{306}$ COSTA, Regenaldo da. Ética do Discurso e Verdade em Apel. Belo Horizonte: Del Rey, 2002, pg. 4.
} 
O processo, tomado em sentido amplo - legislativo, judicial, administrativo -, existe como meio para que se alcance a melhor razão, o melhor argumento nos conflitos acerca da interpretação das normas. Trata-se, assim, de uma organização em procedimento fundada na ideia comunicação. Em outros termos, a institucionalização da razão comunicativa no âmbito do estado pela ação do Direito.

Sendo o direito afetado pela reviravolta da linguagem, redescobre-se o problema da fundamentação normativa. O direito, para ser legítimo, precisa ser justificado. Buscando estabelecer uma relação entre a reviravolta linguística e a transformação epistemológica do direito, Duarte reconhece que o discurso de fundamentação é condicionado pela razão dialógica, ou comunicativa. Segundo o autor:

\begin{abstract}
A tentativa de oferecer pautas justificativas que assegurem a racionalidade do método jurídico visando à busca de critérios objetivos para o controle das opções prático-morais incrustradas na formulação das decisões jurídicas deve se dar conta de que a fundamentação normativa do Direito, hoje, deve ser mediada desde os pressupostos discursivos inseridos na estrutura pragmática consolidada a partir de uma razão linguística ${ }^{307}$.
\end{abstract}

Para o autor, um paradigma da racionalidade discursiva terá necessidade de construir uma nova Teoria do Direito ${ }^{308}$. A transformação mencionada por Duarte passa necessariamente por uma nova compreensão da dinâmica jurídica possibilitada pela flexibilização das estruturas normativas tradicionais. O reconhecimento da força normativa dos princípios traz para a teoria do direito a necessidade de adaptar a hermenêutica jurídica à baixa densidade normativa dos comandos principiológicos. A consequência fundamental é o reconhecimento de que o intérprete, diante da necessidade de ponderação de valores, possui uma razoável liberdade de criação argumentativa.

Em verdade, o reconhecimento da existência de normas com estrutura de princípios, caracterizadas pela sua baixa densidade normativa e pela aplicação da técnica da ponderação, sinaliza a necessidade de que o direito seja suficientemente plástico, flexível, para dar conta da pluralidade de pretensões, valores, condutas e eticidades existentes no corpo social. A constituição, assim, para fazer frente à diversidade, precisa ser ela mesma aberta, inclusiva, "principiológica".

${ }^{307}$ DUARTE, Écio Oto Ramos. Teoria do Discurso e Correção Normativa do Direito: Aproximação à Metodologia Discursiva do Direito, $2^{\mathrm{a}}$ ed. São Paulo: Landy, 2010, pg. 35.

${ }^{308}$ DUARTE, E. O. R. Ibidem, pg. 38. 
O modelo de racionalidade dialógica estabelecido pela reviravolta linguísticopragmática tem indiscutível relação com a institucionalização da democracia, segundo esclarece Blotta:

O modelo procedimental de democracia seria, portanto, uma procedimentalização e institucionalização de processos argumentativos de formação da opinião e da vontade públicas, cujo conteúdo normativo reside nos meios (procedimentos) com os quais um consenso mais livre possível pudesse ser estabelecido, i.e., na efetiva observação dos próprios pressupostos pragmáticos do agir comunicativo. Ou seja, a maneira de se avaliar a qualidade da democracia estaria na forma com que ela institucionaliza os conteúdos do sistema de direitos; em outras palavras, na análise de seu nível de discursividade ${ }^{309}$.

É através dos procedimentos de deliberação democrática, portanto, que o diálogo pode ganhar espaço enquanto meio fundamental de construção dos comandos. A democracia, assim, tem a função de garantir a validade dos conteúdos normativos, legitimando-os. Isso porque somente os comandos impostos democraticamente teriam passado pelas provas racionais próprias do discurso de fundamentação.

A transformação dos paradigmas filosóficos resultante da reviravolta linguísticopragmática foi acompanhada por uma mudança nos modelos liberal e social de estado de direito ao longo do século XX. A rigidez da democracia representativa liberal e o fortíssimo intervencionismo estatal do nacional socialismo não foram capazes de evitar a ocorrência da catástrofe da segunda guerra e a ascensão dos modelos totalitários que nela alcançaram o seu ápice.

Resgata-se, com o advento da Lei Fundamental de Bonn e das constituições italiana e hispânica, principalmente, a necessidade de controles mais rígidos da ação estatal, ao mesmo tempo em que estejam garantidos os direitos fundamentais individuais e sociais. $\mathrm{O}$ modelo de estado de direito moderno passa por uma ressignificação a fím de incorporar a democracia como forma básica de organização do poder, simbolizada pelo direito à participação. Desse modo, é importante compreender, conforme esclarece Fred Dallmayr, que a democracia não é apenas uma opção de regime dentro outras igualmente

\footnotetext{
${ }^{309}$ BLOTTA, Vitor S. L. Habermas e o Direito: Da Normatividade da Razão à Normatividade Jurídica. São Paulo: Quartier Latin, 2010, pg. 316.
} 
disponíveis em todos os momentos e lugares, mas mais propriamente constitui uma resposta a desafios e aspirações históricos ${ }^{310}$.

A democratização das principais repúblicas europeias e, mais tardiamente, das repúblicas latino-americanas, foi acompanhada pela crescente especificação e positivação no âmbito internacional - dos direitos humanos fundamentais. Esse contexto acabou por fortalecer a esfera pública, gerando um anseio crescente por formas de participação - tidas como meios de exercício direto da soberania. Segundo Oliveira, Os direitos humanos e a democracia se estabeleceram, historicamente, como condições necessárias para a emergência de diferentes opiniões e foros pluralistas de discussão pública ${ }^{311}$. Tem-se, nesse sentido, uma institucionalização da razão comunicativa vislumbrada pela reviravolta linguística de meados do século XX.

Para Guerra Filho, o advento do estado democrático de direito possibilita uma rearticulação entre direito e política, através da "procedimentalização" do direito:

\begin{abstract}
A fundamentação moral e política dos princípios jurídicos, isto é, a legitimidade do Direito, e a sua "procedimentalização", acham-se intimamente relacionados, já que os valores legitimadores do mesmo não se encontrariam propriamente no conteúdo de suas normas, mas sim nos procedimentos, que fundamental algum de seus possíveis conteúdos ${ }^{312}$.
\end{abstract}

A noção de procedimentalização mencionada por Guerra Filho é o foco das teorias normativas sobre a democracia deliberativa, com ênfase nos estudos promovidos pelo alemão Jürgen Habermas. O sociólogo estabelece uma revisão da democracia representativa, propondo um modelo de democracia baseado na radicalização da soberania popular e na noção de autodeterminação política ${ }^{313}$.

Para Habermas, o exercício do poder político só pode ser justificado com base no uso público da razão ${ }^{314}$, motivo pelo qual se relaciona a reviravolta linguístico-pragmática - com sua nova compreensão de racionalidade - e o desenvolvimento do modelo democrático contemporâneo. Assim sendo, no campo social e, notadamente, na esfera

\footnotetext{
${ }^{310}$ DALLMAYR, Fred. Para além da democracia fugidia: Algumas Reflexões Modernas e Pós-Modernas. In: SOUSA, Jessé. Democracia Hoje: Novos desafios para a teoria democrática contemporânea. Brasília: Editora UnB, pg. 13.

311 OLIVEIRA, Nythamar de. O Problema da Fundamentação Filosófica dos Direitos Humanos: Por um Cosmolitismo Semântico-Transcendental. In: Ética, Florianópolis, v. 5, n.1, pg. 21-31, jun. 2006.

${ }^{312}$ GUERRA FILHO, Willis. Op. cit., pg. 20.

${ }^{313}$ VITALE, Denise V.; MELO, R. S. Política Deliberativa e Modelo Procedimental de Democracia. In: NOBRE, Marcos; TERRA, Ricardo. Direito e Democracia: Um guia para leitura de Habermas. São Paulo: Malheiros, 2008, pg. 224.

${ }^{314}$ VITALE, Denise V.; MELO, R. S. Ibidem, pg. 227.
} 
jurídico-política, o trabalho da razão é inseparável de uma intersubjetividade que, no essencial, é mediatizada pela linguagem e, mais precisamente, pela prática da discussão ${ }^{315}$.

Bittar esclarece que, no pensamento de Habermas, moral, direito e política exercem funções específicas e autônomas, embora complementares ${ }^{316}$. Por esse motivo, o referencial teórico habermasiano, em especial sua teoria sobre o direito e sobre os direitos fundamentais, pode ser especialmente útil para a análise do sentido, dos limites e da importância do poder constituinte no ambiente democrático.

\subsection{Razão Comunicativa e as Alternativas à Teoria do Poder Constituinte}

Seguindo o percurso argumentativo desta tese, tem-se que, até este ponto, foram apresentados os principais postulados da teoria clássica do poder constituinte, inclusive quanto às suas releituras e insuficiências. A teoria clássica foi construída à luz do modelo de estado liberal, para o qual o direito exerce uma função social marcante: a garantia do espaço de liberdade individual em face do poder estatal, historicamente associado ao excesso do absolutismo.

De acordo com esse raciocínio, enquanto que, no estado pré-moderno, o direito se subordina ao poder para cristalizar uma rígida hierarquização social deduzida da vontade divina, no estado moderno, o direito assume a função de conduzir o próprio exercício do poder: o estado é criado e delimitado à luz do direito, sendo as normas legais produzidas no bojo de um processo legislativo marcado pela representação. O poder constituinte moderno, por assim dizer, é a representação de um "anseio de legitimação" dirigido ao modelo de organização política nascido de um processo revolucionário e que se insurge contra a ordem jurídica estabelecida.

Habermas esclarece esse papel ambivalente do Direito, percebido na passagem do estado pré-moderno para o estado moderno:

\footnotetext{
315 GOYARD-FABRE, Simone. Princípios Filosóficos do Direito Político Moderno. São Paulo: Martins Fontes, 1999, 482.

${ }^{316}$ BITTAR, Eduardo C. B. Justiça e Emancipação: Reflexões Jusfilosóficas a partir do Pensamento de Jürgen Habermas. São Paulo: USP, 2011, pg. 493.
} 
O "acoplamento" entre direito e política é tão antigo quanto o próprio Estado. Por essa razão, o direito exerceu por séculos um papel ambivalente: serviu como meio de organização para a dominação política exercida autoritariamente e foi ao mesmo tempo uma fonte de legitimação indispensável para as dinastias dominantes. [...] Com certeza, o poder do Estado teve de ser secularizado e o direito ser plenamente positivado antes que a legitimação da dominação pudesse se tornar dependente de um consentimento juridicamente institucionalizado por parte daqueles subordinados à própria dominação ${ }^{317}$.

Compreende-se, assim, na Modernidade, a elaboração da constituição como o momento simbólico de passagem de uma ordem marcada pelo absolutismo para uma ordem garantidora das liberdades burguesas. O poder constituinte, sendo a potência criadora do texto a ser positivado, é o momento temporal e o espaço político em que todas as expectativas normativas e os valores são canalizados para o médium do direito.

Esse processo de "juridificação", como esclarece Habermas, que se inicia com o advento da constituição e que é perpetuado pela legislação ordinária, desencadeou não somente uma força racionalizadora, mas também civilizadora, na medida em que dirimiu o caráter autoritário do poder $^{318}$. Esta a principal função do poder constituinte da revolução liberal: permitir o advento concreto de uma nova ordem jurídica, marcada pela ideologia burguesa.

Para concretizar esse objetivo - a completa subversão do estado absoluto - era necessário conceber um poder constituinte com características marcantes: ilimitado, originário, insuscetível de qualquer condicionamento prévio. A identificação do sujeito constituinte, o titular do poder, não se mostrou clara: o poder é do povo, mas não o povo em sua realidade histórica e objetiva, o povo simbolizado na figura do representante.

Essa arquitetura teórica liberal não se mostra satisfatória para o exercício do poder constituinte hoje. A modernidade do Direito e da filosofia política passou por uma considerável remodelação no pós-segunda guerra mundial: o estado de direito em sua manifestação clássica não foi capaz de garantir a liberdade ou mesmo impedir a catástrofe da guerra, necessário, então, transformar esse estado em uma ordem democrática e inclusiva. Surge, portanto, a noção de um estado democrático de direito.

\footnotetext{
317 HABERMAS, Jürgen. A crise da União Europeia à luz de uma constitucionalização do direito das gentes: Um ensaio sobre a constituição da Europa. In: HABERMAS, Jürgen. Sobre a Constituição da Europa, traduzido por Denilson Werle, Luiz Repa e Rúrion Melo. São Paulo: Editora Unesp, 2012, pgs. 4546.

${ }^{318}$ HABERMAS, Jürgen. Ibidem, pg. 46.
} 
Perelman indica a mudança no raciocínio judiciário e nas concepções de direito após a segunda guerra como uma reação ao positivismo jurídico e sua incapacidade de dar conta da conflituosidade social, por excesso de rigidez normativa. A ordem abstrata e racional pensada pela escola da exegese e seus teóricos não condiz com uma realidade marcada pela diferença cultural e pela desigualdade econômica. Pensado à luz do método empregado nas ciências naturais, o direito do positivismo tornou-se um dado "puro", na medida em que foi considerado o objeto normativo independentemente de qualquer relação com os questionamentos relativos à justiça ${ }^{319}$.

O positivismo liberal representou, portanto, um déficit de fundamentação no Direito indicado como um dos responsáveis pelo advento das ordens totalitárias do nacionalsocialismo. Mostrou-se indispensável, assim, resgatar o argumento pela necessidade de um fundamento moral para a ordem jurídica, capaz de orientar axiologicamente o sistema de normas. O dogma do fechamento operativo do Direito não pôde excluir a necessidade de uma referência moral.

Neste ponto, um problema se põe: como superar o esgotamento moral do positivismo sem recorrer às teses do direito natural e sua referência a um ideal de justiça abstrato, atemporal, universal e, também, irreal em uma sociedade complexa e multifacetada? O discurso pela superação do positivismo não implica, portanto, a retomada do Direito natural, o que seria insustentável depois de Kant e sua contribuição filosófica.

Isso porque as mudanças observadas no cenário político dos estados nacionais e na ordem internacional refletem não só uma tensão no âmbito social, mas são representativas de uma mudança no próprio paradigma filosófico da Modernidade. Por esse motivo, a título de pressuposto, foi necessário apresentar a virada linguística que implicou o surgimento de uma nova ideia de racionalidade.

A descoberta da importância da linguagem e a definição do processo cognitivo como uma interação discursiva trouxe um argumento de peso em favor da democracia. A organização democrática é preferível por sua força civilizadora, por tornar possível uma reaproximação da moral e do direito: pela democracia são criados canais de diálogo e de inclusão que permitem uma troca construtiva entre as eticidades. Ao submeter a validade

\footnotetext{
${ }^{319}$ PERELMAN, Chaïm. Lógica Jurídica: Nova Retórica, tradução de Vergínia Pupl. São Paulo: Martins Fontes, 1998, pg. 91.
} 
do direito ao assentimento racional, a racionalidade comunicativa permite a redescoberta de toda a "carga moral" antes atribuída ao direito natural ${ }^{320}$.

O poder constituinte democrático precisa ser capaz de introduzir esses canais de diálogo dentro da estrutura do estado, a partir da preservação de determinados pressupostos fundamentais, como o direito à participação política. Como, então, essas novas exigências que surgem para a teoria do poder constituinte podem ser superadas, levando-se em conta a teoria da democracia? De que modo a mudança operada pela reviravolta da linguagem pode determinar, também, uma mudança na teoria do direito constitucional?

Para responder a essas indagações e propor uma percepção sobre o poder constituinte para além dos postulados da teoria clássica, utiliza-se, dentre várias leituras disponíveis, a teoria de Jürgen Habermas sobre a democracia e sua relação com o discurso de fundamentação do direito.

A proposta habermasiana, que pode ser definida como uma abordagem procedimentalista, associa: a) uma determinada intepretação sobre o desenvolvimento e os processos de diferenciação da sociedade moderna; $b$ ) uma teoria sobre o agir comunicativo e a validade das normas éticas; c) uma teoria sobre a democracia assentada na ideia de consenso e de diálogo e d) uma teoria sobre o direito e, sobretudo, sobre os direitos fundamentais e sua relação com a moralidade. A sua filosofia, assim, se propõe a fornecer uma orientação para a práxis, a fim de que a negociação política de objetivos e programas se dê a partir de um determinado conceito de justiça ${ }^{321}$.

Parece evidente que qualquer teoria sobre o estado contemporâneo não pode deixar de levar em consideração o consenso como fundamento de legitimidade básico, o que remete diretamente ao procedimentalismo. Honneth, apesar de considerar insatisfatório o modelo procedimentalista puro, afirma ser hoje um "consenso abrangente" entre as teorias da justiça um esquema procedimentalista fundamental, a ideia da justiça distributiva e uma certa fixação no estado em conjunto ${ }^{322}$.

A leitura de Habermas sobre a modernidade e a democracia pode auxiliar, na qualidade de teoria procedimentalista, a construção de uma teoria sobre o poder

\footnotetext{
${ }^{320}$ HABERMAS, Jürgen. Ibidem, pg. 45.

${ }^{321}$ HONNETH, Axel. A textura da justiça: sobre os limites do procedimentalismo contemporâneo, tradução de Emil Sobottka e Joana Ripoll. In: Civitas, Porto Alegre, v.9, n. 3, set.-dez./2009, pg. 346.

${ }^{322}$ HONNETH, Axel. Ibidem, pg. 347.
} 
constituinte adequada à nova ideia de justiça. Explicando referido consenso teórico sobre o procedimentalismo, Honneth esclarece a importância do assentimento na formação da vontade pública:

Tanto a justificação como a determinação conteudística da justiça devem resultar da ideia geral de que os princípios de justiça sejam expressão da vontade comum de todas as cidadãs e de todos os cidadãos de assegurarem-se reciprocamente as mesmas liberdades subjetivas de ação $^{323}$.

$\mathrm{O}$ argumento de Honneth é especialmente importante para se constatar que o objetivo fundamental perseguido pelas revoluções liberais na Modernidade - a garantia da autonomia pessoal - só é realizável quando essa liberdade é concebida como resultado de uma formação comum da vontade, tal como ela só acontece na cooperação entre sujeitos $^{324}$. O indivíduo que deseja preservar sua liberdade necessita garanti-la através da participação na vida pública, possível por meio da organização democrática. É por isso que, não se podendo renunciar ao primado da autonomia individual, igualmente não é possível renunciar à democracia como modelo político.

O estado de direito liberal, para dar conta da preservação da autonomia, precisou ir além dela, garantindo também a igualdade material entre os cidadãos, transformando-se em estado do bem-estar à luz de uma orientação de justiça eminentemente distributiva (ou paradigma da distribuição, na definição de Honneth). O conceito de autonomia pessoal é "reduzido" por essa exigência:

[...] Aqui, pois, surge a ideia transcendente de que a criação de relações sociais justas deva servir primeiramente à finalidade de possibilitar a todos os sujeitos igualmente uma forma de autodeterminação que os permita ser tão independentes de ser parceiros de interação quanto possível $^{325}$.

Essa compreensão de justiça e de Direito acabou por provocar uma quase total identidade entre ordem jurídica e ordem estatal. Como esclarece Honneth, tem-se a percepção de que é no âmbito do estado que se pode efetivar a justiça, na medida em que somente ele dispõe dos meios legítimos para impor efetivamente as medidas necessárias para a redistribuição dentro das diversas instituições básicas da sociedade ${ }^{326}$. Mas como a consolidação do estado de direito originado da filosofia do liberalismo implicou em uma exigência pela democracia?

\footnotetext{
${ }^{323}$ HONNETH, Axel. Ibidem, pg. 348.

${ }^{324}$ HONNETH, Axel. Ibidem, pg. 348.

${ }^{325}$ HONNETH, Axel. Ibidem, pg. 349.

${ }^{326}$ HONNETH, Axel. Ibidem, pg. 351.
} 
O indivíduo interessado em preservar o seu espaço de autonomia individual precisa participar ativamente na vida pública. É na esfera de deliberação estatal que as decisões fundamentais sobre a distribuição da riqueza e sobre a garantia das liberdades básicas do indivíduo e do grupo são tomadas, demandando do indivíduo sua transformação em “cidadão", conceito que traz, em si, a noção de participante comprometido.

Considerando que é responsabilidade de cada cidadão e de cada cidadã participar do processo de deliberação acerca da distribuição dos bens e da condução do projeto de sociedade do bem-estar, é indispensável que se apresente o caminho desse procedimento que conduz à justiça distributiva e à autonomia. A teoria não é capaz de fixar os princípios de justiça em si mesmos, pois tal tarefa é atribuída ao corpo de indivíduos organizados, mas pode indicar o procedimento por meio do qual se pode alcançá-los, sendo fundamental, portanto, a definição dos pressupostos e condições que garantam a permanência do próprio procedimento.

Neste ponto é que a discussão sobre o poder constituinte e sobre a estruturação da ordem jurídica ganha relevância. Demonstrar como o poder constituinte pode ser conduzido de modo a facilitar a positivação dos procedimentos democráticos é um dos objetivos específicos do trabalho. A ideia fundamental - uma releitura sobre o poder constituinte - precisou partir da constatação de que os postulados clássicos são insuficientes. Uma nova proposta é possível à luz da mudança operada pela reviravolta linguística.

Dentre as diversas propostas filosóficas, Habermas parece ter uma contribuição especial, pois se preocupa com o resgate moral do Direito sem pretender, com isso, uma recuperação do Direito Natural ou de fundamentos axiológicos inteiramente externos à própria ordem jurídica. Na medida em que, para Habermas, uma norma se fundamenta com base no assentimento racional dos participantes do discurso democrático, a justificação se apresenta como resultado de um processo que, embora não esteja inteiramente delimitado pelo sistema de normas, depende dele, pois a deliberação democrática se dá a partir de procedimentos estruturados com base no direito positivo.

Existem, portanto, condições de participação e de inclusão, normas de organização e garantias, que necessitam estar estruturadas na esfera pública a fim de permitir que o consenso normativo seja alcançado pelos participantes do discurso. Tratam-se de 
procedimentos, instituições e garantias que são fundantes da própria ideia de estado democrático de direito no sentido moderno.

Os dois capítulos seguintes (IV e V) serão dedicados à apresentação da proposta habermasiana e à demonstração de sua relevância para o argumento em favor da teoria do poder constituinte democrático. No capítulo IV, analisa-se o panorama filosófico específico no qual a teoria habermasiana se insere, notadamente no que tange às discussões da teoria do discurso sobre a crítica da racionalidade instrumental e sobre possibilidade de uma fundamentação universal para a moral e para o direito. No capítulo $\mathrm{V}$, dá-se enfoque à teoria habermasiana sobre o Direito e os direitos humanos e sua correlação com a teoria da democracia, apresentada de forma geral na obra Direito e Democracia: Entre Facticidade e Validade (Faktizität und Geltung. Beiträge zur Diskurstheorie des Rechts und des demokratische Reichstaats). 


\section{A FUNDAMENTAÇÃO DA ÉTICA PELO DISCURSO E O MODELO PROCEDIMENTAL DE DEMOCRACIA}

Este trabalho busca desenvolver uma proposta de poder constituinte cujo exercício importe na criação de um direito racionalmente justificado e, portanto, legítimo. Segundo o raciocínio que se desenvolve, há uma necessária associação entre o processo de criação constitucional desde a Modernidade e o modelo democrático de organização política.

No capítulo anterior, o objetivo foi apresentar a reviravolta linguístico-pragmática como o mais relevante pressuposto filosófico da associação democracia-legitimidade, na medida em que a mudança no paradigma da racionalidade teve como consequência o surgimento de uma compreensão dialogal de razão, levando ao reconhecimento da dignidade dos sujeitos como participantes de discursos racionais.

A transformação do paradigma filosófico da modernidade ocasionou $o$ reconhecimento do valor transcendental de posição da linguagem e, com isso, da comunidade linguística ${ }^{327}$. Não mais o sujeito do conhecimento, mas a comunidade de sujeitos é a responsável pela construção das asserções sobre o mundo e o conceito de validade passa por uma remodelação baseada na noção de diálogo, como demonstrado.

A questão importa à teoria jurídica, na medida em que o sujeito de direitos, assim com o sujeito do conhecimento, está também inserido em um corpo de indivíduos que pressupõem mutuamente sua condição de iguais para que a liberdade de cada um seja assegurada em relação aos demais, como já definido por Kant. A solidariedade social, portanto, é a condição que assegura o status de liberdade individual, basilar na compreensão moderna de sociabilidade. Embora se possa argumentar que a contribuição kantiana estivesse baseada em paradigma de racionalidade ainda fundado na ideia de sujeito - e não na perspectiva da linguagem - é preciso reconhecer, com Habermas, que com sua noção de autonomia, o próprio Kant já introduz um conceito que só pode

\footnotetext{
327 APEL, K. O. Estudos de Moral Moderna, tradução de Benno Dischinger. Petrópolis: Vozes, 1994, pg.
} 15. 
explicitar-se plenamente dentro de uma estrutura intersubjetivista ${ }^{328}$, posto que pressupõe a importância do outro no reconhecimento do espaço intangível de liberdade do indivíduo.

É preciso demonstrar, portanto, como um direito que se pretende legítimo - isto é, capaz de consagrar a liberdade individual a partir da solidariedade social - pode ser institucionalizado. Neste ponto, tem-se a intuição de uma complementaridade entre positivação do direito e a política.

Para uma explicação de como a democracia sintetiza o modelo que institucionaliza a razão comunicativa e que oferece as condições para a circulação do poder em sociedades complexas orientadas para a legitimidade e para a liberdade ${ }^{329}$, optou-se pelo referencial teórico desenvolvido pelo sociólogo alemão Jürgen Habermas. Neste capítulo, pretende-se apresentar de que modo as elaborações teóricas desenvolvidas pelo autor podem ser úteis para a análise sobre o exercício e os condicionamentos do poder constituinte no sentido de uma fundamentação racional do Direito.

Não é o objetivo deste trabalho propor uma exaustiva revisão da obra filosófica do autor alemão, sob pena de perda de foco e objetividade. A fim de justificar a utilização do seu referencial teórico, propõe-se, neste capítulo, em síntese, apresentar o panorama da ética do discurso e suas questões fundamentais, em especial a análise da possibilidade de uma fundamentação racional para a ética. É justamente a demonstração de que é possível, a partir de um novo modelo de racionalidade, justificar racionalmente comandos éticos que torna sólida a teoria habermasiana sobre a democracia e sua relação com o direito positivo.

\subsection{Da Possibilidade de uma Fundamentação Racional para as Normas do Agir Humano: A Ética do Discurso}

O movimento filosófico intitulado "Ética do Discurso", da qual fazem parte nomes como o de Habermas e Apel, tem sua unidade no conjunto de elaborações e análises teóricas voltadas ao estudo do agir humano orientado para o bem, tendo por referencial

\footnotetext{
${ }^{328}$ HABERMAS, J. A Ética da Discussão e a Questão da Verdade, tradução de Marcelo Cipolla. São Paulo: Martins Fontes, 2007, pg. 13.

329 HABERMAS, J. Direito e Democracia: entre facticidade e validade, v. I, tradução de Flávio Siebeneichler. Rio de Janeiro: Tempo Brasileiro, $2^{\mathrm{a}}$ ed., 2012, pg. 10.
} 
fundamental a reviravolta linguístico-pragmática e a consolidação do paradigma da racionalidade dialogal. De acordo com a ética do discurso, as normas éticas adquirem sua validade universal (e, consequentemente, sua exigibilidade) a partir do procedimento discursivo, no qual as razões serão testadas pelos sujeitos em diálogo, na busca de um consenso. Não se trata, portanto, de uma ética de conteúdo - norma nenhuma é boa $a$ priori, por si mesma - mas uma ética procedimental, para qual a norma é considerada "boa" se resultante de um acordo racional entre sujeitos livres e autônomos.

A ética do discurso surge no século XX, como consequência do desenvolvimento dos estudos em filosofia da linguagem. A descoberta de um novo paradigma de racionalidade, a razão dialógica, é o pressuposto mais importante dos autores representantes desse movimento. Esclarece Cortina:

\begin{abstract}
A ética discursiva foi se configurando a partir dos anos 1970 como um dos raios do denso núcleo filosófico constituído pela pragmática formal (transcendental ou universal), a teoria da ação comunicativa, uma nova teoria da racionalidade, uma teoria consensual da verdade e da correção e uma teoria da evolução social ${ }^{330}$.
\end{abstract}

De acordo com a autora, trata-se de uma ética no sentido forte, que não acredita no fracasso do projeto moral iluminista. Seu caráter procedimental é evidente, pois sabe que não the cabe prescrever formas concretas de vida, ideais de felicidade, modelos comunitários - inclusive nacionais - de virtude, e sim proporcionar os procedimentos que permitam legitimar normas e, portanto, prescrevê-las com uma validade universal ${ }^{331}$.

É possível reconhecer a existência de uma íntima relação entre o procedimentalismo da ética discursiva e o consensualismo próprio dos modelos democráticos. Isso porque o princípio da ética discursiva faz a validade de toda norma depender do consenso racional entre os envolvidos por ela, um consenso no qual se demonstra a coincidência entre os interesses individuais e os universais ${ }^{332}$. A norma ética nasce, portanto, de uma esfera pública organizada de forma participativa e inclusiva na qual o consenso racional deve ser buscado pelos sujeitos participantes do discurso.

Desse modo, a ética do discurso é condição de possibilidade e validade da formação de um consenso racional legítimo, portanto, da constituição intersubjetiva da

\footnotetext{
${ }^{330}$ CORTINA, Adela. Ética sem moral, tradução de Marcos Marcionilo. São Paulo: Martins Fontes, 2010, pg. 163.

${ }_{331}^{331}$ CORTINA, Adela. Ibidem, pg. 164.

332 CORTINA, Adela. Ibidem, pg. 166.
} 
verdade ${ }^{333}$. Essa compreensão ética busca, assim, um princípio de justiça universalmente válido enquanto princípio normativo de articulação da organização social ${ }^{334}$. A preocupação com a fundamentação das normas éticas é, portanto, o problema fundamental, tendo em vista o objetivo de reconhecer o status de saber racional à Ética. Para que o consenso racional seja possível,

Pressupõe-se, com isso, o reconhecimento dos outros como sujeitos capazes de verdade, portadores dos mesmos direitos de levantar pretensões de validade e de trazer à discussão bons argumentos, o que, por sua vez, implica o dever recíproco de fazer valer unicamente argumentos e nenhuma instância alheia à argumentação, portanto, a exclusão da violência e a obrigação ética de resolver, pela mediação do diálogo e da argumentação, todas as pretensões de validade da vida histórica em todos os seus níveis ${ }^{335}$.

Tratam-se, portanto, das condições procedimentais para que se alcance a norma fundamentada, isto é, a norma que nasce do consenso racional. Por consenso racional devese compreender não a concordância fática/numérica dos sujeitos, mas o reconhecimento intersubjetivo das razões expostas. A prevalência da melhor razão. Para o êxito de tal procedimento é fundamental: o reconhecimento do direito de participação e a postura receptiva às razões do outro, na qualidade de uma abertura ao entendimento racional. Tratam-se, portanto, de condições ideais de discurso.

Como movimento filosófico, a ética do discurso é consequência do "fim do metafísica", no sentido atribuído por Lebrun ${ }^{336}$, na medida em que busca não a ideia abstrata e universal de bem e de bom, mas as condições necessárias (transcendentais) do próprio pensar, através do qual os sujeitos se inserem no diálogo na apresentação e no julgamento das razões. A questão se desloca da verdade dos enunciados normativos considerados bons para a sua validade, isto é, para as condições através das quais uma norma racionalmente fundamentada é produzida.

Como representante da ética do discurso, tem-se que uma das questões fundamentais para a reflexão filosófica habermasiana é a reabilitação da Moralidade como discurso racional. O problema fundamental é: como, depois de Weber e da razão instrumental própria das ciências naturais, sustentar que as normas orientadoras do agir humano são justificáveis universalmente, sem que se tenha um recurso à metafísica?

\footnotetext{
${ }^{333}$ COSTA, Regenaldo da. Ética do Discurso e Verdade em Apel. Belo Horizonte: Del Rey, 2002, pg. 13.

${ }^{334}$ OLIVEIRA, Manfredo de Araújo. Ética, Direito e Democracia. São Paulo: Paulus, 2010, pg. 25.

${ }^{335}$ OLIVEIRA, Manfredo de Araújo. Ibidem, pg. 25.

${ }^{336}$ LEBRUN, GÉRARD. Kant e o Fim da Metafísica, tradução de Carlos Moura. São Paulo: Martins Fontes, 2002.
} 
No subitem que se segue, analisa-se o sentido de racionalidade instrumental e sua contraposição ao paradigma de racionalidade comunicativa proposto por Habermas, a partir da leitura que este faz da teoria weberiana.

\subsubsection{A Racionalidade Instrumental e a Negação do Fundamento da Ética}

Jessé Souza, em seu texto Patologias da Modernidade, um diálogo entre Habermas e Weber, apresenta uma interpretação interessante para a teoria da racionalidade weberiana e para a crítica de Habermas ao postulado da razão instrumental como único paradigma possível de racionalidade. Habermas, buscando os fundamentos de uma solidariedade póstradicional, confronta as concepções excessivamente instrumentais de racionalidade desenvolvidas por Max Weber e aplicadas à analise da economia e da política, do capitalismo e da burocracia ${ }^{337}$.

Independentemente das críticas apostas por Souza à tese habermasiana sobre a racionalidade comunicativa e sua interpretação sobre a obra de Weber, o texto do autor brasileiro mostra-se útil para a compreensão do sentido de racionalidade instrumental, notadamente no que tange ao desenvolvimento teórico do conceito a partir dos estudos de sociologia da religião empreendidos por Weber. Uma vez que, como se analisará no item seguinte, a ética do discurso e o procedimentalismo democrático de Habermas partem do pressuposto de que a racionalidade instrumental é insuficiente para dar conta de uma orientação moral universal para o agir humano, mostra-se indispensável a compreensão exata do conceito que se tem de racionalidade instrumental no texto de Habermas e em que contexto Weber o utilizou em sua tese, no bojo de sua teoria sobre a sociedade ocidental.

Conforme Souza esclarece, o embate entre Habermas e Weber, considerado o mais modernos entre os clássicos, é peculiarmente elucidativo sobre os desafios lançados para a teoria social tradicional. Isso porque Habermas se propõe a fundar uma teoria que apresente os pressupostos éticos da democracia moderna, com validade universal, quando

\footnotetext{
${ }^{337}$ SOUZA, Jessé. Patologias da Modernidade: Um diálogo entre Habermas e Weber. São Paulo: Anna Blume, 1997, pg. 9.
} 
a tendência dominante associa a política ao mercado, reduzindo-a ao seu aspecto funcional $^{338}$.

De acordo com Souza, para Habermas, a subjetividade libertada das amarras da tradição forma o fundamento da esfera política europeia a partir de 1750, fundamentandose a vida privada segundo um novo patamar de racionalidade. Desse modo:

\begin{abstract}
Não mais simplesmente a violência ou o recurso à tradição são decisivos para A legitimação da ação política. [...] O público literariamente cultivado implica uma igualdade de pessoas cultas, com opinião, igualdade essa indispensável para a legitimação do processo básico da esfera pública: a discussão baseada em argumentos. Pelo lado do público, isso significa o reconhecimento de uma força interna à comunicação, exigindo a desconsideração de fatores sociais externos como privilégios, situação econômica etc. Pelo lado do Estado, esse fato leva à necessidade de justificação da ação política, segundo os mesmos princípios ${ }^{339}$.
\end{abstract}

Para Souza, as questões relativas à teoria de Habermas se põem a partir da constatação de que a esfera pública burguesa organizada discursivamente foi destruída desde o século XIX sob a pressão do aumento da intervenção estatal no universo familiar, a transformação da imprensa em indústria e a formação da indústria cultural. Desse modo, preocupa-se Habermas em pensar uma alternativa para esta sociedade tecnificada e monetarizada que reprime e reduz o espaço da consciência autônoma. Isso porque, como explica Souza, o espaço da liberdade em sentido enfático, ou seja, a escolha segundo normas reflexivas internalizadas nos sujeitos, está ameaçado por instituições que se autonomizaram $^{340}$.

É nesse ponto que a contribuição weberiana para teoria da sociedade é fundamental no percurso argumentativo de Habermas, na medida em que:

Sob o impacto do diagnóstico weberiano da época, que via a razão instrumental embutida na ciência e na técnica dominar todas as esferas da vida social, expulsando os conteúdos de significado e sentido e relegando os dilemas prático-morais a questões técnicas, passa a ser um aspecto essencial da teoria crítica pós-marxista, precisamente a distinção entre emancipação política e progresso técnico ${ }^{341}$.

A crítica ao crescimento unilateral da razão instrumental é, portanto, o porto de partida para a tese da racionalidade comunicativa, como paradigma de razão específico $a o$

\footnotetext{
${ }^{338}$ SOUZA, Jessé. Ibidem, pg. 13.

${ }^{339}$ SOUZA, Jessé. Ibidem, pg. 15.

${ }^{340}$ SOUZA, Jessé. Ibidem, pg. 16.

${ }^{341}$ SOUZA, Jessé. Ibidem, pg. 17.
} 
mundo moderno e desencantado ${ }^{342}$. Compreender o aporte teórico desenvolvido por Weber é, portanto, um caminho necessário à interpretação de Habermas, pois:

Na fundamentação do seu ponto de partida comunicativo utiliza-se
Habermas de Max Weber como um "interlocutor privilegiado", na medida
em que ele - bem no sentido da antiga Escola de Frankfurt - interpreta
Weber como teórico da racionalidade instrumental por excelência, a qual
representa o paradigma de racionalidade que Habermas pretende -
parcialmente - criticar $^{343}$.

Mas o que se entende, então, por racionalidade instrumental? Weber apresenta sua teoria da sociedade ocidental a partir da análise do desenvolvimento da sociedade tradicional à sociedade moderna com o escopo de possibilitar a percepção da ambivalência específica do racionalismo ocidental ${ }^{344}$. Trata-se, portanto, de uma genealogia do processo de desenvolvimento social.

Com os seus estudos sobre a sociologia da religião, Weber explica o triunfo do chamado racionalismo da dominação do mundo, derivado do advento do modelo de economia capitalista. Influindo não apenas no mundo do trabalho ou na economia, a sociedade no capitalismo convive com um processo de reificação da vida em geral. Conforme explica Souza, trata-se aqui, no sentido forte do termo, de uma "recriação" do mundo na medida em que uma nova "racionalidade", especificamente ocidental como iremos ver, passa a permear todas as esferas de atividade humana ${ }^{345}$.

Relacionando o processo de reificação com a religião, Weber entende que o postulado da não-fraternidade no caminho da salvação do protestantismo ascético contribuiu de forma determinante para a dominação da impessoalidade, de modo que as relações intersubjetivas deixam de ter sua característica emocional. A "atitude instrumental" a que se refere Souza não é restrita ao relacionamento do homem com as coisas, mas também consigo, com os outros, e com a natureza, no sentido mesmo de uma razão de dominação ${ }^{346}$.

A desintegração dos vínculos de solidariedade motivada pelo modelo de organização capitalista acaba por justificar o surgimento de um individualismo ético,

\footnotetext{
${ }^{342}$ SOUZA, Jessé. Ibidem, pg. 19.

${ }^{343}$ SOUZA, Jessé. Ibidem, pg. 20.

${ }^{344}$ SOUZA, Jessé. Ibidem, pg. 51.

${ }^{345}$ SOUZA, Jessé. Ibidem, pg. 65.

${ }^{346}$ SOUZA, Jessé. Ibidem, pg. 67.
} 
também provocado pelo processo de "desencantamento" do mundo e pelo colapso dos códigos morais tradicionais. Explica Souza:

Com a reificação do mundo, como consequência do processo de desencantamento ou "desmagificação" (Entzauberung), temos a perda da capacidade de convencimento das éticas materiais de fundo religioso e o aparecimento das pré-condições indispensáveis para o individualismo ético. A transição para o individualismo ético fundamenta, inclusive, a forma peculiar de autoconsciência ocidental e, com isso, o significado específico de seu desenvolvimento cultural, cujo aparecimento deve-se decisivamente, entre outros fatores, ao poder reificador da mensagem protestante ${ }^{347}$.

A consequência fundamental desse processo é o reconhecimento da inexistência de um paradigma de moralidade comum ao grupo. O paradigma da racionalidade instrumental, que orienta a ação para o atendimento de fins, motivou, para Habermas, a perda progressiva da liberdade, reduzindo-se os espaços de ação individual. Isso porque as relações sociais perdem cada vez mais, seja no mundo do trabalho, nas relações de poder ou nas esferas da cultura, o conteúdo ético que possuíam no mundo tradicional ${ }^{348}$.

White também explica o que se deve entender por racionalidade instrumental. De acordo com o intérprete, para os teóricos da escolha racional, os agentes racionais são motivados pelo auto-interesse, isto é, são egoístas maximizadores da utilidade. Inexiste, portanto, uma preocupação solidária com os fins a serem perseguidos, na medida em que a escolha é individual, estrategicamente tomada para maximizar os resultados para o próprio indivíduo. Nesse sentido, a única coisa que não é permitida, para os teóricos da escolha racional, é o uso do conceito de racionalidade para fazer juízos normativos a respeito dos tipos de fins perseguidos ou a motivação que estimula a ação ${ }^{349}$. A citação de White é bastante esclarecedora:

Em senso estrito, tal teoria nem endossa nem recomenda nenhuma posição ou atitude morais. Em particular, não recomenda diretamente aos indivíduos um caminho de ação prudente como ocorre com Hobbes. A teoria da escolha racional simplesmente visa prever como os indivíduos agirão numa dada situação, se realmente agirem racionalmente no sentido estratégico. Em outras palavras, elucidam uma lógica da ação racional, mas não recomendam necessariamente que um agente valore a racionalidade e molde assim as ações dele, agente, à sua lógica ${ }^{350}$.

\footnotetext{
${ }^{347}$ SOUZA, Jessé. Ibidem, pg. 70.

${ }^{348}$ SOUZA, Jessé. Ibidem, pg. 106.

${ }^{349}$ WHITE, Stephen K. Razão, Justiça e Modernidade: A Obra Recente de Jürgen Habermas, tradução de Márcio Pugliesi. São Paulo: Ícone, 1995, pg. 22.

${ }^{350}$ WHITE, Stephen K. Ibidem, pg. 22.
} 
A tarefa de Habermas é justamente a defesa normativa da consciência moderna como ainda possuidora dos recursos necessários para nos munir de alguma orientação ético-politica mínima para com nossa "nova obscuridade", a obscuridade moral ${ }^{351}$.

Tendo em vista que a ética do passado estava profundamente associada à religião e à rígida hierarquização social da sociedade pré-moderna, para Weber o processo desencantamento do mundo é um processo irreversível do mundo moderno, na medida que retirou as condições de validade do mundo mágico-religioso, "libertando" o homem das amarras da religião. Por essa razão, segundo entende Souza, dentro da teoria social de Weber, a época de uma ética material, que funcionava como substrato das relações entre os homens e que regulava com ambições totalitárias o espaço público, pertence definitivamente ao passado ${ }^{352}$.

Dentro da perspectiva do individualismo ético apresentado por Weber, constata-se que o mundo objetivo não tem nenhum significado em si, e a tarefa de conferir significado a este mundo é uma tarefa individual e solitária. Cada qual está só com o seu Deus ou demônio que rege as escolhas significativas ${ }^{353}$. Para Habermas, essa constatação representa justamente o símbolo da perda dos vínculos de fraternidade social que culminam na perda de orientação valorativa pelo esgotamento da possibilidade de uma ética comum.

Isso porque, de acordo com a perspectiva da racionalidade estratégica, os agentes orientam sua ação conforme o agir esperado das outras pessoas. Nela, o potencial da racionalidade comunicativa permanece inutilizado, na medida em que os envolvidos coordenam seus planos de ação mediante uma influenciação recíproca, a linguagem não é empregada comunicativamente, mas de forma orientada a consequências ${ }^{354}$.

O mundo vivido é, então, "colonizado" pelo poder econômico e a política, de modo que a racionalidade instrumental, orientada estrategicamente para o sucesso independentemente de valores pré-estabelecidos, é dominante, perdendo as pessoas a liberdade, a capacidade de autodeterminação. Habermas propõe, então, um resgate do projeto iluminista, no sentido de propor a fundamentação de uma ética universal capaz de orientar o projeto da humanidade para o bem-estar e para a paz.

\footnotetext{
${ }^{351}$ WHITE, Stephen K. Ibidem, pg. 21.

${ }^{352}$ SOUZA, Jessé. Ibidem, pg. 116.

${ }^{353}$ SOUZA, Jessé. Ibidem, pg. 117.

354 HABERMAS, Jürgen. Verdade e Justificação: Ensaios Filosóficos, tradução de Milton Mota. São Paulo: Loyola, 2004, pg. 118.
} 
Tornar possível esse resgate é oferecer uma alternativa ao paradigma de racionalidade instrumental, a fim de que o senso de fraternidade possa ser recuperado, integrando o modelo de organização social que se apresenta. A democracia funciona, então, como a instituição social que possibilita a reaproximação dos indivíduos, de forma cooperativa, na tentativa de autodeterminar-se, atuando por meio do diálogo e da inclusão - simbolizada pelo direito de participação.

A partir da estrutura democrática, portanto, recupera-se a liberdade pela participação, evitando-se a dita "colonização" por força da necessidade de reflexão sobre os próprios fins, que limitam o poder econômico e o poder político. A ética do discurso é a alternativa ao modelo de sociedade apresentado por Weber, na medida em que pressupõe um paradigma de racionalidade comunicativa, fundada no assentimento individual e no consenso intersubjetivo como parâmetro de validade normativa.

Buscando "alternativas" para a Modernidade e lançando mão da teoria do agir comunicativo, afirma Habermas que numa época de politica inteiramente secularizada, não se pode ter nem manter um Estado de Direito sem democracia radical ${ }^{355}$. O autor alemão estabelece, então, uma aproximação entre a teoria do direito e a teoria da sociedade, a fim de demonstrar como o direito nas estruturas democráticas atua "reforçando" as normas morais, que, por si só, são insuficientes para garantir a estabilidade social: a figura pós-tradicional de uma moral orientada por princípios depende de uma complementação através do direito positivo ${ }^{356}$.

No item seguinte, após analisado o sentido de racionalidade instrumental, analisamse os principais postulados da ética do discurso. $\mathrm{O}$ argumento da necessidade de um resgate de uma ética universal é indispensável para o entendimento da relação entre direito e democracia apresentada por Habermas, que, nesta tese, atua como principal pressuposto teórico para a teoria do poder constituinte democrático.

A democracia é justificada como o modelo de organização política que garante o resgate da liberdade perdida com o capitalismo, atuando o Direito como instrumento que materializa as escolhas valorativas definidas no embate discursivo da política. $\mathrm{O}$ direito teria a função, assim, de tornar exigíveis, também no plano institucional do Estado, os

\footnotetext{
${ }^{355}$ HABERMAS, Jürgen. Direito e Democracia: entre faticidade e validade, v. I, tradução de Beno Siebeneichler. Rio de Janeiro: Tempo Brasileiro, 2012, pg. 13.

${ }^{356}$ HABERMAS, Jürgen. Ibidem, pg. 23.
} 
comandos morais racionalmente fundamentados. Seria, assim, um complemento à "força" da moral universal justificada com ajuda do discurso.

No momento de seu exercício originário, o poder constituinte atua como ponto de contato entre política e direito, o qual é determinante para seleção dos valores e das escolhas sobre os fins que irão orientar a sociedade no atendimento de seus objetivos. Havendo, assim, essa relação de complementaridade entre moralidade e Direito, é através do poder constituinte que as normas morais tornam-se normas jurídicas, através da “seleção" da comunidade democrática.

Passa-se, então, ao entendimento da proposta de racionalidade comunicativa como alternativa ao modelo de racionalidade estratégica.

\subsection{A Racionalidade Comunicativa e o Resgate da Ética pelo Discurso}

Conforme esclarece White, para Habermas, o processo histórico de aumentar a racionalização weberiana do mundo representa uma ameaça ao potencial pleno dos seres humanos de incluir razão no suporte dos problemas de sua existência social e política ${ }^{357}$. Parece extremamente significativo para os autores da Ética do Discurso, como Apel e Habermas, que o progresso científico e tecnológico não tenha representado um aumento no âmbito de liberdade dos sujeitos. Isso porque, conforme o cientificismo objetivista corrente no começo do século XX, a validade da ciência é independente de qualquer compromisso normativo por parte do cientista ${ }^{358}$.

Trata-se, assim, do que Maus denomina o contra-iluminismo, na medida em que o paradigma da racionalidade dominante, a racionalidade meio-fins (estratégica ou instrumental), acabou esgotando o público (e consequentemente a liberdade individual), o político foi minado pela economia e os interesses egoísticos a ela subjacentes.

A razão instrumental, restrita à racionalidade meio-fim, tinha que relegar a determinação dos fins eles próprios a decisões e atitudes cegas ${ }^{359}$, não sendo possível

\footnotetext{
${ }^{357}$ WHITE, Stephen K. Ibidem, pg. 35.

${ }^{358}$ WHITE, Stephen K. Ibidem, pg. 36.

${ }^{359}$ HABERMAS, Jürgen. Consciência Moral e Agir Comunicativo, tradução de Guido de Almeida. Rio de Janeiro: Tempo Brasileiro, 2003, pg. 61.
} 
estabelecer uma racionalidade própria para a moralidade. Desse modo, questões moralprácticas do tipo: “O que devo fazer?” são afastadas da discussão racional na medida em que não podem ser respondidas do ponto de vista da racionalidade meio-fim ${ }^{360}$.

A conclusão não satisfaz Habermas, para quem a solução para o problema do fundamento das normas do agir é um questionamento que ética filosófica, segundo Habermas, tem de resolver, a partir de uma avaliação imparcial de questões práticas, baseadas unicamente em razões. Assumindo a ética filosófica a figura de uma teoria especial da argumentação, Habermas considera a vertente da Ética do Discurso a abordagem mais promissora da atualidade ${ }^{361}$.

Partindo do pressuposto de que as normas éticas podem ser fundamentadas, a ética do discurso busca demonstrar a existência de um princípio universal de justiça baseado na noção de diálogo e de consenso. Segundo Habermas:

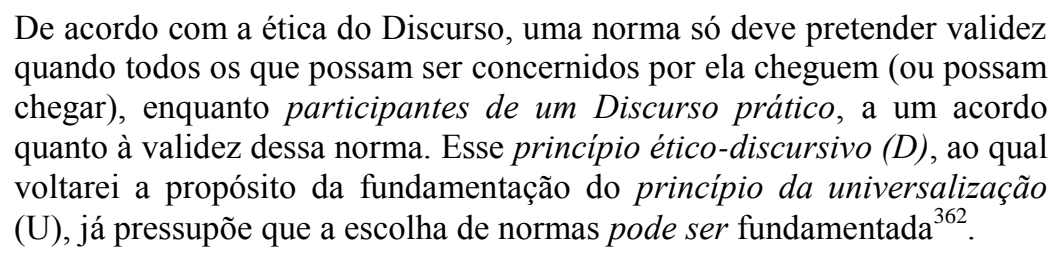

Em face da argumentação exposta por Habermas, é o princípio D uma norma universal necessária à fundamentação das normas éticas, sendo uma norma de índole procedimental, uma condição sine qua non para o esforço de fundamentação normativa. $\mathrm{O}$ princípio D não traz, em si, qualquer opção valorativa no que tange ao conteúdo das normas, a qual será alcançada através do embate discursivo mediado pelo diálogo e cujo objetivo final é o consenso.

Os questionamentos trazidos por Habermas, assim como pela ética do discurso são, portanto, contextuais: nascem de problemas morais e filosóficos próprios do século XX. Isso porque, como esclarece Oliveira, a ética contemporânea se caracteriza por ter consciência de que nossas interrogações éticas brotam de nossa situação histórica própria $^{363}$. Por esse motivo afirma Habermas, defendendo o assentimento intersubjetivo como condição da validade das normas:

\footnotetext{
${ }^{360}$ HABERMAS, Jürgen. Ibidem, pg. 63.

${ }^{361}$ HABERMAS, Jürgen. Ibidem, pg. 62.

${ }^{362}$ HABERMAS, Jürgen. Ibidem, pg. 86.

${ }^{363}$ OLIVEIRA, Manfredo de Araújo. Op. cit., pg. 9.
} 
As necessidades são interpretadas à luz de valores culturais; e como estes são sempre parte integrante de uma tradição partilhada intersubjetivamente, a revisão dos valores que presidem à interpretação das necessidades não pode de modo algum ser um assunto do qual os indivíduos disponham monologicamente ${ }^{364}$.

Desse modo, como esclarece Habermas, as normas fundamentadas de tal modo exprimem uma vontade universal, já que o princípio moral exclui como inválidas as normas que não possam encontrar o assentimento qualificado de todos os concernidos possivveis $^{365}$. Com isso, ao mesmo tempo em que Habermas parte de Kant e seu esforço de fundamentação racional da moralidade, vai além da filosofia kantiana ao rejeitar a solução monológica proposta pelo filósofo autor da Fundamentação da Metafísica dos Costumes.

A fundamentação das normas éticas só é possível mediante um diálogo onde os participantes atuem de forma colaborativa. Diferenciado o agir estratégico do agir comunicativo, Habermas estabelece que, enquanto aquele é orientado para o sucesso, independentemente das razões, este, o agir comunicativo, pressupõe uma ação de adesão, uma tentativa dos sujeitos de alcançar o acordo para coordenar os planos de ação. É o agir comunicativo, portanto, um agir eminentemente racional, na qual todos os sujeitos se comprometem em reconhecer a melhor razão, sendo necessário, assim, assumir a perspectiva do outro ${ }^{366}$.

Para Neves, o discurso, como nível reflexivo que emerge da prática cotidiana e, ao mesmo tempo, constrói-se recorrendo ao mundo da vida como pano de fundo, introduz-se exatamente quando se questiona uma das pretensões de validade na interação concreta. Desse modo, em interpretação à teoria da ação comunicativa habermasiana, Neves afirma que:

\footnotetext{
Conforme o princípio formal-pragmático da fundamentação, só são admitidas racionalmente como válidas as assertivas ou prescrições que poderiam ser aceitas por qualquer um que se encontrasse idealmente na mesma situação dos participantes do discurso. Tanto no campo da verdade como no da normatividade, o consenso racional, entendido como capacidade de generalização a partir das condições ideais do discurso, é o critério de determinação de validade ${ }^{367}$.
}

\footnotetext{
${ }^{364}$ HABERMAS, Jürgen. Ibidem, pg. 88.

${ }^{365}$ HABERMAS, Jürgen. Ibidem, pg. 84.

${ }^{366}$ HABERMAS, Jürgen. Ibidem, pg. 86.

${ }^{367}$ NEVES, Marcelo. Entre Têmis e Leviatã: Uma Relação Difícil. São Paulo: Martins Fontes, 2008, pg. 77.
} 
A fundamentação da moral é, portanto, o ponto de partida para a teoria da sociedade de Habermas, que objetiva encontrar níveis de integração e solidariedade social em tempos de hipercomplexidade e inexistência de um paradigma comum de moralidade.

Oliveira analisa o papel do consenso na teoria habermasiana, explicando o sentido de consenso qualificado ou legitimado. Desse modo, tem-se que a justificação discursiva significa consenso, não no sentido de um acordo casualmente realizado, mas no sentido de que qualquer parceiro possível da conversa atribuirá o mesmo predicado ao objeto em tela $^{368}$.

A definição dos critérios de fundamentação da norma moral é, portanto, um pressuposto para o resgate da legitimidade do Direito, possível mediante a racionalização dos enunciados normativos, da demonstração de sua exigibilidade como um imperativo da razão. Isso porque o direito, apesar de servir como instrumento de poder, precisa de justificação moral, na medida em que, mesmo a intervenção instrumental no direito exige $o$ respeito a procedimentos baseados em princípios universais ${ }^{369}$. Neves complementa a análise, ao esclarecer a perspectiva habermasiana sobre a relação de complementaridade existente entre o Direito e a Moralidade:

A normatividade refere-se à validade e, portanto, exige fundamentação
moral ou, mais abrangentemente, justificação discursiva do direito. Nesse
sentido, as normas são concebidas em uma perspectiva universalista,
sendo definidas como "expectativas de comportamento cuja
vinculatoriedade normativa apresenta um certo parentesco com a força
motivadora das afirmações verdadeiras. [...] A normatividade, que se
fundamenta em princípios no estádio da moral pós-convencional, diz
respeito ao "dever-ser" (Sollen) universalista, incondicionado"

Por isso que, segundo Neves, para Habermas moral e direito referem-se aos mesmos problemas, não devendo ser apagadas as fronteiras entre direito e moral, uma vez que uma ordem jurídica só pode ser legítima se não contradisser os princípios morais ${ }^{371}$.

Karl-Otto Apel também oferece a sua contribuição ao problema do fundamento na ética filosófica, explicando o contexto de desenvolvimento da ética do discurso em face da racionalidade instrumental e a insuficiência da posição que relega a eticidade ao campo das preferências pessoais. Parece claro para o professor da Universidade de Frankfurt que os

\footnotetext{
${ }^{368}$ OLIVEIRA, Manfredo de Araújo. Reviravolta Linguístico-Pragmática na Filosofia Contemporânea. São Paulo: Loyola, 2006, pg. 313.

${ }^{369}$ NEVES, Marcelo. Ibidem, pg. 110.

${ }^{370}$ NEVES, Marcelo. Ibidem, pg. 111.

${ }^{371}$ NEVES, Marcelo. Ibidem, pg. 117.
} 
resultados da ciência representam um desafio moral para a humanidade ${ }^{372}$. A capacidade de destruição provocada pelo avanço da técnica torna cada vez mais necessária a definição de parâmetros morais que orientem o progresso científico para a paz.

O questionamento tão caro à ética do discurso é bem exposto por Apel no texto intitulado "O a priori da comunidade de comunicação e os fundamentos da ética: o problema de uma fundamentação racional da ética na era da ciência”. Segundo Costa, intérprete da obra de Apel:

Podemos concluir, portanto, com Apel, que na nossa moderna civilização industrial nunca foi tão premente e tão urgente a necessidade de uma ética universal da responsabilidade solidária que regule as ações humanas a ponto de enfrentar as consequências das incursões técnico-científicas do homem na natureza e, com isso, evitar um futuro apocalíptico ou catastrófico capaz de extinguir a vida humana e planetária ${ }^{373}$.

Apel apresenta o problema da fundamentação da ética como um verdadeiro paradoxo, uma vez que de um lado, a carência de uma ética universal, isto é, vinculadora para a toda sociedade humana, nunca foi tão premente como em nossa era, em virtude da potencialidade destrutiva dos avanços tecnológicos; de outro lado, a tarefa filosófica de uma fundamentação racional de uma ética universal jamais parece ter sido tão complexa, e mesmo sem perspectiva, do que na idade da ciência, na qual o paradigma da "objetividade-neutralidade" encontrou o seu lugar ${ }^{374}$.

O filósofo alemão entende que o advento de uma moral universal capaz de integrar a sociedade e fortalecer os vínculos de solidariedade é, sobretudo, uma questão de sobrevivência em tempos de complexidade e diversidade cultural. As morais tradicionais, típicas do período pré-moderno, não são mais capazes de dar conta dos conflitos nascidos de sociedades multiculturais, nas quais as expectativas e os valores são tão múltiplos quanto conflitantes. Essa ética universal nascida da razão é, para Apel, uma alternativa à desintegração provocada pelas morais tradicionais, sendo capaz de reunir em um contexto discursivo sujeitos comprometidos unicamente com a melhor razão, independentemente do conteúdo da norma sob exame.

Como esclarece, na atualidade, as morais de grupos, geralmente enraizadas em instituições e tradições arcaicas, já não conseguem mais compensar aquela perturbação

\footnotetext{
${ }^{372}$ APEL, Karl-Otto. Estudos de Moral Moderna, tradução de Benno Dischinger. Petrópolis: Vozes, 1994, pg. 71.

373 COSTA, Regenaldo da. Ibidem, pg. 175.

374 APEL, Karl-Otto. Ibidem, pg. 69.
} 
de equilíbrio constitutiva para o homo faber $^{375}$. E, apesar dessa diversidade cultural, temse que a civilização técnico-científica confrontou todos os povos, raças e culturas, sem consideração de suas tradições morais grupalmente específicas e culturalmente relativas, como uma problemática ética comum a todos ${ }^{376}$.

Os problemas éticos referentes à sobrevivência da humanidade, do combate à destruição dos ecossistemas são indicados por Apel como exemplos de questões que interessam a todas as culturas independentemente de suas tradições e de sua moral, sendo apresentadas como verdadeiras questões éticas universais, a própria "ética na era da ciência", no dizer do filósofo alemão.

Ao mesmo tempo em que o potencial destrutivo é tão arrasador e alarmante, constata-se que as ciências parecem propor um argumento empírico adicional para a subjetividade e irracionalidade das normas de moral e dos valores ${ }^{377}$, levando a ética ao campo das preferências, insuscetível, portanto, de uma elaboração racional e universalmente válida. O filósofo compreende que a ciência e sua racionalização instrumental e estratégica da parte técnica necessitam de parâmetros objetivos para tomada de decisões sobre quais são os objetivos da práxis, uma vez que ela não fornece nenhuma racionalização da escolha dos próprios fins ${ }^{378}$.

Afirma Apel:

É que elas [as ciências] chegam - como se ouve com frequência - ao juízo de fato, objetivamente válido, de que as normas de moral, aceitas ou praticamente seguidas por seres humanos, são, em alta escala, relativamente culturais ou, respectivamente, epocais, e isso quer dizer novamente: subjetivas ${ }^{379}$.

Como, então, conviver com a necessidade de uma ética comum e, ao mesmo tempo, refutar a possibilidade racional de normas para o agir fundamentadas e exigíveis por todas as culturas? Esse o problema que a ética do discurso busca resolver.

\footnotetext{
375 APEL, Karl-Otto. Ibidem, pg. 70.

${ }^{376}$ APEL, Karl-Otto. Ibidem, pg. 71.

${ }^{377}$ APEL, Karl-Otto. Ibidem, pg. 72.

${ }^{378}$ APEL, Karl-Otto. Ibidem, pg. 83.

${ }^{379}$ APEL, Karl-Otto. Ibidem, pg. 73.
} 


\subsubsection{O Argumento Apeliano pela Possibilidade de uma Fundamentação}

Apel tenta apresentar uma solução para o problema da fundamentação ética e começa seu percurso argumentativo pela demonstração lógica de sua possibilidade. A análise do texto de Apel mostra-se útil nesta tese, na medida em que Habermas, em sua proposta de fundamentação da moral e, especificamente, em sua teoria procedimentalista sobre a democracia, já parte da ideia de que a fundamentação de normas éticas é possível, mediante uma forma de racionalidade própria, a razão comunicativa.

A “desconfiança” que a comunidade científica deposita em relação à possibilidade de racionalização da ética é explicada por Apel, ao indicar e refutar os pressupostos que supostamente demonstram a impossibilidade de uma fundamentação das normas morais.

O primeiro pressuposto resume-se ao que o Apel denomina "princípio de Hume": tem-se que de fatos não se podem deduzir normas, isto é, da descrição/explicação da realidade (atividade própria das ciências) não é possível deduzir prescrições objetivas, ou juízos de valor, na medida em que as ciências sobre fatos são moralmente livres de valoração. O princípio de Hume é fortemente refutado por Apel, para quem é profundamente questionável se todas as ciências que têm conteúdo empírico são por isso puras $^{380}$.

No segundo, afirma-se que a ciência, enquanto fornece conhecimentos de conteúdo, trata de fatos; por isso uma fundamentação científica de uma ética normativa é impossivel. E, por fim, como terceiro pressuposto, reconhece-se que somente a ciência fornece um saber objetivo, intersubjetivamente válido, razão pela qual uma fundamentação intersubjetivamente válida de uma ética normativa é absolutamente impossível ${ }^{381}$. Na medida em que a ética trata não de fatos, mas de mandamentos de conduta, não explica o que é, mas estipula o que deve ser, não seria possível estabelecer parâmetros racionais para o dever-ser almejado pela ética normativa, por se tratar de um saber alheio à racionalidade científica.

A crítica de Apel se funda na ideia de que tanto as ciências naturais, em menor grau, como as ciências humanas empíricas são incapazes de constituir (ou explicar) seu objeto

\footnotetext{
${ }^{380}$ APEL, Karl-Otto. Ibidem, pg. 91.

${ }^{381}$ APEL, Karl-Otto. Op. cit.
} 
sem uma valoração moral ${ }^{382}$. De acordo com Apel, as ciências humanas tratam da reconstrução compreensiva de ações, obras e instituições humanas, em suma: da autocompreensão da práxis vital humana a partir da sua história ${ }^{383}$, o que remonta à já clássica distinção metodológica entre ciências humanas e ciências naturais propostas por Dilthey, para a qual as ciências humanas operam no plano da explicação e não da descrição.

Mesmo quando, deliberadamente, as ciências humanas tentaram se isentar de uma postura valorativa, o resultado foi insatisfatório, conforme explica Apel ao analisar o historicismo positivista:

Esta neutralização metódica, no entanto, em primeiro lugar jamais poderá fazer desaparecer a assim chamada perspectiva de valoração précientífica. Mesmo no caso de o historiador se esforçar uma fundamentação histórico-imanente objetiva dos juízos significativos, sua representação seletiva e exposição narrativa da história em seu todo - e, principalmente, sua compreensão "apreciativa" de pessoas e épocas particulares - continua, não obstante, essencialmente determinada pela perspectiva de valoração, que provém do fato de o historiador praticamente fazer parte da história ${ }^{384}$.

Conforme explica o filósofo alemão, a atividade científica não está isenta de valorações, na medida em que o cientista co-determina a constituição do objeto, através da linguagem, também situada no horizonte de pré-compreensão do sujeito ${ }^{385}$. Em verdade, Apel atribui uma responsabilidade ao cientista quanto à avaliação da escolha dos meios científicos, como também dos fins. Esta passagem pode ser especialmente esclarecedora:

Em contraposição a isso, no sentido de uma hermenêutica valorativa não neutra, eu gostaria de ater-me, por enquanto, ao seguinte: quem quiser entender ações humanas (incluindo "atos de fala") deverá - nem que o faça sob a reserva metódica de um posterior estranhamento (alienação) e neutralização - engajar-se, ao mesmo heuristicamente, no sentido da corresponsabilidade das intenções que visam ação. [...] Isso que quer dizer que eles [ os dados] devem primariamente - mesmo sob a reserva de uma posterior alienação e neutralização - ser constituídos a partir de uma concepção simultaneamente comunicativa e auto-reflexiva, e isso significa: hermenêutica ${ }^{386}$.

Segundo o filósofo, a compreensão do papel do intérprete na constituição do objeto da ciência, através do círculo hermenêutico e do entender e do valorar, deve ser utilizado como uma garantia contra a cegueira valorativa, não no sentido de se negar a possibilidade

\footnotetext{
${ }^{382}$ APEL, Karl-Otto. Ibidem, pg. 91.

${ }^{383}$ APEL, Karl-Otto. Ibidem, pg. 94.

${ }^{384}$ APEL, Karl-Otto. Op. cit.

385 APEL, Karl-Otto. Op. cit.

${ }^{386}$ APEL, Karl-Otto. Ibidem, pg. 99.
} 
de uma ética universal, mas como pressuposto de que, ao interpretar, o sujeito do conhecimento já está se posicionamento moralmente, e, portanto, inexiste o paradigma da neutralidade.

O avanço da hermenêutica deve ser entendido, conforme esclarece Apel, como um progresso eticamente relevante na formação social da humanidade, como comunidade de interpretação e interação ${ }^{387}$. Embora a hermenêutica não dê conta da fundamentação de uma ética universal, seu surgimento no quadro das teorias filosóficas na passagem do século XIX para o século XX foi, sem dúvida, determinante para a abertura de um caminho rumo ao "engajamento" ético das ciências. Como afirma Apel, as ciências huamanas, eticamente engajadas, podem dar conta, através de uma avaliação crítica, da multiplicidade das normas e dos valores vividos $e-d e$ forma complementar à "informação" científico-tecnológica da sociedade - desenvolver a sua relação de práxis na "formação" de uma sociedade eticamente engajada ${ }^{388}$.

Para o alemão, tanto a verdade das sentenças teóricas sobre fatos como a validade das normas morais são questionáveis, em níveis diferentes do discurso. A pretensão de validade normativa é, para Apel, um pressuposto transcendental, na medida em que toda norma, uma vez posta, traz consigo a pressuposição de sua validade, de seu poder de ordenar com base em razões determinada ação ou omissão. Afirma o filósofo que $a$ existência fática da pretensão normativa de validade é a que justamente não pode ser colocada entre parênteses; antes deve a validade problematizada das normas, metodicamente a título de prova, ser aduzida ao fato de pretensão de validade, a fim de justificar a pretendida validade ${ }^{389}$.

Isso significa que no discurso a pretensão de verdade das afirmações sobre fatos e de validade sobre as normas é uma condição insuperável, do ponto de vista racional, pois uma sentença não pode ser, ao mesmo tempo, uma afirmação e uma negação em si mesma. Quando se descreve determinada lei matemática, ou se prescreve determinado comando, a sentença pressupõe a verificabilidade racional daquele fato ou daquela ordem como uma condição fundamental (e universal) da linguagem e do discurso.

\footnotetext{
${ }^{387}$ APEL, Karl-Otto. Ibidem, pg. 105.

${ }^{388}$ APEL, Karl-Otto. Ibidem, pg. 106.

${ }^{389}$ APEL, Karl-Otto. Op. cit.
} 
Conforme o pensamento de Apel, portanto, a pressuposição da validade de normas morais como tais é condição "paradigmática" de possibilidade do jogo de linguagem pertencente à justificação de normas. Tal pressuposição seria, em verdade, uma verdadeira norma moral básica ou um principio de ética ${ }^{390}$.

A tese de Apel vai no sentido de que o princípio de racionalidade, representado pelo cumprimento das regras lógicas de um pensamento consequente, apresenta eo ipso um fundamento da ética, na medida em que, como afirma o filósofo:

A validade lógica de argumentos não pode ser examinada sem se
pressupor, em princípio, uma comunidade de pensadores, habilitados à
compreensão intersubjetiva e à formação do consenso. Mesmo o
pensador, de fato isolado, só pode explicitar e examinar sua
argumentação, enquanto ele, numa crítica "conversa da alma consigo
mesma" (Platão), consegue internalizar o diálogo de uma potencial
comunidade de argumentação. Aí se mostra que a validade de um
pensamento solitário depende, em princípio, da justificação de afirmações
linguísticas, na atual comunidade de argumentaçãa ${ }^{391}$.

Para alcançar a fundamentação da norma moral, o filósofo indica "condições ideais de discurso" sem as quais o trabalho de justificação lógica é impossível: mentir, por exemplo, tornaria certamente impossível o diálogo do argumentante, razão pela qual é necessário, dentro da perspectiva procedimental, indicar os caminhos por meio dos quais a fundamentação normativa se faz possível.

A distinção entre o lado performativo e o lado proposicional da fala é fundamental para a compreensão do pressuposto transcendental de Apel. Enquanto o lado proposicional busca a definição de sentenças sobre fatos e a sua explicação, o aspecto performativo das ações comunicativas buscam o convencimento do outro, a demonstração de que a sua razão é aquela que deve prevalecer no discurso. Apel dá um exemplo, com a seguinte sentença: "Eu desafio, com isto, a cada um, a examinar a seguinte afirmação". Para o filósofo, esse lado performativo, voltado à adesão do interlocutor, é o que pressupõe a existência de uma ética.

A ética universal de Apel, portanto, é uma ética da argumentação, no sentido de que o sujeito se compromete com a lógica e a ciência como meio para definir as melhores

\footnotetext{
${ }^{390}$ APEL, Karl-Otto. Ibidem, pg. 110.

${ }^{391}$ APEL, Karl-Otto. Ibidem, pg. 115.
} 
razões. Em outras palavras, a ética pressuposta pela lógica, como condição de sua possibilidade, implica, por conseguinte, o dever para o emprego da lógica e da ciência ${ }^{392}$.

Desse modo, tem-se, com a contribuição de Apel, uma argumentação forte no sentido da demonstração não só da possibilidade como da necessidade da fundamentação da ética, como condição de desenvolvimento da sociedade e de sua reintegração. Para Apel, a racionalidade científica marcada pelo objetivismo não dá conta dos problemas dos fins, cuja estipulação é indispensável para a condução do progresso tecnológico na era da ciência.

É nesse ponto que Apel se aproxima de Habermas, ao recusar a existência de uma ética deontológica que já indique, de princípio, comandos de ação independentemente do assentimento dos argumentantes, no sentido de uma "metafísica". A validade normativa está, assim, associada ao consenso e à adesão, como o resultado de um processo dialógico e discursivo cujo objetivo primordial é encontrar a melhor razão dentre todos os argumentos apresentados.

\subsection{Teoria Crítica da Sociedade Moderna e Razão Comunicativa}

Nascido em Düsseldorf no ano de 1929, Habermas vivenciou sua juventude acadêmica e chegou à maturidade intelectual no mundo europeu do pós-segunda guerra, numa sociedade marcada pela ascensão dos regimes totalitários na Europa e pelo massacre sistematizado de civis pelos exércitos nacionais. Situando seus estudos principais no âmbito da sociologia, Habermas propõe uma teoria crítica da sociedade moderna fundada na noção da racionalidade comunicativa. Cumpre esclarecer, a princípio, o que o autor compreende por sociedade moderna - conceito fundamental para a compreensão da transformação do direito e das formas de interação que implicaram na institucionalização da democracia.

Enquanto que na sociedade tradicional, todos os domínios da vida social encontram-se referidos a um conjunto de valores religiosos ou míticos que dão sentido a cada uma das ações individuais e coletivas, na sociedade moderna observa-se a

${ }^{392}$ APEL, Karl-Otto. Ibidem, pg. 120. 
convivência de uma pluralidade de eticidades, vale dizer, a convivência em um mesmo espaço político de uma pluralidade de concepções de mundo e de formas de vida ${ }^{393}$.

Habermas sustenta, portanto, ser a quebra dos vínculos de integração social baseados nos fundamentos religiosos ou metafísicos como um fator distintivo da transformação da sociedade tradicional em sociedade moderna, sendo necessário apresentar uma nova alternativa de legitimação da ordem social.

A unidade própria da sociedade tradicional é materializada em uma eticidade comum, ou "modo de vida compartilhado": há não apenas um conjunto de valores compartilhados, mas também atitudes na vida prática correspondentes a esses valores que devem ser observadas por todos os membros da comunidade. Dentro de uma estrutura onde a complexidade social é contida pelo ethos comum, os problemas fundamentais referentes à organização da sociedade ou mesmo as indagações sobre a origem do mundo advém de uma interpretação única, imposta sistematicamente dentro de uma estrutura rígida e hierarquizada ${ }^{394}$.

Nas organizações tradicionais, tem-se por fundamento de legitimidade do poder uma tradição sagrada e incontestável, constatando-se uma total coincidência entre a unidade espiritual e a unidade política, de modo que:

O pertencimento dos indivíduos a uma comunidade política confunde-se
como o reconhecimento de compartilhar uma mesma forma de vida, as
mesmas crenças e os mesmos princípios de conduta na vida prática, em
suma, uma mesma eticidade
395.

A sociedade moderna, por sua vez, é o produto de uma série de transformações sociais, políticas, econômicas e filosóficas que permearam os acontecimentos políticos desde o século XVIII, nos países marcados pela cultura ocidental. A construção da subjetividade, o reconhecimento dos direitos individuais e da necessária configuração do poder político a partir da tripartição de suas funções (o poder político autolimitado), a consolidação do modelo econômico capitalista representam, cada uma em seu âmbito, transformações responsáveis pelo incremento da complexidade social. A consequência primordial é a desagregação dos vínculos de crença e de legitimidade que mantinham a coesão e a ordem na sociedade tradicional.

\footnotetext{
${ }^{393}$ NOBRE, Marcos; TERRA, Ricardo (orgs.). Direito e Democracia: um guia para leitura de Habermas. São Paulo: Malheiros, 2008, pg. 16.

${ }^{394}$ NOBRE, Marcos et ali. Ibidem, pg. 15.

${ }^{395}$ NOBRE, Marcos et ali. Ibidem, pg. 16.
} 
Esse processo de "desintegração" é simbolizado pelo dissenso e pelo incremento da complexidade social. Tal dissenso se expressa de diversas maneiras, em diversos domínios da vida social e exige uma reorganização radical por parte dos atores. De acordo com Nobre et ali, a partir dessa nova organização social moderna, já não é mais possível legitimar a ordem social pela referência à tradição, porque a própria ideia de tradição está abalada, porque cada concepção de mundo constrói a sua própria "tradição”,396.

Analisando a ideia de dissenso como fator característico das sociedades modernas, Neves esclarece que sua manifestação não se dá apenas na diversidade valorativa (ou pluralidade éticas), mas igualmente na existência de uma multiplicidade de âmbitos autônomos de discussão e esferas discursivas ${ }^{397}$. Na medida em que o surgimento de uma moral tradicional compartilhada pelo grupo não se faz mais possível, por força das especificidades culturais diversas, o que Neves denomina dissenso estrutural passa a ser a nota distintiva da esfera pública verdadeiramente democrática: reconhece-se a não concordância quanto aos valores, mas tem-se um consenso quanto ao direito de participação e quanto à necessidade de um diálogo plural e contínuo que seja capaz de incorporar e mediar o dissenso.

Para Neves:

Na compreensão da esfera pública, deve-se partir exatamente do dissenso
estrutural já presente, em primeiro grau, na prática cotidiana de uma
sociedade supercomplexa. Trata-se da intermediação generalizada desse
dissenso, não de sua amortização ou evitação. [… Ȧ medida que se
constroem procedimentos constitucionais para viabilização,
intermediação e absorção do dissenso, a esfera pública pluralista emerge
do mundo da vida em forma de interesses, valores e discursos que
pretendem, através desses procedimentos, generalizar-se politicamente,
isto é, como decisão coletivamente vinculante, e/ou juridicamente, a
saber, como norma jurídica vigente.

Reconhece-se, assim, a impossibilidade de que um consenso quanto ao conteúdo das normas morais seja alcançado em tempos de difusão dos valores e dos códigos morais. A sociedade precisa absorver essa complexidade, criando vínculos de solidariedade que independam do compartilhamento de uma moral única. Dentro dessa perspectiva, a saída capaz de mediar os conflitos e as tensões provocadas pela hipercomplexidade é justamente a organização do arcabouço institucional do estado a partir do modelo democrático.

\footnotetext{
${ }^{396}$ NOBRE, Marcos et ali. Ibidem, pg. 16.

${ }^{397}$ NEVES, Marcelo. Entre Têmis e Leviatã: Uma relação difícil. São Paulo: Martins Fontes, 2008, pg. 129.
} 
Na democracia institucionalizada, tem-se a positivação do direito de participação e o reconhecimento de principio sobre a igualdade entre os sujeitos na sociedade política, independentemente de sua origem, poder econômico ou pertencimento a classe social. A constituição atua, aqui, como um elemento de estabilização dos conflitos sociais difundidos entre as diversas classes, ao mediar o diálogo entre o direito e a política. Por essa razão afirma Neves que:

Este é o desafio fundamental do Estado Democrático de Direito em face da esfera pública, isto é, a estruturação dela através da canalização e intermediação procedimental (universalista e pluralista) dos enormes conflitos que a caracterizam, conflitos de expectativas, valores, interesses e discursos $^{398}$.

Desse modo, tem-se uma inicial "desestruturação" da esfera pública enquanto arena do dissenso. Como esclarece Neves, ela só se torna, em certa medida, estruturada quando há perspectivas de que as expectativas, os valores, os interesses e os discursos que lhe são constitutivos sejam generalizados pelos procedimentos constitucionais ${ }^{399}$. A constituição assume, assim, um papel fundamental para a organização da democracia no estado moderno, pois é a partir dela que o dissenso pode ser intermediado através de procedimentos inclusivos e pluralistas.

A racionalidade comunicativa é, para Habermas, um pressuposto para a construção do consenso na esfera pública, imprescindivel à indisponibilidade do direito e decorre diretamente do desaparecimento da moral tradicional, conteudística e hierárquica. $\mathrm{O}$ estado de direito legitima-se, então, na medida em que institui procedimentos inclusivos de participação por meio dos quais os diversos grupos sociais possam levantar suas pretensões normativas e, havendo o consenso, possam positivá-las, legislando e criando o Direito.

A constituição é o lugar de institucionalização e organização dos procedimentos democráticos, como o processo legislativo e o processo judicial. Ela cria as normas procedimentais, estabelece as condições de participação dos sujeitos, determina as competências e organiza as instituições que tornam viável o Estado como instituição predominante na sociedade. Ela estrutura, portanto, a esfera pública, através da canalização dos conflitos como tensões internalizadas ao sistema político.

Por essa razão, o exercício do poder constituinte é justamente o que condiciona o êxito do estado como estrutura democrática. A falha na organização procedimental tem

\footnotetext{
${ }^{398}$ NEVES, Marcelo. Ibidem, pg. 135.

${ }^{399}$ NEVES, Marcelo. Op. cit.
} 
como consequência a não estruturação da esfera pública, culminando na incapacidade de intermediação do conflito e do restabelecimento dos laços de solidariedade e fraternidade necessários à sociedade moderna.

A ética do discurso, que se define como uma ética procedimental, não conteudística, compreende que o aspecto verdadeiramente universal de uma ética possível para a sociedade hipercomplexa da modernidade é justamente o consenso quanto ao direito de participação. Em outras palavras, garante-se que os sujeitos possam debater, em um espaço público participativo e organizado, sobre as normas orientadoras do agir, a fim de que possam chegar a um acordo quanto às melhores razões.

O direito atua, então, como uma instância complementar em relação à moral, e que tem por função converter o poder comunicativo em poder administrativo ${ }^{400}$, razão pela qual se vislumbra, na teoria habermasiana, uma estreita relação entre a ética, o direito e a democracia, em torno de uma teoria sobre a sociedade voltada ao problema da fundamentação e da legitimidade.

A recuperação dos vínculos de solidariedade é possível, com Habermas, a partir do resgate do equilíbrio entre o público e o privado, como esclarece Neves:

A teoria do discurso pretende fundamentar o equilíbrio da autonomia
privada e da autonomia pública, apontando para o fato de que os direitos
humanos só podem estar garantidos onde esteja assegurado o princípio da
soberania do povo, ou seja, o procedimento democrático de formação da
vontade estatal ${ }^{401}$.

Pode-se perceber, portanto, que o dissenso, a hipercomplexidade e a tensão são notas características da sociedade moderna, em contraposição à sociedade tradicional.

A distinção estrutural entre sociedade tradicional e sociedade moderna é também desenvolvida por Neves em obra recente. O autor esclarece que, inexiste, na sociedade prémoderna, o conceito de pessoa, a integração social não poderia relacionar-se com a instituição de direito, mas sim com a atribuição de privilégios de status $^{402}$, em geral associados à ordem religiosa. Observa-se, assim, o estabelecimento de uma estrutura política de dominação, na qual toda a vida social estava submetida imediatamente à

\footnotetext{
${ }^{400}$ NEVES, Marcelo. Ibidem, pg. 119.

${ }^{401}$ NEVES, Marcelo. Ibidem, pg. 117.

${ }^{402}$ NEVES, Marcelo. Transconstitucionalismo. São Paulo: Martins Fontes, 2009, pg. 9.
} 
diferença entre poder superior e inferior, que, por sua vez, se fundava diretamente na cosmovisão religiosa orientadora da diferença entre o bem e mal ${ }^{403}$.

Para Neves, o próprio constitucionalismo, como movimento político e jurídico nascido na Modernidade, deve seu surgimento ao caráter multicêntrico ${ }^{404}$ da sociedade que nasce com a ruptura da ordem tradicional. A integração existente na sociedade tradicional sustentava-se tanto pela estrutura política de dominação como semântica moral-religiosa. Nessa perspectiva, uma vez que não se tinha desenvolvido ainda o conceito de pessoa, a integração não estava relacionada ao reconhecimento de direitos, mas com a atribuição de privilégios ou status ${ }^{405}$.

Com o processo de dessacralização do Direito observado no advento da Modernidade, surge um novo modelo de organização social, intitulada por Habermas e seus intérpretes como sociedade moderna. As primeiras cartas de direitos representam, aqui, o início da vinculação jurídica do poder, dando fim ao estado absoluto que representava uma ordem de dominação legitimada pelo direito sacro. Insustentável o argumento do direito divino, é necessário, então, forjar um novo discurso de legitimação que assente o Estado Liberal de Direito em bases inteiramente novas ${ }^{406}$.

O crescimento da complexidade social na modernidade, decorrente do que Neves denomina diferenciação funcional, é resultado, no dizer do autor, de processos sociais traumáticos, com consequências destrutivas para o ambiente biológico e psíquico dos sistemas sociais $^{407}$. Afirma o autor:

O incremento da complexidade social levou ao impasse da formação social diferenciada hierarquicamente na pré-modernidade, fazendo emergir a pretensão crescente de autonomia das esferas de comunicação, em termos de sistemas diferenciados funcionalmente na sociedade moderna. Há não só um desintrincamento de lei, poder e saber, nem apenas a obtenção da liberdade religiosa e econômica pelo homem, mas um amplo processo de diferenciação sistêmico-funcional ${ }^{408}$. Mediante esse processo, a sociedade torna-se "multicêntrica" ou "policontextual".

Considerando que a sociedade moderna é formada por racionalidades conflitantes, cada uma delas com pretensão de universidade, a tensão daí resultante só pode levar à sua própria autodestruição, razão pela qual se mostra imperioso encontrar um "ponto de

\footnotetext{
${ }^{403}$ NEVES, M. Ibidem, pg. 11.

${ }^{404}$ NEVES, M. Ibidem, pg. XXIII.

${ }^{405}$ NEVES, M. Ibidem, pg. 8.

${ }^{406}$ NEVES, M. Ibidem, pg. 20.

${ }^{407}$ NEVES, M. Ibidem, pg. 22.

${ }^{408}$ NEVES, M. Ibidem, pg. 23.
} 
contato" que permita a mediação dos conflitos e das tensões dentro de uma estrutura minimamente organizada.

A alternativa encontrada pela proposta habermasiana é a institucionalização da democracia, que permite a inclusão dos diferentes grupos sociais e positiva o direito de que todos, em igualdade, possam levantar pretensões de validade normativa na esfera pública. Essa estrutura participativa e inclusiva, orientada conforme os postulados da racionalidade comunicativa, ao mesmo tempo em que fundamenta o direito e condiciona as ações do estado, "estabiliza" a hipercomplexidade e a tensão dela resultante, evitando, portanto, o processo de autodestruição mencionado por Neves.

Em análise que vai ao encontro do pensamento de Habermas e de Neves, GoyardFabre situa a modernidade como um momento de ruptura com o cosmologismo do pensamento antigo e o teologismo do pensamento medieval. A consequência é uma dispersão, no sentido do abandono de uma unidade ética absoluta ${ }^{409}$.

Habermas, portanto, considerando a explicação que se oferece para a sociedade moderna e suas peculiaridades, se propõe a apresentar uma teoria sobre a sociedade que dê conta de sua hipercomplexidade e seja capaz de recuperar os vínculos de solidariedade, evitando, assim, a destruição da própria sociedade. Para tanto, mostrou-se necessário superar o domínio paradigma da racionalidade estratégica, orientada exclusivamente para o sucesso, e apresentar o paradigma da racionalidade comunicativa, voltada para o entendimento e para o consenso.

A racionalidade comunicativa impõe um compromisso racional, no sentido de que, partindo de condições ideais de discurso, uma norma só se considera válida se a ela possam assentir todos os participantes possíveis no debate. É, portanto, uma racionalidade inclusiva, que parte da garantia do direito de participar como condição de validade do próprio resultado normativo. A observância do procedimento é o que legitima, portanto, o consenso alcançado quanto ao conteúdo da norma apresentada.

Em Habermas, a teoria do agir comunicativo e da racionalidade é o que constitui fundamento de uma teoria crítica da sociedade, tendo aberto os caminhos para uma

\footnotetext{
${ }^{409}$ GOYARD-FABRE, Simone. Os Princípios Filosóficos do Direito Político Moderno, tradução de Irene Paternot. São Paulo: Martins Fontes, 1999, pg. 38.
} 
concepção da moral, do direito e da democracia ancorada na teoria do discurso ${ }^{410}$. A capacidade de distanciamento de si e abertura ao outro, pelo diálogo, é, em verdade, uma condição indispensável à própria liberdade de sujeito, conforme esclarece o filósofo alemão $^{411}$. Por isso que a democracia é, em última análise, uma imposição da razão, mais do que uma simples escolha de sistema político entre outros possíveis. A teoria do agir comunicativo, a teoria da sociedade e a teoria do direito, em Habermas, formam um argumento, pressupondo-se mutuamente, conforme se intentou demonstrar até este ponto.

Assumir uma postura aberta ao diálogo é a virtude verdadeiramente democrática, conforme demonstra a teoria do agir comunicativo. A superação de uma perspectiva egocêntrica por uma perspectiva dialogal é explicada por Habermas com as seguintes palavras:

\begin{abstract}
Liberdade reflexiva, no sentido de ausência de restrições cognitivas, exige a libertação da perspectiva egocêntrica própria de um participante enredado no contexto de ação - aquela liberdade que tradicionalmente associamos à atitude teórica. [...] A liberdade ética possibilita, por fim, o projeto consciente a estabilização de uma identidade do eu. Por certo, essas liberdades são disposições que se podem atribuir a uma pessoa; mas as auto-referências correspondentes devem-se, cada uma, à adoção e à interiorização da perspectiva que outros participantes da argumentação têm diante de $\mathrm{mim}^{412}$.
\end{abstract}

Conforme a proposta habermasiana, o sujeito só pode ser considerado efetivamente livre em face de sua relação com o outro. É por essa razão que a superação da razão monológica pensada por Kant se fez necessária, na medida em que a racionalidade para Habermas é um processo dialógico, uma interação de subjetividades mediada pela linguagem. Trata-se, como esclarece o filósofo, de uma "libertação da perspectiva egocêntrica". A liberdade reflexiva é entendida, então, como uma consequência da “interiorização da perspectiva que outros participantes da argumentação têm diante de mim”.

O exercício do razão é, sobretudo, um exercício de alteridade, o qual é transposto para o ambiente democrático, a esfera pública. O estado assume a tarefa de tornar viável o diálogo e a interação entre as subjetividades, através da instituição de procedimentos que garantam a inclusão pelo direito de participação generalizado. Assim como na atitude

${ }^{410}$ HABERMAS, Jürgen. Verdade e Justificação: Ensaios Filosóficos, tradução de Milton Mota. São Paulo: Loyola, 2004, pg. 8.

${ }^{411}$ HABERMAS, Jürgen. Ibidem, pg. 103.

${ }^{412}$ HABERMAS, Jürgen. Op. cit. 
reflexiva do teórico, na democracia é preciso "colocar-se no lugar de" como uma postura prévia a qualquer discurso.

O "colocar-se no lugar de" é uma atitude argumentativa que possibilita o agir racional, no sentido da busca das melhores razões. A adesão racional é aquela que se funda no assentimento, na concordância, isto é, no consenso, a partir da "apropriação" da perspectiva do meu interlocutor. Por isso afirma Habermas que na reflexão da pessoa racional, que toma distância de si mesma, reflete-se, de modo geral, a racionalidade inerente à estrutura e ao procedimento da argumentação ${ }^{413}$.

Dentro da perspectiva habermasiana, o reconhecimento intersubjetivo é fundamental para que a pretensão de validade de uma norma se sustente. No embate discursivo, os envolvidos podem assumir, a cada vez, os papeis de falante e de ouvinte. É essa "distribuição" de papéis que está no cerne da racionalidade comunicativa. É igualmente essa distribuição que assegura o restabelecimento dos vínculos de solidariedade. Conforme esclarece Repa, tem-se que:

\begin{abstract}
A teoria da ação comunicativa é uma tentativa de explicar como é possível o fenômeno social da integração, da coordenação dos planos de ação de vários autores. A ação comunicativa é aquele tipo de interação social em que o meio de coordenação os diversos planos de ação das pessoas envolvidas é dado na forma de um acordo racional, de um entendimento entre as partes, obtido através da linguagem ${ }^{414}$.
\end{abstract}

Ao transpor a lógica da racionalidade comunicativa para o direito, Habermas está buscando apresentar uma proposta de legitimação da ordem jurídica. Isso porque, de acordo com Repa, em Habermas, o aspecto da legitimidade só pode ser desenvolvido adequadamente com base no conceito de autonomia e de democracia, entendida a norma legítima como aquela norma originada de procedimentos discursivos presentes nos âmbitos da legislação assim como da esfera pública em geral $^{415}$.

No capítulo seguinte, será apresentada a teoria habermasiana sobre o direito, especificamente no que tange ao discurso de fundamentação das normas jurídicas e de sua importância para a democracia. Segundo o filósofo alemão, a modernidade, uma vez consciente de suas contingências, cada vez mais fica dependente de uma razão

\footnotetext{
${ }^{413}$ HABERMAS, Jürgen. Ibidem, pg. 103.

${ }^{414}$ REPA, Luiz Sérgio. Direito e Teoria da Ação Comunicativa . In: NOBRE, Marcos; TERRA, Ricardo (orgs.). Direito e Democracia: Um Guia de Leitura de Habermas. São Paulo: Malheiros, 2008, pg. 57.

415 REPA, Luiz Sérgio. Ibidem, pg. 64
} 
procedimental, isto é, de uma razão que conduz um processo contra si mesma ${ }^{416}$, que submete $\mathrm{o}$ argumento à prova do outro.

A associação entre estado de direito e democracia para o pensamento habermasiano é necessária: numa época de política inteiramente secularizada, não se pode ter nem manter um Estado de direito sem democracia radical ${ }^{417}$. Desse modo, propondo uma teoria reconstrutiva da sociedade, Habermas apresenta o direito como um instrumento de mediação capaz de canalizar as tensões sociais e as distintas expectativas normativas através dos procedimentos democráticos.

Segundo o alemão, como explicar a possibilidade de reprodução da sociedade num solo tão frágil como é o das pretensões de validade transcendentes? Por meio do direito, que se apresenta como um médium capaz de criar associações de membros orientados para alcançar um acordo racionalmente motivado ${ }^{418}$. Esse argumento da teoria habermasiana, que será utilizado como ponto de sustentação da teoria democrática sobre o poder constituinte, é o que se explica no capítulo que segue.

${ }^{416}$ HABERMAS, Jürgen. Direito e Democracia: entre facticidade e validade, v. I, tradução de Beno Siebeneichler, $2^{\mathrm{a}}$ edição. Rio de Janeiro: Tempo Brasileiro, 2012, pg. 12.

${ }^{417}$ HABERMAS, Jürgen. Ibidem, pg. 13.

${ }^{418}$ HABERMAS, Jürgen. Ibidem, pg. 25. 


\section{DIREITO E DEMOCRACIA EM HABERMAS: A LEGITIMAÇÃO DO DIREITO POSITIVO PELO CONSENSO}

Conforme a interpretação de Neves, a proposta habermasiana para o Direito parte do postulado de sua autonomia, no sentido de que o direito não é concebido como sistema funcional, que se auto-regula e autolegitima; ele precisa ser fundamentado em um procedimento racional $^{419}$. Sua teoria representa, assim, um resgate da problemática da fundamentação, no sentido de que, para Habermas, uma reaproximação entre moral e direito se apresenta não só como desejável, mas necessária.

Isso se deve ao fato de que a normatividade refere-se à validade e, portanto, exige fundamentação moral ou, mais abrangentemente, fundamentação discursiva do direito ${ }^{420}$. A "força civilizatória" atribuída ao direito por Habermas parte justamente de sua capacidade de transformar postulados normativos não exigíveis coercitivamente em imperativos jurídicos, vinculantes à toda coletividade. Nesse ponto, analisando especificamente a positividade dos direitos humanos, Habermas afirma que tais direitos circunscrevem precisamente a parte de uma moral esclarecida que pode ser traduzida no medium do direito coercitivido e ter realidade política efetiva na robusta configuração de direitos fundamentais efetivos ${ }^{421}$.

A dignidade humana, entendida como a fonte moral de todos os demais direitos fundamentais, é justamente o portal através dos quais os demais postulados morais podem ser transmutados em postulados jurídicos, tornando-se parte do direito positivo e, assim, estando submetidos à coercitividade própria do direito. O respeito à dignidade - e, indiretamente, a todos os demais direitos fundamentais - é o que preserva o espaço de autonomia alcançado pelo estado de direito, que estaria severamente ameaçado pela submissão do poder estatal à economia e à técnica.

\footnotetext{
419 NEVES, Marcelo. Do consenso ao dissenso: O Estado democrático de direito a partir e além de Habermas. In: SOUZA, Jessé (org.). Democracia Hoje: Novos Desafios para a Teoria Democrática Contemporânea. Brasília: Editora UnB, 2001, pg. 112.

${ }^{420}$ NEVES, Marcelo. Ibidem, pg. 115.

${ }^{421}$ HABERMAS, Jürgen. $O$ conceito de dignidade humana e a utopia realista dos direitos humanos. In: HABERMAS, Jürgen. Sobre a Constituição da Europa. São Paulo: Editora Unesp, 2012, pg. 17.
} 
Habermas quer demonstrar, com sua teoria, que a figura pós-tradicional de uma moral orientada por princípios depende de uma complementação através do direito positivo $^{422}$. Como, então, sustentar que pretensões de validade transcendentes, que legitimariam o direito positivo e, por consequência, toda a ordem democrática, possam ser reproduzidas objetivamente em uma sociedade marcada pela complexidade e pela destruição da moral tradicional, homogênea e compartilhada? Conforme as palavras do filósofo alemão:

\begin{abstract}
O medium do direito apresenta-se como um candidato para ta explicação, especialmente na figura moderna do direito positivo. As normas desse direito possibilitam comunidades extremamente artificais, mais precisamente, associações de membros livres e iguais, cuja coesão resulta simultaneamente da ameaça de sanções externas e da suposição de um acordo racionalmente motivado ${ }^{423}$.
\end{abstract}

Reconhece-se, assim, que o Direito assume um papel relevante no resgate dos vínculos de solidariedade social indispensáveis à perpetuação do estado de direito e da garantia do espaço de autonomia privada.

Para Habermas, uma reconstrução da teoria do direito só é possível pela transformação do conceito de linguagem e de sua função no processo de construção do conhecimento, e, por conseguinte, do próprio mundo. O autor "lembra" que a relação entre facticidade e validade, delineada na tradição platônica, se modifica quando a linguagem passa a ser considerada como um medium universal de incorporação da razão ${ }^{424}$.

O caminho da fundamentação do direito positivo e do resgate de sua legitimidade está, assim, ligado de forma indissociável à teoria do discurso e à compreensão de validade normativa como o resultado de um procedimento orientado para o assentimento racional. Habermas funda sua proposta teórica em uma teoria consensual da verdade, de modo que $a$ condição de verdade das sentenças é o acordo potencial de todos os outros ${ }^{425}$. Por esse motivo é que se buscou, no capítulo III, demonstrar a relevância da virada linguística para o nascimento da teoria habermasiana e para o remodelamento da teoria jurídica como todo.

$\mathrm{O}$ argumento habermasiano parte então, do encadeamento das constatações já explicitadas nos capítulos anteriores, fundadas na percepção do novo papel da linguagem

\footnotetext{
${ }^{422}$ HABERMAS, Jürgen. Ibidem, pg. 23.

${ }^{423}$ HABERMAS, Jürgen. Ibidem, pg. 25.

${ }^{424}$ HABERMAS, Jürgen. Op. cit.

425 OLIVEIRA, Manfredo de A. A reviravolta linguistico-pragmática na filosofia contemporânea, $3^{\text {a }}$ edição. São Paulo: Loyola, 206, pg. 310.
} 
no paradigma de racionalidade. Em primeiro lugar, tem-se a compreensão de que a racionalidade instrumental não é capaz de oferecer uma saída satisfatória para o problema moral resultante da destruição da moral tradicional: como salientou Apel, nunca se precisou tanto de uma orientação ética universal, ao mesmo tempo em que nunca se esteve tão distante da possibilidade de tal orientação. Em segundo lugar, Habermas reconhece que é na democracia que a preservação do espaço de autonomia conquistada com a revolução liberal se faz possível, na medida em que a relação de reconhecimento recíproco institucionalizada na esfera pública é o que sustenta, com base na dignidade humana, a autonomia de cada um a partir da autonomia do grupo, organizado democraticamente.

Nos itens seguintes, será feita uma leitura dos principais postulados da teoria de Habermas para o direito, que parte de tais constatações e busca oferecer uma saída que seja capaz de congregar: a reaproximação do direito e da moral; a legitimação da ordem jurídica pelo procedimento democrático; a institucionalização da razão dialogal com base no consenso.

\subsection{A Complementaridade entre Direito e Moral}

Para Habermas, o direito positivo apresenta um déficit de legitimidade, consequência do abismo criado pela teoria jurídica entre direito natural e direito positivo, e que representa, na verdade, um abismo entre direito e moral. Para o autor, essa distinção não se mostra plausível, seja do ponto de vista sociológico, seja normativo. Uma releitura dessa dicotomia se mostra necessária, a fim de resgatar a carga axiológica perdida pelo direito positivo.

Tendo em vista a falência da eticidade tradicional após o advento do Estado moderno, Habermas reconhece que normas jurídicas e normas morais constituiem dois tipos diferentes de normas de ação, que surgem lado a lado, completando-se $e^{426}$, e que se diferenciam das normas típicas da eticidade tradicional. Conforme esclarece Neves,

Em Habermas, moral e direito referem-se aos mesmos problemas: a regulação legítima de relação interpessoais, a coordenação de ações mediante normas justificadas e a solução consensual de conflitos com

\footnotetext{
${ }^{426}$ HABERMAS, Jürgen. Direito e Democracia: entre facticidade e validade, v. I, $2^{\text {a }}$ edição, tradução de
} Flávio Siebeneichler. Rio de Janeiro: Tempo Brasileiro, 2012, pg. 139. 
base em princípios normativos e regras reconhecidas intersubjetivamente. Entretanto, a moral pós-tradicional constitui apenas uma forma do saber cultural, enquanto o direito simultaneamente tem força vinculante no plano institucional $^{427}$.

Buscando uma reaproximação, Habermas propõe uma visão de direito que pressupõe uma fundamentação moral e ético-política. $\mathrm{O}$ direito, buscando realizar a ideia de dignidade, precisa de uma "carga moral", que se manifesta no discurso de fundamentação normativa.

A fim de demonstrar a relação de complementaridade existente entre normas morais e normas jurídicas, Habermas resgata a filosofia prática de Kant e seu conceito de autonomia. Enquanto que as normas morais se caracterizam por sua dependência da consciência livre do sujeito, no sentido de que o agir moral é, antes de tudo, um agir pela norma, um agir motivado unicamente pelo reconhecimento subjetivo de sua validade universal $^{428}$, o agir jurídico, em contrapartida, é dependente da relação externa entre sujeitos livres, condicionada pelo termor da sanção (ou autorização para a coerção) ${ }^{429}$.

De acordo com Kant, a boa vontade não é boa por aquilo que promove ou realiza, pela aptidão para alcançar qualquer finalidade proposta, mas tão-somente pelo querer [...]. Trata-se de uma proposta de moralidade não consequencialista, que deriva a autonomia do indivíduo justamente de sua capacidade de julgar o bom por si mesmo, decidindo se agirá pela norma ou não (conforme Kant, a razão nos foi dada como faculdade prática, isto é, como faculdade que deve exercer influência sobre a vontade ${ }^{430}$ ).

Apesar de resgatar a filosofia moral kantiana, Habermas recomenda cautela, a fim de que se evite a ideia de que a moral tem a ver apenas com relações sociais que caem sob a reponsabilidade pessoal. Isso porque só se pode levar a sério o "sentido universalista das regras morais" quando tais normas são transpostas para uma prática pública, simbolizada pelo direito. Diz o autor alemão:

[...] uma divisão regional entre as competências da moral e do direito de acordo com domínios de ação públicos e privados não faz sentido, uma vez que a formação da vontade do legislador político se estende também aos aspectos morais da matéria a ser regulamentada. Em sociedades

\footnotetext{
${ }^{427}$ NEVES, Marcelo. Ibidem, pg. 121.

${ }^{428}$ Segundo as palavras de Kant, tem-se que: "Pois que aquilo que deve ser moralmente bom não basta que seja conforme à lei moral, mas tem também que cumpir-se por amor dessa mesma lei [...]”. KANT, Immanuel. Fundamentação da Metafísica dos Costumes, tradução de Paulo Quintela. Lisboa: Edições 70, 2008, pg. 16.

${ }^{429}$ HABERMAS, Jürgen. Ibidem, pg. 140.

${ }^{430}$ KANT, Immanuel. Ibidem, pg. 25.
} 
complexas, a moral só obtém efetividade em domínios vizinhos, quando é traduzida para o código do direito ${ }^{431}$.

Conforme o entendimento de Habermas, a "legislação moral" reflete-se na jurídica, na medida em que uma ordem jurídica só pode ser legítima quando não contrariar princípios morais $^{432}$. Não se trata de uma hierarquização do direito à moral, mas da criação de uma relação de complementação recíproca existente por conta exigência de legitimação do direito ${ }^{433}$.

Enquanto que na sociedade tradicional direito e moral estavam entrelaçados, na sociedade complexa da modernidade observa-se um processo de diferenciação. Apesar de se referirem aos mesmos problemas (como é possível ordenar legitimamente relações interpessoais e coordenar enre si ações servindo-se de normas justificadas?), as normas jurídicas e as morais o fazem a partir de diferentes ângulos, tendo o direito a característica fundamental de adquirir obrigatoriedade também no nível institucional ${ }^{434}$.

A moral participa do processo de fundamentação do direito, na medida em que uma parte das normas de ação positivadas encontra sua exigibilidade institucional na demonstração racional de sua validade universal no plano moral. Apesar disso, a fundamentação do direito não se esgota na moralidade, razão pela qual, embora complementares, não podem as duas instâncias normatividade - moral e direito - se confundir.

Conforme esclarece Habermas:

O princípio da democracia resulta de uma especificação correspondente para tais normas de ação que surgem na forma do direito e que podem ser justificadas com o auxílio de argumentos pragmáticos, ético-políticos e morais - e não apenas com o auxílio de argumentos morais ${ }^{435}$.

Assim, percebe-se que o direito positivo depende do princípio da democracia para justificação de suas normas, não apenas para demonstração dos argumentos morais, mas igualmente para que os argumentos pragmáticos e ético-políticos possam ser canalizados da esfera pública para a ordem positivada.

Para o filósofo alemão, tanto as normas morais como as normas jurídicas podem ser julgadas imparcialmente e decididas racionalmente, utilizando-se como mecanismo de

\footnotetext{
${ }^{431}$ HABERMAS, Jürgen. Ibidem, pg. 145.

${ }^{432}$ HABERMAS, Jürgen. Ibidem, pg. 140.

${ }^{433}$ HABERMAS, Jürgen. Ibidem, pg. 141.

${ }^{434}$ HABERMAS, Jürgen. Op. cit. .

${ }^{435}$ HABERMAS, Jürgen. Ibidem, pg. 143.
} 
fundamentação o principio do discurso. Habermas esclarece que não há uma distinção satisfatória entre princípio moral e princípio do discurso, estando este pressuposto nas relações de reconhecimento recíproco presentes nas formas de vida estruturadas conforme o modelo comunicativo ${ }^{436}$.

\subsection{Princípio Moral e Princípio Democrático: Legitimidade e o Sistema de}

\section{Direitos}

De acordo com o entendimento de Habermas, o direito só será validade quando estruturado democraticamente, na medida em que somente podem pretender validade legítima as leis jurídicas capazes de encontrar o assentimento de todos os parceiros do direito, num processo jurídico de normatização discursiva ${ }^{437}$.

O princípio democrático é que viabiliza, portanto, a fundamentação racional das normas jurídicas, que passam a ser não só válidas, como legítimas. Não estando no mesmo nível do princípio moral, o princípio da democracia pressupõe preliminarmente a possibilidade da decisão racional das questões práticas ${ }^{438}$, no sentido de que o princípio da democracia simplesmente orienta a institucionalização do processo de formação política vontade racional.

O princípio da democracia nada mais é que o princípio do discurso transformado pela institucionalização jurídica, que passa a conferir força legitimadora ao processo de normatização. Nesse sentido,

Eu vejo esse entrelaçamento [entre o princípio do discurso e a forma jurídica] como uma gênese lógica de direitos, a qual pode ser reconstruída passo a passo. Ela começa com a aplicação do princípio do discurso ao direito a liberdades subjetivas de ação em geral - constitutivo para forma jurídica enquanto tal - e termina quando acontece a institucionalização jurídica de condições para um exercício discursivo da autonomia política, a qual pode equipar retroativamente a autonomia privada, inicialmente abstrata, com a forma jurídica ${ }^{439}$.

\footnotetext{
${ }^{436}$ HABERMAS, Jürgen. $O p$. cit.

${ }^{437}$ HABERMAS, Jürgen. Ibidem, pg. 145.

${ }^{438}$ HABERMAS, Jürgen. Op. cit.

${ }^{439}$ HABERMAS, Jürgen. Ibidem, pg. 158.
} 
Por essa razão, afirma Habermas ser o princípio da democracia o verdadeiro núcleo de um sistema de direitos. Esse núcleo contém uma série de direitos considerados necessários sempre que os sujeitos pretendam regular sua convivência de forma legítima, a partir do direito positivo. A ordem só é legítima, assim, quando originariamente já contempla determinados direitos tomados reciprocamente entre os diversos sujeitos participantes da esfera pública.

Tratam-se tais direitos de condições da formalização jurídica, e existem mesmo antes de qualquer organização objetiva ou jurídica de um poder do Estado ${ }^{440}$. Seriam eles: a) direito à maior medida possível de iguais liberdades subjetivas de ação; b) direitos à possibilidade de postulação judicial de direitos; c) direitos resultantes da condição de status de membro de uma associação de parceiros de direitos; d) direitos à participação, em igualdade de chances, em processos de formação da opinião e da vontade pública; e) direitos a condições de vida garantias social, técnica e ecologicamente ${ }^{441}$.

A compreensão de cada uma dessas categorias de direitos "apriorísticos" é fundamental para o argumento de que o poder constituinte, moldado à luz da teoria clássica, precisa de uma releitura, a fim de que sejam revistas as características que o definem como poder ilimitado e incondicionado. Se, como Habermas pretende, existem direitos "antes" do Estado, deduzidos de um princípio do discurso que orienta a elaboração racional e legítima da ordem jurídica, o poder constituinte precisa ser exercido sob a orientação de tais direitos, transformando-os em direito positivo por meio da elaboração da carta constitucional.

Os procedimentos constitucionais precisam, portanto, ser organizados de modo a que tais direitos façam parte da estrutura do Estado, permitindo que os diversos sujeitos constitucionais possam participar do processo de formação da vontade política em igualdade de condições. Analisam-se, nos itens seguintes, as categorias expostas por Habermas e sua importância para a institucionalização do princípio democrático.

\footnotetext{
${ }^{440}$ HABERMAS, Jürgen. Ibidem, pg. 159.

${ }^{441}$ HABERMAS, Jürgen. Op. cit.
} 


\subsubsection{Direito à maior medida possível de iguais liberdades subjetivas de ação}

O direito em referência se funda no pressuposto básico de qualquer ordem democrática: o reconhecimento recíproco da igualdade de direitos entre os participantes da esfera pública. Enquanto membros de uma comunidade política comprometida com a legitimação racional da ordem jurídica, os sujeitos precisam "distribuir" as liberdades de ação de modo a que haja uma relação de simetria entre os indivíduos.

Há de haver, assim, uma compatibilidade entre os espaços de autonomia individual, de modo a que a liberdade de participação não seja obstruída pela desigualdade das possibilidades de ação dos sujeitos.

Mencionando Kant e o seu princípio do direito, Habermas afirma:

O princípio do direito kantiano equivale a esse direito geral implicando liberdades iguais; pois ele afirma apenas que um código de direito deve ser organizado na figura de direitos subjetivos, legitimamente distribuídos, os quais garantem proteção da autonomia privada de sujeitos de direitos ${ }^{442}$.

Por essa razão, não pode haver democracia sem que se garanta o postulado da igualdade, que se reflete não apenas em inclusão generalizada nos processos políticos de deliberação, mas, sobretudo, no âmbito privado, na garantia de liberdades de ação subjetivas iguais.

\subsubsection{Direitos à postulação judicial de direitos}

Embora a postulação judicial já dependa do estabelecimento de uma organização estatal capaz de conduzir o procedimento, Habermas entende que, em qualquer sociedade preocupada com a legitimação da ordem, há de haver garantias processuais que permitam aos indivíduos postular suas pretensões perante um tribunal independente, em condições de

${ }^{442}$ HABERMAS, Jürgen. Ibidem, pg. 160. 
igualdade, tais como a garantia de proibição de julgamentos por tribunais de exceção e a garantia do princípio do juiz natural ${ }^{443}$. Esclarece Habermas que:

Pessoas de direito só podem mobilizar as autorizações ao uso da força, acopladas aos seus direitos, se tiverem livre acesso a tribunais independentes e efetivos, que decidem autoritária e imparcialmente os casos de disputa no quadro das leis. À luz do princípio do discurso, é possível fundamentar direitos elementares da justiça, que garantem a todas as pessoas igual proteção jurídica, igual pretensão a ser ouvido, igualdade da aplicação do direito, portanto o direito a serem tratadas como iguais perante a lei etc ${ }^{444}$.

Trata-se do reconhecimento do status normativo diferenciado à cláusula do devido processo legal, que congrega em si todas as garantias processuais que asseguram o transcurso organizado e justo dos procedimentos judiciais. A existência de instituições permanentes capazes de atuar mediante procedimentos organizados em contraditório é, portanto, não uma consequência do modelo democrático, mas uma condição prévia de sua existência.

Para Néry, as garantias processuais especificadas na constituição federal brasileira constituem, em verdade, manifestações normativas do devido processo legal, que, por sua vez, nada mais é do que a possibilidade efetiva de a parte ter acesso à justiça, deduzindo pretensão e defendendo-se de modo mais amplo possivvel, isto é, de ter his day in Court, na denominação genérica da Suprema Corte dos Estados Unidos ${ }^{445}$. Percebe-se, assim, que mesmo a doutrina processualista já contempla a relação necessária entre a organização democrática, o princípio universal de justiça e o devido processo.

Cappelletti e Garth, por sua vez, entendem que o acesso à justiça busca realizar duas finalidades básicas do sistema jurídico, entendido como sistema pelo qual as pessoas podem reivindicar seus direitos elou resolver seus litígios sob os auspícios do Estado. São elas: primeiro, o sistema deve ser igualmente acessivel a todos; segundo, ele deve produzir resultados que sejam individual e socialmente justos ${ }^{446}$.

Por essa razão, o direito ao acesso à justiça, juntamente com a cláusula do devido processo legal, embora se tornem objetivamente exigíveis como direitos fundamentais positivados na ordem jurídica com o nascimento do Estado pela constituição, são prévios,

\footnotetext{
${ }^{443}$ HABERMAS, Jürgen. Ibidem, pg. 163.

${ }^{444}$ HABERMAS, Jürgen. Ibidem, pg. 162.

${ }^{445}$ NÉRY JÚNIOR, Nelson. Princípios do processo civil na Constituição Federal, $7^{\mathrm{a}}$ edição. São Paulo: RT, 2002, pg. 42.

${ }^{446}$ CAPPELLETTI, Mauro; GARTH, Bryant. Acesso à Justiça, tradução de Ellen Gracie Northfleet. Porto Alegre: SAFE, 1988, pg, 8.
} 
anteriores à ordem estatal, como condições de legitimação do Direito e do exercício do poder político. A constituição precisa contemplá-los porque, como esclarece Habermas, não existe nenhum direito legítimo sem esses direitos ${ }^{447}$.

\subsubsection{Direitos decorrentes do status de membro de uma sociedade política}

Para Habermas, o direito - contrariamente à moral - regulam contextos interacionais de uma sociedade concreta. Trata-se de uma manifestação da faticidade própria à realidade jurídica, no sentido de que a origem do direito são as decisões de um legislador histórico, referindo-se a um universo jurídico geograficamente delimitada e a uma coletividade de parceiros jurídicos delimitável socialmente ${ }^{448}$.

Ao contrário da moral, que não pode ser delimitada espacial e temporalmente em sua universalidade abstrata, o direito representa uma construção cultural de um povo. A moral, quando se fundamenta racionalmente, regula possíveis interações entre sujeitos capazes de falar e agir em geral, independentemente de sua pertença a qualquer estado. Conforme o alemão, tem-se que:

\footnotetext{
Tais limitações no tempo histórico e no espaço social são devidas à circunstâncias de que os sujeitos do direito têm de ceder os seus direitos de usar a força a uma instância que monopoliza os meios legítimos de coerção e, dado o caso, os emprega a seu favor. Pois todo o monopólio da força sobre a terra é uma entidade finita, o que equivaleria inclusive para um governo mundial - em relação ao futuro e ao cosmo, ela é provinciana $^{449}$.
}

Segundo o filósofo, tais direitos assumem a forma de direitos de participação no estado $^{450}$. São direitos próprios da cidadania, que o sujeito deve titularizar para ser incluído, com segurança, na comunidade política concreta, permitindo-se, a partir de tais direitos, diferenciar-se o cidadão do estrangeiro, o membro do não-membro. Na qualidade de cidadão nacional, ao titularizar tais direitos, o sujeito se habilita a participar da esfera pública, podendo ser integrado aos processos de formação da vontade e da opinião política.

\footnotetext{
${ }^{447}$ HABERMAS, Jürgen. $O p$. cit.

${ }^{448}$ HABERMAS, Jürgen. Ibidem, pg. 161.

${ }^{449}$ HABERMAS, Jürgen. Op. cit.

${ }^{450}$ HABERMAS, Jürgen. Op. cit.
} 
São os direitos que definem a pertença do indivíduo ao estado nacional. Pretensões como o direito de asilo e a proibição da extradição de nacionais integram tal categoria de direitos, que implicam a concretização do status geral de um membro numa associação livres de parceiros do direito.

\subsubsection{Direitos à participação no processo de formação da vontade política}

É fundamental, para o direito ser considerado legítimo, que os destinatários das normas jurídicas sejam, também, os seus autores, através de um processo de autolegislação autônoma e consciente. Habermas pontua que, enquanto sujeitos de direitos, eles só conseguirão autonomia se se entenderem e agirem como autores dos direitos aos quais desejam submeter-se como destinatários ${ }^{451}$.

É esclarecedora a passagem de Habermas:

A ideia da autolegislação tem que adquirir por si mesma validade no medium do direito. Por isso, têm que ser garantidas pelo direito as condições sob as quais os cidadãos podem avaliar, à luz do princípio do discurso, se o direito que estão criando é legítimo. Para isso servem os direitos fundamentais legítimos à participação nos processos de formação da opinião e da vontade do legislador ${ }^{452}$.

Assim, reconhece-se a importância do direito de participação, que permite a verificabilidade das normas produzidas no estado por aqueles que serão os destinatários. A autonomia, assim, é vislumbrada na condição simultânea assumida pelo sujeito democrático: de legislador e de receptor dos mandamentos do direito legislado.

$\mathrm{Na}$ medida em que o princípio do discurso exige o assentimento de todos os potencialmente atingidos como condição de validade das normas jurídicas, é indispensável que se garanta a participação em todos os processos de deliberação e de decisão relevantes para a legislação, de modo a que a liberdade comunicativa de cada um possa vir simetricamente à tona, ou seja, a liberdade de tomar posição em relação a pretensões de validade criticáveis ${ }^{453}$.

\footnotetext{
${ }^{451}$ HABERMAS, Jürgen. Ibidem, pg. 163.

${ }^{452}$ HABERMAS, Jürgen. Op. cit.

${ }^{453}$ HABERMAS, Jürgen. Ibidem, pg. 164.
} 
Habermas entende que, ao explicitar tais categorias de direitos "apriorísticos", direitos que existem antes mesmo da organização do estado, é possível explicar o postulado da cooriginariedade da autonomia política e da privada, no sentido de compatibilizar a soberania do povo com a proteção dos direitos humanos. Nesse sentido, só é possível assegurar a preservação de uma sociedade que se autolegisla soberanamente quando tais direitos e liberdades são garantidos aos sujeitos.

Por essa razão, se reconhece que tais direitos são condições necessárias que apenas possibilitam o exercício da autonomia política, não restringindo, assim, a soberania do legislador. São "condições possibilitadoras" que não impõem limitações àquilo que constituem $^{454}$.

Habermas não se arrisca a fazer uma enumeração exaustiva dos direitos fundamentais, pois reconhece que, por meio do processo de positivação, quando são produzidas as constituições estatais concretas, há uma leitura "contextual" do sistema de direitos. Não é papel da teoria, mas dos sujeitos constituintes, o uso da autonomia política que permite a definição concreta do rol de direitos e liberdades fundamentais. Esse argumento se sustenta na medida em que tais direitos não se apresentam como postulados de um direito natural, mas são intepretações de sujeitos historicamente situados. Tais sujeitos, ao lerem o sistema de direitos pelo ângulo de sua situação, [...] apenas explicitam o sentido do empreendimento ao qual eles já se dedicaram, ao decidirem regulamentar legitimamente sua convivência através do direito ${ }^{455}$.

Desse modo, é possível encontrar rol de direitos fundamentais distintos em realidades constitucionais diversas, na medida em que a "interpretação contextual" do sistema de direitos depende da realidade cultural e das expectativas normativas de cada sociedade específica. Reconhece-se, assim, que a enumeração dos direitos da pessoa constitui uma manifestação da soberania do povo, que decidirá, à luz de suas necessidades, os direitos básicos de que necessita para instaurar a ordem constitucional e estabilizá-la.

Conforme o filósofo alemão,

[...] a fundamentação do sistema dos direitos pela via da teoria do discurso esclarece o nexo interno que existe entre autonomia privada e pública. O direito não consegue o seu sentido normativo plano per se através de sua forma, ou através de um conteúdo moral dado a priori, mas

\footnotetext{
${ }^{454}$ HABERMAS, Jürgen. Ibidem, pg. 165.
}

${ }^{455}$ HABERMAS, Jürgen. Op. cit. 
através de um procedimento que instaura o direito, gerando legitimidade ${ }^{456}$. (grifos do autor)

Entre os componentes do "sistema de direitos" proposto por Habermas, parece ser o direito à participação no processo de formação da vontade e da opinião política aquele que congrega todos os demais, pois sem a participação livre nos procedimentos democráticos nenhum dos demais direitos pode ser sequer positivado. Esse é o sentido da “cooriginariedade" entre autonomia pública e privada - só se é capaz de resguardar uma esfera eminentemente privada de ação se tal âmbito for construído através da participação na esfera pública.

\subsubsection{Direitos a condições de vida garantidas social, técnica e ecologicamente}

Habermas entende que os direitos fundamentais a condições de vida garantidas social, técnica e ecologicamente são implicações das demais categorias de direitos, $n a$ medida em que isso for necessário para um aproveitamento, em igualdade de chances, dos direitos de liberdade e de participação ${ }^{457}$.

Ao contrário do que faz em relação às quatro categorias já elencadas, Habermas não cuida de apresentar exemplos ou mesmo explicar com detalhes a importância dos direitos a condições de vida digna. Tais direitos podem ser identificados como os direitos fundamentais de segunda geração, ou simplesmente direitos sociais, que se apresentam em sua exigibilidade com o advento do estado do bem-estar, já na primeira metade do século XX.

Tratam-se dos direitos à saúde, à educação, à previdência social, ao trabalho, ao lazer, etc. Direitos que buscam corrigir a exclusão de uma parcela considerável de sujeitos pobres no gozo dos serviços sociais mais básicos, a fim de evitar que a desigualdade de condições econômicas represente um déficit na dignidade por força da exclusão social. Nesse sentido, é impensável uma esfera de autonomia privada sem o acesso a prestações sociais que instrumentalizam o exercício da liberdade individual.

\footnotetext{
${ }^{456}$ HABERMAS, Jürgen. Ibidem, pg. 172.

${ }^{457}$ HABERMAS, Jürgen. Ibidem, pg. 160.
} 
Os direitos a condições de vida digna parecem especialmente importantes em democracias recentes dos países em situação de subdesenvolvimento, como o Brasil, nos quais a desigualdade socioeconômica é uma característica marcante da esfera pública. Para que a participação nos processos de deliberação não reste prejudicada pelo desnivelamento dos espaços de autonomia individual real, mostra-se necessária a garantia de acesso a prestações inclusivas que permitam uma melhor distribuição dos serviços sociais, como educação e saúde, por exemplo.

O economista indiano Amartya Sen apresenta uma interpretação acerca das teorias do desenvolvimento e acerca dos efeitos da pobreza sobre a liberdade que pode ser elucidativa para a compreensão da categoria dos direitos à vida digna, exposta por Habermas, e sua relação com a autonomia individual e a democracia. Sen chama atenção para uma transformação do conceito de desenvolvimento humano, que deve levar em consideração não a acumulação da riqueza total por país, mas a distribuição dos espaços de liberdade entre os cidadãos. Para Sen, o desenvolvimento pode ser visto como um processo de expansão das liberdades reais que as pessoas desfrutam ${ }^{458}$.

\title{
Esclarece Sen:
}

\begin{abstract}
A ligação entre liberdade individual e realização de desenvolvimento social vai muito além da relação constitutiva - por mais importante que ela seja. $O$ que as pessoas conseguem positivamente realizar é influenciado por oportunidades econômicas, liberdades políticas, poderes sociais e por condições habilitadoras como boa saúde, educação básica e incentivo e aperfeiçoamento de iniciativas ${ }^{459}$.
\end{abstract}

O economista salienta a existência de inter-relações entre a liberdade para participar da escolha social e da tomada de decisões públicas e a liberdade provocada pelo gozo de tais "condições habilitadoras" como a boa saúde e a educação básica. Isso porque as liberdades não são apenas os fins primordiais do desenvolvimento, mas também os meios principais $^{460}$. Em outras palavras, sem um mínimo de autonomia privada de início não é possível sequer pretender chegar ao desenvolvimento social e econômico.

A contribuição de Sen permite concluir que a privação de oportunidades simbolizada pela negação aos meios dignos de vida - interfere não apenas no

\footnotetext{
${ }^{458}$ SEN, Amartya. Desenvolvimento como liberdade, tradução de Laura Motta. São Paulo: Cia das Letras, 2000, pg. 19.

${ }^{459}$ SEN, Amartya. Ibidem, pg. 19.

${ }^{460}$ SEN, Amartya. Ibidem, pg. 25.
} 
desenvolvimento individual do sujeito, mas, sobretudo, no desenvolvimento do grupo, já que a liberdade de participação na vida pública também resta severamente prejudicada. Para o economista, expandir as liberdades que temos também permite que sejamos seres sociais mais completos, pondo em prática nossas volições, interagindo com o mundo em que vivemos e influenciando esse mundo ${ }^{461}$.

É possível compreender, com a ajuda da colaboração de Sen, a relevância que as “oportunidades de vida digna”, ou as condições materiais para o exercício da liberdade, representam para o êxito do projeto democrático, a ponto de justificar a inclusão de tal categoria de direitos por Habermas em seu "sistema" básico de direitos, indispensáveis para qualquer sociedade que pretenda legitimidade para a sua ordem jurídica.

Habermas reconhece que tais direitos, embora sejam direitos "antes do estado" (ou in statu nascendi), no sentido de pretensões exigíveis racionalmente, só ganham concretude e efetividade no âmbito do aparato estatal. $\mathrm{O}$ caráter apriorístico de tais direitos reflete, na verdade, seu status de condição de legitimidade da ordem jurídica democrática, isto é, eles devem estar presentes quando se pretenda a validade racional do direito legislado. Tratam-se, assim, de pressupostos nos quais os membros de uma comunidade jurídica moderna se apoiam quando pretendem legitimidade, sem apelar para motivos de ordem religiosa ou metafisica ${ }^{462}$.

A análise do sistema de direitos habermasiano permite uma releitura da teoria clássica do poder constituinte na medida em que reconhece a existência de limites materiais ao processo de elaboração da carta constitucional. Este argumento será desenvolvido com mais detalhes no capítulo seguinte, dedicado exclusivamente à teoria do poder constituinte democrático.

A autonomia privada garantida pelo sistema de direitos depende da institucionalização pelo estado. Por esse motivo, Habermas cuida de reconstruir o processo de formação da vontade e da opinião pública, a fim de compreender de que modo os elementos morais, ético-políticos e estratégicos influenciam o embate discursivo na esfera pública. Essa "reconstrução" será analisada no item seguinte.

\footnotetext{
${ }^{461}$ SEN, Amartya. Ibidem, pg. 29.

${ }^{462}$ HABERMAS, Jürgen. Ibidem, pg. 169.
} 


\subsection{O Conceito de Esfera Pública}

A teoria habermasiana propõe um modelo normativo de democracia deliberativa, fundado no princípio do discurso e na razão comunicativa. O filósofo alemão parte de pressupostos pragmáticos teoricamente inevitáveis e orienta a institucionalização da correspondente prática de autodeterminação de pessoas privadas ${ }^{463}$. Desse modo, uma ordem política legítima precisa, simultaneamente, já contemplar determinados direitos que são essenciais à formação autônoma da vontade, além de delimitar e organizar os procedimentos de formação dessa vontade.

Seu objetivo, portanto, é estabelecer uma teoria da democracia, delineada normativamente, cujos conceitos empiristas e cujo olhar objetivador são tomados de empréstimo às ciências sociais ${ }^{464}$. Considerado um modelo ideal da organização política democrática, a proposta habermasiana busca inovar na medida em que congrega elementos da perspectiva liberal e da perspectiva republicana. Enquanto que, na visão liberal, $o$ processo democrático se realiza exclusivamente na forma de compromisso de interesses, para a teoria republicana a formação democrática da vontade realiza-se na forma de um autoentendimento ético-político, onde o conteúdo da deliberação deve ter o respaldo de um consenso entre os sujeitos privados ${ }^{465}$.

Habermas contempla não apenas a formação do consenso racional e eticamente orientado, mas igualmente as negociações que os atores políticos tomados a partir da razão instrumental. $\mathrm{O}$ entrelaçamento de tais perspectivas - a liberal e a republicana - na compreensão do processo de formação da vontade e da opinião pública será analisado no item subsequente, mas o seu entendimento depende da exata compreensão do conceito de esfera pública e da demonstração de sua imprescindibilidade para uma teoria normativa da democracia construída a partir de tais bases.

Habermas apresenta a esfera pública como o espaço público político: o locus de comunicação onde o debate é realizado e o consenso pode ser alcançado. Para o embate discursivo seja possível, é necessária uma organização, uma definição prévia das vias de

${ }^{463}$ HABERMAS, Jürgen. Direito e Democracia: entre facticidade e validade, v. II, $1^{a}$ edição, tradução de Flávio Siebeneichler. Rio de Janeiro: Tempo Brasileiro, 2011, pg. 11.

${ }^{464}$ HABERMAS, Jürgen. Op. cit.

${ }^{465}$ HABERMAS, Jürgen. Ibidem, pg. 19. 
diálogo e de participação de diversos atores sociais, de modo que Habermas a define como uma estrutura comunicacional enraizada no mundo da vida através da sociedade civil $^{466}$.

Não se confundindo com o espaço parlamentar, estatal, marcado pelo formalismo, a esfera pública tem uma dimensão social mais ampla, e funciona como uma "caixa de ressonância" a partir da qual é possível identificar, tematizar e "dramatizar" os problemas identificados pela comunidade de participantes do discurso a fim de tais problemas sejam assumidos e elaborados pelo complexo parlamentar.

A esfera pública, conforme esclarece Habermas, não pode ser confundida com um sistema, já que seus limites são fluidos, "permeáveis e deslocáveis”. Trata-se, na verdade, de uma rede adequada para comunicação de conteúdos, tomadas de posição e opiniões, onde os diversos níveis discursivos podem ser utilizados pelos sujeitos a fim de que se convertam em um consenso, isto é, uma opinião pública, compartilhada. Estando aberta a todos os potenciais parceiros do diálogo, tem-se na esfera pública uma observação mútua, um espaço de situação de fala que, ao ser compartilhado mutuamente, abre-se através das relações interpessoais que nascem no momento em que os participantes tomam posição perante os atos de fala dos outros ${ }^{467}$.

A esfera pública tem, assim, uma importância fundamental para o modelo democrático habermasiano, na medida em que nela se canalizam os conflitos, as tensões e os argumentos manejados pelos indivíduos na busca pelo consenso e pela prevalência do melhor argumento possível. A proposta de uma democracia radical - no sentido de uma participação diária, generalizada e comprometida - almejada por Habermas depende do fortalecimento da esfera pública, isto é, deste âmbito de discussão capaz de "aliviar" o espaço estatal da tarefa de tomar decisões ${ }^{468}$. Conforme esclarece Habermas,

\footnotetext{
Essa circunstância pode ser esclarecida pelo fato de que nenhuma esfera pública pode ser produzida a bel-prazer. Antes de ser assumida por atores que agem estrategicamente, a esfera pública tem que reproduzir-se a partir de si mesma e configurar-se como uma esfera autônoma ${ }^{469}$.
}

Desse modo, uma esfera pública fortalecida permanece com sua fluidez característica, que permite a inclusão não só de sujeitos, mas de argumentos e opiniões, favorecendo a troca comunicativa no espaço público. Assim, tem-se que o "locus" de

\footnotetext{
${ }^{466}$ HABERMAS, Jürgen. Ibidem, pg. 92.

${ }^{467}$ HABERMAS, Jürgen. Ibidem, pg. 93.

${ }^{468}$ HABERMAS, Jürgen. Ibidem, pg. 94.

${ }^{469}$ HABERMAS, Jürgen. Ibidem, pg. 97.
} 
decisão sobre as normas jurídicas não fica restrito exclusivamente no ambiente parlamentar, ou estatal, de modo que o consenso normativo alcançado contou com o assentimento racional de um número maior de participantes do discurso.

A esfera pública é, então, um campo social de que faz parte cada cidadão. Nesse campo, todos se sentem livres para manifestar sua opinião e apresentar seu argumento, uma vez que estão protegidos pela garantia de liberdade de expressão. A transmissão das opiniões e dos atos comunicativos em geral se dá através do auxílio de meios como a imprensa (rádio, televisão, mídias impressas). As opiniões que surgem da esfera pública têm um poder de influência sobre o estado, na medida em que ela atua como "mediadora" entre a sociedade e o estado ${ }^{470}$.

O conceito de esfera pública nasce com os estados nacionais na Modernidade, no século XVIII, a partir do antagonismo que se desenvolve entre sociedade civil e estado. Por essa razão afirma Habermas que a esfera pública burguesa é conceituada como a esfera de homens públicos em concorrência com o estado. Esse espaço de "concorrência" é reclamado pelos próprios cidadãos a fim de que possam "problematizar" as questões de estado, formando uma opinião que atuará de forma decisiva no processo decisório $\operatorname{parlamentar}^{471}$.

Conforme esclarece Thompson,

Entre o domínio da autoridade pública ou Estado, de um lado, e o domínio privado da sociedade civil e da família, de outro, surgiu uma nova esfera do "público": uma esfera pública burguesa integrada por indivíduos privados que se reúnem para debater entre si sobre a regulação da sociedade civil e a administração do Estado; trata-se de uma esfera em que se pode fazer frente às atividades do Estado e de submetê-las à crítica. (tradução livre) ${ }^{472}$

Com a garantia das liberdades individuais pelas revoluções burguesas, criam-se as condições necessárias para o surgimento de uma esfera pública autônoma, concorrente com o Estado, mantida como espaço de comunicação cujo ingresso é livre para todo e qualquer cidadão. O filósofo alemão entende que, com o advento do estado social, a esfera pública foi debilitada de forma considerável pela penetração do poder econômico, que a transforma

\footnotetext{
${ }^{470}$ HABERMAS, Jügen. La esfera de lo publico. In: DÍAZ, Francisco Galván (comp.). Touraine y Habermas, Ensayos de teoría social. UP/UAM Azcapotzalco: México, 1986, pg. 124.

${ }^{471}$ HABERMAS, Jürgen. Ibidem, pg. 126

472 THOMPSON, John B. La teoría de la esfera publica. In: Voces y culturas, 10, 1996, pg. 83.
} 
em um espaço para enfrentamento de forças só interessadas na prevalência de interesses eminentemente privados.

Em texto publicado na década de sessenta do século XX, Habermas analisa as mudanças estruturais na esfera pública ${ }^{473}$, reconhecendo que tal esfera tem passado por transformações negativas. Segundo Thompson, esse texto constitui, na verdade, uma extensa reflexão sobre a natureza da vida pública e suas mudanças ao longo da história política do Ocidente. Para o intérprete de Habermas, a desintegração da esfera pública se inicia com o advento do estado social, marcado pelo intervencionismo crescente do Estado na sociedade civil ${ }^{474}$.

As mudanças estruturais indicadas pelo autor alemão se devem a uma "infiltração" do poder econômico no espaço público, a qual influencia o resultado dos processos decisórios. Essa influência é, segundo Habermas, provocada pelo crescimento da propaganda nos meios de comunicação, pela fusão entre entretenimento e informação e pelo consumo de uma produção profissionalizada da cultura. Para Neves e Lubenow, essa influência negativa acaba por gerar um excessivo poder da mídia, utilizado para manipulação dos cidadãos, que, uma vez prejudicados em sua autonomia, não seriam capazes de decisões racionais ${ }^{475}$.

Thomson indica, ainda, que, para Habermas, as disfunções da esfera pública burguesa podem ser identificadas ainda no curso do estado liberal, uma vez que, apesar de estar baseada no princípio de acesso universal, a esfera pública burguesa esteve restringida àqueles indivíduos que tinham educação e meios financeiros para participar $\operatorname{dela}^{476}$.

Apesar da leitura pessimista sobre as transformações da esfera pública na sociedade do consumo e da comunicação de massa, Habermas acredita que o fortalecimento da democracia, simbolizado pelo aumento da participação e pela tomada de consciência pública da importância do consenso para a legitimação do direito, pode promover uma transformação no espaço público de discussão.

\footnotetext{
${ }^{473}$ HABERMAS, Jürgen. Mudança Estrutural da Esfera Pública. Rio de Janeiro: Tempo Brasileiro, 1984. ${ }^{474}$ THOMPSON, John B. Op. cit.

${ }^{475}$ NEVES, Raphael; LUBENOW, Jorge. Entre promessas e desenganos: lutas sociais, esfera pública e direito. In: NOBRE, Marcos; TERRA, Ricardo (orgs.). Direito e Democracia: Um guia para leitura de Habermas. São Paulo: Malheiros, 2008, pg. 250.

${ }^{476}$ THOMPSON, John. B. Op. cit.
} 
Esse fortalecimento é garantido pela existência de esferas públicas autônomas, mantidas na periferia, e que também contribuem para o processo de tomada de decisão. Neves e Lubenow esclarecem:

\begin{abstract}
A periferia caracteriza-se por possuir esferas públicas informais, altamente diferenciadas e, por isso, mais porosas às tematizações de problemas que podem chegar ao sistema político. Essa periferia conta com uma vasta rede de esferas públicas cuja prática deliberativa consiste apenas em formar a opinião dos participantes, sem se ater a tomadas de decisão. ${ }^{477}$
\end{abstract}

Ao fortalecer a garantia dos direitos fundamentais como a liberdade de expressão, de associação, de pensamento, o Estado acaba por viabilizar, através do medium do direito, a sobrevivência da "periferia" constituída por esferas públicas especializadas capazes de promover uma contínua atualização da esfera pública política propriamente dita. A participação de tais sujeitos no processo de formação da vontade e da opinião é imprescindível, assim, para a própria sobrevivência da esfera pública.

A esfera pública democrática colabora de forma determinante para a ação do estado, legitimando, através da ampliação do debate, o resultado do processo de deliberação conduzido no ambiente parlamentar. Ao compreender o seu conceito, é possível perceber que, para Habermas, a tarefa de fundamentação do direito pressupõe o fortalecimento de uma esfera pública que permita ampliar os canais de diálogo, nos quais a ação comunicativa possa ser conduzida à luz do princípio do discurso.

\title{
6.4. O Processo de Formação da Vontade e da Opinião Política
}

Para explicar a tensão entre facticidade e validade, entre a pretensão de legitimidade e o aspecto coercitivo-impositivo do direito na modernidade, Habermas vai reconstruir o processo de formação da vontade e da opinião pública. Isso porque, como esclarece o autor, não é possível pensar o direito fora da realidade estatal. A relação entre política e direito não é mais uma relação de subordinação deste àquele, mas uma relação de coordenação recíproca, que permite conciliar a mencionada tensão.

${ }^{477}$ NEVES, Raphael; LUBENOW, Jorge. Ibidem, pg. 254. 
Para tanto, estado e direito estão ligados de forma indissociável, já que, para Habermas, a "perpetuação" do sistema de direitos depende da instauração ou aproveitamento funcional de um poder do Estado ${ }^{478}$. Nesse sentido, afirma o autor que:

O Estado é necessário como poder de organização, de sanção e de execução, porque os direitos têm que ser implantados, porque a comunidade de direito necessita de uma jurisdição organizada e de uma força para estabilizar a identidade, e porque a formação da vontade política cria programas que têm que ser implementados ${ }^{479}$.

Segundo o filósofo alemão, uma das características fundamentais da Modernidade é a cooriginariedade entre o poder político e o direito, fazendo nascer a figura do "estado de direito". Nesse sentido, há uma interligação entre soberania popular e liberdades subjetivas, de modo a que o princípio "todo o poder político parte do povo" vai ser concretizado através dos procedimentos e pressupostos comunicativos de uma formação institucionalmente diferenciada da opinião e da vontade ${ }^{480}$. O poder político, a partir do qual o direito nasce, é, ele próprio, delimitado por normas de direito fundadas na vontade popular, na soberania.

O poder político assume, assim, com a modernidade, a forma do direito positivo, isto é, um poder legal, sendo, na verdade, o medium através do qual o estado se organiza e opera (na implementação dos programas nascidos da deliberação popular). Estabilizando as expectativas de comportamento, o direito positivo faz nascer a figura do princípio da segurança jurídica, permitindo aos destinatários do direito calcular as consequências do comportamento próprio e alheio ${ }^{481}$. O estado, ao mesmo tempo em que controla a observância e a efetividade do direito, se define e atua mediante o direito, numa relação de coordenação. Nesse ponto, surge a tensão indicada por Habermas, entre o poder de imposição (ou dominação) monopolizado pelo Estado com fundamento no direito e a pretensão de que a ordem jurídica seja legítima, justa. Para resolver tal impasse, Habermas lança mão do princípio democrático, como condição de legitimação.

O direito positivo, para ser legítimo, precisa encontrar sua fonte em um poder comunicativo. Habermas menciona expressamente que se o poder da administração do Estado, constituído conforme o direito, não estiver apoiado num poder comunicativo

\footnotetext{
${ }^{478}$ HABERMAS, Jürgen. Direito e Democracia: entre facticidade e validade, v. I, $2^{\mathrm{a}}$ edição, tradução de Flávio Siebeneichler. Rio de Janeiro: Tempo Brasileiro, 2012, pg. 169.

${ }^{479}$ HABERMAS, Jürgen. Ibidem, pg.

${ }^{480}$ HABERMAS, Jürgen. Ibidem, pg. 173.

${ }^{481}$ HABERMAS, Jürgen. Ibidem, pg. 183.
} 
normatizador, a fonte da justiça, da qual o direito extrai sua legitimidade, secará ${ }^{482}$. O direito legítimo precisa ser resultante, portanto, de uma vontade comum nascida do consenso. O autor busca entender, portanto, como a vontade comum pode nascer validamente, dentro de uma estrutura que garanta não só a legitimidade, mas a racionalidade do resultado.

Contrariando a visão de Weber e se associando à ideia de poder exposta por Arendt, Habermas compreende que o poder político não constitui uma pura relação de dominação, a capacidade de impor mediante o uso da força, mas depende de relações de reconhecimento recíproco organizadas comunicativamente. Por esse motivo,

Ele [o poder] surge em lugares onde há uma formação da opinião e da
vontade, a qual, junto com a liberdade comunicativa que permite a cada
um "fazer uso público de sua razão em todos os sentidos", faz valer a
produtividade de um "modo de pensar mais amplo". Este tem por
característica "que cada um atém o seu juízo ao juízo de outros possíveis,
e se coloca no lugar de cada um dos outros" ${ }^{833}$.

O poder político, portanto, depende do reconhecimento da autonomia de cada um e da igualdade entre todos como condição para seu exercício. A atitude perfomativa de "se colocar no lugar de", fundante da esfera pública democrática, pressupõe o reconhecimento recíproco da dignidade de todos os seus membros. O princípio da dignidade humana, em sua dimensão normativa, garante iguais condições de participação. De fato, para Habermas, a ideia da dignidade humana é a dobradiça conceitual que conecta a moral do respeito igual por cada um com o direito positivo e com a legislação democrática de tal modo que, na sua cooperação sob circunstâncias históricas favoráveis, pôde emergir uma ordem política fundada nos direitos humanos ${ }^{484}$.

De acordo com a leitura de Neves sobre a concepção de Habermas sobre o direito, a tensão entre facticidade e validade (ou a conexão entre instrumentalidade e indisponibilidade) não deve ser desconsiderada, pois é estruturante na proposta habermasiana para o estado de direito. A tensão tem, na verdade, um significado decisivo no relacionamento do direito positivo (moderno) com a moral e a política. Longe de

\footnotetext{
${ }^{482}$ HABERMAS, Jürgen. Ibidem, pg. 186.

${ }^{483}$ HABERMAS, Jürgen. Ibidem, pg. 187.

${ }^{484}$ HABERMAS, Jürgen. O conceito de dignidade humana e a utopia realista dos direitos humanos. In: Sobre a Constituição da Europa, tradução de Denilson Werle, Luiz Repa e Rúrion Melo. São Paulo: Editora Unesp, 2012, pg. 17.
} 
implicar uma destruição da ordem jurídica, a relação entre facticidade e validade é constitutiva do próprio direito e do estado modernos ${ }^{485}$.

A positivação do direito não implica, como esclarece Neves, uma superação da exigência moral de fundamentação, na medida em que as expectativas de comportamento transformadas em norma legal têm uma pretensão à validade universalista ${ }^{486}$. Essa validade é resgatada pela via do processo legislativo democrático, do qual se destaca um "caráter legitimador". Isso porque, conforme a proposta teórica habermasiana, a coerção jurídica só se justifica quando a sua autorização baseia-se na expectativa de legitimidade vinculada à deliberação do legislador ${ }^{487}$.

Neves aponta que, no pensamento habermasiano,

O direito vale não apenas porque é posto, mas sim enquanto é posto de acordo com um procedimento democrático, no qual se expressa intersubjetivamente a autonomia dos cidadãos. [...] Habermas vai argumentar que a validade não se restringe à consistência da decisão, alegando que ela pressupõe a fundamentação moral e ético-política ${ }^{488}$.

Tendo em vista a exigência de fundamentação do direito pelo procedimento democrático e a relação entre autonomia privada e pública (ou entre soberania e direitos humanos), Habermas busca entender o processo de formação racional da vontade pública, a fim de que se oriente a aplicação do princípio do discurso.

No âmbito da esfera pública, é possível perceber a existência de diversas formas discursivas que participam decisivamente na formação da vontade, tais como o discurso moral, ético-político, pragmático e mesmo jurídico ${ }^{489}$. Tal processo implica uma conexão complexa entre os diversos níveis de discurso, de modo a que se garanta a aceitabilidade racional dos resultados oriundos do procedimento ${ }^{490}$.

Habermas entende que o estado de direito pode sintetizar a ideia de transformar o poder comunicativo - racionalmente comprometido - em poder administrativo, de modo que o direito atue como medium através do qual essa transformação se faz possível. Desse

\footnotetext{
${ }^{485}$ NEVES, Marcelo. Entre Têmis e Leviatã: Uma relação difícil. São Paulo: Martins Fontes, 2008 , pg. 110.

${ }^{486}$ NEVES, Marcelo. Ibidem, pg. 111.

${ }^{487}$ NEVES, Marcelo. Ibidem, pg. 112.

${ }^{488}$ NEVES, Marcelo. Ibidem, pg. 114.

${ }^{489}$ Para uma explicação de cada uma dessas manifestações discursivas, remete-se a: HABERMAS, Jürgen. Direito e Democracia: entre facticidade e validade, v. I, $2^{\mathrm{a}}$ edição, tradução de Flávio Siebeneichler. Rio de Janeiro: Tempo Brasileiro, 2012, pg. 200 e ss; NEVES, Marcelo. Entre Têmis e Leviatã: Uma relação difícil. São Paulo: Martins Fontes, 2008, pg. 120.

${ }^{490}$ NEVES, Marcelo. Ibidem, pg. 120.
} 
modo, mesmo a concorrência pelo acesso ao sistema político ou o jogo de interesses motivado pelo agir estratégico podem ser conduzidos pela normatividade fundamentada racionalmente, internalizando-se e conduzindo-se tais tensões sem que o mundo da vida acabe sendo colonizado pelo domínio do dinheiro, da técnica ou do poder. Por isso, $o$ poder administrativo não deve reproduzir-se a si mesmo e sim regenerar-se a partir da transformação do poder comunicativo ${ }^{491}$.

Indicando o caminho de formação legítima do direito pela ação do poder comunicativo, Habermas indica a fundamentalidade do princípio do discurso para o êxito de tal objetivo. O princípio do discurso teria, assim, dois sentidos, um sentido cognitivo, responsável por filtrar temas, contribuições, argumentos e informações, e um sentido prático, voltado à produção de relações de entendimento sobre as leis e políticas a serem tomadas no âmbito do estado. De acordo com esse mecanismo, a normatização discursiva do direito se dá a partir da formação comunicativa do poder, por intermédio do procedimento estruturado a partir do princípio do discurso ${ }^{492}$.

O direito produzido de acordo com essa estrutura de organização do poder, embora se relacione com a moral por exigência de fundamentação racional, dela se distingue por sua concretude histórica, motivada tanto pelo modo de legislação, com pelo sentido de sua validade e pelo seu conteúdo normativo ${ }^{493}$.

Pelo princípio do discurso tem-se que qualquer norma de ação retira sua validade do assentimento daqueles que, na qualidade de atingidos, tomam parte em "discursos racionais". Conforme esclarece Habermas,

\footnotetext{
No caso de conflitos de ação, quando se impõem determinados problemas que precisam ser enfrentados cooperativos ou solucionados consensualmente, uma coletividade é confrontada com a pergunta: "o que devemos fazer?" O tratamento racional dessas questões exige uma formação da opinião e da vontade que leva a resoluções fundamentadas sobre a persecução de fins coletivos e sobre a regulamentação normativa da convivência ${ }^{494}$.
}

O assentimento comum se dá, então, a partir de uma organização cooperativa de sujeitos comprometidos com a regulação legítima de suas expectativas de ação, através da positivação das normas jurídicas. A coletividade que delibera se transforma, assim, numa

\footnotetext{
${ }^{491}$ HABERMAS, Jürgen. Direito e Democracia: entre facticidade e validade, v. I, $2^{\text {a }}$ edição, tradução de Flávio Siebeneichler. Rio de Janeiro: Tempo Brasileiro, 2012, pg. 190.

${ }^{492}$ HABERMAS, Jürgen. Ibidem, pg. 191.

${ }^{493}$ HABERMAS, Jürgen. Ibidem, pg. 192.

${ }^{494}$ HABERMAS, Jürgen. Ibidem, pg. 199.
} 
coletividade de parceiros, que exercitam sua autonomia no interior de um sistema de $\operatorname{direitos}^{495}$. A compreensão do processo de formação da vontade e opinião política depende, ainda, da relação que se manifesta entre as formas de discurso das questões pragmáticas, morais e ético-políticas.

As questões pragmáticas são aquelas que mais se aproximam do agir estratégico, na medida em que se colocam na perspectiva de um ator que procura os meios apropriados para a realização de preferências e fins que já são dados ${ }^{496}$. Tais questões dependem de solução a partir da ação do poder comunicativo, uma vez que a ponderação de fins, orientada por valores, e a ponderação pragmática de meios, leva a recomendações hipotéticas que colocam em relação as causas e efeitos, de acordo com preferências axiológicas e finalidades ${ }^{497}$.

Muitas vezes, como esclarece o autor, as questões pragmáticas acabam por depender da superação de questões ético-políticas, pois a decisão sobre os meios e os fins está de tal modo associada às formas de vida compartilhadas que se faz necessária uma indagação sobre a forma de vida em si mesma. Tais questionamentos ético-políticos são simbolizados pelas indagações existenciais referentes a: “quem sou eu?”, “quem desejo ser?", “que tipo de vida é bom pra mim?”, tomadas não no singular, como manifestação de uma individualidade que pensa, mas em seu sentido coletivo. Em outras palavras, questionamentos pragmáticos, sobre a decisão dos melhores meios para alcançar determinados fins, quase sempre dependem de esclarecimentos de natureza ético-política sobre a própria forma de vida considerada boa pela coletividade de sujeitos participantes do discurso. Antes de saber como planejar e executar as políticas de educação, por exemplo, é preciso refletir sobre o sentido mesmo de projeto educacional que a sociedade deseja alcançar com as políticas públicas.

O filósofo alemão sintetiza, assim, a relação entre o discurso pragmático e o discurso ético-político:

Em discursos pragmáticos, nós examinamos se as estratégias de ação são adequadas a um fim, pressupondo que nós sabemos o que queremos. Em discursos ético-políticos, nós nos certificamos de uma configuração de valores sob o pressuposto de que nós ainda não sabemos o que queremos realmente. Em discursos desse tipo, é possível fundamentar programas, na

\footnotetext{
${ }^{495}$ HABERMAS, Jürgen. $O p$. cit.

${ }^{496}$ HABERMAS, Jürgen. Ibidem, pg. 200.

${ }^{497}$ HABERMAS, Jürgen. Op. cit.
} 

medida em que eles são adequados e, num sentido amplo, bons para
nós.

O discurso pragmático e o ético-político não são suficientes, na medida em que também é necessário levar em consideração a justiça do resultado pretendido. Nesse sentido, conforme a análise habermasiana, uma norma só é justa, quando todos podem querer que ela seja seguida por qualquer pessoa em situações semelhantes ${ }^{499}$. Entra, neste ponto do processo de formação da vontade política, o discurso moral, estreitamente relacionado à definição de imperativos de ação universais, fundados pela razão (princípio da universalização).

Esse aspecto universalista do discurso moral é manifesto por Habermas, ao afirmar que em tal nível discursivo são decisivos os argumentos que conseguem mostrar que os interesses incorporados em normas contestadas são pura e simplesmente generalizáveis. Isso porque a concretude espacial e temporal do direito cede lugar a uma perspectiva mais abrangente, referente a uma comunidade comunicativa não-circunscrita, onde cada membro se coloca na situação, na compreensão e na autocompreensão do mundo de cada um dos outros ${ }^{500}$. Isso quer dizer que, no discurso moral, se o sujeito pretende validade para determinada norma de ação, essa validade necessariamente será universal, não podendo ser delimitada espacial e culturalmente.

É por esse motivo que, para Habermas, direito e moral não se confundem, tanto em virtude da existência de um nível de discurso pragmático e ético-político, como pela necessidade de um recurso ao argumento moral como meio de fundamentação da ordem legislada. A relação não é de coincidência entre os âmbitos de normatividade, mas de coordenação recíproca: o direito precisa da moral como forma de fundamentação da ordem de dominação imposta, legitimando-a, sem, contudo, reduzir a ordem jurídica a um código moral abstrato.

A formação da vontade e da opinião pública no estado democrático de direito é, portanto, resultante de embates discursivos entre sujeitos autônomos e comprometidos com a legitimação, nos quais serão empregados diferentes níveis discursivos, empregando-se o recurso a questões morais, ético-políticas e pragmáticas. Através desse processo complexo em que o objetivo final é o assentimento de todos os possíveis envolvidos, a decisão é

\footnotetext{
${ }^{498}$ HABERMAS, Jürgen. Ibidem, pg. 202.

${ }^{499}$ HABERMAS, Jürgen. Ibidem, pg. 203.

${ }^{500}$ HABERMAS, Jürgen. Op. cit.
} 
instrumentalizada em direito legislado, permitindo ao estado transformar o poder comunicativo em poder administrativo, a fim de executar as políticas e programas almejados.

Os princípios do estado de direito tem a função de estabelecer, assim, como é possível a institucionalização jurídica da rede de discursos e negociações necessárias à formação da vontade e da opinião na esfera pública. Para o filósofo alemão:

Na linha da teoria do discurso, o princípio da soberania do povo significa
que todo o poder político é deduzido do poder comunicativo dos
cidadãos. O exercício do poder político orienta-se e se legitima pelas leis
que os cidadãos criam para si mesmos numa formação de opinião e da
vontade estruturada discursivamente. Quando se considera essa prática
como um processo destinado a resolver problemas, descobre-se que ela
deve a sua forma legitimadora a um processo democrático destinado a
garantir um tratamento racional de questões políticas. ${ }^{501}$

A citação é esclarecedora, pois indica que somente através do processo democrático é possível "garantir um tratamento racional" para os assuntos de estado e, por consequência, pretender legitimidade para a ordem jurídica. Ao institucionalizar o processo de formação da vontade, é possível garantir o emprego efetivo de liberdades comunicativas iguais e simultaneamente estimula para o uso pragmático, ético e moral da razão prática $^{502}$. O resultado necessário é a recuperação dos vínculos de solidariedade e o aumento do espaço de autonomia individual mediante o uso público da razão.

É preciso compreender que, para Habermas, a esfera pública não se esgota no âmbito formal do estado, pois o filósofo prega a necessidade de preservar o princípio do pluralismo político e a necessidade de garantir espaços informais de formação da vontade e da opinião, abertos a todos os cidadãos. Essas "arenas informais" permitem o fluxo livre de opiniões, pretensões de validade e tomadas de posição ${ }^{503}$, ampliando consideravelmente a efetividade do direito à participação política pela inclusão no debate.

Segundo o autor, haveria uma verdadeira destruição da base do funcionamento racional do processo de formação da vontade e da opinião pública na hipótese de exclusão dass fontes espontâneas das esferas públicas autônomas, impedindo o fluxo de temas,

\footnotetext{
${ }^{501}$ HABERMAS, Jürgen. Ibidem, pg. 213.

${ }^{502}$ HABERMAS, Jürgen. Op. cit.

${ }^{503}$ HABERMAS, Jürgen. Ibidem, pg. 214.
} 
contribuições e argumentos, que flutuam livremente numa esfera pré-política estruturada igualitariamente $^{504}$.

Mas o que se deve entender por "institucionalização" do processo de formação da vontade e da opinião pública? De acordo com Habermas, a institucionalização ocorre sempre que as expectativas de comportamento ganham status normativo, de tal modo que os membros de uma coletividade social sabem qual comportamento eles podem estimular, em que circunstâncias e quando ${ }^{505}$. Rigorosamente, a institucionalização precisa ocorrer quanto aos procedimentos que permitem a formação da vontade, a partir da seleção e da organização dos diferentes níveis de discurso.

Por isso, afirma Habermas:

Normas de procedimento regulam, por exemplo, a participação em processos de formação da opinião e da vontade, dirigidos argumentativamente, bem como a distribuição de papéis nesse processo, o leque temático e o seu próprio fluxo. Desta maneira, os meios do direito são introduzidos reflexivamente, a fim de que discursos que normatizam o direito e os que o aplicam possam ser esperados socialmente em determinados lugares e em épocas determinadas ${ }^{506}$.

A ação do poder comunicativo na esfera pública depende, pois, de uma organização mínima da participação dos potenciais sujeitos, a fim de que o assentimento racional possa ser dado por todos e a melhor solução encontrada. Os procedimentos que estruturam a participação - nos diversos tipos de processo de deliberação pública - são indispensáveis à formação legítima da vontade e da opinião a partir do princípio do discurso. A teoria do discurso interpretada à luz da colaboração habermasiana leva a proposta democrática às últimas consequências, ao só reconhecer legitimidade a normas originadas do consenso.

O conceito de democracia radical de Habermas não escapa, todavia, a uma análise crítica operada pelo próprio filósofo, ao reconhecer que a sociologia da comunicação de massas é cética quanto às possibilidades oferecidas pelas esferas públicas tradicionais das democracias ocidentais, dominadas pelo poder e pela mídia ${ }^{507}$. A sociedade civil organizada, apesar de se mostrar sensível aos problemas políticos enfrentados pelo grupo, não tem força suficiente para orientar os processos de decisão ou mesmo para "despertar o processo de aprendizagem no sistema político", como menciona o autor.

\footnotetext{
${ }^{504}$ HABERMAS, Jürgen. Ibidem, pg. 229.

${ }^{505}$ HABERMAS, Jürgen. Ibidem, pg. 221.

${ }^{506}$ HABERMAS, Jürgen. Ibidem, pg. 222.

${ }^{507}$ HABERMAS, Jürgen. Direito e Democracia: entre facticidade e validade, v. II, $1^{\mathrm{a}}$ edição, tradução de Flávio Siebeneichler. Rio de Janeiro: Tempo Brasileiro, 2011, pg. 107.
} 
Apesar dessa percepção, Habermas entende que a esfera pública geral, definida formalmente pelo sistema político, tem fronteiras fluidas, que permitem a criação de canais de diálogo com a esfera pública episódica e a esfera pública abstrata, caracterizadas pela informalidade e pela sua constituição em linguagem comum. Tem-se, com esse diálogo, a criação de "pontes hermenêuticas" que permitem o mútuo aprendizado, sendo justamente esse o canal de participação das arenas informais nos processos de formação da vontade e da opinião pública ${ }^{508}$.

Seja com a participação direta do representante político na assembleia nacional, seja com a publicação de uma opinião na mídia impressa, tem-se formas de participação no processo discursivo cujo objetivo é a decisão sobre a melhor norma. Nesse ponto, a esfera pública é entendida em suas múltiplas manifestações, de modo a abarcar e a filtrar os argumentos, as teses, as opiniões que são manifestas pelos sujeitos participantes do discurso. A partir dessa perspectiva, tão mais inclusivo será o sistema político quanto maiores forem as chances de "filtrar", pelo procedimento de formação da vontade pública, o melhor argumento possível.

É possível concluir que o modelo habermasiano de fundamentação do direito está ancorado na razão comunicativa e na aplicação do princípio do discurso em organizações democráticas. Sua proposta só entende como legítima as ordens jurídicas produzidas pelos próprios destinatários, quando todos os potenciais envolvidos sejam capazes de conferir seu assentimento racional. Em sua análise, ao levar em considerações elementos empíricos, Habermas reconhece que, em determinados momentos, negociações são tomadas a fim de garantir a observância de interesses privados, mas que, uma vez conduzidas dentro de um processo global e organizado de formação da vontade, mesmo tais negociações podem ocorrer sem prejuízo à democracia e à prevalência da melhor razão pública.

A contribuição teórica habermasiana pode ser especialmente útil para analisar a validade de normas infraconstitucionais à luz dos postulados constitucionais. Isso porque o princípio democrático e o princípio do discurso encontram-se internalizados na ordem jurídica através da previsão dos procedimentos de formação da vontade e da opinião na própria constituição, como aqueles referentes ao processo legislativo. Assim, quando determinada norma, embora produzida a partir de um procedimento formalmente perfeito,

${ }^{508}$ HABERMAS Jürgen. Ibidem, pg. 108. 
tenha vícios referentes à análise racional dos argumentos em debate pelos representantes parlamentares, poderá ser considerada inválida por vício de constitucionalidade.

A experiência recente brasileira oferece um exemplo típico de inconstitucionalidade originária de normas infraconstitucionais motivada pelo vício no processo de formação da vontade e da opinião. O caso conhecido publicamente como "mensalão" demonstra que determinados parlamentares condicionaram a aprovação de projetos de lei ao recebimento de dinheiro. Nessa hipótese, verifica-se que o consenso parlamentar construído em torno de determinada norma de ação não foi fruto de uma análise exaustiva dos argumentos expostos na esfera pública estatal, ou mesmo oriundo do debate difuso das esferas públicas periféricas, mas motivado por um ganho econômico privado. Ainda que o tribunal constitucional tenha reconhecido a validade formal de tais normas, constata-se um vício originário em sua formação - o vício da formação da vontade.

No que tange ao processo constituinte, é possível utilizar o esquema habermasiano, no qual o autor relaciona o princípio do discurso aos processos de deliberação pública no ambiente democrático, para prever e indicar as estruturas, as normas, as instituições e os direitos primários que qualquer constituição precisa prever para garantir a estabilidade e a permanência da ordem jurídica legítima.

\subsection{A Contribuição Teórica Habermasiana e a Teoria da Constituição}

A análise habermasiana sobre a relação entre direitos humanos, teoria da democracia e a ética do discurso permite uma releitura da teoria constitucional, a fim de que se defina um novo papel para a constituição no sistema político. A função da constituição seria, então, a estruturação dos procedimentos que garantem o exercício do direito de participação político e que viabilizam o processo de formação da vontade pública a partir de parâmetros legítimos.

Habermas não analisou especificamente a relevância do poder constituinte para a institucionalização dos procedimentos que, segundo ele, permitem a aplicação do princípio do discurso dentro da esfera pública democrática. Neste ponto, entende-se que, apesar de não haver essa análise clara em sua teoria, é possível fazer uso de sua contribuição para 
pensar sobre a teoria do poder constituinte e sobre os limites e as possibilidades da teoria constitucional hoje.

A teoria clássica do poder constituinte, exposta nos capítulos I e II do trabalho, é fundada na concepção de poder forjada pelo liberalismo político das revoluções burguesas: a potência criadora do direito e do estado - simbolizada pelo poder constituinte - está nas mãos do povo, que, soberano, não encontra limitações ou condicionamentos no exercício de sua capacidade de legislar. Embora esteja, na visão clássica, pressuposta a noção de autonomia moral própria de qualquer autolegislação, não é possível perceber, da leitura dos teóricos clássicos, qualquer menção clara a limites objetivos à atividade soberana do povo em sua tarefa de construir o estado, definindo o espaço do político.

Habermas, em contrapartida, pensa que o direito positivo, ao pretender validade, precisa ser legitimado por intermédio de um procedimento democrático através dos quais todos os potenciais atingidos podem consentir com a normatização, manifestando seu assentimento. Pensando que, com essa estrutura, o sujeito é, ao mesmo tempo, o destinatário e o produtor da norma, Habermas sustenta seu argumento na ideia de cooriginariedade entre autonomia privada e autonomia pública, que torna infrutífero o antagonismo entre soberania popular e direitos humanos. Um povo que, soberano, pretenda exercer sua liberdade não pode fazê-lo ao abrir mão de direitos fundamentais, de modo que tais direitos são pressupostos em qualquer organização que busque a positivação legítima de normas de ação.

Para o autor, então, tais direitos constituem não só pressupostos, mas verdadeiros pilares da organização democrática autônoma: são exigências racionais de legitimação que precisam ser contempladas pela ordem jurídica para que esta tenha sua validade racional assegurada. O filósofo alemão vai, ainda, explicar como, com base em tais direitos básicos, é possível formar a vontade pública, a partir do poder comunicativo.

O direito, na modernidade, assume, para Habermas, a função de conduzir a tensão existente entre a expectativa de fundamentação moral e a positividade. Não é sustentável, porque fatalmente caminhará para destruição, uma ordem positiva que não se fundamente em argumentos reconhecidos intersubjetivamente pelos potenciais destinatários das normas de ação. 
A constituição ganha um relevo especial nesse panorama argumentativo. Se o sistema jurídico é, do ponto de vista operativo, fechado - a ponto de se falar, na teoria do direito, no "dogma" da completude do ordenamento - é a constituição é o fundamento último de validade de todas as subnormas, de modo que, de forma direta, a validade da própria constituição afeta, em cadeia, a validade das demais normas jurídicas a ela subordinadas. O discurso de fundamentação do direito é, assim, em primeiro lugar, um discurso de fundamentação da carta constitucional.

Qualquer proposta de fundamentação da constituição deve partir da análise da dinâmica do poder constituinte, especialmente se a perspectiva adotada para compreensão do estado de direito for aquela exposta por Habermas, que reconhece como indispensável um resgate moral do direito pela via do discurso democrático. Isso porque é através do poder constituinte que a comunidade de sujeitos livres pode deliberar, originariamente, sobre os direitos básicos de seu sistema jurídico, bem como institucionalizar os procedimentos que permitirão a perpetuação do debate plural e inclusivo na esfera pública.

Ao definir os canais de participação - e mesmo a extensão dos direitos políticos - a constituição pode alargar ou reduzir a esfera pública, no que tange à sua capacidade de interferir no resultado do processo de elaboração normativa. Uma esfera pública pluralista e inclusiva dará origem a um direito legitimado pela participação democrática, que terá maiores níveis de efetividade porque amparado em vínculos de solidariedade. Tomando a constituição como uma norma escrita, estruturada, que forma, ela própria, um sistema coerente de princípios e garantias, tem-se que sua função primordial é delimitar as funções do Estado, definindo quais são as instituições do estado, suas competências, seus canais de acesso e procedimento através do qual essa instituição irá operar.

O resultado do trabalho do poder constituinte interfere de forma decisiva no sucesso da tarefa de legitimação da ordem jurídica e de institucionalização dos procedimentos democráticos de formação da vontade pública. Compreendendo-se que existe uma determinada forma de estabelecer os papeis do estado e, também, direitos que existem in statu nascendi, é possível constatar que os postulados da ilimitação material e do incondicionamento do poder constituinte em sua feição clássica não são sustentáveis racionalmente, pois poderiam conduzir à negação das bases que garantem à ordem democrática sua sobrevivência. 
No capítulo seguinte expõem-se, assim, os principais postulados de uma teoria democrática do poder constituinte, construída à luz da concepção de estado de direito habermasiana. 


\section{A TEORIA DO PODER CONSTITUINTE DEMOCRÁTICO}

A teoria constitucional contemporânea precisa cuidar de uma preocupação fundamental que permeia todos os sistemas jurídicos do mundo ocidental: explicar e definir a dinâmica do discurso de fundamentação normativa e do resgate da legitimidade política das ordens estatais. Como pode o direito positivado ser, além da manifestação de força e de dominação de um estado que se põe soberanamente, a expressão de uma ordem justa, legítima, exigível não só coertivamente, mas racionalmente?

A constituição, apresentada como a fonte axiológica e procedimental do sistema jurídico, também carece, ela mesma, de um fundamento valorativo que lhe permita sustentar-se em tempos de crise, evitando um esvaziamento normativo durante os processos de revisão constitucional - problema especialmente sensível em democracias recentes, que convivem com uma instabilidade política que se reflete na fluidez e mutabilidade casuística das normas jurídicas.

A teoria habermasiana constitui uma proposta de interpretação do direito que condiciona sua validade ao resgate do discurso moral e da institucionalização do direito mediante um procedimento democrático. Há, como evidencia o filósofo alemão, uma evidente relação entre o político e o jurídico, além de uma cooriginariedade entre direito e moral que foi negligenciada pela teoria positivista do direito no século XX e que precisa ser resgatada antes que o direito seja inteiramente subordinado ao poder econômico e ao domínio da técnica.

A preocupação com o resgate moral do direito não constitui um mero dilentatismo teórico, uma vez que os processos de aplicação do direito - e em especial das normas referentes aos direitos humanos - cada vez mais têm suscitado o debate popular. Essa movimentação pode ser entendida como resultado de uma autocompreensão da relevância de tais questões para a própria sobrevivência de um modo de vida compartilhado pelo Ocidente, organizado a partir da lógica do liberalismo político, do postulado da autonomia individual e do princípio da dignidade humana. 
A análise da fundamentação da ordem jurídica acaba por desencadear uma reflexão generalizada sobre as bases teóricas em que se assenta o direito positivo nascido das revoluções burguesas, ainda no século XVIII, e levado às últimas consequências por Kelsen e sua teoria pura do direito. Um dos resultados de um compromisso teórico com a fundamentação racional do direito é a promoção de releituras dos dogmas tradicionais, da já desgastada compreensão positivista do ordenamento jurídico e seu modo de operação: o postulado do fechamento sistêmico que afastou, durante décadas, o questionamento ético sobre a validade do direito.

A falta de legitimidade de normas jurídicas positivadas (e formalmente válidas conforme uma compreensão tradicional de direito positivo) consideradas nocivas à preservação da liberdade e da dignidade humana provocam um desconforto não apenas teórico, mas um déficit de legitimidade que conduz ao prejuízo da efetividade das normas jurídicas.

Neste trabalho, o problema da fundamentação normativa é enfrentado a partir da análise da dinâmica do processo constituinte, tendo em vista a produção originária das normas que constituem o parâmetro último de validade de todo o sistema jurídico.

Entendida como modalidade extraordinária de nomogênese, o processo constituinte é um momento temporal e espacialmente delimitado, a partir do qual uma sociedade politicamente organizada decide refundar a ordem jurídica em novos pilares axiológicos. A elaboração da nova constituição é um processo que se inicia com a percepção da insuficiência da ordem constitucional anterior até o momento de conclusão dos trabalhos de produção normativa, simbolizado pela promulgação de seu texto.

Em culturas jurídicas desenvolvidas a partir da matriz do civil law, a ordem jurídica se manifesta em sua expressão formal, escrita, geral e abstrata. A constituição, aqui, também se reveste de tais características, assumindo a figura de um sistema normativo especial, tanto hierárquica, como material e formalmente: trata-se do conjunto de dispositivos normativos mais importante do Direito, entendido como totalidade coerente e organizada, e, uma vez substituída a constituição, altera-se por completo o fundamento de validade da normatividade infraconstitucional, ainda que lhe seja anterior.

O processo constituinte, entendido como amplo movimento social de mudança normativa, está, todo ele, impregnado de referências culturais: uma sociedade situada no 
tempo e no espaço, ao reavaliar sua ordem jurídica, o faz a partir de instituições, direitos, garantias e procedimentos já existentes e que, tanto direta como indiretamente, interferem no resultado do processo constituinte.

Dita percepção, embora intuitiva, precisa ser ressaltada, na medida em que, de acordo com a proposta teórica clássica exposta no começo do percurso argumentativo deste trabalho, o poder constituinte é entedido como potência que provoca uma subversão com o sistema anterior, uma mudança completa, originária, revolucionária, portanto. Esse postulado, que se sustentou num contexto de crise completa, representativa do próprio nascimento de uma nova forma de interação entre direito e política no advento da Modernidade, não é próprio para entender o processo constituinte no Ocidente hoje, quando se tem estados nacionais já consolidados como democracias independentes, participantes de uma comunidade internacional de estados comprometida com o respeito a um rol de direitos humanos específicos, aí incluídos os direitos políticos de participação.

Isso implica que o exercício do poder constituinte, quando exercido em estados já organizados democraticamente, não implicará uma completa subversão da ordem jurídica anterior, sendo mesmo problemático sustentar determinados dogmas já assentados na teoria constitucional, tais como aquele que declara a inexistência de direito adquirido em face da nova constituição.

Como explicar a um povo soberano que, com a promulgação da nova ordem constitucional, garantias e direitos já em condições de serem exercidos conforme a ordem anterior simplesmente deixam de ter sua validade reconhecida perante o Estado? Essa conclusão não se sustenta quando se pretende que o direito, além de um fundamento formal, também seja resultante de um discurso de fundamentação amparado eticamente numa razão comunicativa universal. O direito infraconstitucional, quando fundamentado racionalmente, tem uma pretensão de validade que não pode ser olvidada pela constituição, na medida em que o direito adquirido validamente, por ser um direito exigível e legítimo, se põe em face do outro e, também, em face do Estado, já que ele é a manifestação da validade de uma ordem, ainda que anterior, mas uma ordem válida no lapso temporal de sua vigência.

Ora, ampliando-se o âmbito de análise do argumento sobre o direito adquirido, indaga-se: como aceitar a possibilidade de uma mudança degenerativa dos direitos e liberdades já adquiridos pela sociedade política? Tem-se, nesse ponto, a manifestação da 
exigibilidade universal do princípio da proibição do retrocesso. Isso porque direitos, instituições e procedimentos também podem constituir aquisições culturais imunes à atuação do processo constituinte, sempre que essa intangibilidade representar uma proteção contra o retrocesso normativo, entendendo-se por retrocesso toda mudança que implique na diminuição no âmbito de proteção de um espaço de autonomia privada ou pública já conquistado normativamente.

Desse modo, é questionável a validade moral e - por conseguinte - jurídica de normas constitucionais, ainda que provenientes do constituinte originário, quando impliquem na redução das liberdades conquistadas pela comunidade de sujeitos ao longo de seu desenvolvimento. Essa conclusão não representa uma incongruência frente ao princípio da soberania popular, se se levar em consideração que os atos constituintes são obra de representantes parlamentares eleitos, que não dispõem, na qualidade de representantes, de total liberdade de decisão. A decisão do representante deve ser, em ordens democráticas, um eco da disposição dos mandatários, de modo que qualquer decisão que contrarie ou diminua o espaço de decisão daquele que está investido da soberania é inválida em virtude de seu déficit de legitimidade.

Em face de tais argumentos, entende-se o processo constituinte como um movimento de continuidade, ainda que a nova constituição represente uma mudança no fundamento de validade formal do sistema normativo. A continuidade aqui deve ser compreendida tanto no sentido temporal-cultural, isto é, o processo constituinte não implica a perda do passado da comunidade política em sua conquista pela autonomia, como no sentido normativo, já que a legislação infraconstitucional permanece parcialmente vigente, sendo recebida, por um ato de ficção jurídica, pela nova ordem constitucional, com a consequente mudança do fundamento hierárquico de validade.

Uma das principais dificuldades da releitura de postulados tão caros à teoria constitucional construída desde o século XIX é a possível violação ao princípio da segurança jurídica, ou mesmo a perda da força normativa da constituição, entendida em sua realidade positiva. Tais questionamentos precisam ser enfrentados oportunamente para que, ao final, os delineamentos da nova proposta teórica para o poder constituinte não representem, eles próprios, um risco à democracia.

Considerando-se, pois, o processo constituinte como continuidade e o princípio da proibição do retrocesso, é possível apresentar os principais postulados de uma teoria do 
poder constituinte revista em seus dogmas clássicos a partir dos pressupostos filosóficos expostos nos capítulos anteriores.

\subsection{A proposta teórica: delineamentos gerais}

O poder constituinte pode ser entendido como uma das diversas expressões do poder comunicativo no âmbito da sociedade política. Trata-se da força criadora capaz de transformar consensos sobre normas de ação, alcançados intersubjetivamente conforme um procedimento democrático, em normas constitucionais. Desse modo, entende-se por poder constituinte a manifestação do poder popular voltada à produção de uma nova carta constitucional, sendo o processo de elaboração conduzido por intermédio do princípio do discurso.

É pela ação do poder constituinte que se tem a refundação das bases normativas em que se assenta o estado, simbolizada pela transformação da ordem constitucional positivada. Trata-se, portanto, de uma iniciativa de mudança, que pode ganhar contornos e magnitude diversos conforme as circunstâncias históricas específicas. Isso porque o poder constituinte tanto pode representar - no caso das democracias recentes - uma mudança de grandes proporções nas competências institucionais e na garantia do espaço de liberdade individual, como pode simbolizar uma mudança que não desestrutura, por completo, a identidade estatal, tanto no que tange às instituições, como na lógica interna do sistema normativo.

Rigorosamente, o poder constituinte hoje, salvo casos excepcionais, não representa a criação de estados inteiramente novos, cujo processo de "construção" se dá a partir da definição dos elementos primários referentes à identificação de um povo e à delimitação de território. Com algumas exceções, em geral oriundas dos territórios dominados pelo colonialismo tardio nos continentes africano e asiático, o poder constituinte tem se apresentado como processo de reforma das bases institucionais já delimitadas desde o advento da Modernidade, a partir de uma reorganização das instituições, das competências, dos procedimentos e, principalmente, do rol dos direitos fundamentais assegurados. 
No Brasil, é possível identificar mudanças consideráveis na identidade constitucional entre as duas últimas constituições, de 1967 e 1988. Enquanto a carta de 1967 foi responsável pela organização de um estado não democrático, no qual uma hipertrofia do poder executivo representou uma diminuição sensível do espaço de autonomia individual e da garantia dos direitos fundamentais; em 1988, tem-se o advento de uma ordem jurídica marcada pelo desejo social de redemocratização, o que explica o caráter garantista e dirigente da última carta. Apesar da mudança de grandes proporções na orientação axiológica entre as constituições, o arcabouço institucional é fundamentalmente o mesmo. O que muda, pode-se concluir, é o projeto político, o equilíbrio das relações de poder e, também, a compreensão dos limites da relação existente entre sociedade e estado.

Tavares vai ao encontro dessa análise, ao entender que a constituição de 1988 é fruto de uma evolução jurídica, mas situada dentro de uma continuidade histórica. Como esclarece o constitucionalista, a nova constituição [de 1988] não ensejará um novo Estado. O Brasil já existe, com esta ou com outras eventuais e futuras constituições. Então, pelo menos por isso, a Constituinte tem limitações ${ }^{509}$.

Enquanto que a observação da prática do poder constituinte doméstico não oferece grandes surpresas em termos de inovação, é possível identificar uma manifestação inteiramente nova, referente à formação dos blocos transnacionais, cujo exemplo maior é a União Europeia. Segundo Habermas, a fragmentação política observada na Europa vai na contramão da construção de uma sociedade mundial e multicultural. Com a organização do bloco transnacional, uma iniciativa de unificação foi concluída, quando se observou uma "duplicação" do poder constituinte, que passa a ser compartilhado entre os cidadãos e os estados componentes da "federação desestatizada". Trata-se de um "poder constituinte misto" representado pela inclusão de um novo sujeito constituinte (os estados), quando até então se identificava a titularidade exclusiva pertencente aos cidadãos ${ }^{510}$.

Ainda confuso em seu exercício e em seus limites, o poder constituinte misto motor da criação do bloco europeu é identificado, por muitos, como um fracasso em termos de

\footnotetext{
${ }^{509}$ TAVARES, André R. Reflexões sobre a legitimidade e as limitações do poder constituinte, da assembleia constituinte e da competência constitucional reformadora. In: Cadernos de Direito Constitucional e Ciência Política, n. 21, ano 5, out.-dez./1997, Revista dos Tribunais, São Paulo, pg. 231.

${ }^{510}$ HABERMAS, Jürgen. A crise da União Europeia à luz de uma constitucionalização do direito das gentes: Um ensaio sobre a constituição da Europa. In: HABERMAS, Jürgen. Sobre a Constituição da Europa, tradução de Denilson Werle e Luiz Melo. São Paulo: Editora Unesp, 2012, pg. 72.
} 
criação de uma sociedade política comum para a Europa, o que revela as dificuldades de criação de um projeto multicultural compartilhado.

Em face de tais indagações, percebe-se que o estudo sobre o exercício do poder constituinte "toca em questões de legitimação democrática", na medida em que, com a elaboração da constituição, tem-se a fundação original da ordem jurídica a partir de um núcleo de decisões fundamentais sobre a forma de vida compartilhada pela sociedade. A relevância de seu estudo, mesmo em tempos de aparente estabilidade política no Brasil, é notória.

A teoria do poder constituinte democrático proposta nesta tese, que constitui uma releitura da teoria clássica construída à luz do liberalismo burguês, se define, então, como: a) uma teoria do direito positivo; b) uma teoria do exercício do poder popular na democracia; c) uma teoria do poder constituinte como poder comunicativo, orientado pela razão dialogal.

Como teoria do direito positivo, tem-se que não se pretende um resgate, com a proposta apresentada, do direito natural. O fundamento de validade da norma constitucional, embora não esteja positivado, se faz através do processo de institucionalização normativa, por meio de uma deliberação inclusiva e generalizada orientada para o entendimento. Não se trata, assim, de recuperar fundamentos axiológicos atemporais e abstratos, supraestatais, identificados com uma razão que se manifesta fora da realidade histórica.

Por esse motivo, não faz sentido, para uma teoria democrática do poder constituinte, reestabelecer uma hierarquização entre direito positivo e direito natural, já que a noção de direito natural pressupõe o reconhecimento de conteúdos normativos bons em si mesmos, independentemente de uma deliberação popular que lhes reconheça a importância e a sua exigibilidade. O processo de fundamentação normativa que se faz pela ação do poder constituinte democrático estruturado a partir de uma perspectiva procedimental só garante a validade do conteúdo normativo alcançado, entendida a validade como sua exigibilidade racional, por meio da prova do diálogo, quando todos os potenciais destinatários analisam a proposta e a submetem a argumentos e opiniões livremente lançadas no jogo comunicativo. 
Assim sendo, o direito construído nas bases de um poder constituinte com tais características só se manifesta como direito positivo, como uma imposição estatal, institucionalizada e coercitiva, legitimada pela democracia. Ínsitas na ideia de Direito estão, portanto, a imperatividade e a coercitividade que só se manifestam pela imposição da norma de agir pelo Estado, que também garante o seu cumprimento.

Como uma teoria do exercício do poder popular na democracia, tem-se que a legitimidade pretendida pela ordem jurídica só é possível em estados que se organizam democraticamente, conforme o referencial teórico habermasiano já exposto nos capítulos anteriores. Isso porque só na democracia a garantia da autonomia individual se sustenta, quando os próprios sujeitos atuam tanto como legisladores como destinatários das normas de ação. Por pressupor uma igualdade em direitos de participação e uma dignidade distribuída entre todos os membros da comunidade de parceiros políticos, a democracia é o modo de organização do exercício do poder que garante a institucionalização da razão, entendida, após a reviravolta linguístico-pragmática, como razão dialogal, comunicativa.

Os parceiros políticos reconhecem-se reciprocamente como titulares do poder de criar o direito, numa distribuição igualitária de direitos de participação política e de âmbitos de autonomia individual. Por essa razão, a teoria democrática do poder constituinte é, também, uma teoria que reconhece o poder político como uma manifestação do poder comunicativo, quando há um comprometimento dos sujeitos com a institucionalização da razão.

Ao entender o poder constituinte comunicativamente, é possível reanalisar os postulados tradicionais da incondicionalidade e da ilimitação material. Se a razão se constitui através de um processo de comunicação intersubjetiva, dialogal, tem-se um paradigma que já prevê, em si, limitações, condições de validade analisadas pela filosofia da linguagem. A construção racional de objetos do mundo não é obra de uma razão monológica, isolada, mas resultante de um processo discursivo e participante que põe a todo instante à prova o argumento que deseja se impor. O processo de elaboração racional do direito também está, obviamente, condicionado por tais limitações, por tais exigências de fundamentação, que são determinantes para o exercício do poder constituinte democrático, como se pretende demonstrar adiante. No próximo item, tem-se uma proposta de sistematização dos postulados principais de uma teoria do poder constituinte democrático. 


\subsection{Os postulados do poder constituinte democrático}

No item anterior, pontuou-se que a proposta teórica se define como uma proposta democrática, que considera o direito em sua manifestação positiva e coercitiva, além de conceituar o poder constituinte como manifestação do poder comunicativo, no sentido atribuído pela contribuição teórica habermasiana. O direito nascido do processo constituinte vai refletir um conjunto ordenado de normas de ação, representantes de declarações de reconhecimento de valores instrumentais ${ }^{511}$. A ordem jurídica é, assim, o meio através do qual as decisões soberanas acerca dos valores a serem protegidos na sociedade se tornam concretamente aplicáveis para solucionar conflitos intersubjetivos, isto é, o direito se manifesta como instrumento de ação do estado na mediação das relações sociais.

Neste ponto, tem-se um esforço de sistematização, a partir do qual os postulados teóricos são apresentados em sua unidade à luz dos delineamentos anteriores. Os postulados se referentem às seguintes questões ou características do constituinte: o seu fundamento axiológico; as limitações materiais ao seu exercício; os condicionamentos procedimentais; a identificação do sujeito constituinte. Ao final, serão tematizadas os principais desafios à teoria do poder constituinte democrático, em especial nas democracias recentes da América Latina.

\subsubsection{Fundamentos}

Neste ponto, cabe um esclarecimento de ordem conceitual. O poder constituinte pode ser analisado, de modo geral, a partir de duas perspectivas: sociológica ou normativa. Uma análise sociológica compreende o exercício do poder constituinte como episódio fenomênico, histórico e, por essa razão, único, no sentido de que a teoria deve partir do pressuposto da imprevisibilidade: não é possível determinar, a priori, o que provoca o advento de um processo constituinte e como se dará o seu desenrolar.

\footnotetext{
${ }^{511}$ NIETO, Alejandro. Crítica de la razón jurídica. Madrid: Editorial Trotta, 2007, pg. 42.
} 
A análise sociológica parte, pois, da contigência, do estudo e da interpretação de fenômenos bem situados espacial e temporalmente. Analisa-se a dinâmica do processo constituinte de 1987 no Brasil, por exemplo, entendendo as forças políticas que o movimentaram, os sujeitos históricos principais, as influências ideológicas manifestas nos debates parlamentares, o procedimento empregado para condução dos trabalhos, a crítica da constituição elaborada, etc.

De acordo com Colón-Ríos, o cientista social não está interessado em questões de validade normativa, mas em perceber o nível de eficácia das normas impostas, entendida como obediência daqueles que estão a ela subordinados. Para essa perspectiva, uma norma é legítima e, assim, válida, quando aqueles que estão envolvidos, seja por uma relação de subordinação seja por sua capacidade de as impor, acreditam que ela é legítima ${ }^{512}$.

Nessa perspectiva, o poder constituinte é entendido, na verdade, como uma potência, o que implica ilimitação: uma força social bruta, "enérgica”, capaz de subverter a ordem estabelecida, refundando suas bases. Apesar de ser categorizada como sociológica $^{513}$, essa perspectiva é, na verdade, a base da teoria clássica do poder constituinte, apresentada nos dois capítulos iniciais da tese. É nesse sentido que Tavares, por exemplo, analisa o poder constituinte, preferindo-o chamar de "força ou energia constituinte". Esclarecendo que sua perspectiva não é inteiramente positivista, Tavares salienta que, com essa designação, se indica que não se trata do poder juridicamente posto, mas sim algo que surge de um movimento social ${ }^{514}$. Esse "algo", tomado em sua autonomia e incondicionalidade absoluta, é uma força inteiramente alheia a qualquer teorização prévia.

Ferreira Filho, em sua monografia sobre o tema, identifica a revolução como o veículo do poder constituinte, o transportador, por assim dizer, o instrumento pelo qual se

\footnotetext{
512 COLÓN-RÍOS, Joel I. Weak Constitutionalism: Democratic Legitimacy and the question of constituent power. New York: Routledge, 2012, pg. 104.

${ }^{513} \mathrm{O}$ sentido do termo sociológico aqui empregado não deve ser entendido como "originário da sociologia do direito". Uma teoria sociológica não se presta a estabelecer parâmetros concretos de ação a partir de mandamentos de dever-ser, mas analisa a realidade em sua existência histórica, fenomênica, contigente. Nesse sentido, uma perspectiva sociológica não estabelece os elementos de um poder constituinte ideal, em sentido normativo, mas constitui uma interpertação do poder constituinte tomado empiricamente. Segue essa orientação a análise de Lamounier et ali. Cf. GONZALES E., Juan Jose; LAMOUNIER, Bolívar; MIRANDA, Jorge; NOHLEN, Dieter. El proceso constituyente: experiencias a partir de cuatro casos recientes España, Portugal, Brasil y Chile. In: Cadernos de Direito Constitucional e Ciência Política, Ano I, out.-dez./1992, São Paulo, Revista dos Tribunais, 38-53.

${ }^{514}$ TAVARES, André R. Ibidem, pg. 224.
} 
concretiza a manifestação do poder constituinte ${ }^{515}$. Essa perspectiva, que permeia o discurso da teoria do poder constituinte como um todo, está estreitamente relacionada ao próprio conceito que se tem sobre esse poder: uma força incondicionada, autônoma, original, ilimitada e absoluta.

A perspectiva sociológica é fundamental para a intepretação e compreensão de processos constituintes específicos, mas a redução da análise teórica a uma tal perspectiva pode ser problemática. Se o conceito de poder constituinte depende da perspectiva adotada, reduzir a análise ao plano sociológico implica reconhecer a impossibilidade de estabelecer, ainda que no plano teórico, qualquer tipo de limite para o exercício desse poder. Na medida em que o poder constituinte é a fonte primordial de todo o sistema jurídico, a conclusão lógica é que todo o edifício normativo do direito pode estar sustentado em decisões tomadas com base no arbítrio, numa "energia”, para usar a expressão de Tavares.

Por essa razão, é preciso entender que há uma outra perspectiva teórica que pode ser adotada: a normativa. A perspectiva normativa busca estabelecer as condições ideais para o exercício do poder constituinte e tem a pretensão não de interpretar, mas de orientar os processos constituintes. Para que se sustentasse como teoria - e mais, uma teoria normativa - foi preciso expor os pressupostos filosóficos que definem, de princípio, o paradigma de racionalidade, a noção de poder e de direito que são utilizados para a construção do argumento teórico.

Nesse sentido é que se pode falar em uma teoria normativa do poder constituinte democrático, destinada a definir as condições ideais de seu exercício ${ }^{516}$. É normativa por estabelecer regras, condições, pressupostos que precisam ser observados sempre que o processo constituinte estiver orientado para a democracia, e teoria porque fundamentada filosoficamente à luz de um paradigma de razão.

Em face de tais esclarecimentos, é possível afirmar que o fundamento da teoria do poder constituinte democrático é uma nova compreensão da soberania popular encontrada na teoria habermasiana e que constitui uma releitura de uma intuição fundamental de Kant,

\footnotetext{
${ }^{515}$ FERREIRA FILHO, Manoel G. Direito Constitucional Comparado: O Poder Constituinte. São Paulo: Editora da Universidade de São Paulo, 1974, pg. 40.

516 De acordo com Colón-Ríos, para os partidários de uma perspectiva normativa ou filosófica: political power is legitimate when its rules can be justified acoording to normative principles with which any rational and unbiased person would agree to (COLÓN-RÍOS, Joel I. Weak Constitutionalism: Democratic Legitimacy and the question of constituent power. New York: Routledge, 2012, pg. 104).
} 
ao definir que a liberdade de um só se sustenta com a preservação de igual espaço de liberdade para todos. A soberania é entendida como a fonte do poder, possuído por qualquer unidade política, de se dar Constituição, ou de se autolegislar. O poder constituinte, uma vez que a pressupõe, ao ser realizado, serve de suporte positivo da soberania, instrumentalizando-a ${ }^{517}$.

Uma tensão entre soberania do povo e direitos fundamentais é aparente. Conforme esclarece Kalyvas ${ }^{518}$, observa-se um descrédito do conceito de soberania na teoria política contemporânea, o qual é apontado como um dos principais obstáculos à plena efetividade dos direitos humanos. Habermas oferece uma reinterpretação da relação entre soberania e autonomia privada capaz de reabilitar a soberania como elemento central na teoria da democracia. De acordo com a contribuição habermasiana, há, entre os dois conceitos, uma pressuposição recíproca. Pressupõem-se mutuamente pois a soberania popular, para ser exercida pelo povo enquanto comunidade política unida, precisa ser distribuída igualmente entre os cidadãos, que garantem o direito de participação no âmbito de sua liberdade individual.

Para que cada indivíduo possa manifestar sua vontade, participando ativamente do processo de formação da vontade e da opinião pública, um espaço de liberdade individual - garantido por direitos fundamentais representativos como o direito à vida, à liberdade de opinião e de pensamento, à educação - precisa estar assegurado a priori, de modo que sem igualdade em participação e liberdade não há democracia e, por conseguinte, não é possível falar em soberania popular.

Tais direitos fundamentais, que constituem não uma limitação externa, mas integram o próprio sentido de soberania popular, representam certas necessidades básicas ou genuínas que todos os indivíduos totalmente emancipados teriam; estas necessidades serão necessariamente descobertas por qualquer um que sinceramente participe de um discurso prático. Os princípio de justiça, ou o discurso de fundamentação do direito, são, no dizer de White, uma derivação de tais necessidades ${ }^{519}$.

\footnotetext{
${ }^{517}$ SALDANHA, Nelson. O Poder Constituinte. São Paulo: Revista dos Tribunais, 1986, pg. 67.

${ }^{518}$ KALYVAS, Andreas. Popular sovereignty, democracy, and the constituent power. Constellations, v.12, n. 2, 2005, pg. 223.

${ }^{519}$ WHITE, Stephen K. Razão, Justiça e Modernidade: a obra recente de Jürgen Habermas, tradução de Márcio Pugliesi. São Paulo: Ícone, 1995, pg. 73.
} 
Colón-Ríos também reconhece que certas condições para o exercício do poder constituinte não podem ser abolidas. Ainda que, no plano fático, um processo revolucionário de grandes proporções possa suprimir tais direitos de participação, essa supressão impediria o exercício futuro do poder constituinte, eliminando a possibilidade de uma "reconstituição" democrática. Assim como a democracia, o poder constituinte nega a si mesmo quando viola as condições que o tornam possivel ${ }^{520}$.

Ao servir de fundamento do poder constituinte, a soberania popular condiciona a constituição à institucionalização da democracia, como única opção política em que o poder popular pode se reproduzir livremente, a partir da garantia de certas condições de participação. O constituinte, portanto, ao pretender a legitimação do direito, satisfazendo a força que o fundamenta, precisa perpetuar as condições de exercício futuro do próprio poder de refazer a constituição.

Colón-Ríos estabelece, com razão, que a legitimidade democrática não diz respeito às condições do processo legislativo ordinário, mas aos procedimentos que a constituição estabelece para a sua própria transformação. O sistema normativo, ao se fundamentar, originariamente, na soberania, precisa permanecer aberto ao futuro, às mudanças que a coletividade, conscientemente, através de processos discursivos inclusivos, deseja implementar em seu projeto de vida compartilhado ${ }^{521}$.

De acordo com Saldanha, por ser o constituinte um poder "criador de poder", precisa se constituir como força consciente, historicamente lúcida e responsável, na medida em que as Constituições hoje não são mais formações espontâneas, mas obras reflexas $^{522}$. Isso implica que a fundamentação do poder constituinte na soberania popular uma intuição que remonta às elaborações de Sieyès - tem consequências maiores do que se pode imaginar. Já que o poder constituinte precisa, em última análise, garantir determinadas condições basilares para que a organização política democrática se imponha e se perpetue, os postulados tradicionais da incondicionalidade, autonomia, ilimitação não se mostram plausíveis, pois partem da ideia de que o poder constituinte se apresenta como puro fato social, capaz, hipoteticamente, de tudo, inclusive de eliminar inteiramente as garantias e direitos básicos assegurados na carta constitucional que deseja superar.

520 COLÓN-RÍOS, Joel I. Weak Constitutionalism: Democratic Legitimacy and the question of constituent power. New York: Routledge, 2012, pg. 10.

${ }^{521}$ COLÓN-RÍOS, Joel I. Ibidem, pg. 9.

522 SALDANHA, Nelson. Ibidem, pg. 68. 
Uma alternativa é possível, que vá além de um antagonismo total entre poder político e direito. O poder constituinte precisa ser entendido não apenas em sua dimensão fenomênica, como ocorrência histórica, potência ou energia, mas também como uma expressão de um poder comunicativo fundado na razão dialogal. Entendido como manifestação racional, seus limites serão os limites da própria razão - a mediação linguística, a interação intersubjetiva, a validade obtida pelo assentimento. $O$ poder constituinte não é jurídico porque é através dele que consensos sobre normas de ação se institucionalizam, é, portanto, pré-jurídico, mas não se define apenas como um fato social, pois seu exercício depende da manifestação de interações discursivas racionais, que lhe condicionam.

No item seguinte, tendo em vista tal compreensão sobre os fundamentos do poder constituinte, serão analisados os limites ao seu exercício, entendidos como condições de permanência e preservação da soberania popular.

\subsubsection{Limitações}

Já se pode concluir que a teoria do poder constituinte precisa lidar com um aparente paradoxo, exposto nos seguintes termos:

[...] o ato constituinte é crescentemente capaz de quanta autodeterminação
histórico-política seja possível encontrar num corpo social, é por outro
lado inescapavelmente determinado pelos diversos tipos de circunstâncias
culturais que marcam cada manifestação daquele corpo. Não pode ser um
ato inteiramente livre, de vez que se acha, mesmo, orientado pelas
solicitações partidas das próprias necessidades da comunidade

Ao mesmo tempo em que a soberania popular detém o "poder de criar poder", através da elaboração da constituição, um poder que desconhece qualquer tipo de conformação jurídica, posto que é a força responsável pela própria institucionalização do direito, a autodeterminação política não pode representar um esgotamento, ou mesmo um retrocesso, do espaço de liberdade já conquistado pela comunidade política.

${ }^{523}$ SALDANHA, Nelson. Ibidem, pg. 69. 
Walker e Loughlin, em estudo recente, reafirmam o "paradoxo do constitucionalismo", ao reconhecer que a teoria constitucionalista moderna se estrutura em dois imperativos fundamentais e antagônicos: de um lado reconhece-se que o poder governamental é originado do consentimento do povo, ao mesmo tempo em que se precisa dividir, delimitar esse poder, para que possa ser exercido através de formas institucionais, pois só assim se sustenta e se mostra efetivo ${ }^{524}$.

A partir dessa perspectiva, que vai ao encontro do pensamento habermasiano, o direito atua como medium através do qual a tensão entre validade e facticidade pode encontrar um equilíbrio, já que, ao mesmo tempo em que a forma jurídica representa a construção de um povo investido de soberania, ela delimita, condiciona o modo de exercício do próprio poder.

$\mathrm{Na}$ medida em que o poder constituinte é um poder compartilhado, um poder de criar a constituição que só pode ser exercido pelo grupo (no dizer de Kalyvas ${ }^{525}$, o poder de “co-instituir”), é fundamental que as condições de organização interna deste grupo sejam asseguradas. A ideia de compartilhamento é essencial, pois vincula, de maneira necessária, poder constituinte e democracia, razão pela qual Negri afirma que falar de poder constituinte é falar de democracia ${ }^{526}$.

Os limites que o poder constituinte encontra são os limites que delimitam a fronteira entre a forma democrática de exercício do poder e uma completa supressão da democracia. Embora a teoria do poder constituinte conviva com a possibilidade insuscetível de qualquer controle teórico ou fático - de que um processo de mudança de constituição possa, em tese, culminar na destruição da democracia, é preciso reconhecer o potencial que o poder constituinte carrega para legitimar a ordem instituída através da participação popular no processo de formação da vontade política ${ }^{527}$.

O que Colón-Ríos pretende estabelecer com essa ideia é que o poder constituinte não pode ser compreendido, ainda que seja decorrente de um processo revolucionário, como um completo desastre. Isso porque, de acordo com a visão particular do autor, é na

${ }^{524}$ WALKER, Neil; LOUGHLIN, Martin. The paradox of constitutionalism: constituent power and constitutional form. Oxford: Oxford Press, 2007, pg. 1.

${ }_{525}$ KALYVAS, Andreas. The Basic Norm and Democracy in Hans Kelsen's Legal and Political Theory. In: Philosophy and Social Criticism, v. 32, n. 5, 2006, pg. 589.

${ }^{526}$ NEGRI, Antonio. Insurgencies: Constituent Power and the Modern State. Minneapolis: University of Minnesota Press, 1999, pg. 1.

${ }^{527}$ COLÓN-RÍOS, Joel I. Ibidem, pg. 103. 
possibilidade de futuro exercício do poder constituinte que reside a condição básica da legitimidade democrática ${ }^{528}$.

Como, então, precisar os limites de seu exercício? Em primeiro lugar, é preciso que se compreenda que não se tratam de limites externos, no sentido de que não são imposições hierarquicamente postas por uma força antagônica ao poder popular. Não são limites deduzidos de um direito natural, por exemplo. Em outros períodos da história, as limitações à liberdade de autolegislação foram identificadas como limitações externas fosse o direito divino, fosse a ordem do cosmos - um discurso que foi inteiramente destruído com o advento da Modernidade e a "descoberta" da autonomia tanto filosófica como política do sujeito.

Os limites devem ser entendidos como condições necessárias para o exercício da democracia, onde quer que ela se ponha, seja em que contexto cultural. São constitutivos do modelo democrático, por assim dizer. Tratam-se de necessidades da razão, que se relacionam como o próprio modo através do qual a racionalidade se apresenta perante o sujeito. Em outras palavras, não é possível reproduzir a democracia, confiar em sua estabilidade e permanência, quando o poder constituinte ultrapassar tais limites.

$\mathrm{Na}$ qualidade de imperativos racionais, esses limites não se referem, especificamente, a qualquer cultura política específica. Embora se reconheça que a teoria da democracia é, fundamentalmente, uma teoria do mundo ocidental, a leitura de Habermas permite concluir que ela, a democracia, é, não apenas uma conquista histórica de um povo, mas a forma básica de organizar o poder quando se pretender o uso da razão, o que transcende, portanto, o aspecto cultural. Embora a dinâmica do poder seja variável e dependa diretamente do seu exercício concreto, à luz de um espaço-tempo bem definido, as condições racionais para a institucionalização da democracia, no contexto de uma teoria normativa do poder constituinte, apresentam-se como universais.

Feito esse esclarecimento, é possível pontuar alguns limites, deduzidos tanto da contribuição teórica habermasiana, como da definição do poder constituinte como poder comunicativo. São eles: a) o espaço individual de autonomia do sujeito, entendido como espaço de autodeterminação livre de interferências estatais; b) o reconhecimento recíproco da igualdade e a garantia do direito de participação política; c) as condições

${ }^{528}$ COLÓN-RÍOS, Joel I. Op. cit. 
para o gozo de uma vida plena em sociedade; d) a preservação e a permanência de uma esfera pública pluralista e inclusiva; e) a possibilidade de se invocar o exercício do poder constituinte; f) a proibição do retrocesso.

De acordo com a ideia defendida, o poder constituinte é democrático na medida em que respeita tais limitações, as quais constituem "um resgate moral" da relação entre direito e política nas democracias recentes, em especial. É preciso esclarecer cada uma das categorias elencadas.

\subsubsection{Autonomia individual}

Conforme entende Habermas, há uma relação de co-originariedade entre autonomia pública e privada. Essa relação é que explica a existência de um nexo entre soberania popular e direitos humanos ou fundamentais. Um não pode existir sem o outro, isso porque é através do exercício da soberania que as formas de comunicação - necessárias para uma vida autônoma - podem ser institucionalizadas juridicamente. A autonomia do sujeito existe em face de sua condição de sujeito político, de participante de um processo discursivo através do qual as normas podem encontrar assentimento de todos os possíveis $\operatorname{atingidos}^{529}$.

Se a autonomia individual é indispensável para o exercício da soberania, o poder constituinte não pode ser exercido de modo a suprimi-la ou a reduzir de forma sensível o espaço de liberdade individual, pois esse exercício implicaria uma verdadeira negação do próprio conceito do poder de autolegislação identificado na soberania do povo. Esclarece o filósofo alemão:

Através do medium de leis gerais e abstratas, a vontade unificada dos cidadãos está ligada a um processo de legislação democrática que exclui per se todos os interesses não-universalizáveis, permitindo apenas regulamentações que garantem a todos as mesmas liberdades subjetivas. De acordo com esta ideia, o exercício da soberania do povo, conforme o

\footnotetext{
${ }^{529}$ HABERMAS, Jürgen. Direito e Democracia: Entre Facticidade e Validade, v. I, tradução de Flávio
} Siebeneichler, 2 edição. Rio de Janeiro: Tempo Brasileiro, 2012, pg. 138. 
procedimento, garante também a substância do direito humano originário, delineado por Kant ${ }^{530}$.

É preciso compreender, então, o que se entende por espaço de autonomia individual. A noção de autonomia pode ser entendida no sentido kantiano, como capacidade de autodeterminação racional. Esse "espaço", por assim dizer, é constituído a partir de possibilidades de ação ou omissão disponíveis ao indivíduo, que opta por exercêlas a partir de seu interesse e avaliação. Aquilo que os sujeitos podem efetivamente realizar independentemente da autorização do outro é o que constitui, portanto, o seu espaço de autonomia individual.

A autonomia individual é assegurada por meio de diversas pretensões normativas, que ganham contornos mais concretos e exigibilidade com o processo de positivação constitucional. É possível dizer que o feixe de liberdades públicas forjadas pelo liberalismo clássico é o cerne da autonomia individual: o direito à vida; a liberdade de expressão e de pensamento; o direito à propriedade privada; as garantias processuais relacionadas à inafastabilidade do controle jurisdicional e ao devido processo legal; os direitos de personalidade, tais como o direito à imagem e à privacidade, etc.

Tratam-se de direitos pressupostos que asseguram a autonomia e permitem que o indivíduo possa transitar livremente entre o público e o privado, sem prejuízo de sua capacidade de autodeterminação. O espaço de autonomia é, assim, intangível ao constituinte, ainda que seja pela sua ação que esse espaço se constitua como pretensões exigíveis em face do Estado e dos demais indivíduos.

A institucionalização através do direito positivo atua, para usar a expressão habermasiana, como o medium por meio do qual a autonomia deixa de ser um postulado de natureza moral, uma condição racional para democracia, e se transforma em norma legal, caracterizada pela imperatividade e a coercitividade. De acordo com o argumento que se põe, o processo constituinte democrático precisa, necessariamente, não só ser conduzido em conformidade com tais expectativas normativas referentes à proteção da autonomia individual, mas deve positivá-las na forma jurídica, como imperativos tutelados pelo poder de sanção, inerente à coercitividade própria do direito.

${ }^{530}$ HABERMAS, Jürgen. Ibidem, pg. 136. 


\subsubsection{Igualdade e participação Política}

O trabalho do poder constituinte é uma práxis compartilhada. Kalyvas, rementendo ao sentido etimológico do verbo constituir, esclarece que a constituição é o produto de um trabalho realizado em conjunto, um "co-estabelecimento" de um ato normativo fundamental. A soberania é um poder difuso, no sentido de que é titularizado por um corpo de indivíduos componentes de uma unidade a que se dá a denominação genérica de "povo". Por esse motivo, o autor explica que é inerente ao termo "constituir" a sua relação com a democracia, já a estrutura semântica da palavra indica inclusão, reciprocidade e participação $^{531}$.

Sendo a soberania popular a fonte do poder constituinte, é uma inferência lógica que seu exercício deve ser condicionado pelo respeito ao princípio da igualdade originária entre todos os membros da comunidade política, em um processo de inclusão radical. O poder constituinte não pode, assim, no ato constituinte, criar qualquer limite normativo ao reconhecimento intersubjetivo da igualdade, que se apresenta como uma manifestação da dignidade humana, em sua dimensão moral. A igualdade fundamental entre todos os indivíduos, no sentido normativo, é condição prévia para o funcionamento e para a reprodução de qualquer organização democrática.

O postulado da igualdade é, também, uma consequência da institucionalização do poder comunicativo, já que, de acordo com o paradigma da racionalidade dialogal, a validade das normas é resultante de um processo discursivo através do qual todos os potenciais atingidos pela norma podem manifestar o seu assentimento. Esse o sentido do procedimentalismo democrático. O processo discursivo pressupõe, assim, relações de reciprocidade, por meio das quais o "eu" conhece no "outro" um igual em condições de debate e de participação.

O princípio da igualdade é utilizado, pela teoria da democracia, para identificar como os indivíduos se relacionam entre si no espaço público. Se há, a priori, um reconhecimento da igualdade entre todos, é fundamental que se garanta o direito de participação nos mais diversos processos de deliberação política. A inclusão política é entendida, assim, como uma decorrência do exercício da soberania popular. Por inclusão, é

${ }^{531}$ KALYVAS, Andreas. Ibidem, pg. 588. 
possível entender tanto o direito a escolher representantes parlamentares, como a possibilidade de contribuir para o debate na esfera pública, manifestando opinião e apresentando argumentos.

Embora não seja possível pensar na democracia, hoje, sem a figura da representação, pode-se abrir canais de deliberação e diálogo com a sociedade civil que tornem mais participativos os processos deliberativos oficiais. Tratam-se de mecanismos de participação direta que podem complementar, legitimando, as decisões tomadas nos espaços oficiais do estado, tais como o referendo, o plebiscito, o veto popular, ou, em um nível ainda mais original, a iniciativa popular de projeto de lei.

O poder constituinte é limitado, também, pelo princípio da igualdade e pelo direito de participação, os quais são condições necessárias para a estabilização de qualquer ordem democrática legitimamente instituída.

\subsubsection{Gozo da vida plena}

Não é possível pensar em autonomia individual e em igualdade ou participação sem a garantia das condições efetivas de gozo de uma vida plena, entendida em sua manifestação social ou cultural. A plenitude só pode ser compreendida em face das prestações sociais que instrumentalizam o desenvolvimento da personalidade do indivíduo, o desenvolvimento de sua capacidade de autodeterminação. Uma vida é considerada plena quando estão satisfeitas as exigências de formação educacional, de acesso à saúde e à moradia, garantia de lazer e gozo da cultura, o respeito por relações de trabalho digno. A capacidade de avaliação e decisão, expressões da liberdade individual, depende do gozo da vida plena.

Nesse sentido, volta-se à contribuição de Sen e ao seu sentido de desenvolvimento humano. Para o autor, a liberdade individual depende do que as pessoas podem efetivamente realizar em sua vida pública. O que se pode, como cidadão, fazer é influenciado por oportunidades econômicas, liberdades políticas, poderes sociais e por 
condições habilitadoras como boa saúde, educação básica e incentivo e aperfeiçoamento de iniciativas ${ }^{532}$.

Enquanto grupo comprometido com realização da democracia e interessado na preservação da autonomia individual, não é possível à sociedade desconsiderar a necessidade de concretização de prestações sociais "habilitadoras", especialmente em países marcados por baixos índices de desenvolvimento, como o Brasil. O constituinte está, assim, condicionado a tutelar tais expectativas, manifestas na forma de direitos sociais, garantias institucionais e de programas concretos de ação.

É por isso que as constituições da América Latina têm um teor fortemente dirigente, pois as condições reais de participação na vida pública restam severamente prejudicadas pelos altos índices de desigualdade social. A igualdade, para se afirmar como base de uma organização social, só se converte em realidade quando distribuída não apenas como uma garantia formal, mas, sobretudo, como poder concreto de ação.

A constituição brasileira vigente é bastante representativa de um modelo constitucional marcado pelo compromisso de mudança. Ela pode ser vista não apenas como uma carta de direitos em seu sentido clássico, mas como um projeto ousado de transformação social. Ainda que se possa questionar a efetividade no atendimento de seus programas de ação, é possível reconhecer em sua identidade uma determinada visão de sociedade e estado estreitamente relacionada à democracia.

É possível, à luz da limitação que se explica neste item, questionar a legitimidade de iniciativas de mudanças tendentes a suprimir da constituição direitos e garantias sociais, sob o argumento de uma incapacidade do estado para prover a sociedade em suas necessidades mais variadas. $\mathrm{O}$ enxugamento da máquina estatal promovido por movimentos reformadores, ao tocar no núcleo essencial de uma concepção de poder e de sociedade, pode implicar em déficit de legitimidade.

Aqui também cabe uma digressão a fim de se tematizar os limites não apenas do constituinte originário, mas também no chamado poder de reforma, ou poder constituinte reformador. Uma dúvida que se põe na interpretação da constituição brasileira vigente diz respeito ao caráter de cláusula pétrea dos chamados direitos de segunda dimensão ou

${ }_{532}$ SEN, Amartya. Desenvolvimento como liberdade, tradução de Laura Motta. São Paulo: Cia das Letras, 2000, pg. 19. 
direitos sociais. Na medida em que a constituição, em seu artigo 60, não incluiu textualmente no seu núcleo intangível tais direitos, restringindo o texto aos direitos e liberdades individuais, há quem sustente a possibilidade de emenda constitucional no sentido de suprimi-los.

Esse argumento não se mostra plausível por algumas razões. Em primeiro lugar, a leitura das cláusulas pétreas não pode estar restrita ao aspecto puramente literal das palavras empregadas pela assembleia constituinte. Atecnias legislativas e imprecisões terminológicas são encontradas não só na constituição, mas no farto material legislativo produzido diariamente pelo estado. A norma não pode ser identificada com o texto, na medida em que o seu sentido também abarca a compreensão sistêmica de toda a carta constitucional, em seus princípios e objetivos fundamentais.

Também não pode prosperar o argumento pelo caráter essencial de tal categoria de direitos ou pretensões normativas. Como se busca demonstrar neste item, o direito ao gozo de uma vida plena é uma condição estruturante da democracia, sem a qual sua permanência e estabilidade não são possíveis, razão pela qual uma constituição que se apresenta como democrática não pode tolerar, do ponto de vista normativo, qualquer reforma que permita uma supressão de garantias instrumentais à conquista da autonomia individual. Desse modo, à luz da proposta teórica que se apresenta, mesmo que não haja no texto a previsão, como cláusula pétrea, dos direitos sociais, sua intangibilidade é um imperativo de ordem racional.

\subsubsection{Estabilidade da esfera pública pluralista e inclusiva}

As limitações que se apresenta ao poder constituinte dialogam entre si, sendo complementares. Nesse sentido é que, para garantir o direito de participação e a capacidade de autodeterminação, a estabilidade de uma esfera pública pluralista e inclusiva é um imperativo. O sentido de esfera pública como canal de diálogo entre sociedade civil e estado é indicativo da importância desse conceito para a teoria da democracia.

As organizações democráticas contemporâneas são fortemente dependentes da figura da representação parlamentar, o que pode criar um hiato entre a decisão tomada nos 
processos de deliberação oficial e a opinião/vontade pública. O fortalecimento da esfera pública pode ser uma saída capaz de resolver esse impasse, já que cria espaços de discussão e de participação não oficiais, mais fluidos e inclusivos.

A limitação se manifesta na forma de um dever de preservação: não é possível ao poder constituinte, através dos atos de criação da constituição, criar impedimentos institucionais ou jurídicos tanto ao acesso como à reprodução da esfera pública e, aqui, especialmente, é sensível a proteção à liberdade de imprensa e de pensamento.

A análise de Häberle sobre o problema da interpretação constitucional busca oferecer uma "contribuição para a interpretação pluralista e procedimental da constituição". A tese fundamental do autor se manifesta na forma de um imperativo: para garantir uma mudança na hermenêutica constitucional é preciso promover uma passagem de uma sociedade restrita para uma sociedade aberta de intérpretes da constituição. De acordo com Häberle:

\begin{abstract}
Propõe-se, pois, a seguinte tese: no processo de interpretação constitucional estão potencialmente vinculados todos os órgãos estatais, todas as potências públicas, todos os cidadãos e grupos, não sendo possível estabelecer um elenco cerrado ou fixado com numerus clausus de intérpretes da Constituição ${ }^{533}$.
\end{abstract}

A tese do constitucionalista alemão manifesta uma preocupação importante: a criação de canais de discussão e debate sobre os problemas constitucionais fora dos espaços formais de interpretação da constituição. Essa contribuição teórica é importante para demonstrar que a existência de uma sociedade aberta e pluralista é uma condição de efetividade da constituição, manifesta através dos processos interpretativos, que atualizam e transformam as normas constitucionais em realidade efetiva.

A participação plural no processo de interpretação é, para Häberle, uma fonte de legitimação no processo constitucional. Desse modo, o fortalecimento e a estabilização de uma esfera pública pluralista e inclusiva está no cerne de uma teoria procedimental da democracia. Segundo Häberle:

Constitucionalizar formas e processo de participação é uma tarefa específica de uma teoria constitucional (procedimental). Para conteúdos e métodos, isto se aplica de forma limitada. Fundamentalmente, o processo político deve ser (e deve permanecer), tanto quanto possível, aberto,

\footnotetext{
${ }^{533}$ HÄBERLE, Peter. Hermenêutica constitucional. Sociedade aberta dos intérpretes da constituição: contribuição para a interpretação pluralista e "procedimental" da constituição, tradução de Gilmar Ferreira Mendes. Porto Alegre: SAFE, 2002, pg 13.
} 
devendo também uma interpretação "diversionista" ter oportunidade de ser sustentada, em algum momento" ${ }^{\text {"3 }}$.

À luz das palavras de Häberle, pode-se concluir que a manifestação do direito de participação política, um direito estruturante de qualquer organização democrática, é manifesto também quando o sujeito pode participar dos processos de interpretação da constituição, fazendo parte de uma "sociedade aberta de intérpretes". Essa condição de legitimidade reflete-se no dever de preservação da esfera pública, enquanto espaço fluido e informal onde as questões sobre as normas constitucionais - desde a sua gênese até a sua aplicação - podem ser construídas discursivamente.

\subsubsection{Permanência do poder constituinte}

O poder constituinte não se esgota no ato constituinte, na medida em que ele é expressão de uma vontade popular soberana. Subsiste, como potência, e é capaz de atuar sempre que haja um descompasso entre a expectativa normativa compartilhada e o direito positivado.

A eliminação do poder constituinte tem consequências que foram expostas por Negri em sua proposta teórica. De acordo com o autor, o poder constituinte precisa ser mantido uma vez que sua eliminação pode anular o verdadeiro sentido do sistema jurídico e da relação democrática que deve caracterizar o seu horizonte ${ }^{535}$. Entendida como poder radical de autodeterminação, a ideia de democracia não tolera, do ponto de vista lógico, a extinção da capacidade de modificar o fundamento de validade da ordem jurídica pela mudança de constituição.

A relação necessária entre poder constituinte e democracia é capaz de justificar sua permanência como uma condição necessária de sua manifestação: o poder constituinte não pode, através do ato constituinte, negar a si mesmo, "fechando" a ordem jurídica às futuras transformações constitucionais. O futuro, assim, permanece aberto, a não ser quanto às condições fundamentais para o próprio exercício da democracia.

\footnotetext{
${ }^{534}$ HÄBERLE, Peter. Ibidem, pg. 55.

${ }^{535}$ NEGRI, Antonio. Insurgencies: Constituent power and the modern state. Minneapolis: University of Minnesota, 1999, pg. 3.
} 
O poder constituinte se manifesta como uma força expansiva e violenta e representa a preconstituição social da totalidade democrática ${ }^{536}$. Sua existência, ou seu exercício, são determinantes para a institucionalização da democracia a partir da estruturação do sistema político.

A democracia, tomada em sua qualidade de modelo de organização social, passa por reconstruções e ressignificações ao longo da experiência política de um povo, as quais podem induzir a um "chamado" pelo processo constituinte, enquanto momento de reflexão compartilhada sobre as bases jurídicas em que se assenta o projeto político comum. Nesse sentido é que se afirma não haver uma estabilidade total da ordem constitucional criada pelo exercício do poder constituinte.

A permanência (ou latência) do poder constituinte é o resultado lógico do reconhecimento de que a estabilidade do direito legislado não é eterna. A norma positivada, ainda que passe por atualizações decorrentes do processo interpretativo, se esgota em seu sentido, exigindo uma transformação em dimensão mais fundamental: uma mudança na própria percepção dos valores a serem tutelados pela ordem jurídica que se reflete em uma mudança concreta no próprio texto positivado. Como manifestação de um poder de autodeterminação, a constituição só permanece legítima enquanto contar com o assentimento racional dos destinatários-legisladores.

Por tais razões, o postulado da continuidade temporal constitui uma limitação intrínseca ao exercício do poder constituinte.

\subsubsection{Proibição do retrocesso normativo}

O direito positivado é entendido, conforme salienta Saldanha ${ }^{537}$, como uma construção, um objeto cultural, marcado pelos significados forjados na história. A identificação dos valores pelo grupo, a construção de seu sentido, a relevância que as expectativas normativas adquirem na sociedade constituem uma forma concreta de entender o mundo e, em especial, de estabelecer a relação entre estado e sociedade.

\footnotetext{
53610

${ }^{537}$ SALDANHA, Nelson. O Poder Constituinte. São Paulo: Revista dos Tribunais, 1986, pg. 26.
} 
As normas jurídicas são constitutivas, portanto, de uma herança cultural, que pode representar, objetivamente, avanços na proteção do âmbito de liberdade individual e no acesso às condições para o gozo de uma vida plena, quando o sujeito dispõe de todas as condições materiais para o seu desenvolvimento pessoal. $\mathrm{O}$ rol de direitos fundamentais faz parte de um discurso teórico que pode elucidar o sentido cultural que se quer atribuir ao direito positivado pelo constituinte: os direitos fundamentais constituiriam uma "afirmação histórica" ${ }^{\text {538 }}$, uma conquista moral da humanidade.

De acordo com essa perspectiva, os direitos humanos - positivados num plano não apenas doméstico, mas supranacional - representariam conteúdos inteiramente intangíveis ao constituinte originário, na medida em que integram um espaço já conquistado e reconhecido internacionalmente pela comunidade de povos. É preciso entender o argumento com cuidado, pois a conclusão parte do pressuposto de que existem conteúdos bons em si mesmos, representativos de limitações transcendentes em relação ao próprio exercício do poder, próximas da ideia de um direito natural.

Embora se possa reconhecer que os direitos humanos foram positivados progressivamente, seguindo o próprio curso do desenvolvimento político das sociedades ocidentais, a enumeração dos direitos e mesmo a sua efetivação acompanham as diversidades culturais e constituem interpretações contextuais de valores semelhantes, como a vida, a propriedade e mesmo a liberdade. De todo modo, quando determinada norma - seja ela uma permissão ou uma proibição - se impõe como fruto de um reconhecimento intersubjetivo de sua validade, ela passa a integrar uma determinada eticidade, a visão de mundo compartilhada, sendo problemática a supressão do nível civilizatório já alcançado pela sociedade.

O princípio da proibição do retrocesso social estabelece um limite ao poder de disposição sobre a ordem jurídica, no sentido de que o grau de proteção já conquistado não pode ser desconsiderado pelo constituinte e, também, pelo legislador infraconstitucional. Essa conclusão não constitui uma violação ao princípio democrático, na medida em que a compreensão de soberania popular exposta no trabalho precisa conviver com a preservação do espaço de autonomia individual, considerados complementares, reciprocamente considerados.

\footnotetext{
${ }^{538}$ COMPARATO, Fábio Konder. A Afirmação Histórica dos Direitos Humanos, $7^{\mathrm{a}}$ edição. São Paulo: Saraiva, 2010.
} 
Retomando o argumento, qualquer retrocesso normativo quanto às liberdades individuais e sociais já conquistadas inviabilizam o próprio exercício da democracia direta, por esgotar a capacidade de autodeterminação necessária à participação nos processos de deliberação pública. Por essa razão, a proibição do retrocesso normativo constitui um limitação ao exercício do poder constituinte, entendido, ele também, como manifestação da cultura de um povo.

Exercido à luz de uma realidade cultural concreta, em um espaço-tempo definido, o poder constituinte não goza de uma originariedade total, isto é, ele refaz a constituição no bojo do desenvolvimento de uma experiência constitucional já iniciada, com sentidos e instituições experimentadas e conhecidas, e que, muitas vezes, como no caso brasileiro, subsistem mesmo após a mudança no parâmetro último de validade representado pela constituição. $\mathrm{Na}$ medida em que o direito, ao pretender a validade racional, precisa se afirmar como um imperativo justificado pelo procedimento democrático, ele não pode simplesmente desaparecer, como realidade positiva, à revelia de um processo reflexivo de deliberação que considere a necessidade de tal supressão.

\subsubsection{Sujeito constituinte}

Ao analisar os postulados da teoria do poder constituinte, é preciso enfrentar o questionamento sobre a identidade do sujeito constituinte. Em outras palavras, em quem repousa a autoridade para elaborar a nova carta, conduzindo o processo de elaboração da carta constitucional?

Seguindo a orientação conceitual de Saldanha, reconhece-se que o constituir-se, correspondente à nação, indica a existência (na qual repousa) de uma competência básica de decidir sobre a estrutura da Constituição; há que atribuir a algo a qualidade de suporte da capacidade de fazer a organização constitucional do país ${ }^{539}$. Desse modo, entendendo a constituição enquanto construção, em sua concretude positiva, há que se conferir a tal "suporte institucional" a atribuição de promover os atos constituintes, um suporte

${ }^{539}$ SALDANHA, Nelson. Ibidem, pg. 73. 
institucional que, em sociedades de maior complexidade, conduz o processo constituinte em si mesmo considerado.

O constituinte tem a tarefa árdua de precisar os limites da constituição, definindo os valores, instituições, direitos e garantias a serem tutelados. Essa tarefa é constitutiva de uma identidade normativa que gera reflexos em toda a ordem jurídica. Rosenfeld reconhece a dificuldade de se precisar a identidade do sujeito constitucional, já que seria mais acurado considerá-lo uma ausência mais que uma presença. A constituição, ao assumir escolhar axiológicas principais, precisa construir sua identidade em eposição às outras eticidades difundidas do meio social, na medida em que ela não pode sobreviver a não ser que permaneça distinta dessas últimas ${ }^{540}$.

Ao mesmo tempo que, pela constituição, as decisões fundamentais se impõem, negando as demais identidades, é preciso que, enquanto norma, ela permaneça aberta, criando um processo de reconstrução orientado no sentido de alcançar um equilíbrio entre a assimilação e a rejeição das demais identidades. É por esse motivo que a tarefa do constituinte precisa dar conta dessa "abertura", pois a democracia exige um conceito de constituição entendida como um "processo dinâmico sempre aberto à maior elaboração e à revisão" "541.

Para identificar o sujeito constituinte é preciso distingui-lo do soberano. A figura da representação parlamentar é, nos modelos democráticos contemporâneos, não só uma opção, mas um elemento constitutivo, de modo que o processo de gênese normativa passa, necessariamente, pela ação de mandatários subordinados à ratificação do titular da soberania.

Por uma questão de lógica conceitual, o titular do poder constituinte há de ser, antes de tudo, correspondente - ao menos em sentido formal - ao da soberania ${ }^{542}$. Desse modo, o poder constituinte é um poder de fonte popular, um poder titularizado pelo povo. Materialmente, o poder constituinte não tem condições de ser exercido diretamente por uma coletividade de milhões. O sujeito constituinte é a instituição responsável pela feitura da constituição escrita, quando se tem a passagem da norma, em sua manifestação abstrata,

\footnotetext{
${ }^{540}$ ROSENFELD, Michel. A Identidade do sujeito constitucional, tradução de Menelick de Carvalho Neto. Belo Horizonte: Del Rey, 2003, pg. 27.

${ }^{541}$ ROSENFELD, Michel. Ibidem, pg. 23.

${ }^{542}$ SALDANHA, Nelson. Op. cit.
} 
para o texto normativo, um comando imperativo, positivo e manifesto, pronto para ser aplicado nos espaços institucionais do estado e submetido à interpretação.

Uma vez que o modelo de razão é dialogal, e se baseia na intersubjetividade, o sujeito constituinte assume a forma, necessariamente, de um corpo colegiado, de formação plural, de tal modo que possa captar e filtrar as diversas demandas e argumentos manifestos na esfera pública central e nas esferas públicas periféricas. A decisão sobre como compor esse corpo, que constitui o ato constituinte fundamental e primário, precisa ser tomada diretamente pelos titulares da soberania se o objetivo for a preservação do princípio democrático.

Um modelo normativo sobre o poder constituinte precisa atentar para os procedimentos indispensáveis à preservação da democracia desde momento de elaboração da constituição. O processo constituinte, sua sequência de atos, há de passar pelos seguintes passos, uma sequência lógica do processo decisório tomado à luz do modelo democrático: a) a consulta popular sobre a decisão de deflagrar o processo constituinte; b) a eleição direta dos representantes que irão compor a assembleia constituinte; c) a ratificação popular do texto preparado pelos membros eleitores.

O primeiro passo diz respeito à decisão fundamental de invocar o exercício do poder constituinte originário, iniciando um movimento de subversão da ordem constitucional, com a perda de vigência de uma carta e a positivação de um novo conjunto normativo. Essa decisão não pode estar reduzida ao espaço parlamentar, pois a autodeterminação se afirma, aqui, em sua feição mais primária, não cabendo a delegação por mandato. Por isso, cabe ao parlamento, ou ao chefe do executivo, a depender da experiência constitucional específica, invocar a consulta popular sobre a pertinência de se iniciar a constituinte.

O questionamento básico a ser diretamente enfrentado pelo povo é: a mudança da constituição representa a vontade nacional? A resposta positiva é representativa de uma transformação no projeto de vida compartilhado, o qual deixa de encontrar ressonância com a carta constitucional positivada. Sem reconhecer o fundamento básico da ordem jurídica como uma manifestação de sua capacidade de autodeterminação, a mudança da constituição se afirma, assim, como uma expressão da soberania, uma consequência do descontentamento popular em relação ao direito. 
A consulta sobre a deflagração da constituinte se insere nos restritos espaços em que a democracia é exercida diretamente pelo povo. Processos constituintes que são iniciados pela decisão unilateral de representantes parlamentares, tal como o que se observou no Brasil na década de 60 do século XX, podem ser entendidos como ilegítimos, na medida em que partem do pressuposto de que os destinatários das normas estão excluídos desse nível de deliberação, o que anula o princípio democrático.

À semelhança de um processo eleitoral ordinário, a consulta popular sobre a deflagração do processo constituinte precisa ser precedida de um tempo mínimo para que os canais de discussão e formação da vontade pública possam promover processos discursivos que, de diversos modos, servem para esclarecer, num processo reflexivo gestado na sociedade pela sociedade, o que representa a decisão a ser tomada e quais são as suas consequências para o exercício do poder político. É por isso que a democracia, para se reproduzir e fortalecer, necessita de um nível de estabilidade não só institucional como social, quando o grupo consegue internalizar o conflito e as tensões sociais em canais de diálogo e discussão, simbolizados pela renovação da ordem jurídica promovida com a mudança de constituição.

A promoção de consultas populares sobre o processo constituinte em períodos de instabilidade política pode ocasionar um grave risco à permanência das instituições democráticas. A experiência histórica mostra que boa parte dos regimes autoritários implantados na América Latina no século XX aproveitaram-se de períodos de crise para justificar mudanças na organização do poder tomadas independentemente de particição popular. Para que a formação da vontade aconteça racionalmente, é preciso garantir os pressupostos de exercício do poder constituinte, os quais são diretamente dependentes de estabilidade.

Com isso se tenta desvincular a prática do poder constituinte de uma falsa ideia, que o associa à crise e à revolução violenta. Trata-se da ideia de que a crise constitucional só tem por consequência necessária uma completa subversão da ordem estabelecida e uma instabilidade generalizada que alcança os mais diversos níveis de organização social. Se se compreender a democracia como um modelo de organização política que permite avanços e transformações no próprio modo como a sociedade se compreende e deseja se conduzir a si mesma, é possível pensar na mudança constitucional em seu sentido positivo, como um 
passo no sentido de uma reprodução da própria democracia e da afirmação da soberania popular em seu nível mais profundo.

O resultado positivo da consulta sobre a deflagração da constituinte deve iniciar uma nova fase no processo de mudança, referente às candidaturas e à eleição dos representantes parlamentares que serão responsáveis pela preparação do texto da constituição. Aqui, também, o exercício da democracia se apresenta como popular e direto, pois a legitimidade depende da identificação - inclusive no nível pessoal, personificado entre constituintes e povo. Neste ponto, a preservação da esfera pública se afirma como uma limitação importantíssima ao exercício do poder constituinte, pois tanto o processo de escolha dos mandatários como a sua futura atuação precisam constituir uma mediação entre sociedade civil e estado construída nos espaços livres da esfera pública, para além dos espaços formais.

A imprensa livre, a liberdade de pensamento e de opinião são determinantes para a existência de um debate informal promovido nos espaços de discussão da sociedade civil, representativos da esfera pública. Esse debate, ao ser filtrado pelos sujeitos constituintes, é capaz de criar uma ressonância, garantindo que o texto aprovado pela assembleia constituinte seja o reflexo dos consensos construídos discursivamente pelos potenciais atingidos pelas normas constitucionais.

Com a conclusão dos trabalhos da assembleia constituinte, tem-se a necessidade de uma ratificação popular, ponto que determina, materialmente, a passagem da decisão política ao direito positivado. Conforme esclarece Lenowitz, talvez a mais intuitiva justificação para a ratificação consiste no apelo ao poder constituinte. Com isso, se reconhece que constituições devem ser ratificadas porque o povo é a única fonte da soberania e somente com sua explícita aceitação a constituição pode garantir autoridade $^{543}$. A aprovação simbolizada pela ratificação também precisa ser decorrente de um exercício direto do direito à participação política.

Uma vez operada a ratificação, a que Lenowitz define como o "segundo momento do poder constituinte", só é possível estabelecer legitimamente uma mudança na ordem constitucional se respeitados os passos que lhe antecedem, a partir de uma nova invocação

\footnotetext{
${ }^{543}$ LENOWITZ, Jeffrey. Why ratification? Constituent power and the unexamined procedure. In: CAYLA,
} Olivier; PASQUINO, Pasquale. Le pouvoir constituant et l'Europe. Paris: Dalloz, 2011, pg. 14. 
do poder constituinte originário. Reinicia-se o processo do início, em respeito ao procedimento democrático.

O exercício concreto do poder constituinte não esgota suas potencialidades de mudança, já que nenhuma carta constitucional tem o poder de "fechar o futuro", inviabilizando a reprodução da democracia pela mudança da ordem constitucional. Nesse sentido, Rosenfeld afirma que no contexto de uma constituição viva, de uma living constitution, a identidade constitucional é o produto de um processo dinâmico sempre aberto à maior elaboração e à revisão ${ }^{544}$.

O respeito a esses passos é uma condição de permanência da democracia, pois assegura que todo o processo decisório se submete ao assentimento dos destinatários das normas, que se reconhecem, a partir da manifestação direta de sua concordância, também como autores da ordem jurídica estabelecida.

Cabe uma ponderação importante, que remete à clássica distinção entre poder constituinte derivado e poder constituinte originário. Uma vez posta a constituição, o poder reformador - exercido indiretamente pelos representantes parlamentares - é rigorosamente limitado pela constituição. Não constitui, essa limitação, uma ofensa à soberania, já que o próprio soberano define condições de permanência do texto positivado, simbolizadas na forma de: a) procedimentos formais e rígidos de mudança, os quais não podem ser, eles mesmos, alterados pelo poder reformador; b) cláusulas pétreas que estão fora do espaço de deliberação permitido ao poder legislativo, constitutivas do chamado "núcleo essencial" da constituição.

Existem diferenças fundamentais entre o nível de discussão empreendido pelo poder constituinte originário - que implica uma autocompreensão pela sociedade da mudança constitucional como uma urgência que demanda o comprometimento e o exercício da democracia direta - e aquele cotidianamente observado na prática do poder reformador. Tratar a decisão sobre as mudanças na base do sistema político no âmbito do poder reformador é excluir o soberano do exercício de sua capacidade de autodeterminação. Nesses casos, a jurisdição constitucional pode ser um importante aliado na preservação do princípio democrático e da soberania popular, ao garantir que os

\footnotetext{
${ }^{544}$ ROSENFELD, Michel. A Identidade do sujeito constitucional, tradução de Menelick de Carvalho Neto. Belo Horizonte: Del Rey, 2003, pg. 23.
} 
pressupostos para o exercício do poder constituinte, suas limitações intrínsecas, sejam respeitados.

\subsection{Os desafios da teoria do poder constituinte}

A conclusão da tentativa de sistematização de uma teoria propositiva sobre o poder constituinte democrático precisa enfrentar seus desafios e suas maiores dificuldades para que permaneça sustentável. Tentar teorizar a mudança exige, também, uma constante renovação da própria teoria, que tem, com a práxis, uma relação dialética clara de negação e afirmação que se põe através da experiência histórica. Por isso, a conclusão do trabalho deve indicar caminhos através dos quais a discussão possa prosseguir, ampliando ainda mais o espaço de discussão sobre o tema enfrentado.

Para tematizar os desafios da teoria do poder constituinte hoje é preciso ter em mente que a proposta teórica de um poder constituinte democrático como expressão de uma razão comunicativa se ampara em mudanças de ordem filosófica ainda não inteiramente claras e difundidas na literatura e no meio científico. Análises teóricas mais conservadoras, restritas a uma visão de positivismo jurídico que não tematiza o problema da fundamentação, convivem com propostas interdisciplinares para os problemas da teoria do direito, os quais buscam recursos da psicologia, da filosofia e da sociologia para dar compreender o verdadeiro sentido da relação entre direito e poder.

A percepção do discurso constitucional como modalidade especial de manifestação da razão comunicativa já pode ser encontrada em estudos recentes, como aquele de Michel Rosenfeld sobre a identidade do sujeito constitucional. Em seu texto, o professor apresenta o sujeito constitucional não como uma identidade concreta, perfeitamente identificável, mas como comunidade plural de participantes de processos discursivos que têm, como pano de fundo, o texto constitucional. Conforme as palavras do autor,

O sujeito constitucional, que emerge do encontro do eu com o outro, fundado na ausência e na alienação, encontra-se em uma posição que requer que ele esqueça a sua identidade utilizando-se do medium de um discurso constitucional, enraizado em uma linguagem comum que vincula e une o multifacetado $e u$ constitucional aos seus múltiplos outros ${ }^{545}$.

\footnotetext{
${ }^{545}$ ROSENFELD, Michel. Ibidem, pg. 23.
} 
Em seu estudo, a intersubjetividade já se põe como um elemento constitutivo da teoria constitucional, que também alcança a compreensão sobre o poder constituinte e sua relação com a legitimidade e o sentido de constituição. É preciso que a teoria do poder constituinte alcance, verdadeiramente, o sentido de intersubjetividade manifesto por Rosenfeld para que uma releitura total do direito constitucional possa ser empreendida, pois seus problemas tocam no âmago da tensão entre poder e ordem.

Uma das maiores dificuldades para a teoria do poder constituinte democrático é a percepção de que, em certo nível, a sociedade contemporânea é marcada por instabilidades e conflitos quanto ao próprio projeto de vida compartilhado que se impõe na forma de constituição. Por tal razão Neves desacredita na possibilidade de formação de consensos normativos nos moldes propostos por Habermas. Para Neves, o dissenso conteudístico é uma marca da esfera pública pluralista e cosmopolita, quando eticidades conflitantes e incompatíveis entre si são chamadas a dialogar na busca de decisões comuns. Como, então, legitimar uma constituição através de um ato fundamental de autodeterminação se esse ato não está amparado em um consenso generalizado?

A saída parece ser a radicalização da democracia num nível ainda mais profundo, assumida na forma de um "consenso procedimental”. A marca da organização democrática contemporânea é, portanto, a própria percepção de um consenso impossível, a percepção de que, embora as decisões precisem e sejam efetivamente tomadas, elas não representam o fechamento do processo decisório, que permanece, num canal de participação e diálogo contínuo, o qual está, constantemente, colocando à prova a decisão tomada e permitindo reavaliações. Reconhecer a impossibilidade de um consenso não é negar a razão dialogal, mas incorporar o procedimento de deliberação como o caminho através do qual ela se manifesta.

Igualmente problemático é o exercício do poder constituinte fora do estado, quando se pensa no progresso rumo a uma sociedade cosmopolita e global. Apesar de proclamada por Habermas como um avanço civilizatório, a sociedade política para além dos limites dos estados nacionais parece uma realidade ainda distante. Essa conclusão pode ser tomada quando se observa a experiência europeia em sua tentativa de unificação, questionável tanto no nível político como econômico. Como pontua o filósofo alemão, expectativas comerciais não constituem motivo capaz de levar a população a apoiar politicamente o 
projeto arriscado de uma união digna desse nome, é preciso pensar a união para além do econômico $^{546}$.

Não só as desigualdades sociais e econômicas continuaram existindo após a unificação, como ainda não se pôde perceber um senso compartilhado de pertença a uma comunidade continental, para além das diferenças culturais. A não aprovação da constituição europeia por alguns países e a crise econômica enfrentada pelas nações periféricas demonstram que a organização política na forma de estados nacionais ainda se impõe como opção fundamental do mundo europeu, dificultando a consolidação da união de estados.

Pensar como o poder constituinte pode ultrapassar as barreiras nacionais e se organizar de forma global é, também, um desafio teórico que merece atenção especial na continuidade dos estudos sobre o tema.

${ }^{546}$ HABERMAS, Jürgen. Era das transições, tradução de Flávio Siebeneichler. Rio de Janeiro: Tempo Brasileiro, 2003, pg. 127. 


\section{CONCLUSÃo}

Falar de poder constituinte, em especial no contexto de uma teoria propositiva sobre o exercício legítimo do poder político, envolve imensas dificuldades. A principal delas diz respeito à tensão exposta por Habermas entre o fático e o normativo, entre um ideal racional e o efetivo. O poder constituinte, e tantas teorias que se destinem a analisá-lo sob diferentes óticas (filosófica, política, sociológica, antropológica), não é facilmente identificável como objeto de estudo. As possibilidades de que o fático escape ao normativo são consideráveis, se se tiver em conta que o compromisso com a legitimidade não é, ainda, uma pauta comum entre os povos.

Apesar de árdua, a tarefa de investigar as possibilidades de exercício do poder legítimo, da institucionalização da razão pela democracia, é necessária (e urgente), quando se tem em mente que a ciência precisa não só dar conta da realidade, como conduzir um processo reflexivo que permita a superação das dificuldades e o progresso pela práxis.

Pensar o poder constituinte a partir de uma perspectiva propositiva é indagar sobre as condições ideais para o exercício da tarefa de elaborar as constituições, a partir de um determinado modelo de estado e de sociedade. Neste trabalho, o modelo indicado foi o estado de direito, ou, ainda, o estado de direito democrático tal como concebido pelo procedimentalismo. Assim sendo, à luz da democracia - que se apresenta como uma exigência racional - como o poder constituinte deve ser conduzido se pretender a legitimidade e a validade das normas por ele produzidas?

O caráter propositivo de uma teoria sobre o poder constituinte é manifesto, assim, no objetivo geral de precisar os limites, as condições e os resultados de um processo constituinte conduzido conforme a razão, uma razão que se põe como dialogal, comunicativa, estruturada a partir da intersubjetividade.

Para empreender essa tarefa teórica, foi preciso conciliar uma leitura do direito em conjunto com a filosofia. Se o poder constituinte é um conceito limítrofe - não se pode dizer que é apenas jurídico, ou sociológico, ou político - a análise teórica precisa ser igualmente capaz de dialogar com mais de um enfoque de análise. A proposta foi, então, 
compreender o constituinte a partir de um determinado paradigma de razão, relacionado, pela filosofia de Jürgen Habermas, a uma teoria normativa da democracia.

As indagações principais que permearam a investigação foram: como a teoria do poder constituinte, elaborada a partir de postulados clássicos e liberais, pode ser revista em face das transformações de pensamento operadas com o desenvolvimento da reflexão filosófica no século XX? Como a compreensão da sociedade pela filosofia pode auxiliar o direito a também iniciar um exercício de reanálise de seus dogmas principais, atualizando e transformando pontos que não mais satisfazem as demandas e os anseios do corpo de indivíduos submetidos ao império das leis?

Buscou-se construir um percurso argumentativo que se iniciou com a leitura das referências principais da teoria clássica do poder constituinte, indicando suas características e conceitos básicos. Não sendo satisfatória hoje, já que construída para dar conta de outro momento histórico, foi preciso empreender uma nova leitura. Para tanto, definiu-se uma perspectiva de análise que, foi, sobretudo, filosófica: como, após a reviravolta linguístico-pragmática, se pode entender a relação entre sociedade e estado, entender o próprio exercício do poder político? Como a descoberta do caráter dialogal da razão gera reflexos na forma de compreensão do direito e da ordem constitucional?

Inúmeras contribuições filosóficas buscaram compreender a totalidade de tais indagações e, dentre todas, optou-se pela proposta de Jürgen Habermas e sua tentativa de dar conta da difícil tensão (ou do aparente paradoxo) entre fato e norma. A visão de Habermas sobre a função do direito na democracia é útil para pensar o poder constituinte porque constitui uma proposta que pensa a origem do direito e suas potencialidades de forma instrumental: o direito pode servir de medium através do qual imperativos morais e pretensões normativas difundidas na sociedade podem encontrar força institucional.

Com Habermas é possível pensar o poder constituinte como um poder que se fundamenta na razão comunicativa. O poder constituinte se transforma, com a proposta habermasiana, em um poder comunicativo, que se legitima pelo procedimento de deliberação generalizado, nos moldes de uma democracia radical, onde todos os potenciais atingidos pela norma podem participar de sua discussão e imposição. Trata-se de uma forma inteiramente nova de pensar o poder constituinte, para além da tradicional dicotomia entre poder de fato e poder de direito. É, rigorosamente, uma manifestação da razão no exercício do poder político, um caminho através do qual o direito pode fundamentar-se, 
para além do aspecto formal, no que tange especificamente à elaboração da carta constitucional.

Assim sendo, a teoria propositiva do poder constituinte democrático é uma teoria que, apesar de pretender universalidade, pressupõe um determinado conceito de constituição forjado com o advento da modernidade. Ela reconhece a historicidade própria do poder enquanto manifestação cultural. É uma teoria apropriada para pensar o exercício do poder político na democracia, dentro da estrutura de um estado de direito, onde é preciso conciliar a soberania popular com a ideia de estado limitado em suas capacidades de ação.

Essa teorização sobre poder constituinte só se sustenta em face de alguns pressupostos filosóficos: a possibilidade de decisão racional sobre a validade de normas éticas; a incapacidade de determinação apriorística de conteúdos normativos bons em si mesmos; o fundamento de validade normativa como a observância de um procedimento de deliberação estruturado discursivamente, no qual todos os potenciais atingidos, em condições ideais de discurso, podem participar; a democracia como a institucionalização desse procedimento; a necessidade, para sobrevivência da democracia, da observância das condições necessárias ao exercício da razão no espaço político, entendida a partir da noção habermasiana de "direitos pressupostos".

Foi preciso reconstruir cada um dos pressupostos indicados, a fim de se reconhecer o poder constituinte a partir de novas bases. Entendido à luz da perspectiva clássica, o poder constituinte se apresenta como poder ilimitado, originário, autônomo e incondicionado, um poder "fora do direito", pré-estatal, a partir do qual se constitui a ordem jurídica em face de uma decisão política fundamental. Se entendido como puro, o poder constituinte é um poder total, absoluto, capaz de originar qualquer direito, seja quais forem os valores a serem protegidos. De acordo com esse olhar, o poder constituinte escapa mesmo a qualquer racionalização.

Para "racionalizar" o poder constituinte, foi preciso empreender algumas mudanças teóricas. Como sustentar a incondicionalidade em face do procedimento discursivo e inclusivo indispensável à fundamentação normativa? Como pensar a ilimitação material se existem condições necessárias para o exercício da democracia, por meio das quais se pode respeitar o espaço de liberdade individual e pensar a soberania popular como co-originária em relação a autonomia privada? Seria o poder constituinte inteiramente original e 
autônomo quando os processos constituintes se põem em estados já demarcados, com povo e território definidos? As características clássicas do poder constituinte não se sustentam, hoje, com exceção da identidade popular do titular da soberania, valor basilar das organizações democráticas.

Diante dos pressupostos expostos, é possível estabelecer uma proposta de teoria do poder constituinte democrático, que se define como uma teoria de direito positivo, concebida para limitar o poder quando exercido na democracia, e que entende o poder constituinte como poder comunicativo, isto é, um poder que é manifestação da razão e, portanto, pretende legitimidade.

Com base em tais delineamentos, estrutura-se a proposta teórica a partir de postulados gerais, que se pressupõem mutuamente na formação de uma totalidade organizada. Em primeiro lugar, apresentou-se o fundamento do poder constituinte, seguindo-se de seus limites, para, por fim, se identificar propriamente quem é o sujeito constituinte a as consequências dessa identidade para a experiência constitucional concreta.

Pela exposição apresentada no capítulo final, chega-se à conclusão fundamental de que o poder constituinte dos estados democráticos é um poder limitado, um poder que se fundamenta na escolha pela democracia como modelo de organização social e política e que, para ser capaz de perpetuar e reproduzir essa escolha, precisa ser exercido a partir de certas condições necessárias, insuperáveis.

O poder constituinte democrático, para não negar a si mesmo, precisa respeitar o espaço de autonomia individual, reconhecer a importância do gozo de uma vida plena, preservar uma esfera pública livre e pluralista, respeitar a proibição do retrocesso normativo, entender sua existência como uma latência permanente, além de garantir o direito mais básico para a sustentação da democracia, o direito de participação política, o qual precisa ser igualmente distribuído entre os sujeitos.

Estando na origem da formação da ordem jurídica, quando se evidenciam os seus fundamentos axiológicos, o poder constituinte - e, principalmente, a forma de compreendê-lo - tem reflexos em diversos aspectos da teoria constitucional, permitindo reanálises e reinterpretações, entre eles: a suposição de normas constitucionais inconstitucionais; os limites do poder de reforma à constituição; o direito adquirido em face de ordem constitucional superveniente; etc. 
Criam-se, com a proposta de releitura do poder constituinte, aportes teóricos originais que podem auxiliar o debate sobre a compreensão da constituição, da gênese das normas constitucionais e de suas consequências para a interpretação sistêmica do ordenamento jurídico como um todo.

Se existem limites ao poder constituinte, condições legítimas para o seu exercício, é plausível sustentar que, em casos de inobservância de tais pressupostos, o resultado do processo constituinte não será válido juridicamente, ainda que passe por um processo formal de ratificação popular. Normas constitucionais - mesmo aquelas postas pelo constituinte originário - seriam "inconstitucionais", no sentido de ilegítimas, porque estariam violando as condições necessárias para o exercício ideal do poder constituinte. Essa conclusão abre um leque de novos conflitos interpretativos que podem ser enfrentados pela jurisdição constitucional, ampliando a reflexão sobre a teoria constitucional e sobre as transformações no sentido de constituição.

A relevância da temática é evidente quando se pensa que a história constitucional do Ocidente desde a Modernidade é uma história de mudança. Constituições foram escritas e reescritas. Regimes autoritários foram substituídos por democracias marcadas pela instabilidade e pela busca de legitimidade. O tempo de vigência das cartas constitucionais mostra-se cada vez mais reduzido, quando a sociedade cresce em complexidade, em dimensão, e os problemas jurídicos ultrapassam as barreiras do direito doméstico.

A preocupação com o poder constituinte e sua análise não estão reduzidas, conforme salienta Preuss, à identificação de quem pode exatamente ser o criador da constituição de um estado, mas em tematizar o significado do poder constituinte para a força impositiva da constituição, sua imperatividade. No constitucionalismo moderno, a autoridade da constituição é originada de sua fonte popular, o que o vincula fortemente às organizações democráticas do poder. Uma exata compreensão sobre o poder constituinte é, em última análise, uma compreensão sobre o poder, o seu exercício, e a gênese dos sistemas jurídicos ${ }^{547}$.

\footnotetext{
${ }^{547}$ PREUSS, Ulrich K. The exercise of constituent power in Central and Eastern Europe. In: WALKER, Neil; LOUGHLIN, Martin. The Paradox of Constitutionalism: Constituent Power and Constitutional Form. Oxford: Oxford Press, 2007,pg, 212.
} 
$\mathrm{Na}$ democracia representativa, há que se reconhecer uma "distância" real que separa a comunidade política constitucional pluralista e os constituintes. O processo de elaboração da constituição, aponta Rosenfeld, é uma tentativa de preencher esse vazio, esse hiato, mediante o alcance do outro para forjar uma identidade comum enraizada em um texto constitucional compartilhado ${ }^{548}$.

O que um povo democrático pode efetivamente realizar, o caminho de seu desenvolvimento, são condicionados pelo êxito da elaboração originária da constituição. Estudar o poder constituinte é tentar, de algum modo, entender esse momento da história constitucional de um povo e orientá-lo conforme a razão para o diálogo.

${ }^{548}$ ROSENFELD, Michel. Ibidem, pg. 36. 


\section{REFERÊNCIAS BIBLIOGRÁFICAS}

APEL, K. O. Estudos de Moral Moderna, tradução de Benno Dischinger. Petrópolis: Vozes, 1994.

BARACHO, José Alfredo de Oliveira. Teoria Geral da Revisão Constitucional e Teoria da Constituição Originária. In Revista da Faculdade de Direito da UFMG, Belo Horizonte, v. 34, 1994.

BARroso, Luís Roberto. Curso de Direito Constitucional, $2^{\mathrm{a}}$ edição. São Paulo: Saraiva, 2010.

BARRUfINI, José Carlos Toseti. Revolução e Poder Constituinte. São Paulo: RT, 1976.

BERCOVICI, Gilberto. Constituição e Estado de Exceção Permanente: Atualidade de Weimar. Rio de Janeiro: Azougue Editorial, 2004.

. Constituição e Política: Uma relação difícil. In: Luanova, nº 61, 2004.

BITTAR, Eduardo C. B. Justiça e Emancipação: Reflexões Jusfilosóficas a partir do Pensamento de Jürgen Habermas. São Paulo: USP, 2011.

BLOTTA, Vitor S. L. Habermas e o Direito: Da Normatividade da Razão à Normatividade Jurídica. São Paulo: Quartier Latin, 2010. 
BOBBIO, Norberto. O positivismo jurídico: lições de filosofia do direito, tradução de Márcio Pugliesi et ali. São Paulo: Ícone, 2006.

BOBBIO, Norberto; MATTEUCCI, Nicola; PASQUINO, Gianfranco. Dicionário de

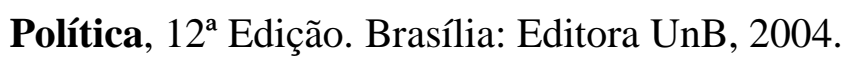

BONAVIDES, Paulo. Curso de Direito Constitucional. São Paulo: Malheiros, 2004.

BURDEAU, Georges. La conception du pouvoir selon la Constitution du 4 octobre 1958. In: Revue de Science Politique, 1959, v.9, n. I.

Traité de Science Politique. Paris: Librairie Génerale de Droit et Jurisprudence, 1966.

CANOTILHO, J. J. G. Direito Constitucional e Teoria da Constituição, $7^{\text {a }}$ ed. Coimbra: Almedina, 2003.

CAPPELlETTI, Mauro; GARTH, Bryant. Acesso à Justiça, tradução de Ellen Gracie Northfleet. Porto Alegre: SAFE, 1988.

CAYLA, Olivier; PASQUINO, Pasquale. Le pouvoir constituant et l'Europe. Paris: Dalloz, 2011.

COLÓN-RÍOS, Joel. I. Weak Constitutionalism: Democratic Legitimacy and the question of constituent power. New York: Routledge, 2012.

CORTINA, Adela. Ética sem moral, tradução de Marcos Marcionilo. São Paulo: Martins Fontes, 2010. 
COSTA, Regenaldo da. Ética do Discurso e Verdade em Apel. Belo Horizonte: Del Rey, 2002.

DALLMAYR, Fred. Para além da democracia fugidia: Algumas Reflexões Modernas e Pós-Modernas. In: SOUSA, Jessé. Democracia Hoje: Novos desafios para a teoria democrática contemporânea. Brasília: Editora UnB, 2001.

DINIZ, Márcio Augusto de Vasconcelos. O Princípio de Legitimidade do Poder no Direito Público Romano e sua Efetivação no Direito Público Moderno. Rio de Janeiro: Renovar, 2006.

DUARTE, Écio Oto Ramos. Teoria do Discurso e Correção Normativa do Direito: Aproximação à Metodologia Discursiva do Direito, 2a ed. São Paulo: Landy, 2010.

DUSO, Giuseppe (org.). O Poder: História da Filosofia Política Moderna. Petrópolis: Vozes, 2005.

FEBRES-CORDERO, Jaime Buenahora. Filosofia e Historia del Poder Constituyente, in: UNIVERSITAS, N. 80, 1986.

FERREIRA FILHO, Manoel Gonçalves. Direito Constitucional Comparado: I - O Poder Constituinte. São Paulo: Editora da Universidade de São Paulo, 1974.

FURET, François; OZOUF, Mona et ali. Dictionnaire critique de la révolution française: Institutions et Créations. Paris: Flammarion, 2007.

GONZALEZ E., Juan Jose; LAMOUNIER, Bolivar; MIRANDA, Jorge; NOHLEN, Dieter. El Proceso Constituyente: Experiencias a partir de cuatro casos recientes - España, 
Portugal, Brasil y Chile. In: Cadernos de Direito Constitucional e Ciência Política, São Paulo, Revista dos Tribunais, Ano 1, out./dez., 1992.

GOYARD-FABRE, Simone. Os Princípios Filosóficos do Direito Político Moderno, tradução de Irene Paternot. São Paulo: Martins Fontes, 1999.

GÖZLER, Kemal. Pouvoir constituant. Bursa: Editions Ekin Kibatevi, 1999.

HÄBERLE, Peter. Hermenêutica constitucional. A Sociedade aberta dos intérpretes da constituição: contribuição para a interpretação pluralista e procedimental da constituição, tradução de Gilmar Ferreira Mendes. Porto Alegre: SAFE, 1997.

HABERMAS, J. Direito e Democracia: ente facticidade e validade, v.I, tradução de Flávio Beno Siebeneichler, 2a edição. Rio de Janeiro: Tempo Brasileiro, 2012.

. Direito e Democracia: ente facticidade e validade, v.II, tradução de Flávio Beno Siebeneichler, 1a edição. Rio de Janeiro: Tempo Brasileiro, 2011.

Verdade e Justificação: Ensaios Filosóficos, tradução de Milton Mota. São Paulo: Loyola, 2004.

O conceito de dignidade humana e a utopia realista dos direitos humanos, in: HABERMAS, Jürgen. Sobre a Constituição da Europa, traduzido por Denilson Werle, Luiz Repa e Rúrion Melo. São Paulo: Editora UNESP, 2012, pg. 7-38.

- A crise da União Europeia à luz de uma constitucionalização do direito das gentes: Um ensaio sobre a constituição da Europa. In: HABERMAS, Jürgen. Sobre a Constituição da Europa, traduzido por Denilson Werle, Luiz Repa e Rúrion Melo. São Paulo: Editora Unesp, 2012, pgs. 39-106. 
A Ética da Discussão e a Questão da Verdade, tradução de Marcelo Cipolla. São Paulo: Martins Fontes, 2007.

- Consciência Moral e Agir Comunicativo, tradução de Guido de Almeida. Rio de Janeiro: Tempo Brasileiro, 2003.

. La esfera de lo público. In: DÍAZ, Francisco Galván (comp.). Touraine y

Habermas, Ensayos de teoría social. UP/UAM Azcapotzalco: México, 1986.

Mudança Estrutural da Esfera Pública. Rio de Janeiro: Tempo Brasileiro, 1984.

Era das transições, tradução de Flávio Siebeneichler. Rio de Janeiro:

Tempo Brasileiro, 2003.

HONNETH, Axel. A textura da justiça: sobre os limites do procedimentalismo contemporâneo, tradução de Emil Sobottka e Joana Ripoll. In: Civitas, Porto Alegre, v.9, n. 3, set.-dez./2009.

HORTA, Raul Machado. Direito Constitucional, 5a edição. Belo Horizonte: Del Rey, 2010.

JASMIN, M. G.; FERES JÚNIOR, J (coords.). História dos conceitos: dois momentos de um encontro intelectual. Rio de Janeiro: Edições Loyola e Editora PUC-Rio, 2006.

JAUME, Lucien. Constituent power in France: the revolution and its consequences. In: WALKER, Neil; LOUGHLIN, Martin (orgs). The paradox of constitutionalism: 
constituent power and constitutional form. Oxford: Oxford University Press, 2008, pg. $67-85$.

KALYVAS, Andreas. The Basic Norm and Democracy in Hans Kelsen's Legal and Political Theory. In: Philosophy and Social Criticism, v. 32, n. 5, 2006, pg. 573-599.

- Popular sovereignty, democracy, and the constituent power. Constellations v. 12, n. 1, 2005, pg. 223-244.

KANT, Immanuel. Crítica da Razão Pura, tradução e notas de Fernando Costa Mattos. Petrópolis: Vozes, 2012.

KELSEN, Hans. Teoria Pura do Direito, tradução de João Baptista Machado. São Paulo: Martins Fontes, 2006.

Teoria geral do direito e do estado, tradução de Luís Carlos Borges.

São Paulo: Martins Fontes, 2005.

KLEIN, Claude. Inexistence ou disparition du pouvoir constituant? In: CAYLA, Olivier; PASQUINO, Pasquale (direc.). Le pouvoir constituant et l'Europe. Paris: Dalloz, 2011, pg. $39-48$.

KROL, Heloísa da S. Limites Materiais ao Poder Constituinte Originário: Uma Releitura da Teoria Constitucional a partir da noção de Direitos Humanos Universais. In: Revista dos Tribunais, v. 96, n. 861, 2007, São Paulo.

LAQUIEZE, Alain. La réception de Sieyès par la doctrine publiciste française du XIXème et du XXème siècles. In: Revista Electrónica de Historia Constitucional, nº 6, 2005. 
LE PILLOUER, Arnaud. Reconstitution(s) du pouvoir constituant. In: CAYLA, Olivier; PASQUINO, Pasquale (direcs). Le pouvoir constituant et l'Europe. Paris: Dalloz, 2011, pg. 61-74.

LEBRUN, GÉRARD. Kant e o Fim da Metafísica, tradução de Carlos Moura. São Paulo: Martins Fontes, 2002.

LENOWITZ, Jeffrey. Why ratification: Constituent power and the unexamined procedure. In: CAYLA, Olivier; PASQUINO, Pasquale. Le pouvoir constituant et l'Europe (direc.). Paris: Dalloz, 2001, pg. 9-38.

LOCKE, John. Dois Tratados sobre o Governo, tradução de Julio Fisher. São Paulo: Martins Fontes, 2005.

LOUGHLIN, Martin. Foundations of Public Law. Oxford: Oxford Press, 2012.

Constituent power subverted: from english constitutional argument to british constitutional practice. In: WALKER, Neil; LOUGHLIN, Martin (orgs). The paradox of constitutionalism: constituent power and constitutional form. Oxford: Oxford University Press, 2008, pg. 27- 48.

MALBERG, Carré de. Teoría General del Estado. México: Faculdad de Derecho/UNAM, 2000.

MANNONI, Stefano. La Dottrina Costituzionale di Sieyès. In: Quaderni Fiorentini: Per la Storia del Pensiero Giuridico Moderno, n.29, Milano, 2000.

MAUS, Ingeborg. O direito e a política: teoria da democracia, tradução de Elisete Antoniuk e Martônio Mont’Alverne Barreto Lima. Belo Horizonte: Del Rey, 2009. 
MENDES, Gilmar; COELhO, I. M.; BRANCO, P. G. G. Curso de Direito Constitucional. São Paulo: Saraiva, 2012.

MIRANDA, Jorge. Manual de Direito Constitucional, T. II, $4^{\text {a }}$ ed. Coimbra: Coimbra Editora, 2000.

. Poder Constituinte. In: Revista de Direito Público, n. 80, São Paulo, RT, out./dez., 1986.

NEGRI, Antonio. Insurgencies: Constituent Power and the Modern State. Minneapolis: University of Minnesota Press, 1999.

NÉRY JÚNIOR, Nelson. Princípios do processo civil na Constituição Federal, $7^{\mathrm{a}}$ edição. São Paulo: RT, 2002.

NEVES, Marcelo. Transconstitucionalismo. São Paulo: Martins Fontes, 2009.

Entre Têmis e Leviatã: Uma relação difícil. São Paulo: Martins Fontes, 2008.

A Constituição Simbólica. São Paulo: Martins Fontes, 2007.

Do consenso ao dissenso: O Estado democrático de direito a partir e além de Habermas. In: SOUZA, Jessé (org.). Democracia Hoje: Novos Desafios para a Teoria Democrática Contemporânea. Brasília: Editora UnB, 2001. 
NEVES, Raphael; LUBENOW, Jorge. Entre promessas e desenganos: lutas sociais, esfera pública e direito. In: NOBRE, Marcos; TERRA, Ricardo (orgs.). Direito e Democracia: Um guia para leitura de Habermas. São Paulo: Malheiros, 2008.

NIETO, Alejandro. Crítica de la razón jurídica. Madrid: Editorial Trotta, 2007.

NOLTE, Detlef; SCHILLING-VACAFLOR, Almut. New Constitutionalism in Latin America: Promises and Practices. Surrey: Ashgate, 2012.

OLIVEIRA, M. A. Ética, Direito e Democracia. São Paulo: Paulus, 2010. . A Filosofia na Crise da Modernidade. São Paulo: Loyola, 2001.

A Reviravolta Linguístico-Pragmática na Filosofia Contemporânea. São Paulo: Loyola, 2006.

OLIVEIRA, Nythamar de. O Problema da Fundamentação Filosófica dos Direitos Humanos: Por um Cosmolitismo Semântico-Transcendental. In: Ética, Florianópolis, v. 5, n.1, pg. 21-31, jun. 2006.

PASQUINO, Pasquale. Emmanuel Sieyès, Benjamin Constant et le "gouvernement des modernes". Contribution à l'histoire du concept de répresentation politique. In: Revue Française de Science Politique, Ano 37, nº 2, 1987, pg. 214-229.

Sieyès et l'invention de la Constitution en France. Paris: Éditions Odile Jacob, 1998. 
Le pouvoir constituent, le gouvernement limité et ses origines dans le Nouveau Monde. In: CAYLA, Olivier; PASQUINO, Pasquale (direcs). Le pouvoir constituant et l'Europe. Paris: Dalloz, 2011, pg. 49-60.

PEDRON, Flávio Quinaud. A Teoria do Poder Constituinte Hoje: A Tese do Patriotismo Constitucional como das Antigas Tradições. In: Revista dos Tribunais, São Paulo, v. 98, n. 884, junho, 2009.

PERELMAN, Chaïm. Lógica Jurídica: Nova Retórica, tradução de Vergínia Pupl. São Paulo: Martins Fontes, 1998.

PIMENTEL, Carlos-Miguel. Du contrat social à la norme suprême: l'invention du pouvoir constituant. In: Jus Politicum: Autour de la notion de Constitution, n. 3, 2009, pg. 2. Disponível em: http://www.juspoliticum.com/Du-contrat-social-a-la-norme.html. Último acesso em 9/1/13.

PREUSS, Ulrich K. Constitutional Powermaking for the new polity: some deliberations on the relations between constituent power and the constitution. In: Cardozo Law Rev., $\mathrm{n}$. 14, 1992.

The exercise of constituent power in Central and Eastern Europe. In: WALKER, Neil; LOUGHLIN, Martin. The Paradox of Constitutionalism: Constituent Power and Constitutional Form. Oxford: Oxford Press, 2007, pg. 211-228.

REPA, Luiz Sérgio. Direito e Teoria da Ação Comunicativa . In: NOBRE, Marcos; TERRA, Ricardo (orgs.). Direito e Democracia: Um Guia de Leitura de Habermas. São Paulo: Malheiros, 2008. 
ROSENFELD, Michel. A Identidade do sujeito constitucional, tradução de Menelick de Carvalho Neto. Belo Horizonte: Del Rey, 2003.

ROUSSEAU, J.J. O Contrato Social, tradução de Antonio Danesi. São Paulo: Martins Fontes, 2001.

SÁCHICA, Luis Carlos. Esquema para uma teoria del poder constituyente, $2^{\mathrm{a}}$ edição. Bogotá: Têmis, 1985.

SALDANHA, Nelson. Formação da Teoria Constitucional, $2^{\text {a }}$ edição. Rio de Janeiro: Renovar, 2000.

. O Poder Constituinte. São Paulo: Revista dos Tribunais, 1986.

SAlGADO, Gisele M. O Poder Constituinte: Um Paralelo entre a Visão da Teoria Política Clássica e o Direito Positivo da Atualidade. In: Revista de Direito Constitucional e Internacional, São Paulo, RT, 2007, v 15, n.60.

SEN, Amartya. Desenvolvimento como liberdade, tradução de Laura Motta. São Paulo: Cia das Letras, 2000.

SCHMITT, Carl. O Guardião da Constituição, tradução de Geraldo de Carvalho. Belo Horizonte: Del Rey, 2007.

. Teoría de la Constitución. Madrid: Editorial Revista de Derecho Privado,

SIEYÈS, E. J. Qu'est-ce que le tiers état? Paris, 1789. 
SILVA, José Afonso da. Poder Constituinte e Poder Popular: Estudos sobre a Constituição. São Paulo: Malheiros, 2007.

SILVESTRINI, Gabriella. Religion naturelle, droit naturel et tolerance dans la "profession de foi du vicaire Savoyard”. In: Archives de Philosophie, Centre Sèvres, 2009, tome 72 , pgs. 31-54.

. Diritto naturale e volontà generale: il contrattualismo republicano di Jean-Jacques Rousseau. Torino: Claudiana, 2010.

. Le républicannisme de Rousseau mis en contexte: le cas de Genève. In: Les études philosophiques, n. 83, 2007, pg. 519-541.

. Rousseau, Pufendorf and the eighteenth-century natural law tradition. In: History of European ideas, n. 36, 2010, pg. 280-301.

SOUZA, Jessé. Patologias da Modernidade: Um diálogo entre Habermas e Weber. São Paulo: Anna Blume, 1997.

TAVARES, André Ramos. Reflexões sobre a Legitimidade e as Limitações do Poder Constituinte, da Assembleia Constituinte e da Competência Constitucional Reformadora. In: Cadernos de Direito Constitucional e Ciência Política, São Paulo, Revista dos Tribunais, n. 21, out./dez., 1997.

THOMPSON, John B. La teoría de la esfera publica. In: Voces y culturas, 10, 1996, pgs. 81-96.

VAZ, Henrique C. de Lima. Escritos de Filosofia II: Ética e Cultura, $4^{\text {a }}$ edição. São Paulo: Loyola, 2004. 
VILLAS-BOAS, O. Legalidade e Legitimidade no pensamento de Jürgen Habermas. In: NOBRE, Marcos; TERRA, Ricardo. Direito e Democracia: Um guia para leitura de Habermas. São Paulo: Malheiros, 2008, pg. 147-172.

VITAle, Denise V.; MELO, R. S. Política Deliberativa e Modelo Procedimental de Democracia. In: NOBRE, Marcos; TERRA, Ricardo. Direito e Democracia: Um guia para leitura de Habermas. São Paulo: Malheiros, 2008, pg. 223-248.

WACHOWICZ, Marcos. Poder Constituinte e Transição Constitucional. Curitiba: Juruá, 2000.

WALKER, Neil; LOUGHLIN, Martin. The Paradox of Constitutionalism: Constituent Power and Constitutional Form. Oxford: Oxford Press, 2007.

WHITE, Stephen K. Razão, Justiça e Modernidade: A Obra Recente de Jürgen Habermas, tradução de Márcio Pugliesi. São Paulo: Ícone, 1995. 
